UNIVERSIDADE DE SÃO PAULO

ESCOLA DE ENGENHARIA DE SÃO CARLOS

DEPARTAMENTO DE ENGENHARIA DE ESTRUTURAS

ULANA DE ANDRADE MEDINO

Estudo de um sistema de laje com fôrma de aço incorporada e conectores de cisalhamento nos apoios 



\title{
Estudo de um sistema de laje com fôrma de aço incorporada e conectores de cisalhamento nos apoios VERSÃO CORRIGIDA
}

A versão original encontra-se na Escola de Engenharia de São Carlos

\begin{abstract}
Dissertação apresentada ao Programa de PósGraduação em Engenharia Civil (Engenharia de Estruturas) da Escola de Engenharia de São Carlos da Universidade de São Paulo para obtenção do título de Mestre em Ciências.
\end{abstract}

Área de concentração: Estruturas

Orientador: Prof. Dr. Maximiliano Malite

São Carlos 
AUTORIZO A REPRODUÇÃO TOTAL OU PARCIAL DESTE TRABALHO, POR QUALQUER MEIO COONVENCIONAL OU ELETRÔNICO, PARA FINS DE ESTUDO E PESQUISA, DESDE QUE CITADA A FONTE.

Ficha catalográfica elaborada pela Biblioteca Prof. Dr. Sérgio Rodrigues Fontes da EESC/USP com os dados inseridos pelo(a) autor(a).

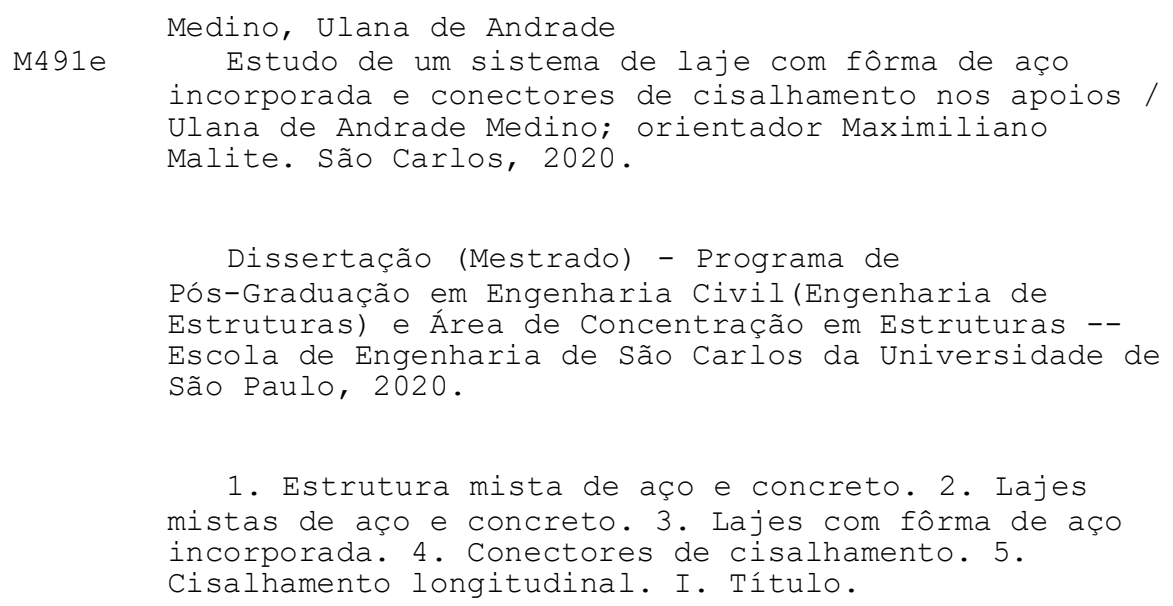

Eduardo Graziosi Silva - CRB - 8/8907 


\section{FOLHA DE JULGAMENTO}

Candidata: Engenheira ULANA DE ANDRADE MEDINO.

Título da dissertação: "Estudo de um sistema de laje com fôrma de aço incorporada e conectores de cisalhamento nos apoios".

Data da defesa: 25/03/2020

Comissão Julgadora

Prof. Titular Maximiliano Malife

(Orientador)

(Escola de Engenharia de São Carlos/EESC)

Profa. Dra. Silvana De Nardin

(Universidade Federal de São Carlos/UFSCar)

Prof. Dr. Ronaldo Rigobello

(Universidade Tecnológica Federal do Paraná/UTFPR)
Resultado

APROVADA 



\section{AGRADECIMENTOS}

À minha mãe Clenilde Andrade, por toda dedicação, coragem e sabedoria para lidar com as adversidades da vida e por todo sacrifício feito para que eu chegasse até aqui.

À minha irmã Yula Karla, por acreditar sempre no meu potencial e me incentivar, de todas as formas, a realizar esta etapa tão importante da minha vida.

Ao meu namorado, Paulo Henrique, pelo carinho, companheirismo e força para a realização deste trabalho.

Ao meu orientador Prof. Maximiliano Malite, pela orientação, paciência e dedicação no exercício de sua profissão.

À colega, Carol Rezende, pela parceria na realização do programa experimental e pelas orientações ao longo da pesquisa.

À Universidade Federal do Rio Grande do Norte pela minha formação acadêmica.

Aos professores José Neres e Fernanda Mittelbach pelo apoio, incentivo e inspiração para seguir a carreira acadêmica.

Aos funcionários, técnicos do laboratório e professores do Departamento de Estruturas da EESC que contribuiram para a realização deste trabalho.

À Coordenação de Aperfeiçoamento de Pessoal de Nível Superior (CAPES), pela concessão da bolsa de mestrado.

À empresa Modular Sistema Construtivo pela doação dos protótipos ensaiados. 

"Conhecer não é demonstrar nem explicar, é acender à visão"

(Antoine de Saint-Exupéry) 



\section{RESUMO}

MEDINO, U. A. Estudo de um sistema de laje com fôrma de aço incorporada e conectores de cisalhamento nos apoios. 2020. 151 p. Dissertação (Mestrado em Engenharia Civil (Estruturas)) Escola de Engenharia de São Carlos, Universidade de São Paulo, São Carlos, 2020.

As lajes mistas de aço e concreto apresentam como estado-limite último dominante o cisalhamento longitudinal, comum em lajes mistas com condição de interação parcial. Essas lajes são usualmente apoiadas em vigas de aço e conectadas a elas por meio de conectores de cisalhamento (em geral pinos com cabeça), constituindo as vigas mistas. Os conectores, embora usualmente desconsiderados no projeto das lajes, promovem aumento da capacidade resistente da interface aço-concreto e podem ser considerados conjuntamente com o sistema de mossas da fôrma para restrição ao deslizamento relativo após a ruptura da aderência. Neste trabalho foi desenvolvido um estudo teórico e experimental do comportamento estrutural de lajes mistas de aço-concreto com fôrma de aço incorporada e com conectores de cisalhamento do tipo pino com cabeça nos apoios, a fim de estudar a influência desses na resistência ao cisalhamento longitudinal da interface açoconcreto. A análise experimental consistiu nos ensaios de flexão de lajes mistas de duas séries de protótipos: oito simplesmente apoiados sem ancoragem de extremidade (série L) e dois simplesmente apoiados com conectores de cisalhamento nos apoios (série LC), o que permitiu avaliar a influência dos conectores no comportamento e na capacidade do sistema. A resistência ao cisalhamento longitudinal das lajes foi avaliada por meio da aplicação do método $m-k$ para as lajes sem conectores de cisalhamento, e método da interação parcial para as lajes com conectores. A partir dos resultados dos ensaios, pôde-se fazer uma análise comparativa do comportamento estrutural por meio das curvas força $\mathrm{x}$ flecha, força $\mathrm{x}$ deslizamento relativo de extremidade, força $\mathrm{x}$ deformação no aço e força $\mathrm{x}$ deformação no concreto; e da capacidade resistente das lajes mistas com conectores de cisalhamento, as quais apresentaram ductibilidade e resistência ao cisalhamento longitudinal consideravelmente maiores que as correspondentes lajes sem conectores.

Palavras-chave: Estrutura mista de aço e concreto. Lajes mistas de aço e concreto. Lajes com fôrma de aço incorporada. Conectores de cisalhamento. Cisalhamento longitudinal. 



\begin{abstract}
MEDINO, U. A. Study of a steel-concrete composite slab system with end anchorage supplied by shear connectors. 2020. 151 p. Dissertation (M. Sc. In Civil Engineering (Structures)) Department of Structural Engineering, School of Engineering of São Carlos, University of São Paulo, São Carlos, 2020.
\end{abstract}

The typical failure mode of steel-concrete composite slabs is the longitudinal shear, common in composite slabs with partial interaction condition. These slabs are currently supported on steel beams and connected to them by shear stud connectors, constituing the steel-concrete composite beams. The connectors, although not considered in the design of the slabs, promote an increase in the capacity of the steel-concrete interface and can be considered working together with the embossments of the profile to restrict the slip after de adhesion be ruptured. In this work, a theoretical and experimental study of the structural behavior of a slab with profiled steel decking with shear connectors in the supports was developed aiming to study their influence on the longitudinal shear strength at the steel-concrete interface. The experimental analysis comprised the flexure tests in two groups of specimens: eight simply-supported slabs non-anchored (group L) and two simply-supported slabs with shear connectors in the end supports (group LC), wich allowed to evaluate the contribuiton of the connectors to structural behavior and strength of the system. The longitudinal shear resistance of the slabs was calculated by applying the $\mathrm{m}-\mathrm{k}$ method for slabs without shear connectors, and the partial interation method for slabs with them. From the results obtained on the tests, it was possible to make a comparative analysis of the structural behavior considering load $\mathrm{x}$ midspan deflection curves, load x end-slip curves, load $\mathrm{x}$ steel strain curves and and load x concrete strain curves; and resistant capacity of the composite steel-concret slabs with shear connectors, wich presented higher ductibility and resistance to longitudinal shear than the corresponding non-anchored slabs.

Keywords: Steel and concrete composite structures. Steel and concrete composite slabs. Slabs with profiled steel decking. Shear connectors. Longitudinal shear. 



\title{
LISTA DE SÍMBOLOS E ABREVIATURAS
} \\ altura do bloco de compressão do concreto \\ Área da seção efetiva da fôrma correspondente a $b=1.000 \mathrm{~mm}$, determinada \\ desprezando-se a largura das mossas na seção transversal \\ Área da seção efetiva da fôrma correspondente a $b_{L}$ \\ Área da seção efetiva da fôrma correspondente a $B_{n}$ \\ Área da seção efetiva da fôrma de acordo com o EUROCODE 4 (2004) \\ Largura de $1.000 \mathrm{~mm}$ \\ Largura plana dos elementos da fôrma de aço \\ Largura da seção transversal da laje \\ Largura de uma nervura de uma laje mista \\ Distância da face superior da laje de concreto ao centro geométrico da seção efetiva \\ da fôrma de acordo com a ABNT NBR 8800 (2008) \\ Distância da face superior da laje de concreto ao centro geométrico da seção efetiva \\ da fôrma de acordo com o EUROCODE 4 (2004) \\ Distância do centro geométrico da área efetiva da fôrma de aço a sua face inferior \\ Módulo de elasticidade do aço da fôrma \\ Módulo de elasticidade secante do concreto \\ Módulo de deformação tangente inicial do concreto \\ Distância do centro geométrico da área efetiva da fôrma de aço a sua face inferior \\ correspondente a $B_{n}$ \\ Distância da linha neutra plástica da seção efetiva da fôrma a sua face inferior \\ Distância da linha neutra plástica da seção efetiva da forma a sua face inferior \\ correspondente a $B_{n}$ \\ F Força vertical aplicada pelo atuador \\ $f_{c} \quad$ Resistência à compressão média do concreto \\ Resistência à compressão de cálculo do concreto \\ $f_{c k} \quad$ Resistência à compressão característica do concreto
}




\begin{tabular}{|c|c|}
\hline $\mathrm{F}_{\text {des }}$ & $\begin{array}{l}\text { Força correspondente a um deslizamento relativo de extremidade de } 0,1 \mathrm{~mm} \text { em um } \\
\text { ensaio à flexão de laje mista }\end{array}$ \\
\hline $\mathrm{F}_{\max }$ & Maior valor de força alcançado num ensaio à flexão de laje mista \\
\hline$F_{\text {total }}$ & $\mathrm{F}_{\max }$ acrescida de $\mathrm{PP}_{\text {prot }}$ e $\mathrm{P}_{\text {disp }}$ \\
\hline$f_{\mathrm{uF}}$ & Resistência à ruptura média da fôrma de aço \\
\hline$f_{\mathrm{yF}}$ & Resistência ao escoamento média da fôrma de aço \\
\hline$f_{y F d}$ & Resistência ao escoamento de cálculo do aço da fôrma \\
\hline$f_{y F k}$ & Resistência ao escoamento característica do aço da fôrma \\
\hline$h_{t}$ & Altura total da laje \\
\hline$I_{m}$ & Momento de inércia médio da seção transversal de uma laje mista \\
\hline$k$ & Constante empírica determinadas a partir de dados experimentais (método $m-k$ ) \\
\hline$k_{5}$ e $k_{6}$ & $\begin{array}{l}\text { O mesmo que as constantes } \mathrm{m} \text { e } \mathrm{k} \text {, respectivamente de acordo com o CSSBI S2- } \\
2008\end{array}$ \\
\hline$L_{o}$ & Comprimento do balanço na extremidade do protótipo \\
\hline$L_{a}$ & $\begin{array}{l}\text { Parcela do vão de cisalhamento submetida à tensão de cisalhamento de ligação por } \\
\text { atrito na interface aço-concreto }\end{array}$ \\
\hline$L_{F}$ & $\begin{array}{l}\text { Vão teórico medido entre as linhas de centro dos apoios de uma laje mista na direção } \\
\text { das nervuras segundo a ABNT NBR } 8800 \text { (2008) }\end{array}$ \\
\hline$L_{m}$ & $\begin{array}{l}\text { Parcela do vão de cisalhamento submetida à tensão de cisalhamento de ligação } \\
\text { mecânica na interface aço-concreto }\end{array}$ \\
\hline$L_{S}$ & Vão de cisalhamento \\
\hline$L_{t}$ & Comprimento total de uma laje mista \\
\hline$L_{x}$ & Distância de uma seção transversal da laje mista ao apoio mais próximo \\
\hline$m$ & Constante empírica determinadas a partir de dados experimentais (método $m-k$ ) \\
\hline$M$ & Momento fletor \\
\hline$M_{\exp }$ & Momento fletor solicitante máximo obtido experimentalmente \\
\hline$M_{l, R m}$ & $\begin{array}{l}\text { Momento fletor resistente médio associado ao estado-limite último cisalhamento } \\
\text { longitudinal }\end{array}$ \\
\hline$M_{p a}$ & Momento de plastificação da fôrma de aço correspondente $a b=1.000 \mathrm{~mm}$ \\
\hline$M_{p a_{L}}$ & Momento de plastificação da fôrma de aço correspondente $a b_{L}$ \\
\hline$m_{p}$ & Constante semi-empírica do método $m-k$ de acordo com o ANSI/ASCE 3-91 (1992) \\
\hline
\end{tabular}


$M_{p r} \quad$ Momento de plastificação da fôrma de aço, reduzido pela presença da forca axial correspondente a $b=1.000 \mathrm{~mm}$

$M_{p R m} \quad$ Momento fletor resistente médio em interação completa

$M_{R d} \quad$ Momento fletor positivo resistente de cálculo

$M_{\text {test }} \quad$ Momento fletor associado ao cisalhamento longitudinal obtido experimentalmente

$N_{a} \quad$ Força normal resultante na fôrma de aço

$\bar{N}_{c} \quad$ Força normal de plastificação da capa de concreto de uma laje mista

$N_{c} \quad$ Força resultante normal na capa de concreto de uma laje mista em interação parcial

$N_{c f} \quad$ Força resultante Normal no concreto de uma laje mista em interação completa

$N_{p a} \quad$ Força normal de plastificação da fôrma de aço correspondente a $b=1.000 \mathrm{~mm}$

$N_{p a_{L}} \quad$ Força normal de plastificação da fôrma de aço correspondente a $b_{L}$

$P_{\text {disp }} \quad$ Peso próprio dos dispositivos de distribuição de força de um ensaio de flexão

$P P_{\text {prot }} \quad$ Peso próprio de um protótipo de laje mista

$R \quad$ Reação de apoio

$S \quad$ Desvio-padrão

$t_{a} \quad$ Altura da fôrma de aço

$t_{c} \quad$ Altura da laje de concreto acima do topo da fôrma de aço

$t_{F} \quad$ Espessura da fôrma de aço

$t_{n} \quad$ Espessura da fôrma de aço com o revestimento de zinco

$T_{p a} \quad$ Resultante de plastificação de tração na parte da fôrma de aço abaixo da linha de igual área

$V_{E d} \quad$ Força de cisalhamento máxima de projeto de acordo com o EUROCODE 4 (2004)

$V_{l, R d} \quad$ Força cortante resistente de cálculo associada ao estado-limite último cisalhamento longitudinal de acordo com a ABNT NBR 8800 (2008) e o EUROCODE 4 (2004)

$V_{l, R k} \quad$ Força cortante resistente característica associada ao estado-limite último cisalhamento longitudinal de acordo com a ABNT NBR 8800 (2008) e o EUROCODE 4 (2004)

$V_{l, R m} \quad$ Força cortante resistente média associada ao estado-limite último cisalhamento 1 ongitudinal de acordo com a ABNT NBR 8800 (2008) e o EUROCODE 4 (2004)

$V_{n} \quad$ Força cortante resistente característica associada ao estado-limite último cisalhamento longitudinal de acordo com o ANSI/ASCE 3-91 (1992) 
$V_{r} \quad$ Força cortante resistente de cálculo associada ao estado-limite último cisalhamento longitudinal de acordo com o CSSBI S2-2008 (2008)

$V_{t} \quad$ Forca cortante última associada ao estado-limite último de cisalhamento longitudinal obtida experimentalmente ou Força cortante resistente de cálculo associada ao estado-limite último cisalhamento longitudinal de acordo com o CSSBI S2-2008 (2008)

$\mathrm{X}$

$\mathrm{y}$

$y_{c g_{p a}}$

$\alpha$

$\beta_{c}$

$\delta$

$\delta_{\text {máx }}$

$\varepsilon_{a i}$

$\varepsilon_{a s}$

$\varepsilon_{e}$

$\gamma_{a l}$

$\gamma_{v s}$

$\mu$

$\eta$

$\varnothing$

$\rho_{a}$

$\tau_{u}$

$\tau_{u, m}$

Eixo das abscissas

Eixo das ordenadas ou distância vertical entre dois pontos

Altura do centro geométrico da parte da fôrma acima ou abaixo da linha de igual área em relação a essa mesma linha

Relação entre a largura da parte comprimida e a largura plana do elemento da fôrma de aço

Coeficiente de dilatação térmica do concreto

Deslocamento vertical

Deslocamento vertical máximo

Deformação longitudinal específica na onda baixa da fôrma de aço

Deformação longitudinal específica na onda alta da fôrma de aço

Deformação teórica correspondente ao início do escoamento da fôrma de aço

Coeficiente de ponderação do momento de plastificação da fôrma de aço

Coeficiente de seguranca para o estado-limite último cisalhamento longitudinal

Coeficiente de atrito entre o aço e o concreto

Grau de interação parcial ao cisalhamento

Coeficiente de ponderação das forças $V_{t}$ e $V_{n}$ ou bitola da armadura de retração

Taxa de aço referente à fôrma de aço

Tensão média resistente ao cisalhamento longitudinal na interface aço-concreto em interação parcial

Média aritmética de $\tau_{u}$ 
$\tau_{u, R d} \quad$ Tensão média resistente de cálculo ao cisalhamento longitudinal na interface açoconcreto

$\tau_{u, R k} \quad$ Tensão média resistente característica ao cisalhamento longitudinal na interface aço-concreto

$v_{\mathrm{c}} \quad$ Coeficiente de Poisson do concreto

ABNT Associação Brasileira de Normas Técnicas

ACI American Concret Institute

ANSI-ASCE American National Standards Institute - Society of Civil Engineers

ANSI-SDI American National Standards Institute - Steel Deck Institute

ASTM American Society for Testing and Materials

AWS American Welding Society

CSSBI Canadian Sheet Steel Building Institute 


\section{LISTA DE ILUSTRAÇÕES}

Figura 1. 1. Esboço da laje mista de aço e concreto. 28

Figura 1. 2. Outros meios de transferência de cisalhamento........................................................ 29

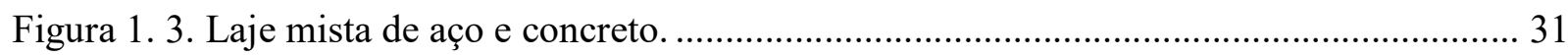

Figura 1. 4. Vista geral do ensaio de laje com fôrma de aço incorporada.................................... 32

Figura 2. 1. Mecanismos de ligação em lajes mistas de aço e concreto....................................... 35

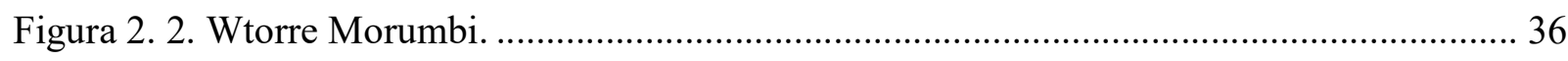

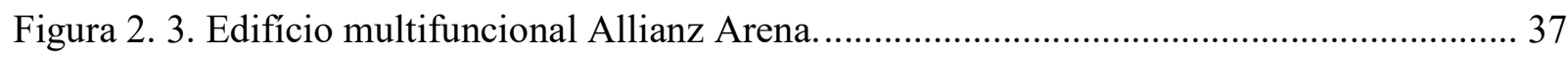

Figura 2. 4. Esquema geral do ensaio de lajes mistas................................................................ 43

Figura 2. 5. Ilustração da fissuração no concreto ao final do ensaio de flexão de lajes mistas..... 44

Figura 2. 6. Curva força $\mathrm{x}$ flecha das lajes mistas dúcteis............................................................ 44

Figura 2. 7. Distribuição de tensões de cisalhamento para lajes dúcteis em ensaios de flexão..... 45

Figura 2. 8. Curva força $\mathrm{x}$ flecha das lajes mistas frágeis. ............................................................. 46

Figura 3. 1. Seções críticas dos possíveis modos de colapso das lajes mistas. ............................. 48

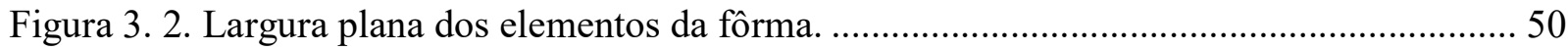

Figura 3. 3. Diagrama de tensões para momento positivo com linha neutra plástica acima da fôrma

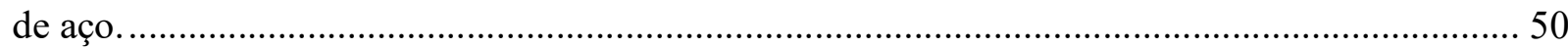

Figura 3. 4. Diagrama de tensões para momento positivo com linha neutra plástica na fôma de aço.

Figura 3. 5. Diagrama de interação entre a força axial e o momento na fôrma de aço. ................ 53

Figura 3. 6. Determinação experimental das constantes $\mathrm{m}$ e k..................................................... 57

Figura 3. 7. Distribuição das tensões normais para o método da interação parcial........................ 60

Figura 3. 8. Forças horizontais atuantes no concreto em uma determinada seção........................ 61

Figura 3. 9. Determinação gráfica do grau de interação parcial ao cisalhamento dos protótipos

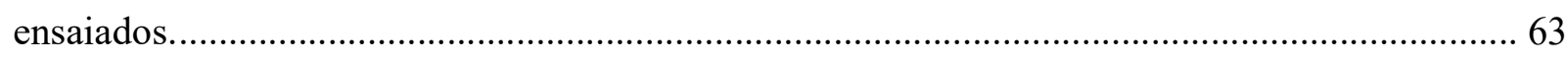

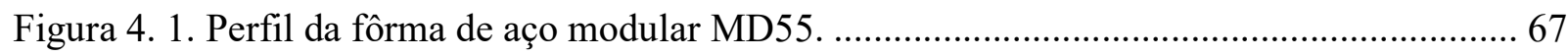

Figura 4. 2. Padrão de mossas do perfil da fôrma de aço modular MD55 .................................... 67

Figura 4. 3. Processo de soldagem do conector do tipo pino com cabeça sobre o perfil modular

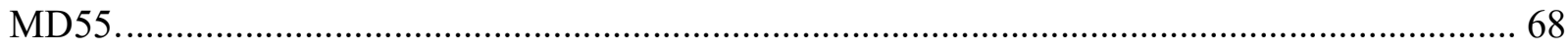

Figura 4. 4. Vista lateral e seção transversal dos protótipos da série L....................................... 71 
Figura 4. 5. Vista lateral e seção transversal dos protótipos da série LC.

Figura 4. 6. Transdutor de deslocamento para a medição do deslizamento relativo de extremidade.

Figura 4. 7. Transdutor de deslocamento para medição da flecha. .73

Figura 4. 8. Extensômetros elétricos uniaxiais na fôrma de aço (onda alta e onda baixa)............ 74

Figura 4. 9. Extensômetros elétricos uniaxiais na face superior da laje....................................... 74

Figura 4. 10. Posição dos extensômetros elétricos. ..................................................................... 75

Figura 4.11. Posição das seções S1, S2 e S3 na direção longitudinal da laje mista.........................75

Figura 4. 12. Vista geral do protótipo sem conectores de cisalhamento e aparato de ensaio........ 76

Figura 4. 13. Vista geral do protótipo com conectores de cisalhamento e aparato de ensaio....... 76

Figura 5. 1. Deslizamento relativo entre o concreto e a fôrma de aço na extremidade................. 81

Figura 5. 2. Aspecto da fissura na região da força aplicada após o deslizamento.......................... 82

Figura 5. 3. Fôrma descolada na lateral do protótipo MD55-L7 ................................................ 82

Figura 5. 4. Curva Força x Deslizamento Relativo do protótipo MD55-L2 . ............................... 83

Figura 5. 5. Curva Força x Deslizamento Relativo do protótipo MD55-L5 . ................................. 84

Figura 5. 6. Curvas Força $\mathrm{x}$ Flecha Experimental de todos os protótipo sem conectores de

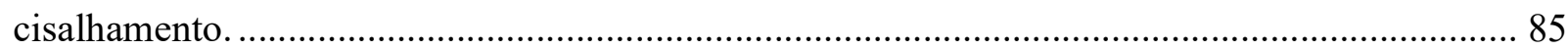

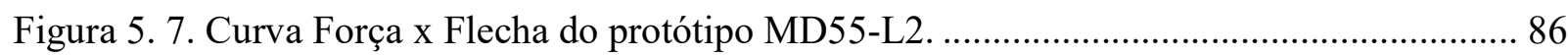

Figura 5. 8. Curva Força x Flecha do protótipo MD55-L5 ........................................................... 86

Figura 5. 9. Curvas Força x Deformação na fôrma de aço na seção S3 do protótipo MD55-L1. 88

Figura 5. 10. Curvas Força x Deformação no concreto na seção S1 do protótipo MD55-L1 ....... 89

Figura 5. 11. Curvas Força x Deformação na fôrma de aço na seção S1 do protótipo MD55-L5.89

Figura 5. 12. Curvas Força x Deformação na fôrma de aço na seção S1 do protótipo MD55-L5.90

Figura 5. 13. Curvas força $x$ deslizamento relativo dos protótipos MD55-L2 e MD55-LC1...... 92

Figura 5. 14. Curvas força $x$ deslizamento relativo dos protótipos MD55-L5 e MD55-LC2 ...... 93

Figura 5. 15. Curvas força $x$ flecha dos protótipos MD55-L2 e MD55-LC1................................ 94

Figura 5. 16. Curvas força $x$ flecha dos protótipos MD55-L5 e MD55-LC2 …........................... 94

Figura 5. 17. Curvas força x deformação na fôrma de aço dos protótipos MD55-L1 e MD55-LC1. 95

Figura 5. 18. Curvas força x deformação na fôrma de aço dos protótipos MD55-L5 e MD55-LC2. 
Figura 6. 1. Reta $\mathrm{m}-\mathrm{k}$ determinada com base em valores de projeto 99

Figura 6. 2. Dimensões, em mm, linearizadas de uma nervura do MD55. 101

Figura 6. 3. Perfil completo do MD55 linearizado com dimensões em mm 101

Figura 6. 4. Representação das forças que atuam em um trecho de comprimento $L_{x}$ a partir do apoio da laje mista. 106

Figura A. 1. Protótipos preparados para concretagem............................................................... 118

Figura A. 2. Concretagem dos protótipos. 118

Figura A. 3. Vista geral do ensaio: protótipo sem conectores de cisalhamento com vão teórico de $1.800 \mathrm{~mm}$

Figura A. 4. Vista geral do ensaio: protótipo sem conectores de cisalhamento com vão teórico de $3.600 \mathrm{~mm}$. 119

Figura A. 5. Vista geral do ensaio: protótipo com conectores de cisalhamento com vão teórico de $1.800 \mathrm{~mm}$ 120

Figura A. 6. Vista geral do ensaio: protótipo com conectores de cisalhamento com vão teórico de $3.600 \mathrm{~mm}$ 120

Figura A. 7. Detalhe do apoio fixo 121

Figura A. 8. Detalhe do apoio móvel. 121

Figura A. 9. Transdutor para medição do deslizamento relativo de extremidade. 122

Figura A. 10. Transdutor para medição da flecha. 122

Figura A. 11. Extensômetros eléticos na face superior da laje 123

Figura A. 12. Extensômetros elétricos uniaxiais na fôrma de aço (onda alta e onda baixa)....... 123

Figura A. 13. Aspecto típico da fissura na região da força aplicada, após o deslizamento......... 124

Figura A. 14. Deslizamento relativo entre o concreto e a fôrma de aço na extremidade............ 124

Figura C. 1. Curva Força x Deslizamento Relativo do protótipo MD55-L1............................... 128

Figura C. 2. Curva Força x Flecha do protótipo MD55-L2 ........................................................ 129

Figura C. 3. Curvas Força x Deformação no concreto na seção S1 do protótipo MD55-L1 ..... 129

Figura C. 4. Curvas Força x Deformação no concreto na seção S2 do protótipo MD55-L1 ..... 130

Figura C. 5. Curvas Força x Deformação no concreto na seção S3 do protótipo MD55-L1 ..... 130

Figura C. 6. Curvas Força x Deformação na fôrma de aço naa seção S1 do protótipo MD55-L1.

Figura C. 7. Curvas Força x deformação na fôrma de aço na seção S2 do protótipo MD55-L1. 131 
Figura C. 8. Curvas Força x Deformação na fôrma de aço na seção S3 do protótipo MD55-L1.132

Figura C. 9. Curva Força x Deslizamento relativo do protótipo MD55-L2 ................................ 133

Figura C. 10. Curva Força x Flecha do protótipo MD55-L2 .................................................... 133

Figura C. 11. Curva Força x Deslizamento relativo do protótipo MD55-L3 ............................... 134

Figura C. 12. Curva Força x Flecha do protótipo MD55-L3 ...................................................... 134

Figura C. 13. Curva Força x Flecha do protótipo MD55-L4.................................................... 135

Figura C. 14. Curva Força x Flecha do protótipo MD55-L4 ..................................................... 135

Figura C. 15. Curva Força x Deslizamento relativo do protótipo MD55-L5 .............................. 136

Figura C. 16. Curva Força x Flecha do protótipo MD55-L5.................................................... 136

Figura C. 17. Curvas Força x Deformação no concreto na seção S1 do protótipo MD55-L5 ... 137

Figura C. 18. Curvas Força x Deformação no concreto na seção S2 do protótipo MD55-L5. ... 137

Figura C. 19. Curvas Força x Deformação no concreto na seção S3 do protótipo MD55-L5 ... 138

Figura C. 20. Curvas Força x Deformação na fôrma de aço na seção S1 do protótipo MD55-L5.

Figura C. 21. Curvas Força x Deformação na fôrma de aço na seção S2 do protótipo MD55-L5.

Figura C. 22. Curvas Força x Deformação na fôrma de aço na seção S3 do protótipo MD55-L5.

Figura C. 23. Curva Força x Deslizamento Relativo do protótipo MD55-L6.............................. 140

Figura C. 24. Curva Força x Flecha do protótipo MD55-L6...................................................... 140

Figura C. 25. Curva Força x Delizamento Relativo do protótipo MD55-L7. .............................. 141

Figura C. 26. Curva Força x Flecha do protótipo MD55-L7 ...................................................... 141

Figura C. 27. Curva Força x Deslizamento Relativo do protótipo MD55-L8............................. 142

Figura C. 28. Curva Força x Flecha do protótipo MD55-L8 ...................................................... 142

Figura C. 29. Curva Força x Deslizamento Relativo do protótipo MD55-LC1 .......................... 143

Figura C. 30. Curva Força x Flecha do protótipo MD55-LC1 .................................................. 143

Figura C. 31. Curvas Força x Deformação no concreto na seção S1 do protótipo MD55-LC1.. 144

Figura C. 32. Curvas Força x Deformação no concreto na seção S2 do protótipo MD55-LC1.. 144

Figura C. 33. Curvas Força x Deformação no concreto na seção S3 do protótipo MD55-LC1.. 145

Figura C. 34. Curvas Força x Deformação na fôrma de aço na seção S1 do protótipo MD55-LC1. 
Figura C. 35. Curvas Força x Deformação na fôrma de aço na seção S2 do protótipo MD55-LC1.

Figura C. 36. Curvas Força x Deformação na fôrma de aço na seção S1 do protótipo MD55-LC1.

Figura C. 37. Curva Força x Deslizamento Relativo do protótipo MD55-LC2 ......................... 147

Figura C. 38. Curva Força x Flecha do protótipo MD55-LC2 .................................................. 147

Figura C. 39. Curvas Força x Deformação no concreto na seção S1 do protótipo MD55-LC2.. 148

Figura C. 40. Curvas Força x Deformação no concreto na seção S2 do protótipo MD55-LC2.. 148

Figura C. 41. Curvas Força x Deformação no concreto na seção S3 do protótipo MD55-LC2.. 149

Figura C. 42. Curvas Força x Deformação no fôrma de aço na seção S1 do protótipo MD55-LC2.

Figura C. 43. Curvas Força x Deformação no fôrma de aço na seção S2 do protótipo MD55-LC2. 150

Figura C. 44. Curvas Força x Deformação no fôrma de aço na seção S3 do protótipo MD55-LC2. 


\section{LISTA DE TABELAS}

Tabela 4. 1. Propriedades mecânicas do concreto de densidade normal de acordo com a ABNT NBR 8800 (2008)

Tabela 4. 2. Dimensões dos protótipos simplesmente apoiados sem conectores de cisalhamento.

Tabela 4. 3. Dimensões dos protótipos simplesmente apoiados com conectores de cisalhamento nos apoios. .70

Tabela 5. 1. Propriedades mecânicas do aço das fôrmas .................................................................. 78

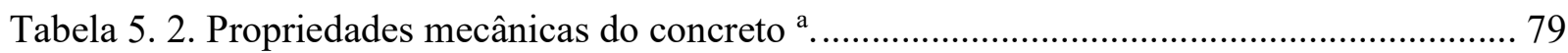

Tabela 5. 3. Resultados experimentais dos protótipos sem conectores de cisalhamento.............. 80

Tabela 5. 4. Resultados experimentais dos protótipos com conectores de cisalhamento.............. 91

Tabela 6. 1. Cálculo e análise estatística das constantes empíricas m e k (Unidades: N e mm). . 97 Tabela 6. 2. . Análise comparativa entre as forças cortantes experimentais (Vt) e as obtidas pelo

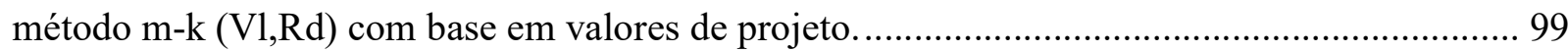

Tabela 6. 3. Momento fletor solicitante experimental versus momento fletor resistente............ 100

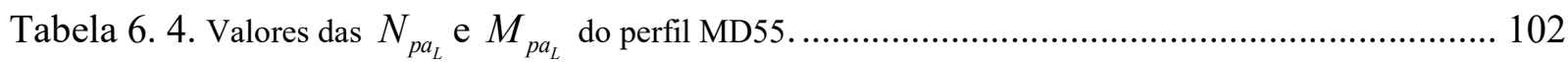

Tabela 6. 5. Valores da força normal no concreto para interação completa $(N c f)$ e do momento fletor correspondente à falha por cisalhamento longitudinal na seção de aplicação da força ..... 103 Tabela 6. 6. Análise comparativa entre as forças cortantes útimas experimentais (Vt) e as obtidas pelo método da interação parcial $\left(\mathrm{V}_{1, \mathrm{Rm}}\right)$. 107

Tabela 6. 7. Momento fletor solicitante experimental versus momento fletor resistente para interação total das lajes sem e com conectores de cisalhamento................................................ 108 Tabela 6. 8. Análise comparativa experimental e teórica da força cortante resistente................ 108 Tabela B. 1. Relações Força $(\mathrm{kN})$ x Flecha $(\mathrm{mm})$................................................................... 125 Tabela B. 2. Relações Força $(\mathrm{kN})$ x Deformação específica considerando o concreto tracionado fissurado. 125

Tabela B. 3. Relações Força $(\mathrm{kN})$ x Deformação específica considerando o concreto tracionado não fissurado. 126 


\section{SUMÁRIO}

1 INTRODUÇÃ

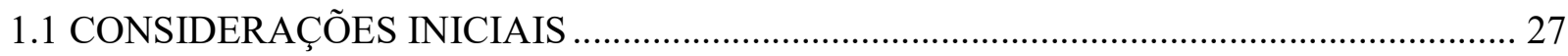

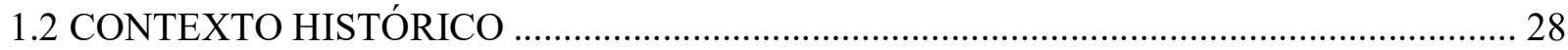

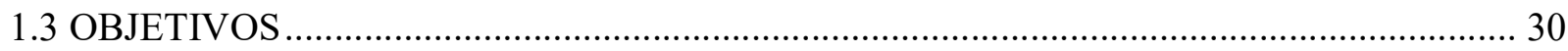

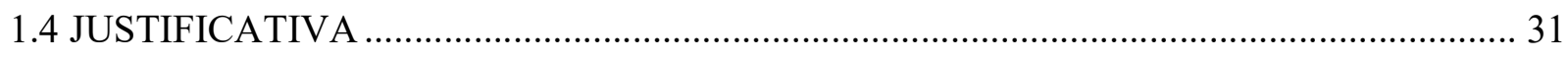

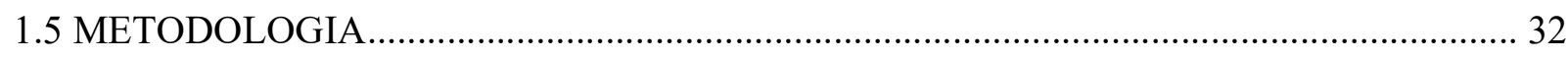

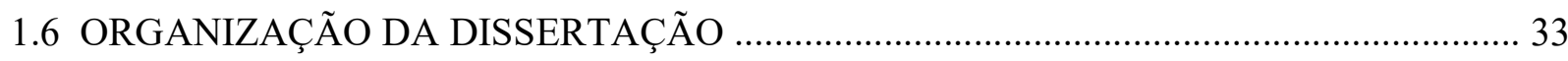

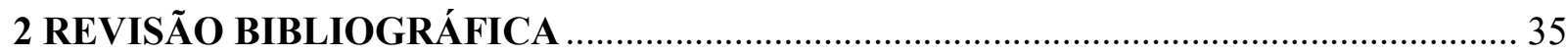

2.1 CONSIDERAÇÕES GERAIS SOBRE LAJES MISTAS ….............................................. 35

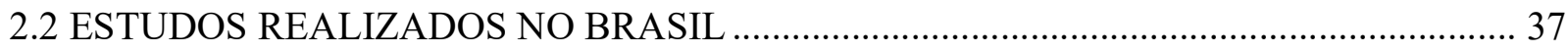

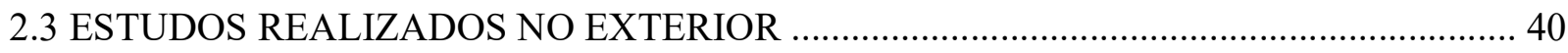

2.4 COMPORTAMENTO GERAL DAS LAJES MISTAS SOB FLEXÃO.............................. 42

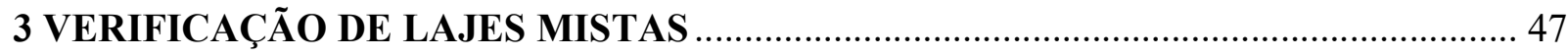

3.1 VERIFICAÇÃO DA FÔRMA DE AÇO: FASE INICIAL .................................................. 47

3.2 VERIFICAÇÃO DA LAJE MISTA NA FASE FINAL: ESTADOS-LIMITES ÚLTIMOS . 48

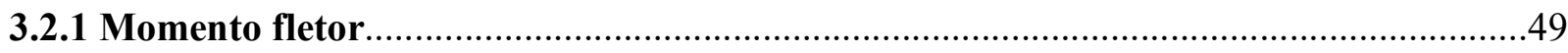

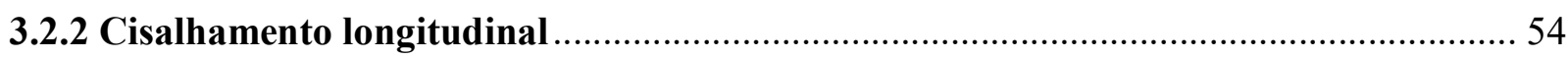

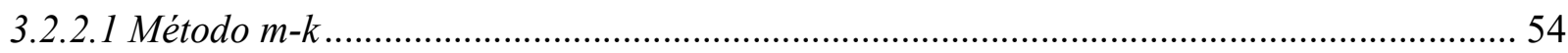

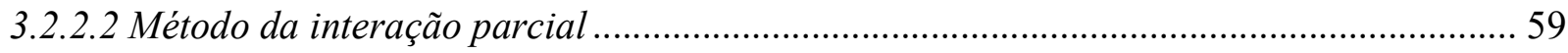

3.3 VERIFICAÇÃO DA LAJE NA FASE FINAL: ESTADO-LIMITE DE SERVIÇO............... 64

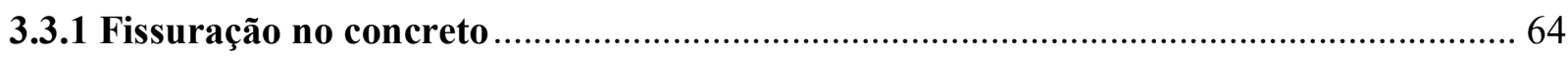


3.3.2 Deslocamento vertical. 64

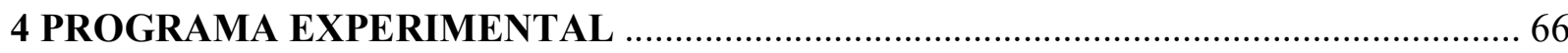

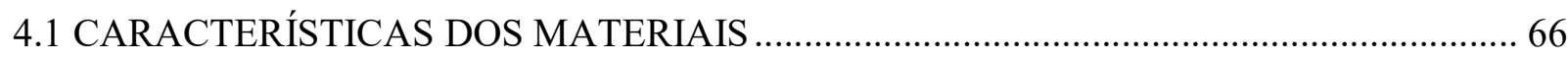

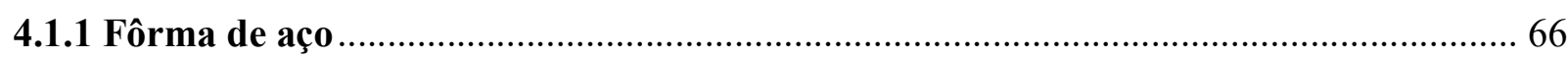

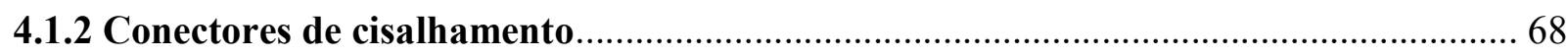

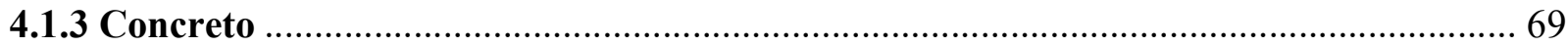

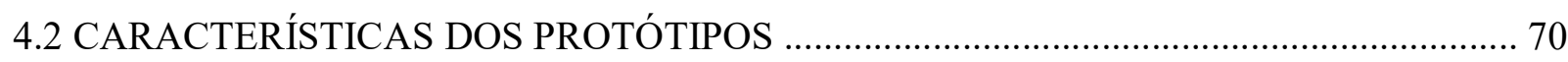

4.3 EQUIPAMENTOS DE ENSAIO E INSTRUMENTAÇÃO ............................................... 72

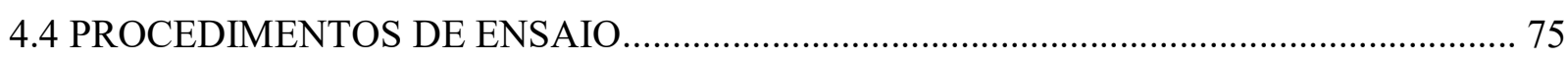

5 RESULTADOS EXPERIMENTAIS: INFLUENCIA DOS CONECTORES DE

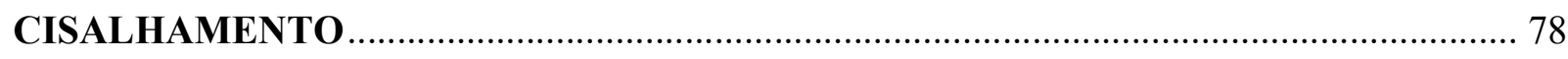

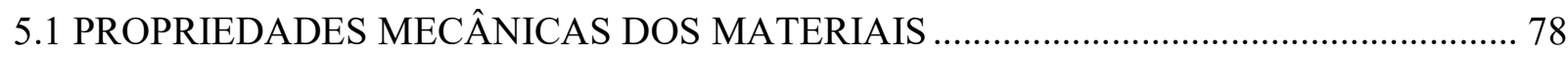

5.2 LAJES MISTAS SEM CONECTORES DE CISALHAMENTO ........................................ 80

5.3 LAJES MISTAS COM CONECTORES DE CISALHAMENTO ...................................... 91

5.4 INFLUÊNCIA DOS CONECTORES DE CISALHAMENTO NO COMPORTAMENTO DAS

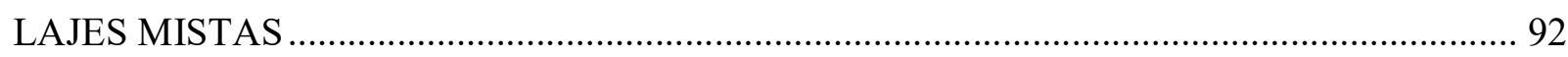

6 CÁLCULO DA RESISTÊNCIA AO CISALHAMENTO LONGITUDIAL ..................... 97

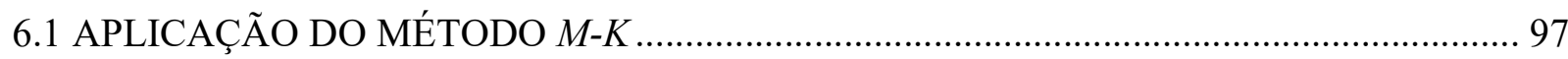

6.2 MOMENTO FLETOR RESISTENTE CORRESPONDENTE À INTERAÇÃO COMPLETA 100

6.3 APLICAÇÃO DO MÉTODO DA INTERAÇÃO PARCIAL …......................................... 100

6.4 INFLUÊNCIA DO CONECTOR DE CISALHAMENTO NA RESISTÊNCIA DE LAJES

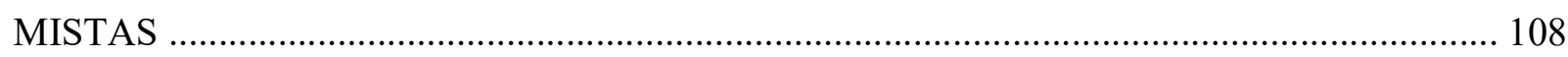

7 CONCLUSÕES E PROPOSTAS PARA TRABALHOS FUTUROS............................... 110

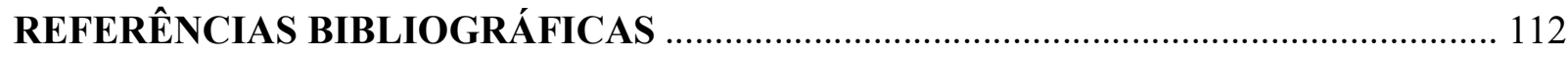

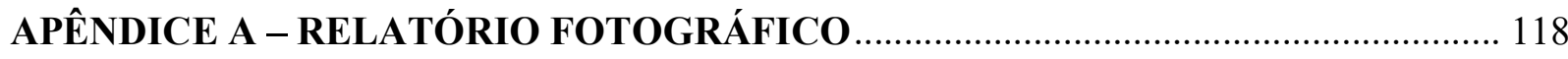


APÊNDICE B - CÁlCULO DOS DESLOCAMENTOS E DEFORMAÇÕES

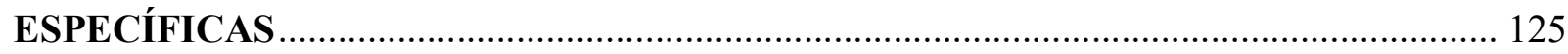

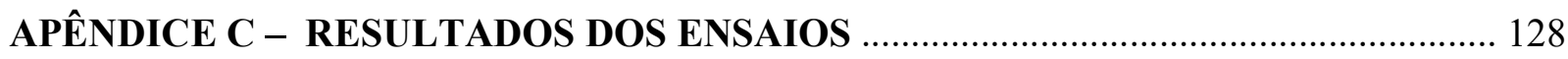

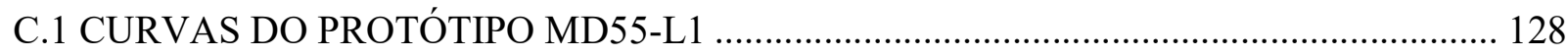

C.2 CURVAS DO PROTÓTIPO MD55-L2 _...................................................................... 133

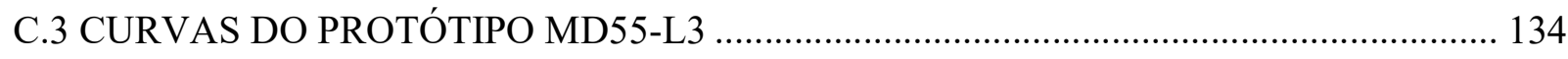

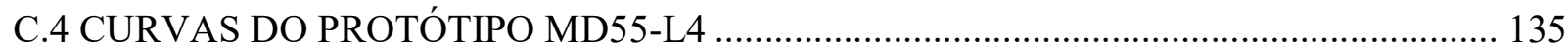

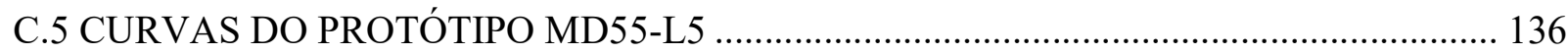

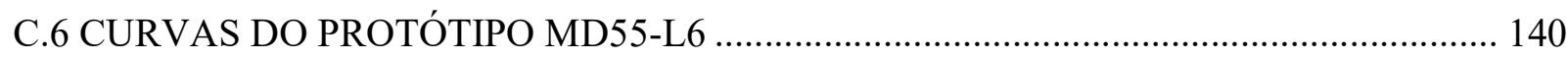

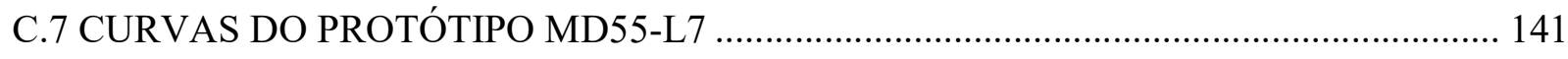

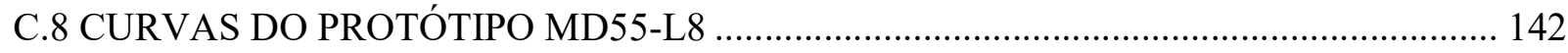

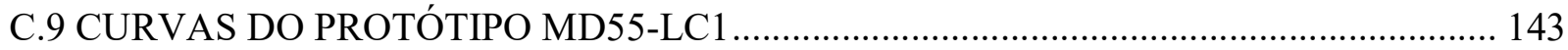

C.10 CURVAS DO PROTÓTIPO MD55-LC2 _.................................................................... 147 


\section{INTRODUÇÃO}

\subsection{CONSIDERAÇÕES INICIAIS}

Um elemento estrutural é considerado misto quando dois ou mais materiais trabalham de maneira solidária compondo a seção transversal. A distribuição dos esforços solicitantes que atuam numa seção qualquer de um elemento misto depende das propriedades mecânicas e da interação entre os materiais. Para o caso específico de sistema misto de aço e concreto, os elementos de aço trabalham em conjunto com o concreto formando elementos estruturais mistos tais como vigas, lajes, pilares ou ligações. Este tipo de estrutura apresenta um bom desempenho técnico e econômico e, por isso, tem sido bastante utilizada em diversos países.

Esta pesquisa aborda, em particular, o comportamento estrutural de lajes mistas de aço e concreto, também chamadas de lajes mistas com fôrma de aço incorporada. Segundo Pimenta e Mata (2001) as lajes mistas são elementos em que a fôrma de aço é incorporada ao sistema de sustentação das cargas, funcionando, antes da cura do concreto como suporte das ações permanentes e sobrecargas de construção e, depois da cura como parte ou toda armadura de tração da laje. Após o endurecimento do concreto, a fôrma de aço e o concreto passam a formar um único elemento estrutural, onde a fôrma, para garantir o comportamento misto do sistema, deve ser capaz de transmitir cisalhamento horizontal na interface entre os dois materiais.

A fôrma de aço, popularmente conhecida como steel deck®, consiste em uma fina chapa de aço zincada formada a frio sob a qual a laje de concreto armado é moldada, conforme o esboço geral apresentado na Figura 1.1. 
Figura 1. 1. Esboço da laje mista de aço e concreto.

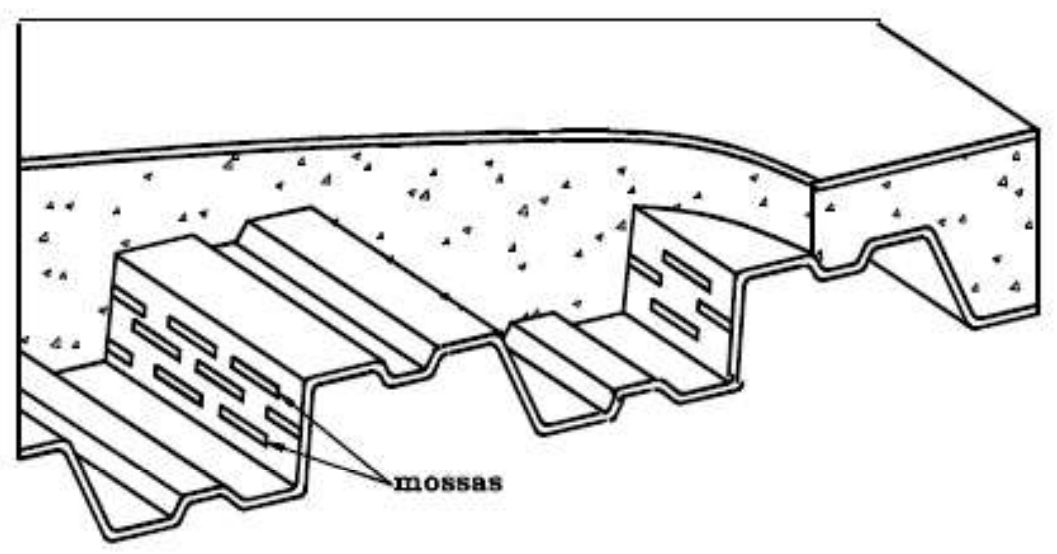

Fonte: Adaptado de ABNT NBR 8800 (2008)

A primeira norma brasileira a incluir o dimensionamento de estruturas mistas foi a ABNT NBR 8800: 1986, no ano de 1986. Atualmente, no Brasil, as normas vigentes para projeto de lajes mistas são: a ABNT NBR 8800 (2008) para o dimensionamento em temperatura ambiente e a ABNT NBR 14323 (2013) para a verificação em situação de incêndio. Para algumas prescrições de cálculo, a norma brasileira menciona diretamente as seguintes normas estrangeiras: EUROPEAN COMMITTEE FOR STANDARDIZATION - CEN EN 1994-1-1: 2004, AMERICAN NATIONAL STANDARDS INSTITUTE/AMERICAN SOCIETY OF CIVIL ENGINEERS ANSI/ASCE 3-91 (1992) e ainda, CANADIAN SHEET STEEL BUILDING INSTITUTE CSSBI S2-2008 (2008).

\subsection{CONTEXTO HISTÓRICO}

A utilização isolada do aço e do concreto com finalidade estrutural já havia se consolidado na construção civil desde a década de 1920. Os benefícios obtidos pela integração das propriedades desses dois materiais começaram a ser percebidos pelos engenheiros norte-americanos por volta de 1930.

Segundo Gomes (2001), na década de 1940 começam a surgir os sistemas de lajes mistas com fôrma de aço incorporada, quando pesquisadores americanos desenvolveram mecanismos 
capazes de transferir cisalhamento na interface aço-concreto. Assim, a fôrma de aço passou a atuar estruturalmente em conjunto com o concreto formando um elemento misto.

De acordo com Heagler (1993), a empresa Granco Steel Products Company, foi a primeira a desenvolver e apresentar uma laje mista em 1950, na qual o mecanismo de transferência de cisalhamento consistia em barras de aço soldadas nas nervuras da fôrma de aço, no entanto as empresas tiveram que encontrar outras soluções em função do alto custo de produção.

Durante a década de 1960 pesquisadores passaram a desenvolver outros meios de transferência de cisalhamento entre os dois materiais. Dessa maneira, surgiram as fôrmas de aço que apresentavam perfil trapezoidal ou reentrante, com pequenas saliências laterais, principalmente na alma, denominadas mossas, apresentadas na Figura 1.2b. Outra solução adotada pelos fabricantes foi inserir conectores do tipo stud nas extremidades das chapas (figura 1.2a).

Figura 1. 2. Outros meios de transferência de cisalhamento.

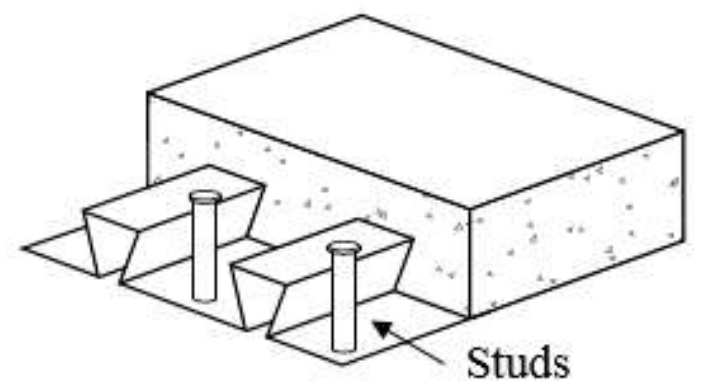

(a)

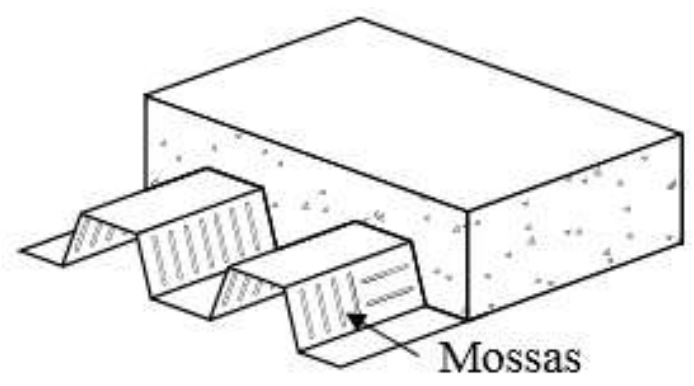

(b)

(a) Fôrma reentrante com conectores de cisalhamento; (b) Fôrma trapezoidal com mossas

Fonte: Grossi (2016)

Até a década de 1970 ainda não existia uma norma específica que tratasse do dimensionamento de lajes mistas. Schuster (1970) cita que as pesquisas sobre lajes com fôrma de aço incorporada eram resultado de pesquisas independentes de cada fabricante, de modo que cada um apresentava relatórios não publicados relativos ao comportamento e resistência de seus produtos em particular.

Nesse contexto, segundo Widjaja (1997), citado por Grossi (2016), as pesquisas que foram um marco para normatização das lajes mistas iniciaram em 1966 na Iowa State University, sob o patrocínio do AMERICAN IRON AND STEEL INSTITUTE - AISI, tais pesquisas serviram de base posteriormente para o AMERICAN SOCIETY OF CIVIL ENGINEER - ASCE (1992). 
Por volta década de 1980, o STEEL DECK INSTITUTE - SDI em conjunto com a West Virginia University desenvolveram estudos experimentais com a finalidade de investigar os efeitos da utilização de ancoragem de extremidade fornecida por conectores tipo pino com cabeça.

No contexto nacional, Tristão (2002) cita que, na década de 1950, o uso de estruturas mistas na construção civil limitou-se a poucos edifícios e pontes de pequeno porte e que as pesquisas sobre o tema em questão tiveram seu início no final da década de 1980.

\subsection{OBJETIVOS}

O trabalho proposto tem como objetivo principal a análise do comportamento estrutural de lajes mistas com fôrma de aço incorporada com conectores de cisalhamento.

Com o intuito de alcançar o objetivo principal descrito anteriormente, destacam-se os seguintes objetivos específicos:

- Avaliar a aplicabilidade dos métodos $m-k$ e da interação parcial para a determinação da resistência ao cisalhamento longitudinal;

- Avaliar a influência dos conectores de cisalhamento no comportamento e na resistência ao cisalhamento longitudinal dos protótipos. 


\subsection{JUSTIFICATIVA}

Os conectores de cisalhamento, em geral do tipo pino com cabeça, são utilizados para conectar as vigas de aço às lajes mistas, conforme ilustra a Figura 1.3, promovendo aumento da interação (entre a fôrma e o concreto) através da transferência de cisalhamento entre os materiais, e, consequentemente o aumento da resistência ao cisalhamento longitudinal da laje. A presença de tais conectores é uma exigência para a existência das vigas mistas

Figura 1. 3. Laje mista de aço e concreto.

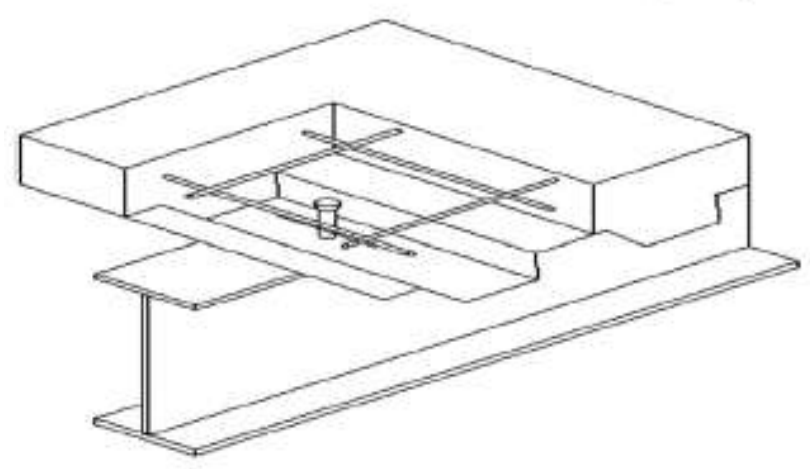

Fonte: Rana, Uy e Mirza (2015)

No caso de considerar esse aumento de resistência, a norma vigente para projeto de lajes mistas, a ABNT NBR 8800 (2008), não apresenta os critérios de cálculo que devem ser executados, ela apenas faz uma referência direta ao EUROPEAN COMMITTEE FOR STANDARDIZATION - EUROCODE 4 Parte 1-1: "A resistência ao cisalhamento longitudinal pode ser aumentada pela presença dos conectores de cisalhamento nas vigas de apoios das lajes [...] conforme prescrição do EUROCODE 4 parte 1-1.

A importância desta pesquisa consiste na contribuição com o avanço no estudo das lajes mistas de modo a proporcionar um aproveitamento mais racional dos materiais e consequentemente, economia, além de fornecer subsídios para elaboração de normas nacionais considerendo o aumento da resistência ao cisalhamento longitudinal devido à presença dos conectores nas extremidades das lajes. 


\subsection{METODOLOGIA}

A metodologia utilizada neste trabalho consiste na revisão bibliográfica, análise experimental e teórica de um sistema de laje com fôrma de aço incorporada.

A etapa da revisão bibliográfica consistiu no estudo das teorias já consolidadas sobre o comportamento e a resistência do sistema de lajes mistas, com ênfase nas pesquisas relacionadas ao estado limite último de cisalhamento longitudinal e no aumento da capacidade da interface aço-concreto devido à presença dos conectores de cisalhamento.

$\mathrm{Na}$ etapa experimental, foram realizados ensaios de flexão de lajes mistas em duas séries de protótipos: oito simplesmente apoiados sem ancoragem de extremidade (série L) e dois simplesmente apoiados com conectores de cisalhamento nos apoios (série LC), padronizados pelo EUROCODE 4 (2004), para a determinação da resistência ao cisalhamento longitudinal, conforme ilustrado na Figura 1.4. Com esta finalidade, as dimensões dos protótipos foram estabelecidas para a adequada aplicação do método $m$ - $k$. Além disso, com o objetivo de analisar o aumento de resistência ao cisalhamento devido à ancoragem de extremidade, foram ensaiados protótipos com e sem conectores de cisalhamento.

Figura 1. 4. Vista geral do ensaio de laje com fôrma de aço incorporada.

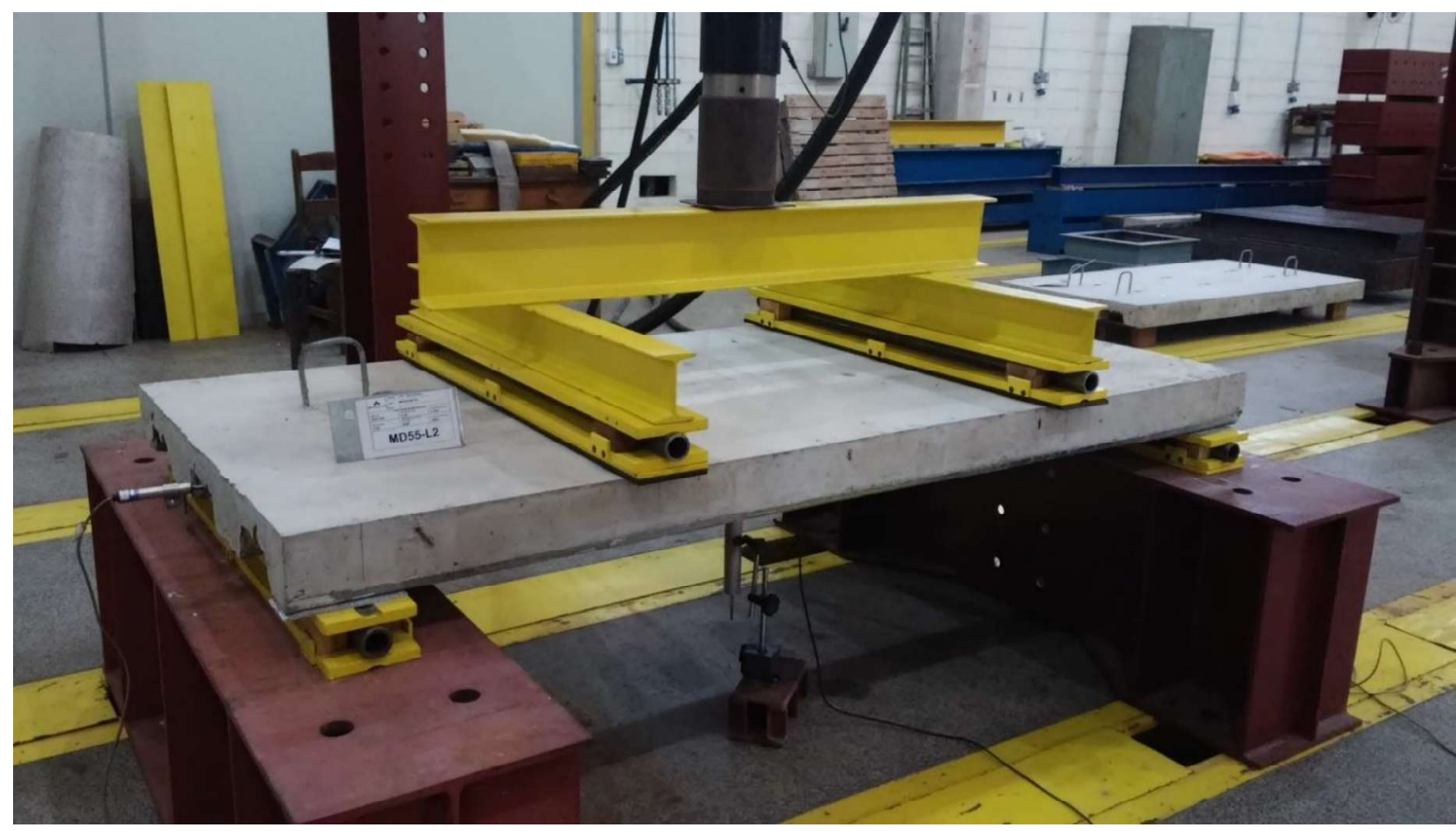

Fonte: Autora (2020) 
$\mathrm{Na}$ etapa de análise teórica foram aplicados os métodos já consolidados para o cálculo da resistência ao cisalhamento longitudinal $m-k$ e da interação parcial e realizada a análise do comportamento das lajes mistas com e sem conectores de cisalhamento por meio das curvas força $\mathrm{x}$ flecha, força $\mathrm{x}$ deslizamento relativo e força $\mathrm{x}$ deformação no aço. Por fim, uma análise comparativa foi realizada entre lajes com e sem conectores de cisalhamento para verificar a influência desses na capacidade resistente das lajes.

\subsection{ORGANIZAÇÃO DA DISSERTAÇÃO}

O texto foi organizado em sete capítulos, sendo neste primeiro capítulo descrito o contexto e um breve histórico do estudo das lajes mistas de aço e concreto. Além disso, são apresentados os objetivos, as justificativas e a metodologia da pesquisa.

O segundo capítulo apresenta uma revisão bibliográfica sobre os aspectos gerais das lajes mistas, bem como os estudos já consolidados sobre o comportamento desse tipo de sistema no âmbito nacional e internacional e a descrição do comportamento das lajes mistas sob flexão.

No terceiro capítulo discute-se o dimensionamento das lajes mistas de acordo com as prescrições da ABNT NBR 8800 (2008) e das normas estrangeiras por ela mencionadas, destacando-se a verificação da fôrma de aço na fase inicial, dos estados-limites últimos e de serviço na fase final.

O quarto capítulo apresenta o programa experimental, descrevendo as características dos materiais e dos protótipos, dos equipamentos utilizados, da instrumentação e do procedimento do ensaio de flexão de lajes mistas.

No quinto capítulo são apresentados os resultados provenientes dos ensaios e a análise o comportamento do sistema de lajes mistas com e sem conectores de cisalhamento do tipo pino com cabeça, nos apoios, por meio das curvas força $\mathrm{x}$ flecha, força $\mathrm{x}$ deslizamento relativo de extremidade, força x deformação no aço e força $\mathrm{x}$ deformação no concreto.

No sexto capítulo é exposto o procedimento de cálculo da resistência ao cisalhamento longitudinal das lajes sem ancoragem de extremidade pela aplicação do método $m-k$ e para as lajes com conectores de cisalhamento do método da interação parcial. Além disso, é apresentada a 
comparação entre os valores experimentais e teóricos obtidos para as séries de protótipos com e sem conectores.

Finalmente, no sétimo capítulo são feitas as considerações finais, levando em consideração a análise do comportamento e da resistência das lajes mistas com conectores de cisalhamento nos apoios e sugestões para pesquisas futuras. 


\section{REVISÃO BIBLIOGRÁFICA}

\subsection{CONSIDERAÇÕES GERAIS SOBRE LAJES MISTAS}

O sistema de lajes mistas de aço e concreto é definido pela ABNT NBR 8800 (2008) como aquele em que, na fase inicial, antes de o concreto atingir $75 \%$ da sua resistência à compressão, a fôrma de aço atua como suporte para todas as ações permanentes e sobrecargas de construção e, na fase final, o concreto atua estruturalmente em conjunto com a fôrma de aço, a qual funciona como parte ou toda a armadura de tração da laje

O comportamento das lajes de concreto com fôrma de aço incorporada é considerado misto quando a fôrma é capaz de transmitir o cisalhamento longitudinal na interface entre o aço e o concreto, o que pode ser obtido por meio da aderência natural entre os mateirais, da ligação mecânica que promove a restrição ao deslocamento relativo entre os materiais, como por exemplo a presença das mossas e por fim, a ligação por atrito devido à rugosidade superficial nos materiais.

ABNT NBR 8800 (2008) não permite a consideração efetiva da aderência natural entre o aço e o concreto para o comportamento misto do sistema de laje mista, sugerindo os seguintes meios para garantir a transmissão do cisalhamento longitudinal na interface aço-concreto: ligação mecânica por meio de mossas nas fôrmas de aço trapezoidais e ligação por meio de atrito devido ao confinamento do concreto nas fôrmas de aço reentrantes. Tais mecanismos são apresentados na Figura 2.1.

Figura 2. 1. Mecanismos de ligação em lajes mistas de aço e concreto.
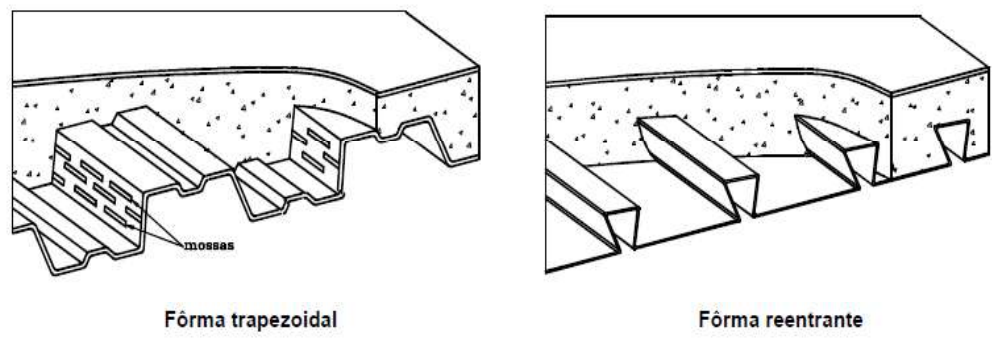

Fonte: ABNT NBR 8800 (2008) 
Entre as vantagens da utilização das lajes mistas destacam-se: dispensa de escoramento; redução de desperdício do material; facilidade de instalação e maior rapidez construtiva; redução ou mesmo eliminação da armadura de tração na região de momentos positivos; maior segurança do trabalho, por funcionar como plataforma de serviço e de proteção aos operários que trabalham nos andares inferiores em caso de colapso progressivo na etapa construtiva; praticidade de execução, uma vez que a fôrma fica incorporada ao sistema, não havendo a etapa de desfôrma; e sustentabilidade, com menor geração de resíduos.

Devido às vantagens apresentadas, a adesão às lajes mistas pela construção civil brasileira é notável, sendo encontradas em edifícios de múltiplos andares comerciais, residenciais, institucionais, hospitais, shopping centers, etc. As Figuras 2.2 e 2.3 apresentam exemplos de construções brasileiras que utilizaram esse tipo de sistema.

Figura 2. 2. Wtorre Morumbi.
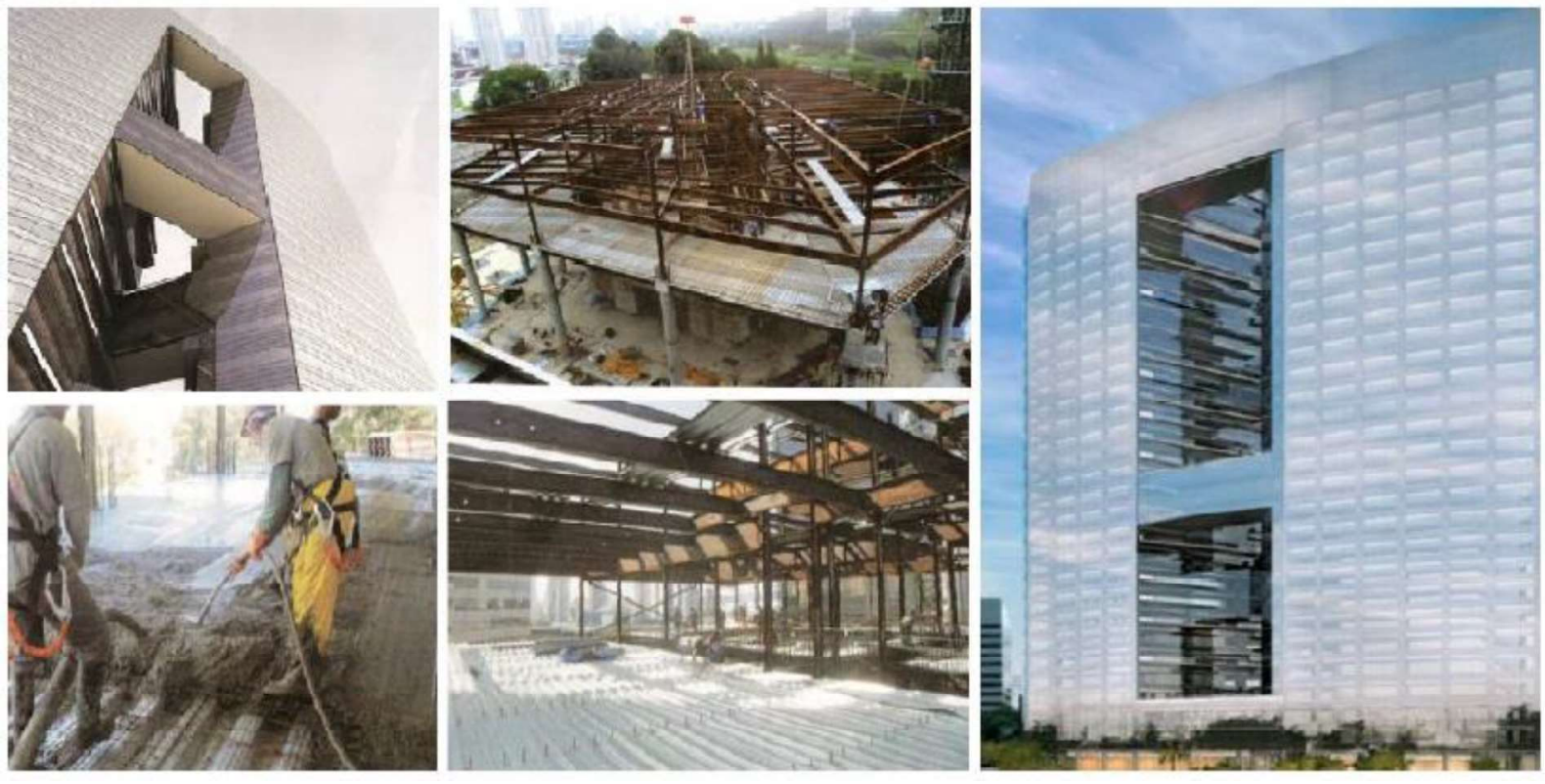

Fonte: Dias (2014) 
Figura 2. 3. Edifício multifuncional Allianz Arena.
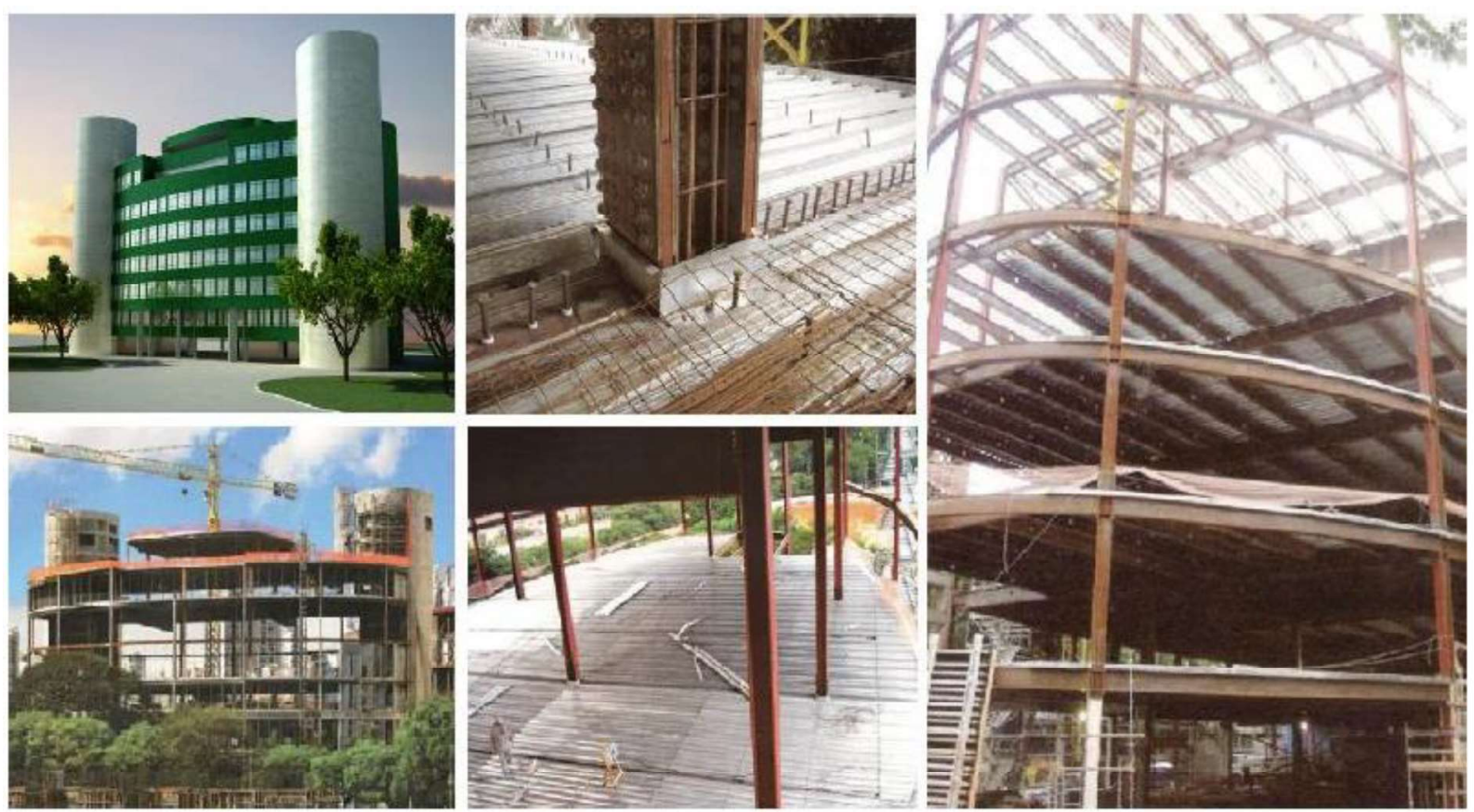

Fonte: Dias (2014)

As limitações do uso das lajes mistas estão relacionadas com razões estéticas, devido à necessidade de utilização de forros suspensos; maior quantidade de vigas secundárias, devido à limitação dos vãos antes da cura do concreto, caso não se utilize o sistema escorado e/ou fôrmas de grande altura; e risco de colapso da fôrma quando não há proteção adequada contra incêndio

\subsection{ESTUDOS REALIZADOS NO BRASIL}

No âmbito nacional, diversas pesquisas sobre as lajes de concreto com fôrma de aço incorporada têm sido realizadas.

Na universidade Federal de Minas Gerais (UFMG) foram feitos estudos relacionados ao comportamento e a resistência do sistema de lajes mistas. Melo (1999) estudou lajes mistas aplicadas a edifícios metálicos, com diferentes combinações de altura, vão de cisalhamento e espessura de fôrma de aço com o objetivo de identificar e avaliar os parâmetors que influenciam o comportamento e resistência desse tipo de sistema. Os resultados destes ensaios mostraram que o 
modo de colapso de todos os protótipos foi por cisalhamento longitudinal e foram estabelecidos critérios para a determinação da resistência ao cisalhamento longitudinal por meio da aplicação do método $m-k$ e interação parcial.

Silva (1999) complementou o trabalho de Melo (1999) com o objetivo de analisar o aspecto construtivo, o comportamento e a resistência do sistema de laje mista aplicado a estruturas prediais em concreto armado. Os resultados mostraram que a aplicação em estruturas convencionais de concreto armado apresenta comportamento equivalente ao verificado nas estruturas metálicas no que se refere ao modo de colapso, na capacidade de carga e nos parâmetros relativos ao estado-limite de utilização.

Campos (2001) avaliou o efeito da continuidade no comportamento e na resistência das lajes mistas. O estudo revelou um aumento significativo na capacidade portante da laje em relação aos protótipos simplesmente apoiados. No mesmo ano, a pesquisa de Gomes (2001) abordou o emprego do concreto estrutural leve em substituição ao concreto convencional, cujos resultados obtidos demonstraram ser semelhantes aos apresentados pelas lajes mistas confeccionadas com concreto convencional.

Souza Neto (2001) analisou o comportamento e a resistência de um sistema de lajes mistas com ancoragem de extremidade por meio de conectores do tipo pino com cabeça. Além disso, foi analisada a influência do atrito nos apoios na capacidade resistente da laje. Os resultados apresentados revelaram que as lajes mistas com ancoragem de extremidade demostraram um aumento significativo na rigidez e na resistência ao cisalhamento longitudinal com relação às lajes não ancoradas. $\mathrm{O}$ aumento do número de conectores de cisalhamento ocasionou um acréscimo na capacidade de carga dependendo das dimensões do protótipo, mas não houve mudança no modo de ruína que continuou sendo por cisalhamento longitudinal.

Costa (2009) também pesquisou sobre a consideração da influência do atrito dos apoios incluindo a avaliação do momento de inércia efetivo. Os resultados mostraram que as propostas apresentadas para o cálculo do momento de inércia efetivo representam melhor a rigidez das lajes mistas, tanto para o comportamento dúctil quanto frágil e, também, que a influência do atrito na resistência ao cisalhamento longitudinal é relevante, principalmente, em lajes mistas com pequenos vãos de cisalhamento.

$\mathrm{Na}$ Pontifícia Universidade Católica do Rio de Janeiro (Puc-Rio) também foram desenvolvidas pesquisas sobre lajes mistas a partir de 2001. A primeira delas foi realizada por 
Takey (2001) que estudou um novo sistema de laje mista com o uso de perfis metálicos de chapa dobrada e isopor sequencialmente dispostos lado a lado e preenchidos com concreto de armado. Os resultados obtidos indicaram que os custos do novo sistema de laje são equivalentes aos outros métodos de construção de lajes, mas que outras características como o tempo e as perdas economizadas na fase construtiva viabilizam a utilização do novo sistema. Avaliando um sistema de laje mista com perfis "C" enrijecidos e preenchidos com concreto estrutural, Vieira (2003) deu continuidade ao trabalho de Takey (2001). Os resultados dos ensaios revelaram a viabilidade estrutural deste tipo de sistema.

Beltrão (2003) realizou o estudo de um sistema de laje mista com o uso de perfis metálicos de chapa dobrada com corrugações na alma e chapa de vedação lateral. Os objetivos dos testes experimentais foram comprovar os resultados teóricos e fazer uma comparação com o sistema de laje proposto por Takey (2001). Os resultados apresentaram uma boa correlação com valores encontrados na literatura.

Com o objetivo de desenvolver uma geometria de perfil metálico que apresentasse uma melhor aderência na interface aço-concreto e com características de comportamento dúctil, Viana (2005) estudou várias formas de seção transversal ideal variando o peso, altura, espessura, resistência ao escoamento, vão máximo e capacidade de suporte de carga.O sistema construtivo proposto nesta pesquisa apresentou maior eficiência em relação aos propostos por Takey (2001) e Beltrão (2003) no que diz respeito a economia de tempo, além de rigidez 15\% maior.

A Universidade de São Paulo (USP) também tem desenvolvido várias linhas de pesquisas sobre este tema. Alva (2000) apresentou uma abordagem abrangente das estruturas mistas de aço e concreto com ênfase em edifífios. Foram abordados os aspectos construtivos, o comportamento estrutural e os procedimentos para dimensionamento recomendados pelo AISC e o EUROCODE 4. Além disso, foi analisado o projeto em situação de incêndio. Friedrich (2012) desenvolveu uma geometria de fôrma de aço trapezoidal para pisos mistos de pequena altura. A Geometria da fôrma e das mossas apresentaram um bom comportamento frente aos esforços cisalhantes com resistências comparáveis às fôrmas comercializadas.

Santos (2014) avaliou o comportamento térmico, estrutural e termoestrutural acoplado de um sistema de laje mista por meio de elementos finitos. No mesmo ano, Cordeiro (2014) analisou o comportamento de membrana de tração a altas temperaturas, uma vez que usando a teoria de placas para grandes deslocamentos, a pesquisa estabeleceu que as altas temperaturas podem induzir 
uma considerável ação de membrana de tração, o que auxilia na segurança da laje em situação de incêndio.

Sieg (2015) tratou do estudo de um novo perfil metálico a ser empregado como fôrma em lajes mistas. A autora analisou o perfil isolado de modo a identificar os modos de instabilidade e os respectivos esforços créticos referentes à fase de construção e também realizou uma análise experimental por meio do ensio de flexão padronizado pelo EUROCODE 4 com o objetivo de avaliar a resistência ao cisalhamento longitudinal através do método $m-k$.

Grossi (2016) investigou o comportamento estrutural de lajes mistas com armadura adicional por meio de uma extensão matemática das formulações já existentes para o caso sem armadura. Esta pesquisa propôs os critérios de dimensionamento para os estados-limites últimos (momento fletor e cisalhamento longitudinal) e de serviço (deslocamento vertical).

Morais Oliveira (2019) realizou o estudo do comportamento em serviço de lajes mistas de aço e concreto, com ênfase nos deslocamentos verticais diferidos no tempo, considerando os efeitos da retração e da fluência do concreto, além da interação entre o perfil de aço e o concreto. Os valores previstos por diferentes abordagens de avaliação apresentaram boa acurácia, destacando a importância da consideração dos efeitos dependentes do tempo na previsão dos deslocamentos verticais das lajes estudadas.

\subsection{ESTUDOS REALIZADOS NO EXTERIOR}

Segundo Melo (1999), a primeira publicação relevante sobre lajes mistas foi feita por Friberg em 1954, fornecendo uma visão geral do comportamento do perfil testado, além de apresentar uma comparação de custos entre os sistemas de lajes mistas e convencionais. Desde então, uma extensa linha de pesquisa sobre o tema tem sido desenvolvida. No presente tópico, este trabalho apresenta alguns estudos mais recentes sobre o comportamento e resistência das lajes mistas, com ênfase no estudo da influência dos conectores de cisalhamento.

O estudo realizado por Chen (2003) teve como objetivo identificar a ação do cisalhamento longitudinal nas lajes mistas por meio da análise experimental de sete protótipos de lajes mistas simplesmente apoiadas e duas contínuas. Diferentes tipos de ancoragem de extremidade foram utilizados nas lajes simplesmente apoiadas. Os resultados indicaram que todos os protótipos não alcançaram o momento fletor resistente referente a interação total, apresentando como modo de 
falha o cisalhamento longitudinal. Os protótipos com conectores de cisalhamento do tipo pino com cabeça apresentaram um aumento significativo de resistência ao cisalhamento longitudinal quando comparados aos protótipos sem ancoragem de extremidade. Além disso, foi verificado que a contribuição da ancoragem de extremidade na resistência ao cisalhamento longitudinal é governanda pelo deslizamento relativo de extemidade ao invés da resistência dos conectores de cisalhamento, ou seja, a resistência dos conectores não é totalmente mobilizada, pois antes disso ocorre a falha por cisalhamento longitudinal. As lajes contínuas também apresentaram maior resistência e flechas menores em relação aos protótipos simplesmente apoiados.

Mirza e Uy (2012) investigaram o comportamento das lajes mistas por meio de ensaios de curta e longa duração. No programa experimental foram utilizados quatro protótipos para os ensaios de curta duração e oito para os de longa duração. Os resultados dos ensaios de curta duração indicaram que a presença da ancoragem de extemidade aumentou a capacidade resistente, a rigidez e a ductibilidade do sistema. Nos ensaios de longa duração foi obsevado que os protótipos apresentaram flechas maiores devido aos efeitos da fluência e da retração no concreto.

Rana, Mirza e Uy (2015) realizaram uma série de ensaios com o objetivo de investigar os efeitos da ancoragem de extremidade por meio de conectores de cisalhamento na capacidade resistente e nos modos de colapso das lajes mistas. Um modelo tridimensional utilizando elementos finitos foi desenvolvido para simular o comportamento das lajes mistas com conectores de cisalhamento nos apoios. Os resultados experimentais mostraram que os conectores de cisalhamento tiveram efeito positivo na capacidade resistente das lajes maciças e mistas ensaiadas, independente da duração e das condições do carregamento aplicado, no entanto, para um aumento de $300 \mathrm{MPa}$ para $700 \mathrm{MPa}$ na resistência dos conectores não gerou nenhum efeito na capacidade resistente da laje, uma vez que a interação total entre a fôrma de aço e o concreto foi atingida

Degtyarev (2013) desenvolveu um modelo analítico para a determinação da resistência ao cisalhamento longitudinal de lajes mistas com ancoragem de extremidade. Este modelo leva em consideração a resistência e a flexibilidade dos conectores de cisalhamento, a resistência ao cisalhamento longitudinal, a geometria da laje e as propriedades da fôrma de aço e do concreto, sendo assim abrangente no que diz respeito à configuração dos sistemas de lajes mistas. Os valores de resistência obtidos pela aplicação do modelo proposto foram bastante próximos dos valores experimentais e, em média, $17 \%$ maior, sendo assim a favor da segurança da estrutura para aplicacões de projeto. Além disso, o método proposto pelo autor apresentou resultados mais 
próximos dos experimentais quando comparados com outros métodos disponíveis (interação parcial, SDI Handbook e Jolly e Lawson)

No mesmo ano, Degtyarev (2013) realizou um estudo paramétrico sobre a resistência das lajes mistas com ancoragem de extremidade e a mobilização da resistência dos conectores de cisalhamento levando em consideração os efeitos do número de conectores, a resistência ao cisalhamento longitudinal, características geométricas e mecânicas da fôrma de aço e do concreto. Além disso, o autor propôs uma formulação para a determinação do número mínimo de conectores de cisalhamento soldados necessários para alcancar o momento fletor resistente para interação total.

Chen at al. (2015) desenvolveram um estudo experimental e numérico com a finalidade de avaliar a resposta termoestrutural dos conectores de cisalhamento utilizados na ligação entre a laje mista e as vigas de aço, com ênfase nos perfis trapezoidais. Foram executados seis testes do tipo push-out em diferentes níveis de temperatura. Um modelo tridimensional utilizando elementos finitos foi desenvolvido e validado por meio de dados experimentais coletados no presente estudo. Os resulatdos obtidos em conjunto com os dados experimentais presentes na literatura foram utilizados para avaliar a acurácia das diretrizes normativas européias para determinar a resistência dos conectores de cisalhamento à elevadas temperaturas no caso da configuração do sistema estrutural estudado. Os resultados mostraram que a aplicação do método proposto pelo EUROCODE 4 é conservadora e, por essa razão, este estudo propôs novo modelo de cálculo que apresentou resultados mais próximos dos experimentais.

\subsection{COMPORTAMENTO GERAL DAS LAJES MISTAS SOB FLEXÃO}

Quando conduzido o ensaio de flexão a quatro pontos, recomendado pelo EUROCODE 4 (2004), até o colapso, as lajes mistas podem apresentar diferentes estados- limites últimos, tais quais: momento fletor, cisalhamento vertical, cisalhamento longitudinal e punção. Neste trabalho serão discutidos os aspectos relativos ao cisalhamento longitudinal. A Figura 2.4 ilustra o esquema geral desse tipo de ensaio. 
Figura 2. 4. Esquema geral do ensaio de lajes mistas.

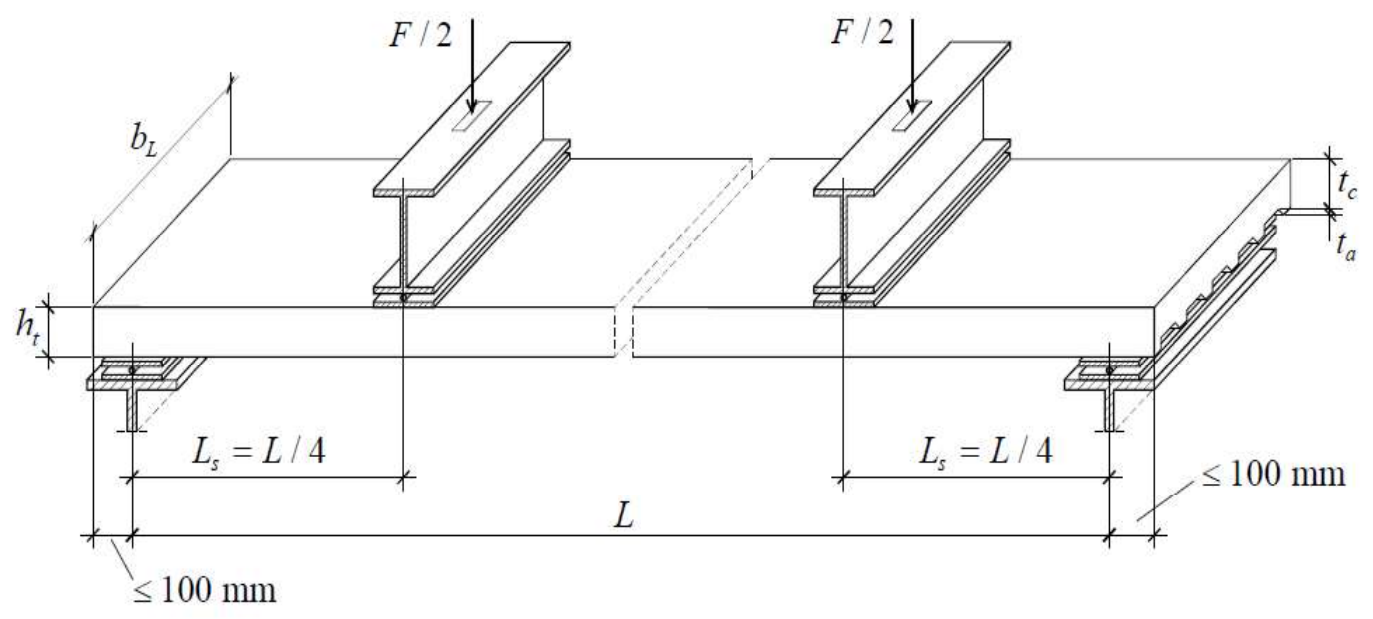

Fonte: Grossi (2016) adaptado do EUROCODE 4 (2004)

O comportamento geral das lajes mistas durante o ensaio de flexão foi detalhado no trabalho de Schuster e Seleim (1982). Segundo os autores, nos estágios iniciais de carregamento, antes da fissuração, a carga é suportada pelo aço e pelo concreto proporcionalmente às suas rigidezes, encontrando-se os materiais em interação completa. Schuster e Ling (1980) afirmam que os mecanismos de transferência de cisalhamento entre os dois materiais ainda não estão atuando durante este estágio de carregamento, apenas a aderência natural é responsável pela resistência ao deslizamento relativo entre fôrma de aço e o concreto.

Aumentado o carregamento aplicado, a carga adicional suportada pelo concreto se torna suficientemente grande para dar início ao surgimento de fissuras. Quase que simultaneamente ao surgimento das fissuras no ponto de aplicação dos carregamentos, o concreto do vão de cisalhamento começa a deslizar sob a forma de aço. Nessa fase, a interação ao cisalhamento longitudinal passa a ser parcial e a ligação mecânica e o atrito nos apoios são os responsáveis pela resistência ao deslizamento relativo.

Prosseguindo o ensaio, o sistema alcançará um estágio em que não é possível suportar acréscimos de carregamento e a carga útima é então atingida. No final do ensaio observa-se uma intensa fissuração do concreto entre os pontos de aplicação de caga, conforme ilustrado na Figura 2.5 . 
Figura 2. 5. Ilustração da fissuração no concreto ao final do ensaio de flexão de lajes mistas.

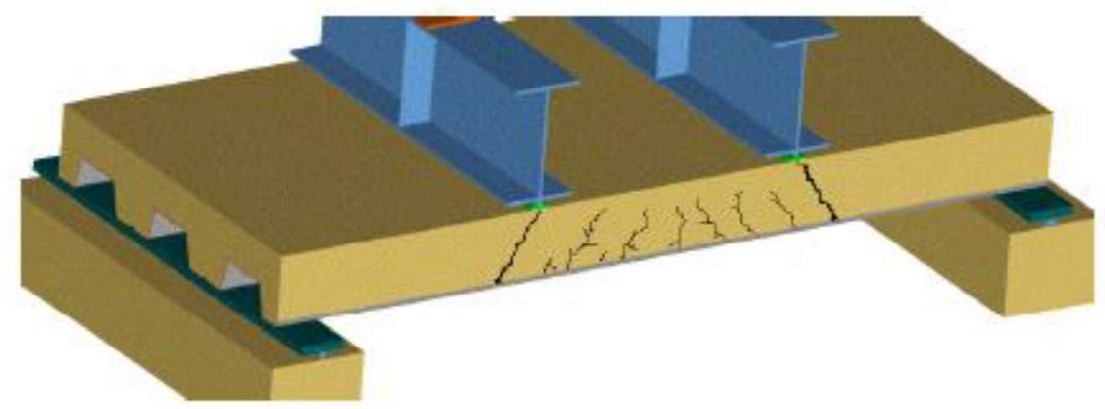

Fonte: Souza Neto (2001)

A classificação do Sistema de laje mista é de grande importância, uma vez que existem métodos de dimensionamento que são aplicados de acordo com comportamento dúctil ou frágil apresentado. A ABNT NBR 8800 (2008) não apresenta um método quantitativo para classificar as lajes mistas, recomendando apenas o EUROCODE 4 (2004) como referência. De acordo com esta norma, o comportamento é considerado dúctil se a força última $\left(\mathrm{F}_{\text {máx }}\right)$ excede à força que levou a um deslizamento relativo de extremidade de $0,1 \mathrm{~mm}\left(\mathrm{~F}_{\text {des }}\right)$ em mais de $10 \%$. O gráfico da Figura 2.6 apresenta a curva típica força $\mathrm{x}$ flecha de lajes mistas com comportamento dúctil.

Figura 3. 6. Curva força $\mathrm{x}$ flecha das lajes mistas dúcteis.

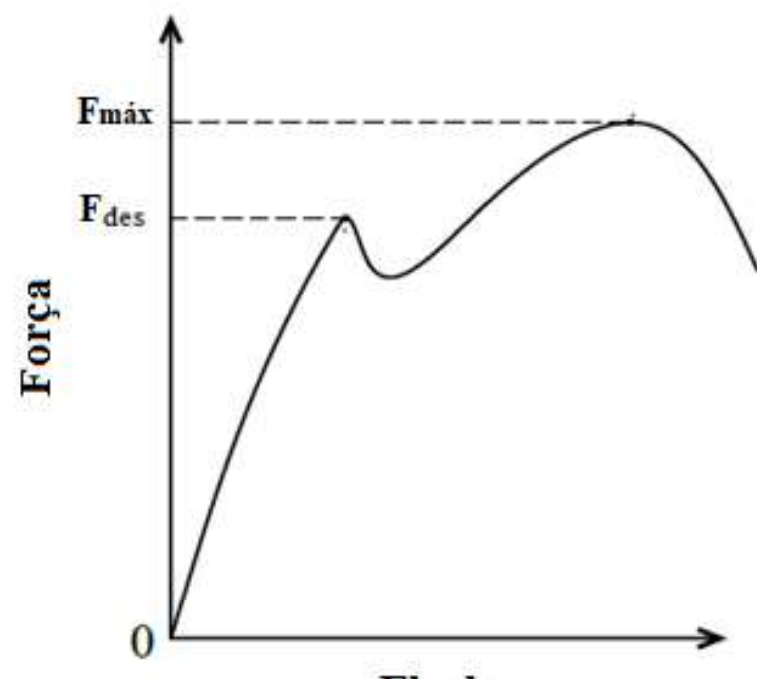

Flecha

Fonte: Adaptado de Grossi (2016) 
De acordo com a curva força x flecha da Figura 2.6, podemos observar que as lajes mistas dúcteis são capazes de suportar um considerável acréscimo de carregamento após atingir o estágio em que ocorre o deslizamento relativo de extremidade, processo este quase que simultâneo ao surgimento de fissuras.

Schuster e Ling (1980) apresentam em seu trabalho o comportamento da distribuição de tensões de cisalhamento para lajes dúcteis durante o ensaio de flexão. Segundo os autores, na fissuração, a distribuição de tensões de cisalhamento provenientes da ligação mecânica, no vão de cisalhamento, comporta-se de acordo com o gráfico da Figura 2.7 (a). Imediatamente após o início do processo de fissuração, a capacidade da ligação mecânica do sistema na região próxima as fissuras, é excedida. Nesta região, o atrito passa a ser mobilizado, permitindo que as lajes mistas sejam capazes de suportar acréscimos de carregamento, passando a distribuição de tensões de cisalhamento ao longo de $\mathrm{L}_{\mathrm{s}}$ a ser representada pelo gráfico da Figura 2.7 (b).

Figura 2. 7. Distribuição de tensões de cisalhamento para lajes dúcteis em ensaios de flexão.
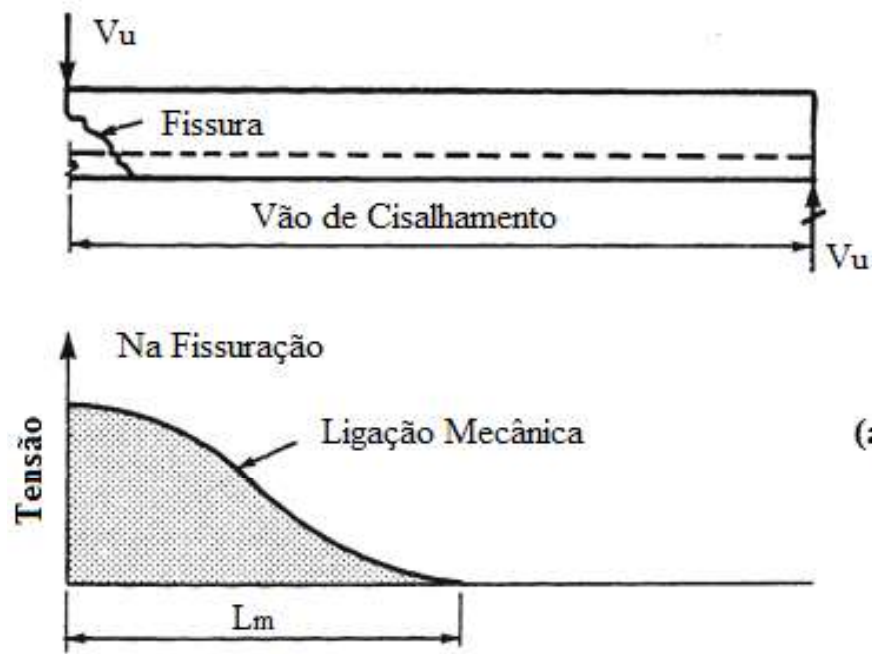

(a)

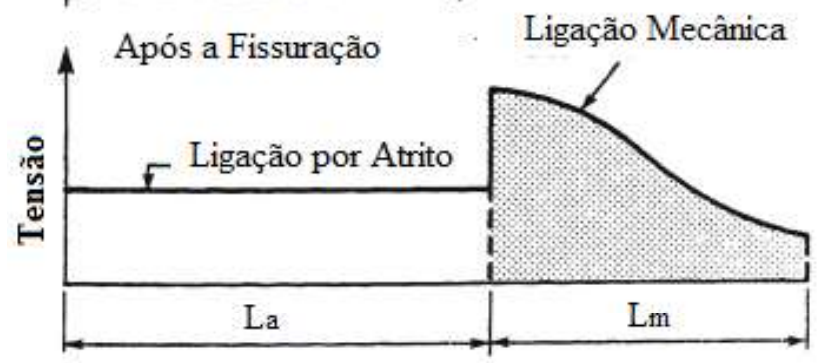

(b)

Fonte: Adaptado de Schuster e Ling (1980) 
A magnitude das tensões de cisalhamento provenientes da ligação mecânica e por atrito depende do tipo de mecanismo de transferência de cisalhamento adotado e da geometria do perfil da fôrma de aço.

As lajes mistas frágeis apresentam grande perda de rigidez quando a carga que gera o deslizamento relativo de extremidade é atingida, não suportando acréscimos de carregamento superiores a este nível. O gráfico da Figura 2.8 ilustra esse tipo de comportamento.

Figura 2. 8. Curva força $\mathrm{x}$ flecha das lajes mistas frágeis.

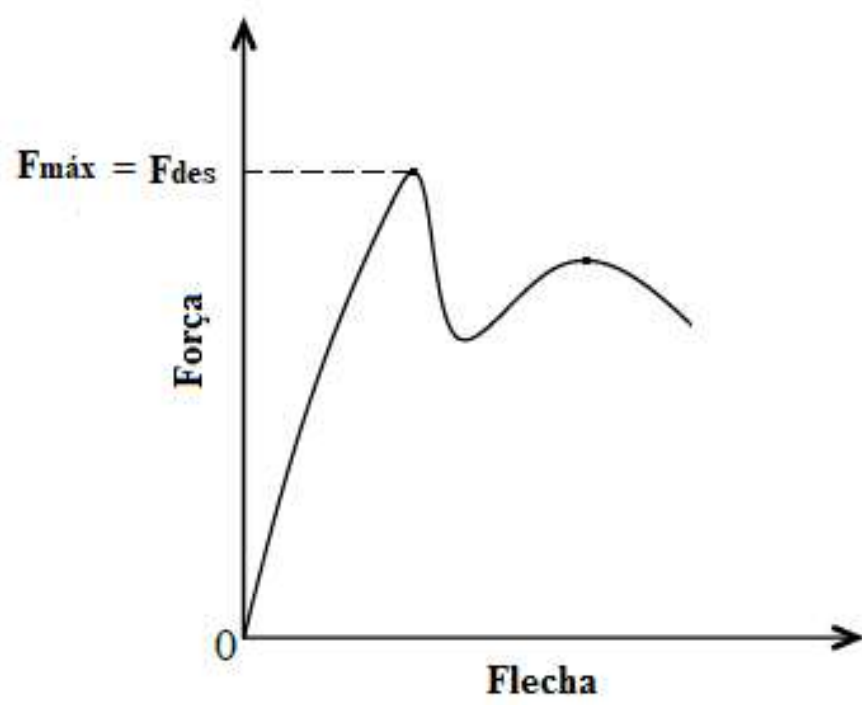

Fonte: adaptado de Grossi (2016)

Apresentados os estudos desenvolvidos no Brasil e no exterior sobre o comportamento estrutural e capacidade resistente das lajes mistas de aço e concreto, bem como o seu comportamento sob flexão e a sua classificação de acordo com a literatura, está consolidada a teoria que servirá como base para o desenvolvimento das equações de dimensionamento, discutido no capítulo seguinte. 


\section{VERIFICAÇÃO DE LAJES MISTAS}

Neste capítulo são descritos os procedimentos de cálculo da ABNT NBR 8800 (2008) e das normas estrangeiras por ela citadas para o dimensionamento de lajes mistas que consiste, de maneira geral, na verificação da fôrma de aço na fase inicial, ou seja, antes de o concreto atingir $75 \%$ da resistência à compressão especificada; na verificação dos estados-limites últimos e de serviço na fase final.

\subsection{VERIFICAÇÃO DA FÔRMA DE AÇO: FASE INICIAL}

As fôrmas metálicas consistem em chapas finas formadas a frio, em geral, galvanizadas nas faces para prevenir o processo de corrosão e devem ser verificadas isoladamente durante a fase em que o comportamento misto ainda não é verificado, uma vez que nesta fase, as chapas são responsáveis por suportar todos os esforços solicitantes. De acordo com a ABNT NBR 8800 (2008), devem ser verificados os estados-limites últimos e de serviço da fôrma de aço na fase inicial.

Para a verificação dos estados-limites últimos a ABNT NBR 8800 (2008) estabelece que a análise elástica seja utilizada e que a ABNT NBR 14762 (2010), que trata do dimensionamento de estruturas de aço constituídas por perfis formados a frio, seja utilizada como base. Para a verificação do estado-limite de serviço, o deslocamento máximo é limitado a $\mathrm{L}_{\mathrm{F}} / 180$ ou $20 \mathrm{~mm}$, considerando o peso próprio da fôrma e do concreto fresco, sendo $L_{F} O$ vão teórico da fôrma na direção das nervuras.

A norma brasileira estabelece que devem ser consideradas as seguintes ações para a determinação da resistência da fôrma de aço: pesos próprios do concreto fresco, da fôrma de aço, da armadura e da sobrecarga de construção. Além disso, para o caso em que o deslocamento no centro do vão da fôrma ultrapassar o valor de $L_{F} / 250$, sendo $L_{F} \mathrm{o}$ vão da laje na direção das nervuras, o efeito de empoçamento deve ser considerado por meio do acréscimo na espessura nominal do concreto de $70 \%$ do valor do deslocamento. 
Segundo a ABNT NBR 8800 (2008), a resistência de cálculo das lajes mistas deve ser suficiente para suportar as seguintes solicitações: momento fletor, cisalhamento longitudinal, cisalhamento vertical e punção. Queiroz et al. (2001) descrevem a ocorrência desses estados-limites últimos baseados nos modos de colapso possíveis, cujas seções críticas são apresentadas na Figura 3.1 .

Figura 3. 1. Seções críticas dos possíveis modos de colapso das lajes mistas.

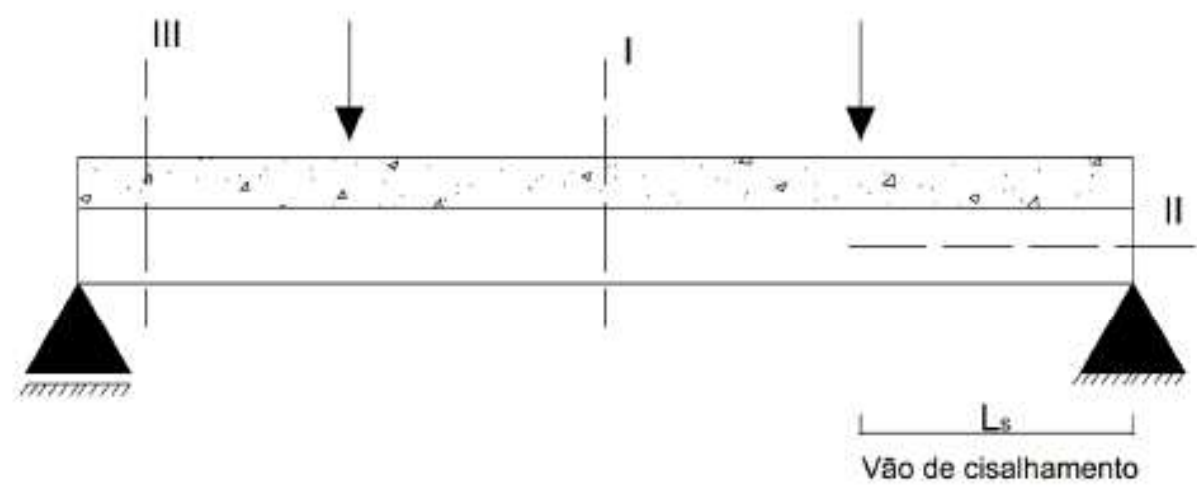

Fonte: Sieg (2015)

- Seção Crítica I: resistência à flexão. Pressupõe interação completa entre a fôrma e o concreto e pode ser crítico se o vão de cisalhamento $\left(\mathrm{L}_{\mathrm{S}}\right)$ for suficientemente grande.

- Seção Crítica II: Cisalhamento longitudinal. A carga máxima na laje é determinada pela resistência ao cisalhamento longitudinal, não sendo possível atingir a resistência última ao momento fletor. Caracteriza-se como ação mista de interação parcial.

- Seção Crítica III: Cisalhamento vertical. Este estado-limite pode ser crítico somente em casos especiais, por exemplo, em lajes espessas de vão curto sujeitas a cargas elevadas.

- Punção: este estado-limite pode ser crítico se o perímetro da área carregada e a espessura da laje forem pequenos e se a carga for elevada. 
Neste trabalho, o estado-limite último de interesse é o cisalhamento longitudinal, o mais usual nas lajes mistas, que será detalhado nos tópicos seguintes. Para os demais estados-limites últimos, apenas o momento fletor será apresentado devido a sua importância para o entendimento de um dos métodos de cálculo para a determinação da resistência ao cisalhamento longitudinal (método da interação parcial).

\subsubsection{Momento fletor}

O colapso por flexão pode ser crítico no caso em que a interação ao cisalhamento longitudinal entre a fôrma de aço e o concreto é completa, o que pode ser constatado pela ausência do deslizamento relativo de extremidade. Segundo as prescrições da ABNT NBR 8800 (2008), na determinação do momento fletor positivo resistente de cálculo, a fôrma deve resistir aos esforços de tração em conjunto com a armadura adicional, caso exista, posicionada na face inferior da laje. $\mathrm{Na}$ determinação do momento fletor negativo resistente de cálculo sobre os apoios em lajes contínuas, a contribuição da fôrma de aço aos esforços de compressão somente deve ser considerada caso haja continuidade da fôrma. Além disso, deve-se assegurar a inexistência da flambagem local da fôrma de aço preenchida com concreto. Desta forma, a largura plana de todos os elementos da fôrma, ilustrada na Figura 3.2, independente da existência de mossas, deve atender à seguinte exigência:

$$
\begin{gathered}
b_{F} \leq \frac{26,49 \sqrt{\frac{E}{f_{y, F}}}}{(13 \alpha-1)} t_{F} \quad \text { quando } \alpha \geq 0,5 \\
b_{F} \leq \frac{2,40 \sqrt{\frac{E}{f_{y, F}}} t_{F} \quad \text { quando } \alpha<0,5}{\alpha}
\end{gathered}
$$

Onde

$\alpha$ é a relação entre a largura da parte comprimida e a largura plana do elemento; $t_{\mathrm{F}}$ é a espessura da fôrma de aço; 
E é o módulo de elasticidade do aço da fôrma;

$\mathrm{f}_{\mathrm{yF}}$ é a resistência ao escoamento da fôrma de aço.

Figura 3. 2. Largura plana dos elementos da fôrma.

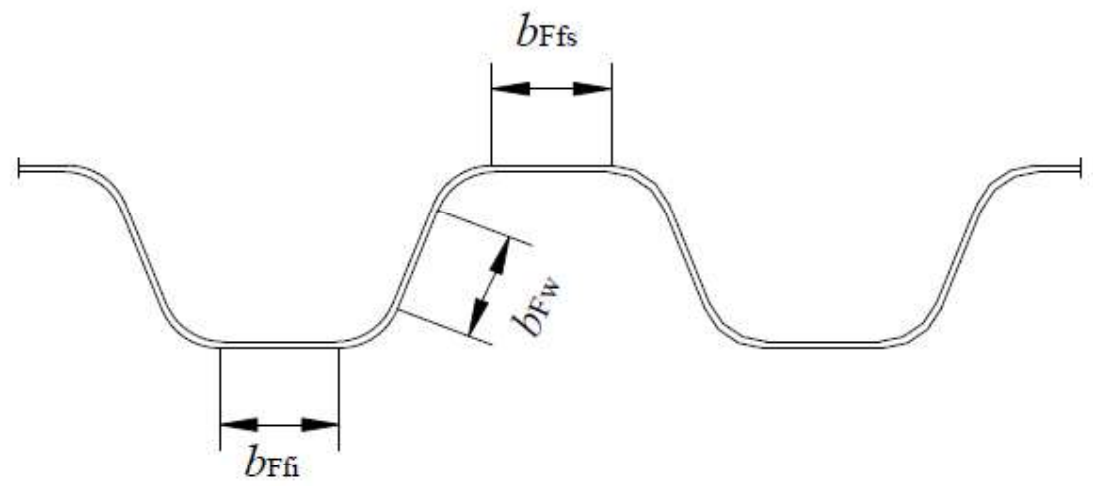

Fonte: ABNT NBR 8800 (2008)

A norma brasileira apresenta duas situações possíveis na determinação do momento resistente de cálculo:

1) Linha neutra plástica acima da face superior da fôrma de aço

A distribuição de tensões ao longo da seção tranversal da laje mista sob momento fletor positivo é representada na Figura 3.3.

Figura 3. 3. Diagrama de tensões para momento positivo com linha neutra plástica acima da fôrma de aço.

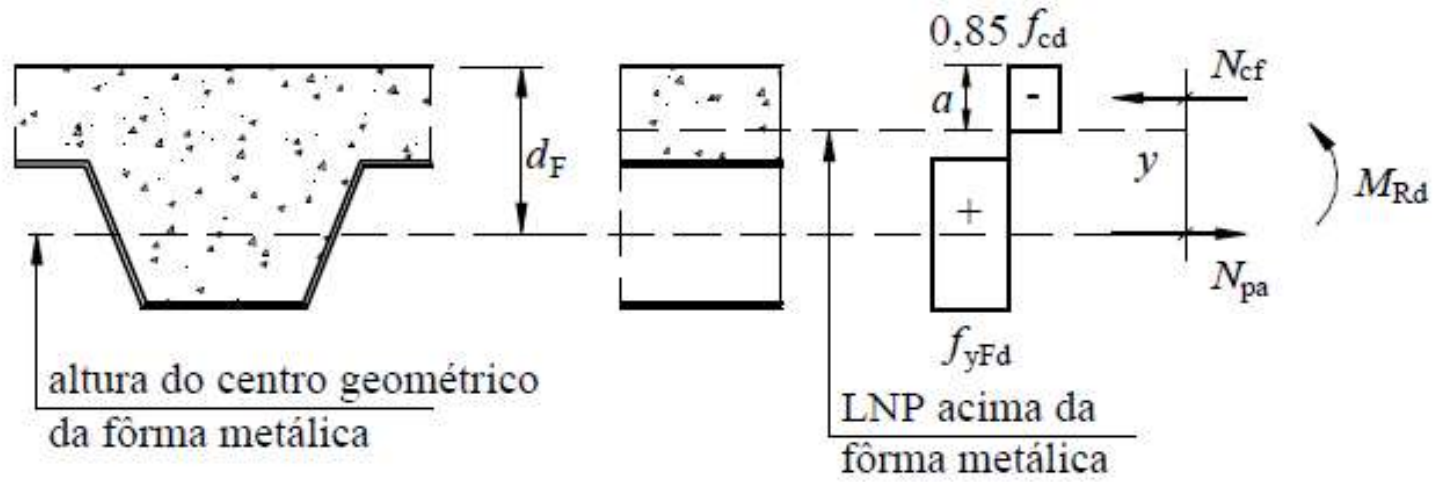

Fonte: ABNT NBR 8800 (2008) 
Quando não há armadura adicional, o momento fletor positivo resistente de cálculo é dado pela equação 3.3 .

$$
M_{R d}=N_{p a}\left(d_{F}-0,5 a\right)
$$

Onde

$d_{\mathrm{F}}$ é a distância da face superior da laje de concreto ao centro geométrico da seção efetiva da fôrma; $a$ é a altura do bloco de compressão do concreto dada pela equação 3.4.

$$
a=\frac{N_{p a}}{0,85 f_{c d} b}
$$

Onde

$b e ́$ a largura unitária da laje, tomada igual a $1000 \mathrm{~mm}$;

$f_{c d}$ é o valor de cálculo da resistência a compressão do concreto $\left(f_{c k} / 1,4\right)$;

$N_{p a}$ é a força normal no aço (o índice $p$, em inglês, refere-se a plastic), dada pela equação 3.5 .

$$
N_{p a}=A_{F, e f} f_{y, F d}
$$

Sendo $A_{F, e f}$ é a área da seção efetiva da fôrma (correspondente a $1000 \mathrm{~mm}$ ), determinada desprezando-se a largura das mossas na seção transversal, a menos que se demonstre por meio de ensaios que uma área maior possa ser utilizada e $f_{y F d}$ é a resistência ao escoamento de cálculo do aço da fôrma $\left(f_{y F k} / 1,10\right)$.

\section{2) Linha neutra plástica abaixo da face superior da fôrma de aço}

Para este caso, adota-se a simplificação de cálculo de desconsiderar a resistência do concreto contido na nervura A Figura 3.4 apresenta a distribuição de tensões na seção transversal. 
Figura 3. 4. Diagrama de tensões para momento positivo com linha neutra plástica na fôma de aço.

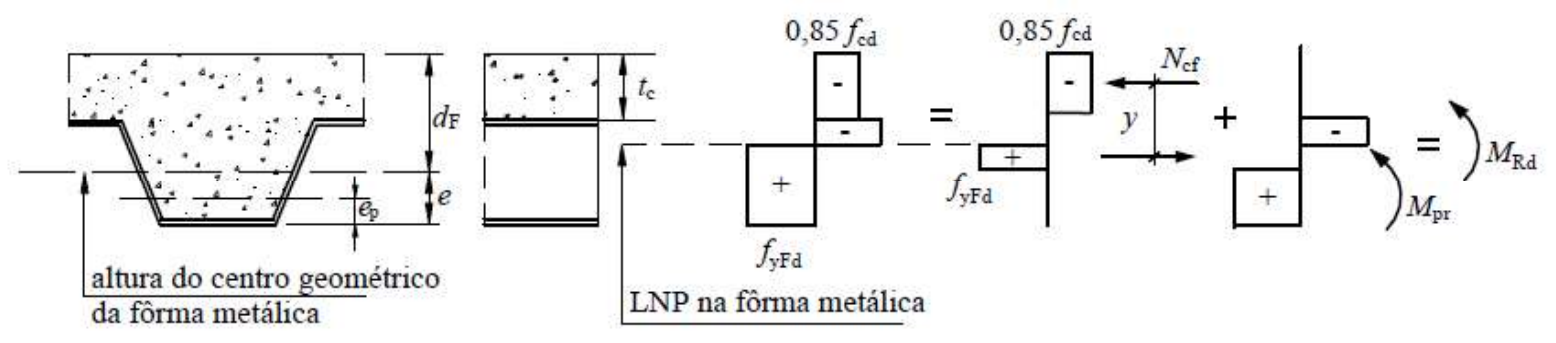

Fonte: ABNT NBR 8800 (2008)

Neste caso, quando não há armadura adicional, o momento fletor positivo resistente de cálculo e dado pela equação 3.6.

$$
M_{R d}=N_{c f} y+M_{p r}
$$

Onde

$N_{c f}$ é a força normal no concreto ( o índice $f$, em inglês, refere-se a full interaction que significa interação completa) dada pela equação 3.7; y calculado pela equação 3.8 e $M_{p r}$ é o momento de plastificação da fôrma de aço, reduzido pela presença da forca axial dado pela equação 3.9.

$$
N_{c f}=0,85 b t_{c} f_{c d}
$$

Onde

$t_{c}$ é a altura da laje de concreto acima do topo da forma de aço;

$$
y=h_{t}-0,5 t_{c}-e_{p}+\left(e_{p}-e\right) \frac{N_{c f}}{N_{p a}}
$$

Onde

$h_{t}$ é a altura total da laje;

$e_{p}$ é a distância da linha neutra plástica da seção efetiva da forma a sua face inferior;

$e$ é a distância do centro geométrico da área efetiva da fôrma de aço a sua face inferior. 


$$
M_{p r}=1,25 M_{p a}\left(1-\frac{N_{c f}}{N_{p a}}\right) \leq M_{p a}
$$

Onde

$M_{p a}$ é o momento de plastificação da fôrma, considerando sua seção efetiva, dividido pelo coeficiente de ponderação da resistência $\gamma_{a l}$.

A relação entre $M_{p r} / M_{p a}$ e $N_{c} / N_{p a}$ depende da geometria da fôrma, mas varia tipicamente conforme a linha cheia ABC na Figura 3.5. O EUROCODE 4 (2004) aproxima esta linha pela equação 4.9, representada graficamente pela linha tracejada ADC na Figura 3.5.

Figura 3. 5. Diagrama de interação entre a força axial e o momento na fôrma de aço.

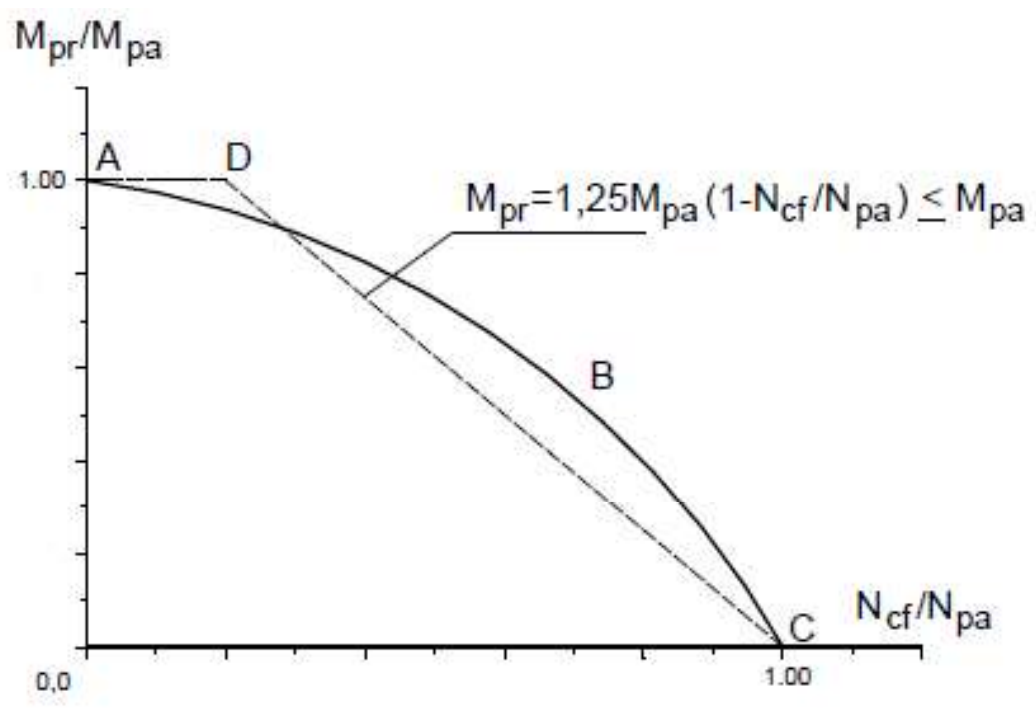

Fonte: Souza Neto (2001)

As expressões acima são validas para os casos em que não há armadura adicional para resistir ao momento fletor positivo, caso contrário, a ABNT NBR 8800 (2008) estabelece que as expressões sejam adequadamente ajustadas. Grossi (2016) apresenta as expressões para o cálculo do momento resistente em lajes mistas com armadura adicional, admitindo interação completa. 


\subsubsection{Cisalhamento longitudinal}

O colapso por cisalhamento longitudinal é caracterizado pela ocorrência de um elevado deslizamento relativo entre a fôrma de aço e o concreto na extremidade da laje, fazendo com que haja a perda da ação composta entre os dois materias, indicando que o momento fletor resistente para interação completa, associado ao colapso por flexão, não foi alcançado.

A ANBT NBR 8800 (2008) apresenta dois métodos para a determinação da resistência ao cisalhamento longitudinal das lajes mistas: o método $m-k$ e o método da interação parcial. Para a utilização do método $m$ - $k$, a norma brasileira cita o EUROCODE 4 (2004), o CSSBIS2-2008 (2008) e ANSI/ASCE 3-91 (1992), para o método da interação parcial, é mencionado apenas o EUROCODE 4 (2004). Os dois métodos estão detalhados nos tópicos a seguir.

\subsubsection{Método $\mathrm{m}-\mathrm{k}$}

O método $m-k$ é reconhecido internacionalmente como método padrão para o cálculo da força cortante última associada ao estado-limite de cisalhamento longitudinal. A adoção deste método leva em consideração a contribuição dos mecanismos de resistência ao cisalhamento longitudinal provenientes das ligações mecânica e por atrito. Baseado no ensaio de flexão de lajes mistas, a aplicação deste método, originalmente proposto por Schuster (1970), era restrita a lajes mistas classificadas como frágeis, no entanto as equações foram aprimoradas e em 1980 Schuster e Ling propuseram um equacionamento que define o método atualmente utilizado que pode ser aplicado tanto em lajes com comportamento frágil quanto dúctil.

O cálculo da resistência ao cisalhamento longitudinal é feito por meio da equação semiempírica 3.10 que relaciona a resistência nominal ao esforço cortante com os parâmetros oriundos dos ensaios de flexão de lajes mistas recomendado pelo EUROCODE 4 (2004). Trata-se de ensaios na condição estática simplesmente apoiada, com duas forças concentradas situadas a L/4 dos apoios. O esquema geral do ensaio está ilustrado na Figura 3.4.

$$
\frac{V_{t}}{b_{L} d_{F}}=\frac{m}{L_{s}}+k
$$


Onde

$\mathrm{V}_{\mathrm{t}}$ é a forca cortante última associada ao estado-limite último de cisalhamento longitudinal obtida experimentalmente;

bL é a largura da seção transversal da laje;

$d_{F}$ é a distância da face superior da laje de concreto ao centro geométrico da seção efetiva da fôrma; Ls é o vão de cisalhamento;

m e k são constantes empíricas determinadas a partir de dados experimentais.

A equação 3.10 é valida apenas para uma determinada espessura e tipo de fôrma de aço. Sua dedução pode ser encontrada em Schuster e ling (1980).

O critério geral para a determinação do vão de cisalhamento $\left(\mathrm{L}_{\mathrm{s}}\right)$ é apresentado na ABNT NBR 8800 (2008) e no EUROCODE 4 (2004). Segundo estas normas, o vão de cisalhamento deve ser tomado como:

- L/4 para cargas uniformemente distribuídas ao longo do vão teórico da laje L, na direção das nervuras;

- A distância entre uma carga aplicada e o apoio mais próximo para duas cargas concentradas simétricas;

- A relação entre o máximo momento e a maior reação de apoio, para outras condições de carregamento.

Os valores de $b_{L}, d_{F}$ e $L_{S}$ são previamente determinados e o valor experimental representativo da força cortante $\left(\mathrm{V}_{\mathrm{t}}\right)$ é obtido diretamente do ensaio. $\mathrm{O}$ valor de $\mathrm{F}_{\text {total }}$ é dado pela equação 3.11 e inclui o peso próprio do protótipo $\left(\mathrm{PP}_{\text {prot }}\right)$ e dos dispositivos de distribuição de força $\left(\mathrm{P}_{\text {disp }}\right)$, além da máxima força aplicada $\left(\mathrm{F}_{\max }\right)$. Assim:

$$
F_{\text {total }}=F_{\text {max }}+P P_{\text {prot }}+P_{\text {disp }}
$$

De posse dos resultados, é estabelecida a reta dada pela equação 3.12 de melhor ajuste aos dados experimentais.

$$
y=m x+k
$$

Onde: 


$$
y=\frac{V_{t}}{b_{L} d_{F}} \quad \text { e } \quad x=\frac{1}{L_{s}}
$$

De acordo com a equação 3.12, pode-se perceber que as constantes m e k representam respectivamente o coeficiente angular e linear da reta obtida. De posse dos valores das constantes empíricas, determina-se o valor da resistência nominal ao esforço cortante $\left(\mathrm{V}_{\mathrm{u}}\right)$, calculada por meio da equação 3.13 .

$$
V_{u}=b_{L} d_{F}\left(\frac{m}{L_{S}}+k\right)
$$

A seguir são apresentadas as equações para a determinação da resistência de cálculo ao cisalhamento longitudinal através do método $m-k$ de acordo com as normas citadas pela ABNT NBR 8800 (2008).

\section{1) EUROCODE 4 (2004)}

Esta norma utiliza como notação para a força estimada pela reta normativa $V_{l, R k}$, substituindo a parcela $\frac{m}{L_{s}}$ por $\frac{m A_{p}}{b_{L} L_{s}}$.

De acordo com as prescrições desta norma, a força de cisalhamento máxima $\left(\mathrm{V}_{\mathrm{Ed}}\right)$ para uma laje de largura $b_{L}$ não deve ultrapassar a força resistente de cálculo $\left(\mathrm{V}_{1, \mathrm{Rd}}\right)$, determinada pala equação 3.14 .

$$
V_{l, R d}=\frac{b_{L} d_{p}}{\gamma_{v s}}\left(\frac{m A_{p}}{b_{L} L_{s}}+k\right)
$$

Onde

$\mathrm{d}_{\mathrm{P}}=\mathrm{d}_{\mathrm{F}}$ é a distância da face superior da laje de concreto ao centro geométrico da seção efetiva da fôrma em mm;

$\mathrm{A}_{\mathrm{p}}$ é a área nominal da seção transversal da fôrma de aço em $\mathrm{mm}^{2}$

m e k constantes empíricas em $\mathrm{N} / \mathrm{mm}^{2}$;

$\gamma_{V S}$ é o coeficiente de seguranca para o estado-limite último. 
O valor de $\gamma_{V S}$ recomendado por esta norma e de 1,25.

Conforme já mencionado, o método $m$ - $k$ pode ser utilizado para o cálculo da resistência ao cisalhamento longitudinal de lajes mistas que apresentam comportamento dúctil ou frágil. No entanto, para utilização deste método em lajes frágeis, O EUROCODE 4 (2004) exige que o valor da força cortante obtido experimentalmente $\left(\mathrm{V}_{\mathrm{t}}\right)$ seja multiplicadado por 0,8 . Além disso, a máxima força aplicada $\left(\mathrm{F}_{\max }\right)$ é limitada à força correspondente a flecha $\mathrm{L} / 50$ para que o carregamento máximo não ocorra sob grandes deslocamentos verticais.

Para a determinação das constantes $\mathrm{m}$ e $\mathrm{k}$, esta norma estabelece que para cada variável a ser investigada, dois grupos de três testes, indicados na Figura 3.6 pelas regiões A e B, ou três grupos de dois testes devem ser realizados. Para os protótipos da região A e B, o vão de cisalhamento deve ser, respectivamente, o maior e o menor possível de modo que não comprometa o colapso por cisalhamento longitudinal.

Figura 3. 6. Determinação experimental das constantes m e k.

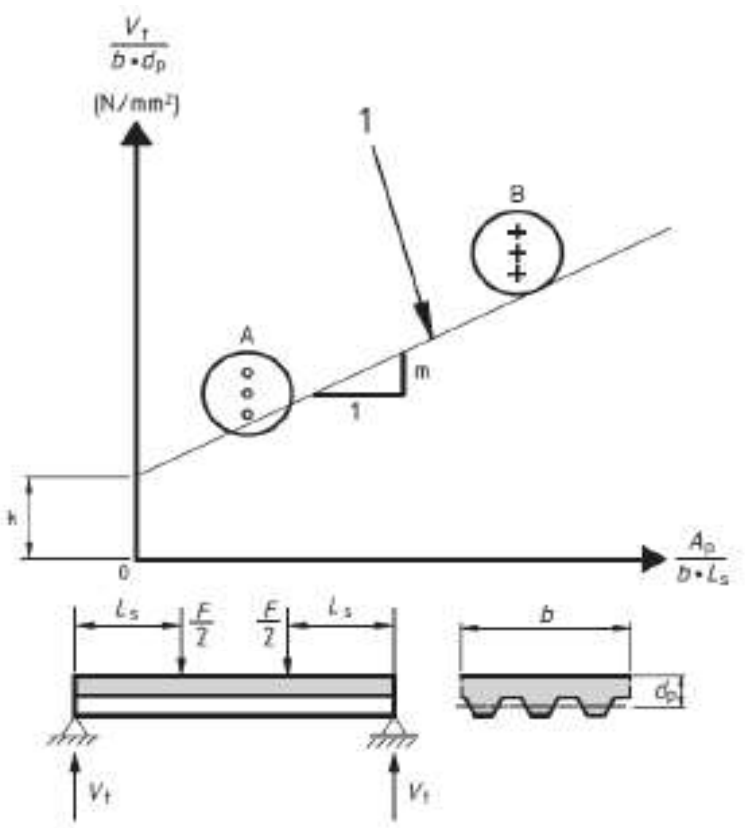

Fonte: EUROCODE 4 (2004)

Para o cálculo do valor característico, o Eurocode 4 (2004) considera o valor característico inferior (quantil de 5\%) dos valores obtidos experimentalmente, conforme a equação 3.15. 


$$
\vartheta_{K}=\vartheta_{m}-1,65 S
$$

Onde $\vartheta_{m}$ é o valor médio e S é o desvio-padrão.

\section{2) $\underline{\text { CSSBI S2 - } 2008(2008)}$}

A equação 3.16 apresentada por esta norma para a determinação da resistência característica ao esforço cortante pouco difere da apresentada pelo EUROCODE 4 (2004), sendo feitas as seguintes modificações:

$$
V_{t}=b_{L} d_{F}\left(\frac{k_{5}}{L_{s}}+k_{6}\right)
$$

$\mathrm{V}_{\mathrm{t}}=\mathrm{V}_{\mathrm{l}, \mathrm{Rk}}$ é a força cortante última característica relacionada ao cisalhamento longitudinal obtida da reta normativa;

$\mathrm{k}_{5}=\mathrm{m} \mathrm{e} \mathrm{k}_{6}=\mathrm{k}$

A força resistente de cálculo $\left(V_{r}\right)$ é dada pelaequação 3.17.

$$
V_{r}=\phi V_{t}
$$

Sendo $\emptyset$ o coeficiente de ponderação com valor considerado de 0,70 .

De acordo com esta norma, se os desvios entre os dados experimentais e a reta obtida forem iguais ou superiores a $15 \%$, os valores de $m$ e $k$ devem ser reduzidos em $5 \%$.

\section{3) ANSI/ASCE 3-91(1992)}

O cálculo da força cortante última característica é feita por meio da equação 3.18 .

$$
\frac{V_{n}}{b d_{F}}=m_{p} \frac{\rho_{a} d_{F}}{L_{s}}+k_{p} \sqrt{f_{c k}}
$$

Onde

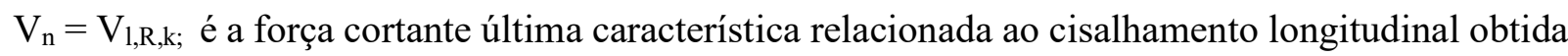
da reta normativa; 
$\mathrm{m}_{\mathrm{p}}$ e $\mathrm{k}_{\mathrm{p}}$ são constantes determinadas experimentalmente;

$f_{\text {ck }}$ é a resistência característica à compressão do concreto.

A taxa de aço $\left(\rho_{a}\right)$ é dada pela equação 3.19 .

$$
\rho_{a}=\frac{A_{p}}{b_{L} d_{F}}
$$

Quanto à determinação da resistência de cálculo, a ANSI/ASCE 3-91 (1992) estabelece que o valor do coeficiente de minoração $\emptyset$ seja de 0,75 .

No que diz respeito à dispersão dos dados experimentais, esta norma preconiza que caso sejam utilizadas oito ou mais amostras, deve ser feita uma redução de $10 \%$ da reta obtida, caso contrário, a redução deve ser de 15\%.

\subsubsection{Método da interação parcial}

Conforme já mencionado, para a determinação do esforço resistente ao cisalhamento longitudinal, a ABNT NBR 8800 (2008) permite a utilização do método $m-k$ e do método da interação parcial que determinam, respectivamente, a forca cortante última e o momento fletor resistente associados ao estado-limite último de cisalhamento longitudinal. Para a aplicação do método da interação parcial, a ABNT NBR 8800 (2008) menciona diretamente o EUROCODE 4 (2004), que restringe a utilização deste método apenas para lajes mistas que apresentam comportamento dúctil.

Segundo Johnson (1994), além de explorar melhor o comportamento dúctil das lajes mistas, o método da interação parcial permite a avaliação da contribuição da ancoragem de extremidade na resistência ao cisalhamento longitudinal, objeto de estudo deste trabalho.

Considerando a hipótese de interação parcial ao cisalhamento longitudinal, e, portanto, a ocorrência de deslizamento relativo entre a fôrma de aço e o concreto, admite-se uma distribuição de tensões de plastificação nos materiais com a presença de duas linhas neutras plásticas dependentes entre si, uma no concreto $\left(\mathrm{LN}_{\mathrm{c}}\right)$ e outra na fôrma de aço $\left(\mathrm{LN}_{\mathrm{a}}\right)$. Esta distribuição encontra-se representada na Figura 3.7. 
Figura 3. 7. Distribuição das tensões normais para o método da interação parcial.

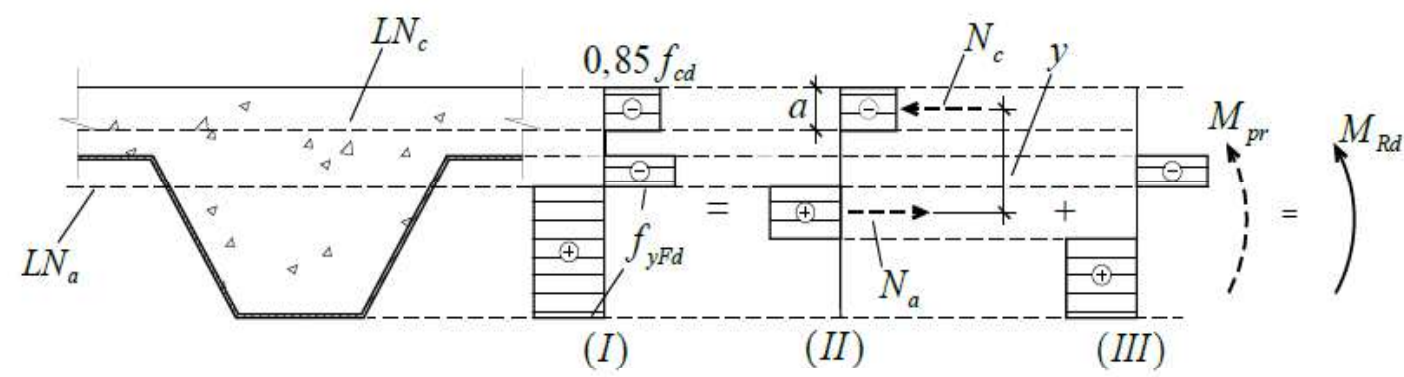

Fonte Grossi (2016)

Ao compararmos a distribuição das tensões normais para os casos de interação parcial (Figura 3.7) e interação completa com linha neutra plástica abaixo da face superior da fôrma (Figura 3.4), podemos concluir que a única diferença apresentada é a presença de concreto tracionado acima da face superior da fôrma que, na verdade, é desconsiderado para efeito de cálculo. Assim, o procedimento de cálculo para os dois casos citados é bastante semelhante, devendo-se apenas substituir a força de compressão no concreto $\left(\mathrm{N}_{\mathrm{cf}}\right)$ por $\mathrm{N}_{\mathrm{c}}$ que depende da resistência ao cisalhamento longitudinal.

Para o presente caso, as expressões apresentadas no item 3.2.1 são agora escritas da seguinte maneira:

$$
\begin{aligned}
& M_{R d}=N_{c} y+M_{p r} \\
& M_{p r}=1,25 M_{p a}\left(1-\frac{N_{c}}{N_{p a}}\right) \leq M_{p a} \\
& y=h_{t}-0,5 t_{c}-e_{p}+\left(e_{p}-e\right) \frac{N_{c}}{N_{p a}}
\end{aligned}
$$

De acordo com o EUROCODE 4 (2004), a expressão para o cálculo da força de compressão Nc é dada pela equação 3.23.

$$
N_{c}=\tau_{u, R d} b_{L} L_{x} \leq N_{c f}
$$

Onde 
$\tau_{u, R d}$ é a tensão resistente de cálculo ao cisalhamento longitudinal atendendo aos requisitos básicos do método da interação parcial;

$L_{x}$ é a distância da seção transversal considerada ao apoio mais próximo;

$N_{c f}$ é a força resultante de compressão no concreto para interação completa.

A expressão de $N c$ é determinada com base no equilíbrio das forças horizontais no concreto de uma determinada seção transversal, indicadas na Figura 3.8.

Figura 3. 8. Forças horizontais atuantes no concreto em uma determinada seção.

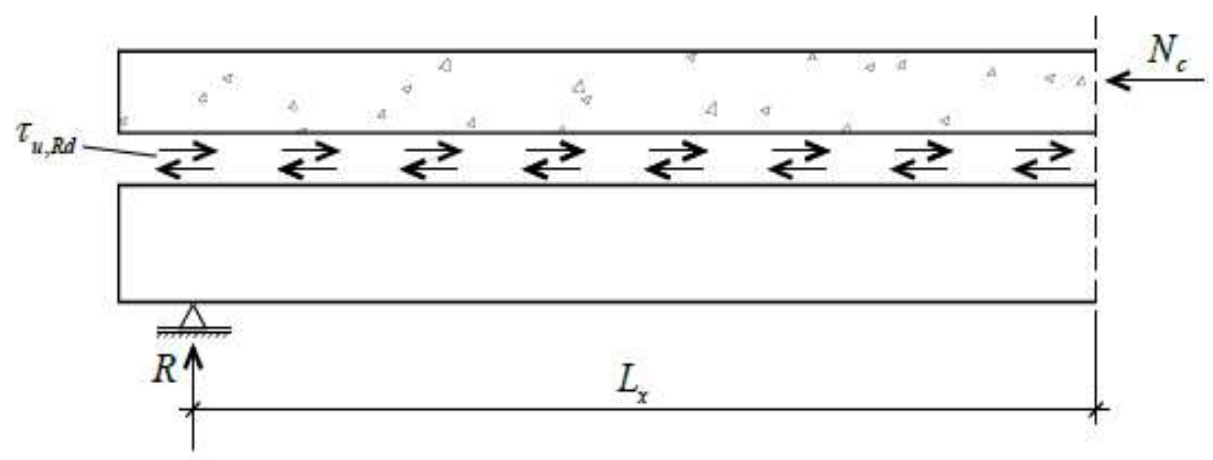

Fonte: Grossi (2016)

O atrito na região dos apoios causa um aumento na resistência ao cisalhamento longitudinal, considerado pelo EUROCODE 4 (2004) por meio da adição do termo $\mu R_{E d}$ na expressão de $N_{c}$ (equação 3.23), obtendo-se a equação 3.24

$$
N_{c}=\tau_{u, R d} b_{L} L_{x}+\mu R \leq N_{c f}
$$

Onde $R$ é a reação de apoio e $\mu$ o coeficiente de atrito estático de valor recomendado igual a 0,5.

Segundo Queiroz, Pimenta e Da Mata (2001), o EUROCODE 4 (2004) leva em consideração que parte da contribuição do atrito já foi considerada na determinação da tensão de cisalhamento $\left(\tau_{u, R d}\right)$ quando adota o valor de 0,5 para o coeficiente de atrito, uma vez que os valores obtidos experimentalmente são superiores.

Para a determinação da tensão última média de cisalhamento longitudinal $\left(\tau_{u}\right)$, este método admite que no estado-limite último do sistema de laje mista, as tensões de cisalhamento 
longitudinais são redistribuídas na interface aço-concreto, de modo que $\tau_{u}$ é obtida pela equação 3.25 .

$$
\tau_{u}=\frac{\eta N_{c f}}{b_{L}\left(L_{s}+L_{0}\right)}
$$

Onde

$L_{o}$ é o comprimento do balanço na extremidade do protótipo;

$L_{s}$ é o vão de cisalhamento;

$b_{L}$ é a largura da laje;

$\eta$ é o grau de interação parcial ao cisalhamento, dado pela equação 3.26

$$
\eta=\frac{N_{C}}{N_{c f}}
$$

Para a determinação do grau de interação, deve-se traçar o diagrama de interação parcial para cada protótipo, proposto pelo EUROCODE 4 (2004) (Figura 4.9). Neste diagrama o eixo y corresponde aos valores de $M / M_{p, R m}$ e o eixo $x$ aos valores de $\eta=N_{c} / N_{c f}$. $M$ é o momento fletor último devido ao carregamento aplicado, peso próprio da laje e dos equipamentos, que se refere à seção de aplicação da força do ensaio distante $L s$ do apoio mais próximo, e $M_{p, R m}$ é o momento resistente da laje com interação total ao cisalhamento longitudinal, calculados considerando a plastificação total da seção. De posse do valor do momento fletor último, na seção de aplicação do carregamento, que provoca a falha por cisalhamento longitudinal, correspondente ao protótipo em estudo $\left(M_{\text {test }}\right)$, obtém-se $\eta_{\text {test }}$ por meio do caminho $\mathrm{A} \rightarrow \mathrm{B} \rightarrow \mathrm{C}$ do diagrama. 
Figura 3. 9. Determinação gráfica do grau de interação parcial ao cisalhamento dos protótipos ensaiados.

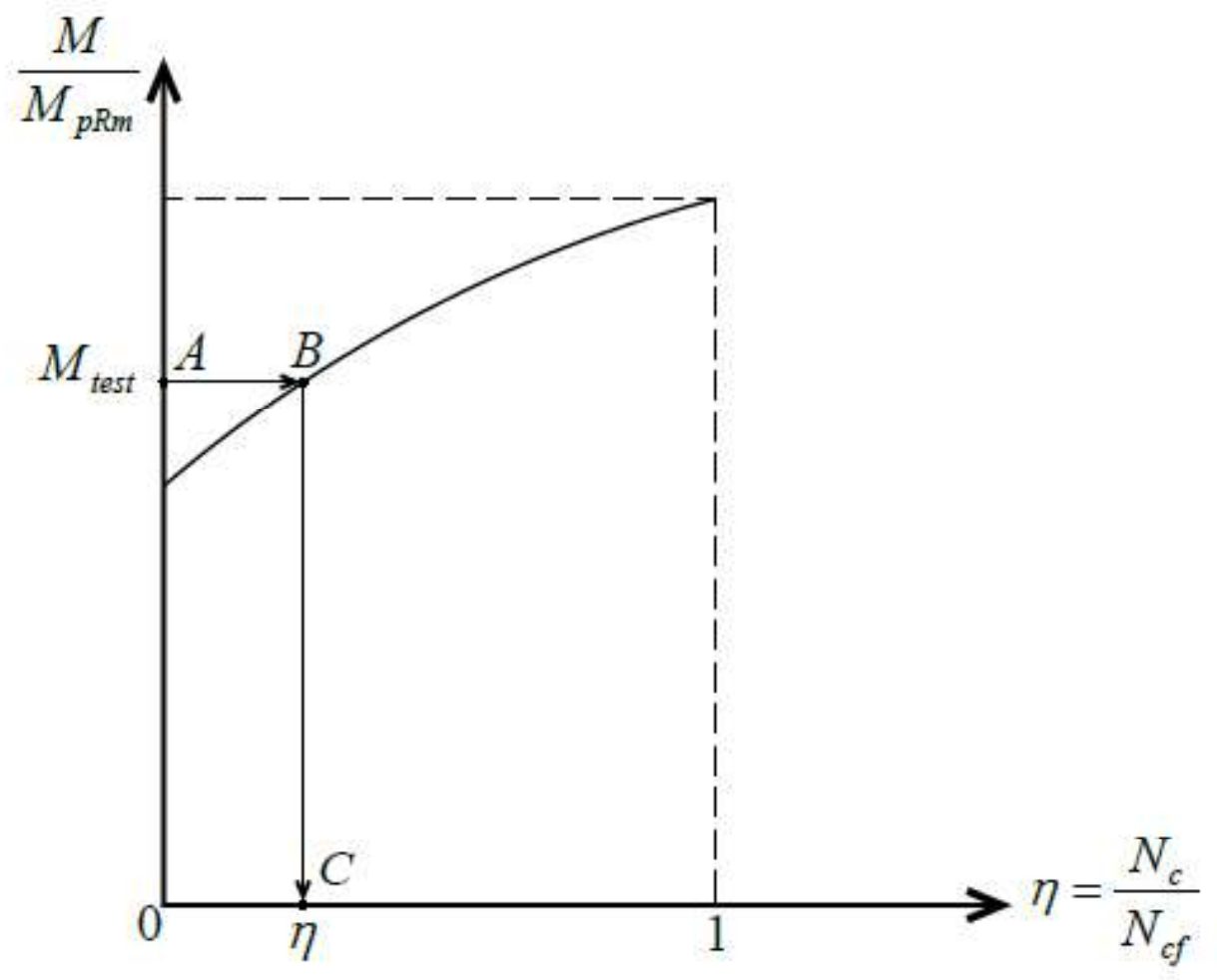

Fonte: Grossi (2016) adaptado do EUROCODE 4 (2004)

A tensão resistente de cálculo ao cisalhamento longitudinal $\left(\tau_{u, R d}\right)$ é a tensão resistente caracteristica $\tau_{u, R k}$ dividida pelo coeficiente de segurança $\left(\gamma_{V S}\right)$ com valor recomendado pelo EUROCODE 4 (2004) de 1,25. Esta norma ainda estabelece que $\tau_{u, R k}$ deve ser calculada como o valor referente a um percentil de $5 \%$ dos valores de $\tau_{u}$.

A equação 3.27 é utilizada para a determinação de $\tau_{u}$ quando a resistência ao cisalhamento proveniente da reação de apoio é considerada.

$$
\tau_{u}=\frac{\eta N_{c f}-\mu R}{b_{L}\left(L_{s}+L_{0}\right)}
$$

Onde

$R$ é a reação de apoio correspondente ao carregamento último e, como já citado, $\mu$ o coeficiente de atrito de valor recomendado igual a 0,5 . 
De acordo com o EUROCODE 4 (2004), a resistência ao cisalhamento longitudinal em lajes mistas com ancoragem de extremidade obtida por meio de conectores de cisalhamento ou pela deformação das nervuras na extremidade da chapa, deve ser determinada pelo método da interação parcial com $N_{c}$ aumentado pela resistência da ancoragem de extremidade.

O procedimento detalhado do método da interação parcial é descrito no item 5.3 onde são calculados os valores de resistência ao cisalhamento longitudinal das lajes mistas com conectores de cisalhamento nos apoios por meio deste método.

\subsection{VERIFICAÇÃO DA LAJE NA FASE FINAL: ESTADO-LIMITE DE SERVIÇO}

\subsubsection{Fissuração no concreto}

De acordo com A ABNT NBR 8800 (2008), para lajes calculadas como simplesmente apoiadas, é necessária a utilização de armadura com área não inferior a $0,1 \%$ da área de concreto acima da face superior da fôrma, com o objetivo de combater os efeitos de retração e temperatura. O posicionamento desta armadura deve ser preferencialmente a $20 \mathrm{~mm}$ abaixo do topo da laje.

A ABNT NBR 8800 (2008) cita a ABNT NBR 6118 (2003) para a verificação do estadolimite de fissuração do concreto de densidade normal em regiões de momento negativo de lajes continuas, e na ausência de normatização brasileira que possa ser aplicada, é sugerida a utilização do EUROCODE 2 part 1-1, para concretos de baixa densidade.

A norma brasileira ainda chama atenção para a possibilidade de fissuração nos locais onde possa haver tendência de continuidade dos elementos estruturais.

\subsubsection{Deslocamento vertical}

A ABNT NBR 8800 (2008) limita o deslocamento vertical nas lajes mistas a $L_{F} / 350$, sendo $L_{F}$ o vão teórico da laje na direção das nervuras. Apenas os efeitos das ações variáveis devem ser considerados neste cálculo. 
A norma brasileira não explicita as equações de homogeneização teórica da seção para o cálculo do momento de inércia da seção mista, necessário para o cálculo dos deslocamentos. Este equacionamento pode ser encontrado no CSSBI S2-2008 (2008), no ANSI/SDI C-2011 (2011) e no ANSI/ASCE 3-91 (1992).

Neste trabalho, as flechas teóricas, foram calculadas com base na média dos momentos de inércia considerando o concreto não fissurado e concreto fissurado. As expressões utilizadas podem ser encontradas no apêndice B. 


\section{PROGRAMA EXPERIMENTAL}

A análise do comportamento estrutural e da resistência ao cisalhamento longitudinal das lajes mistas foi realizada por meio de programa experimental em que oito protótipos simplesmente apoiados sem conectores de cisalhamento e dois protótipos com conectores nos apoios foram ensaiados . O procedimento experimental adotado neste trabalho consistiu na realização de ensaios de flexão de lajes mistas, recomendado pelo EUROCODE 4 (2004), detalhado no item 4.4.

Nos tópicos que seguem estão descritas as características dos materiais e dos protótipos ensaiados, bem como dos equipamentos utilizados e da instrumentação.

\subsection{CARACTERÍSTICAS DOS MATERIAIS}

\subsubsection{Fôrma de aço}

O perfil empregado na fabricação dos protótipos foi o Modular MD55, fornecido pela empresa Modular Sistema Construtivo, obtido a partir da perfilação a frio de chapa de aço zincada de alta resistência ASTM A653 grau 40 (ABNT NBR ZAR-280), fabricado seguindo as especificações da ABNT NBR 7008-3 (2012), com espessura nominal $t_{n}=0,8 \mathrm{~mm}$, revestimento de zinco de $275 \mathrm{~g} / \mathrm{m}^{2}$ e resistência ao escoamento fornecida pelo fabricante de $280 \mathrm{MPa}$. Para efeito de cálculo, desconta-se a espessura do revestimento de zinco, considerada igual a $0,04 \mathrm{~mm}$, resultando como espessura do aço $t_{\mathrm{F}}=0,76 \mathrm{~mm}$. A Figura 4.1 ilustra o perfil de aço utilizado. 
Figura 4. 1. Perfil da fôrma de aço modular MD55.

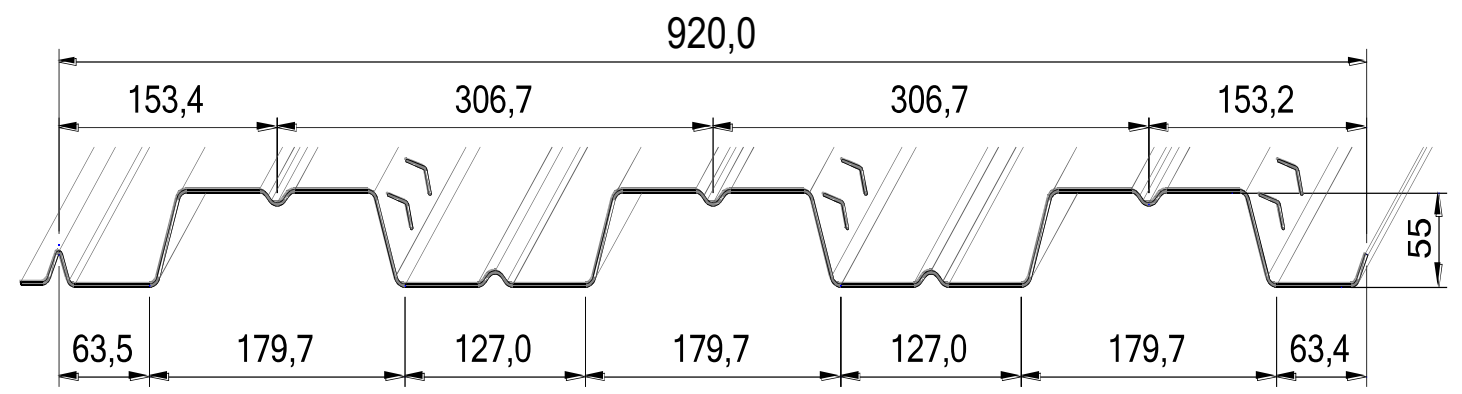

Dimensões em mm

Fonte: Modular (2014)

Cada tipo de perfil apresenta um mecanismo responsável pela transferência dos esforços solicitantes na interface aço-concreto. Em fôrmas trapezoidais, as mossas, saliências estampadas na direção longitudinal das nervuras do perfil, são responsáveis por conferir a ligação mecânica, e consequentemente, pela transmissão de cisalhamento longitudinal. A Figura 4.2 ilustra o padrão de mossas do perfil MD55.

Figura 4. 2. Padrão de mossas do perfil da fôrma de aço modular MD55.

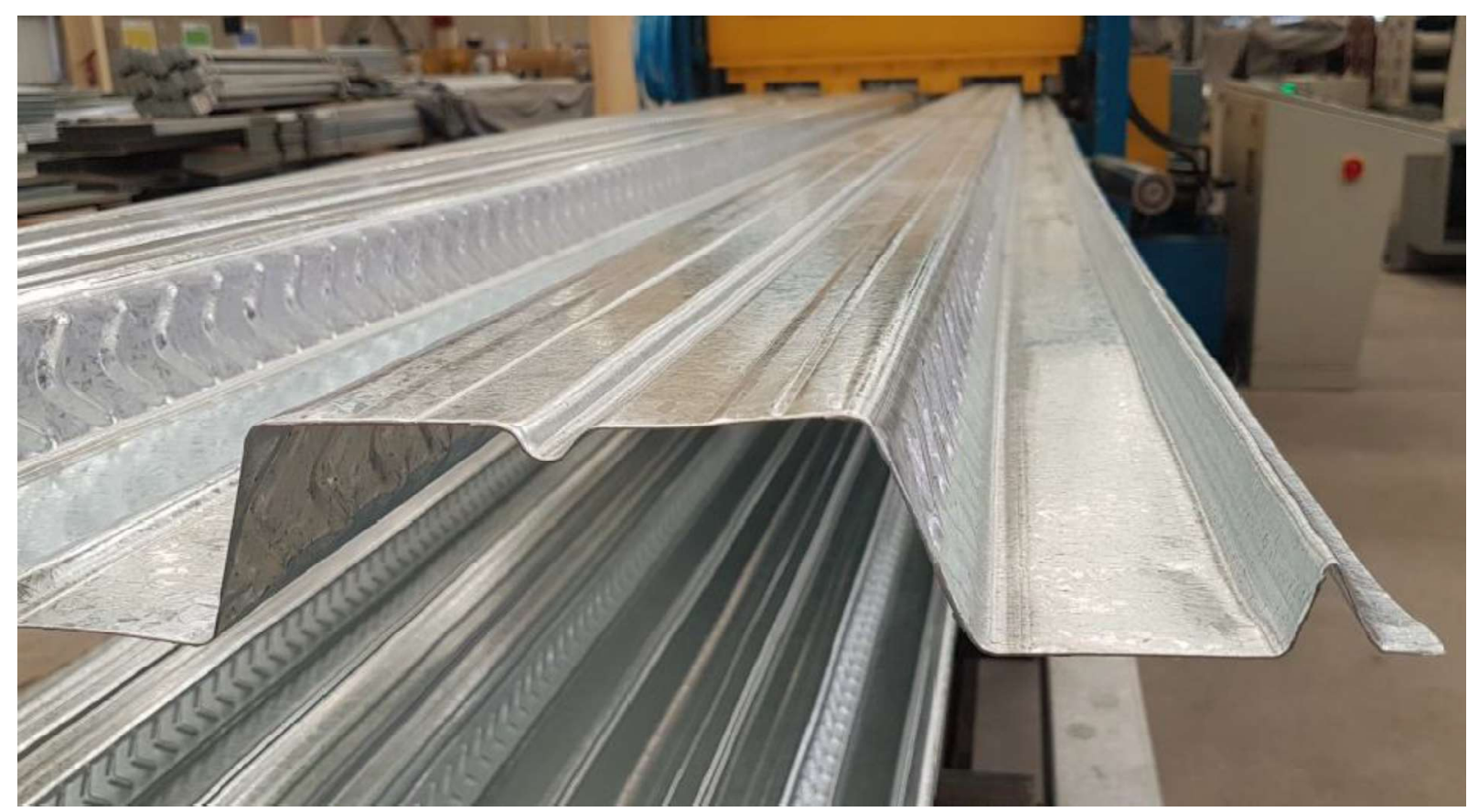

Fonte: Modular (2018) 


\subsubsection{Conectores de cisalhamento}

Os conectores de cisalhamento, presentes nos sistemas usuais de lajes mistas apoiadas em vigas de aço, realizam a ligação entre a fôrma de aço e o concreto, absorvendo os esforços de cisalhamento, além de restringir o movimento vertical entre a laje e a fôrma.

Neste trabalho, foram utilizados dois conectores do tipo pino com cabeça em cada extremidade dos protótipos distantes $100 \mathrm{~mm}$ das extremidades, soldados sobre o perfil de aço (Figura 4.3), com diâmetro de $19 \mathrm{~mm}$ e comprimento total de $105 \mathrm{~mm}$. O aço estrutural utilizado na fabricação desse tipo de conector é o ASTM A108-Grau 1020, com resistência ao escoamento de $345 \mathrm{MPa}$, resistência à ruptura de $415 \mathrm{MPa}$.

Figura 4. 3. Processo de soldagem do conector do tipo pino com cabeça sobre o perfil modular MD55.

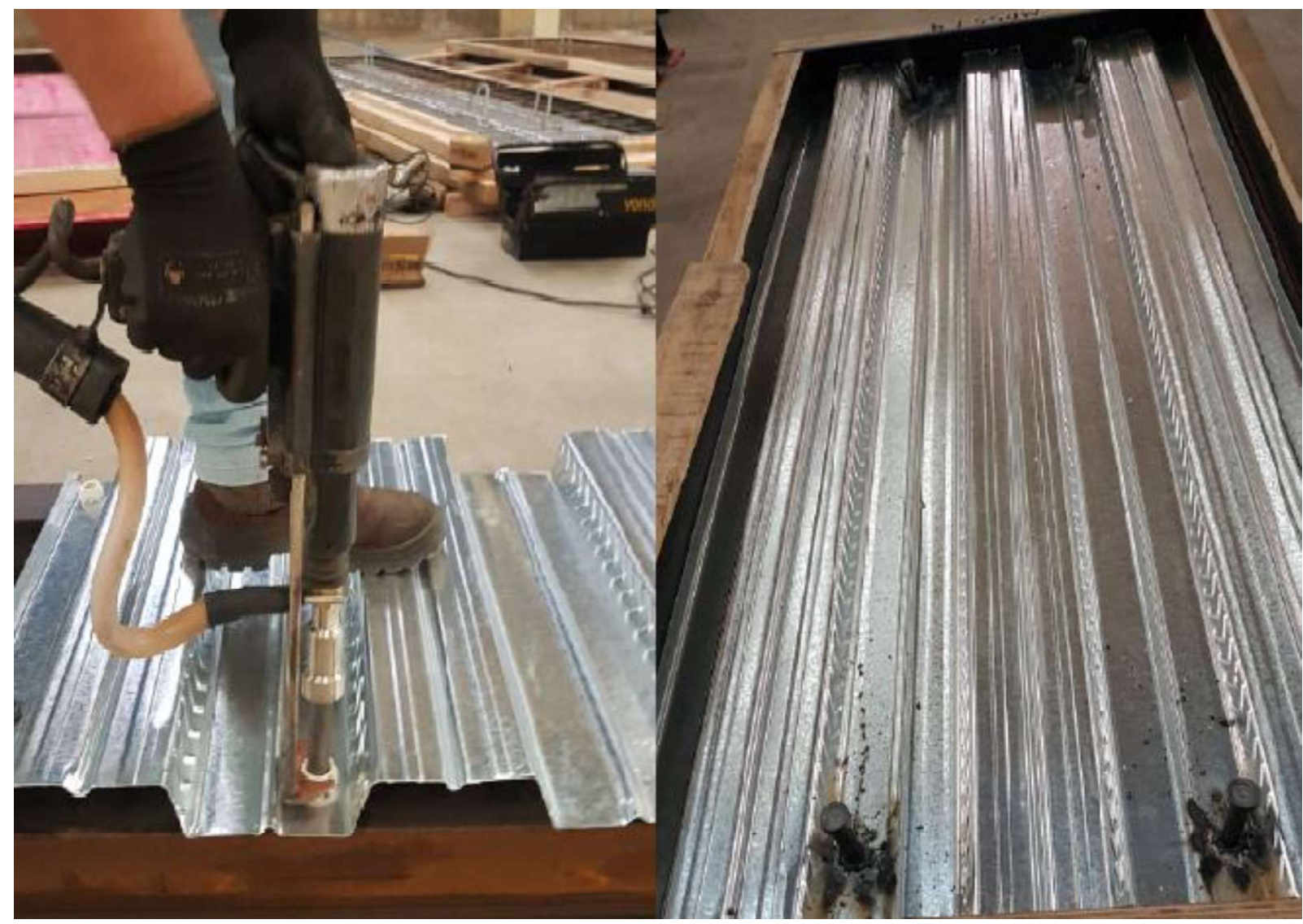

Fonte: Modular (2018) 


\subsubsection{Concreto}

No que diz respeito ao concreto utilizado na confecção das lajes com fôrma de aço incorporada, a ABNT NBR 8800 (2008) não apresenta prescrições específicas, ela apenas faz referência a ABNT NBR 6118 (2014) para a determinação das propriedades do concreto de densidade normal, e cita o EUROCODE 2 Part 1-1 para concretos de baixa densidade, na ausência de norma brasileira aplicável.

De acordo com a ABNT NBR 6118 (2014), os concretos de densidade normal devem apresentar resistência à compressão situada entre $20 \mathrm{MPa}$ e $50 \mathrm{MPa}$, e, massa específica $(\rho \mathrm{c})$ em torno de $2400 \mathrm{~kg} / \mathrm{m}^{3}$ (concreto simples) ou $2500 \mathrm{~kg} / \mathrm{m}^{3}$ (concreto armado). Enquanto que os concretos de baixa densidade devem possuir massa específica $(\rho c)$ situada entre $1500 \mathrm{~kg} / \mathrm{m}^{3}$ e 2200 $\mathrm{kg} / \mathrm{m}^{3}$.

Os dados apresentados na 4.1, correspondem aos valores recomentados pela ABNT NBR 8800 (2008) que deverão ser adotados para fins de projeto para concretos de densidade normal.

Tabela 4. 1. Propriedades mecânicas do concreto de densidade normal de acordo com a ABNT NBR 8800 (2008)

\begin{tabular}{c|c|c|c}
\hline $\begin{array}{c}\text { Módulo tangente } \\
\left.\text { inicial }\left(\mathbf{E}_{\mathbf{c i}}\right) \mathbf{( M P a}\right)\end{array}$ & $\begin{array}{c}\text { Módulo secante }\left(\mathbf{E}_{\mathbf{c i}}\right) \\
\mathbf{( M P a})\end{array}$ & $\begin{array}{c}\text { Coeficiente de dilatação } \\
\text { térmica }\left(\boldsymbol{\beta}_{\mathbf{c}}\right)\left({ }^{\circ} \mathbf{C}^{-\mathbf{1}}\right)\end{array}$ & $\begin{array}{c}\text { Coeficientede } \\
\text { Poisson }\left(\mathbf{v}_{\mathbf{c}}\right)\end{array}$ \\
\hline $5600 \cdot \sqrt{f_{c k}}$ & $0,85 \cdot E_{c i}$ & $10^{-5}$ & 0,2 \\
\hline
\end{tabular}

$f_{c k}$ corresponde à resistência à compressão do concreto, em 28 dias em $\mathrm{MPa}$. 


\subsection{CARACTERÍSTICAS DOS PROTÓTIPOS}

Foram submetidos aos ensaios de flexão de lajes mistas duas séries de protótipos: oito simplesmente apoiados sem ancoragem de extremidade (série L) e dois simplesmente apoiados com conectores de cisalhamento nos apoios (série LC). As variáveis de cada série foram o vão de cisalhamento e a altura das lajes, conforme apresentado nas tabelas 4.2 e 4.3

Tabela 4. 2. Dimensões dos protótipos simplesmente apoiados sem conectores de cisalhamento.

\begin{tabular}{|c|c|c|c|c|c|c|}
\hline Protótipo & $\begin{array}{c}\text { Espessura } \\
\text { nominal da } \\
\text { chapa } t_{n} \\
(\mathbf{m m})\end{array}$ & $\begin{array}{c}\text { Altura } \\
\text { da laje } \\
\mathbf{h}_{\mathbf{t}} \\
(\mathbf{m m}) \\
\end{array}$ & $\begin{array}{c}\text { Largura } \\
\text { da laje } \\
\text { bL }(\mathrm{mm})\end{array}$ & $\begin{array}{c}\text { Comprimento } \\
\text { Lt }_{\mathbf{t}}(\mathbf{m m})\end{array}$ & $\begin{array}{c}\text { Vão } \\
\text { teórico } \\
\text { LF } \\
(\mathrm{mm}) \\
\end{array}$ & $\begin{array}{c}\text { Vão de } \\
\text { cisalhamento } \\
\text { Ls }(\mathbf{m m})\end{array}$ \\
\hline MD55-L1 & \multirow{8}{*}{0,80} & 110 & \multirow{8}{*}{920} & 2.000 & 1.800 & 450 \\
\hline MD55-L2 & & 110 & & 2.000 & 1.800 & 450 \\
\hline MD55-L3 & & 110 & & 2.000 & 1.800 & 450 \\
\hline MD55-L4 & & 110 & & 2.000 & 1.800 & 450 \\
\hline MD55-L5 & & 170 & & 3.800 & 3.600 & 900 \\
\hline MD55-L6 & & 170 & & 3.800 & 3.600 & 900 \\
\hline MD55-L7 & & 170 & & 3.800 & 3.600 & 900 \\
\hline MD55-L8 & & 170 & & 3.800 & 3.600 & 900 \\
\hline
\end{tabular}

Tabela 4. 3. Dimensões dos protótipos simplesmente apoiados com conectores de cisalhamento nos apoios.

\begin{tabular}{|c|c|c|c|c|c|c|}
\hline Protótipo & $\begin{array}{c}\text { Espessura } \\
\text { nominal da } \\
\text { chapa } \mathbf{t}_{\mathbf{n}} \\
(\mathrm{mm}) \\
\end{array}$ & $\begin{array}{c}\text { Altura } \\
\text { da laje } \\
\mathbf{h}_{\mathbf{t}} \\
(\mathrm{mm}) \\
\end{array}$ & $\begin{array}{c}\text { Largura } \\
\text { da laje } \\
\text { bL (mm) }\end{array}$ & $\begin{array}{c}\text { Comprimento } \\
\text { Lt }(\mathbf{m m})\end{array}$ & $\begin{array}{c}\text { Vão } \\
\text { teórico } \\
\text { LF } \\
(\mathbf{m m}) \\
\end{array}$ & $\begin{array}{c}\text { Vão de } \\
\text { cisalhamento } \\
\text { Ls (mm) }\end{array}$ \\
\hline MD55-LC1 & \multirow{2}{*}{0,80} & 110 & \multirow{2}{*}{920} & 2.000 & 1.800 & 450 \\
\hline MD55-LC2 & & 170 & & 3.800 & 3.600 & 900 \\
\hline
\end{tabular}

Com a finalidade de evitar o aparecimento de fissuras oriundas da retração e variação térmica do concreto, foi inserida em todos os protótipos uma armadura de retração na capa de concreto, constituída por tela soldada $\phi 4,2-100 \times 100$ nas lajes com altura total de $170 \mathrm{~mm}$ e $\phi 4,2$ - 150x150 nas lajes com altura total de $110 \mathrm{~mm}$, posicionada a $20 \mathrm{~mm}$ da face superior da laje. 
As Figuras 4.4 e 4.5 apresentam a vista lateral e da seção transversal dos protótipos das séries L e LC, respectivamente.

Figura 4. 4. Vista lateral e seção transversal dos protótipos da série L.

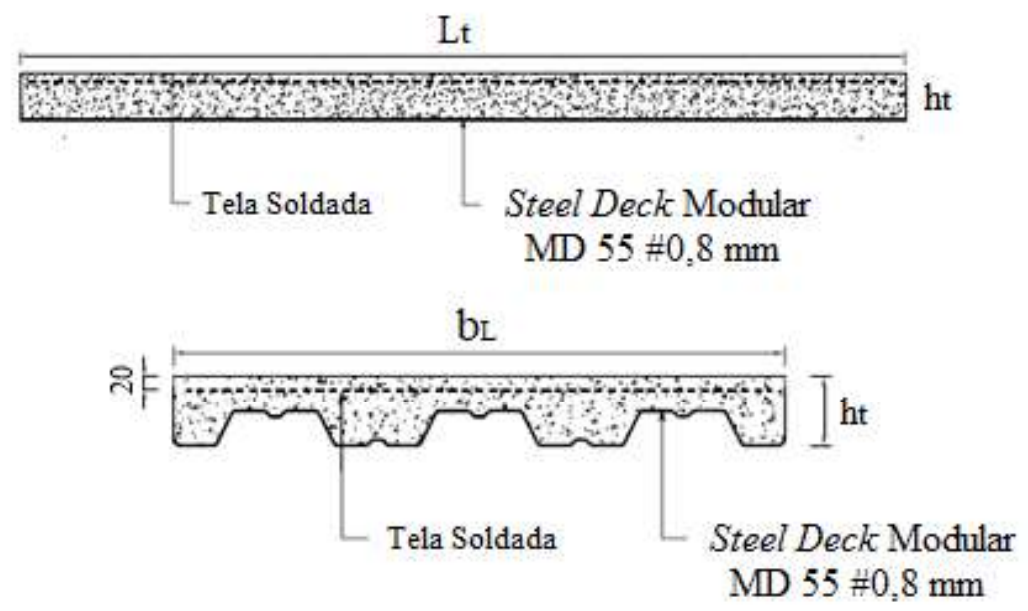

Fonte: Autora (2020)

Figura 4. 5. Vista lateral e seção transversal dos protótipos da série LC.
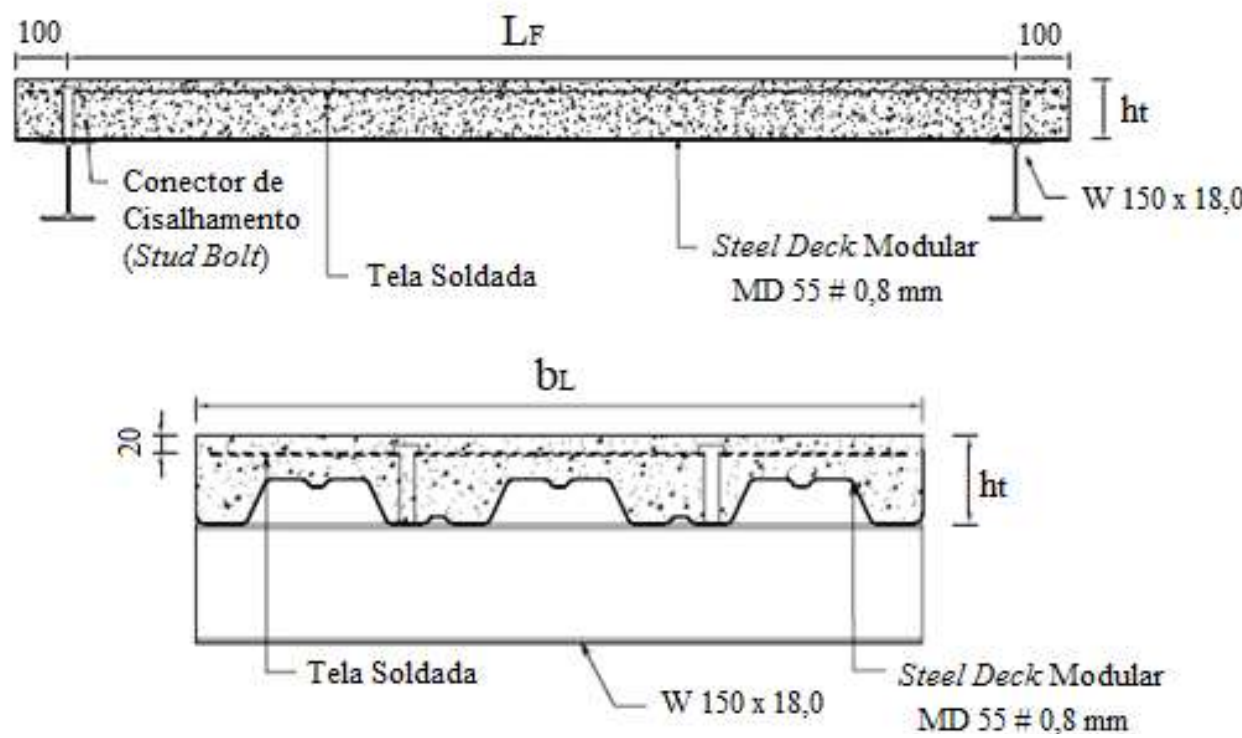

Fonte: Autora (2020) 


\subsection{EQUIPAMENTOS DE ENSAIO E INSTRUMENTAÇÃO}

Para a realização do ensaio de lajes mistas foram utilizados os seguintes equipamentos e instrumentos de medição com suas respectivas funções:

- Atuador servo-hidráulico marca MTS, com capacidade nominal de $500 \mathrm{kN}$ e curso do pistão de 150 mm: aplicação da força;

- Célula de carga e rótula acoplada, com capacidade nominal de $500 \mathrm{kN}$ : medição da força aplicada;

- Transdutores de deslocamento à base de extensômetros, curso de $25 \mathrm{~mm}$, modelo HS25, marca VISHAY: medição do deslizamento longitudinal relativo nas extremidades;

- Transdutor de deslocamento à base de extensômetros, curso de 100 mm, modelo DT-100A, marca KYOWA: medição de deslocamentos verticais;

- Extensômetros elétricos de resistência, modelos KFG-5-120-C1-11 e KFG-10-120-C1-11, marca KYOWA: medição de deformações específicas no aço e no concreto, respectivamente;

- Sistema de aquisição de dados SYSTEM 5000, marca Vishay: aquisição automática das leituras de força, deslocamentos e deformações específicas.

Em todos os protótipos, foram instalados transdutores de deslocamento nas extremidades para medição do deslizamento longitudinal relativo entre o concreto e a fôrma de aço e no meio vão para medição da flecha. As Figuras 4.6 e 4.7 apresentam os transdutores utilizados nos ensaios. 
Figura 4. 6. Transdutor de deslocamento para a medição do deslizamento relativo de extremidade.

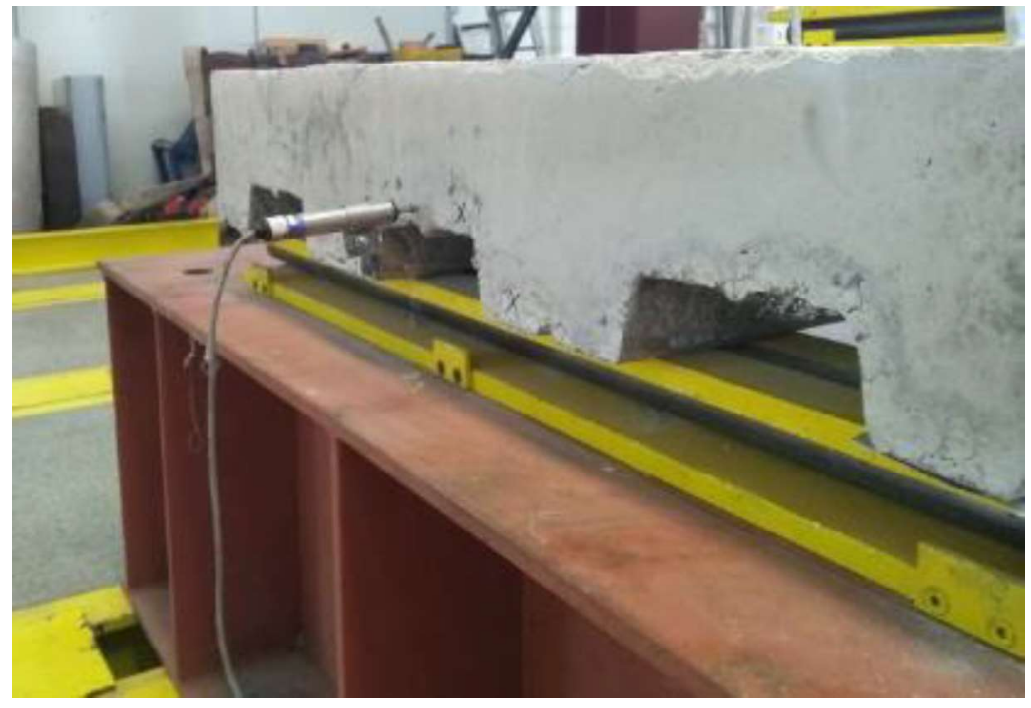

Fonte: Autora (2020)

Figura 4. 7. Transdutor de deslocamento para medição da flecha.

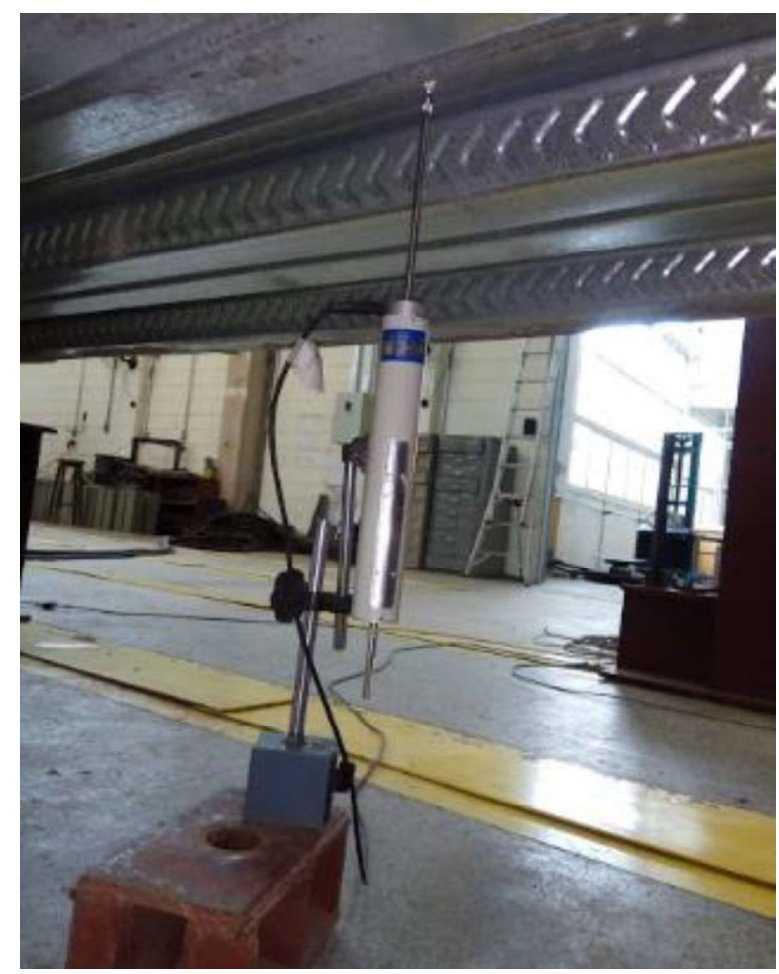

Fonte: Autora (2020) 
Dos protótipos sem conectores de cisalhamento, o MD55L1 e MD55L5 foram instrumentados com extensômetros elétricos uniaxiais para medição de deformações específicas na fôrma de aço e na face superior da capa de concreto, com o objetivo de comparar os dados obtidos com os respectivos protótipos com conectores de cisalhamento, MD55LC1 e MD55LC2, também instrumentados. As Figuras 4.8 e 4.9 mostram os extensômetros na fôrma de aço e na capa de concreto, respectivamente.

Figura 4. 8. Extensômetros elétricos uniaxiais na fôrma de aço (onda alta e onda baixa).

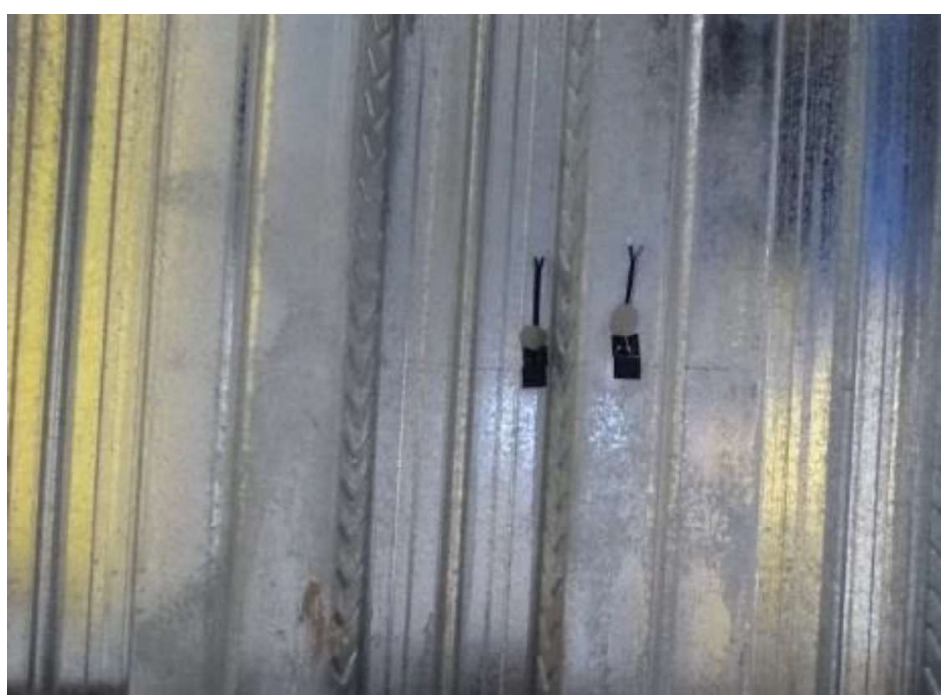

Fonte: Autora (2020)

Figura 4. 9. Extensômetros elétricos uniaxiais na face superior da laje.

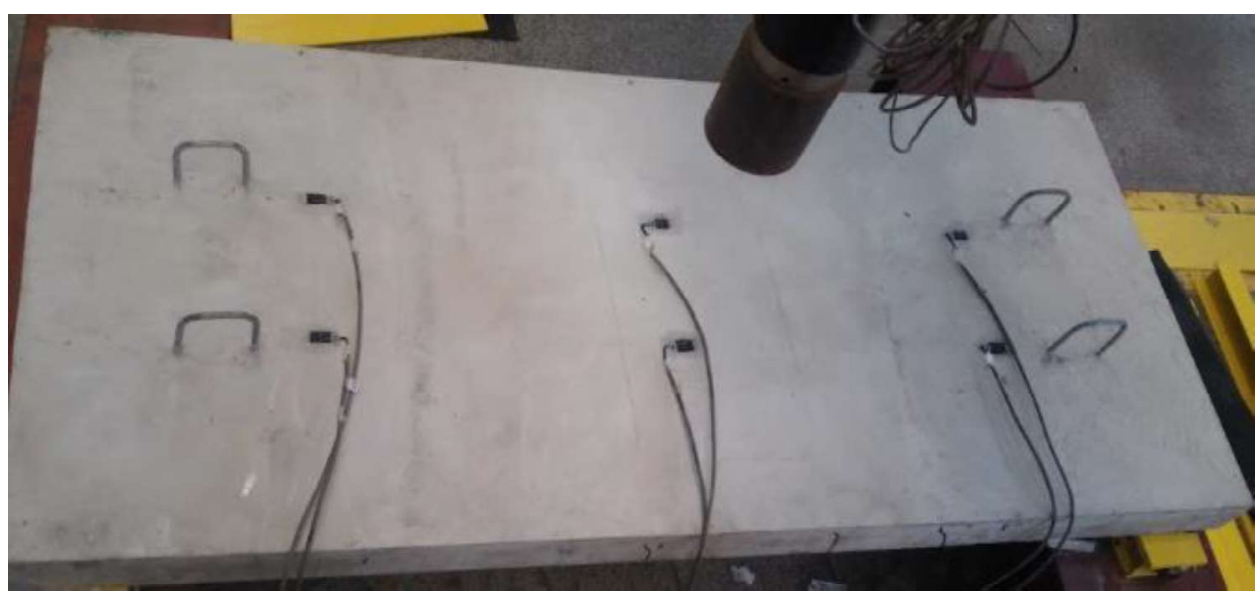

Fonte: Autora (2020) 
Os extensômetros foram posicionados ma seção a meio vão (S2) e em duas seções (S1 e S3), contidas nos vãos de cisalhamento ilustradas na Figura 4.10 e 4.11.

Figura 4. 10. Posição dos extensômetros elétricos.

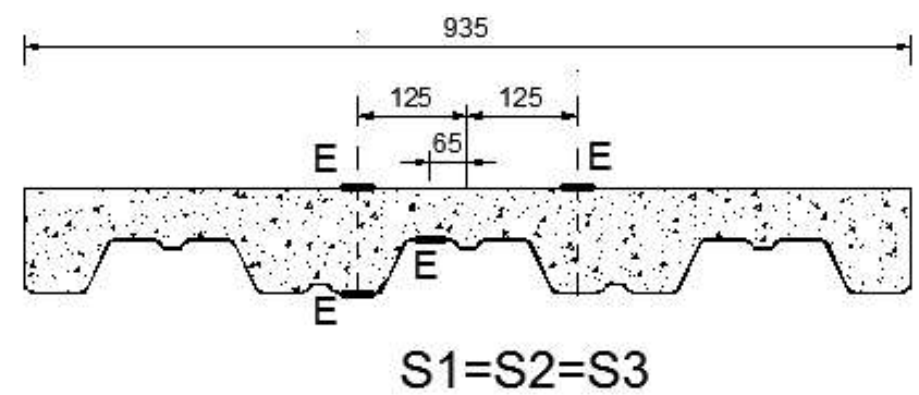

Fonte: Autora (2020)

Figura 4.11. Localização das seções S1, S2 e S3 na direção longitudinal da laje mista.

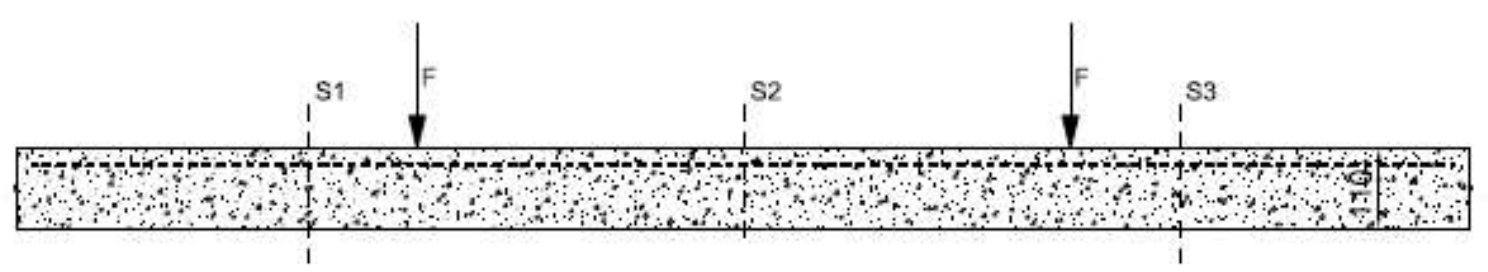

Fonte: Autora (2020)

\subsection{PROCEDIMENTOS DE ENSAIO}

O procedimento de ensaio adotado neste trabalho, com as devidas adaptações, é o recomendado pelo EUROCODE 4 para as lajes mistas, cujo esquema geral de ensaio está apresentado na Figura 2.4. Trata-se de ensaios na condição estática simplesmente apoiada, com duas forças concentradas situadas a L/4 dos apoios, ilustrado nas Figuras 4.11 e 4.12. 
Figura 4.12. Vista geral do protótipo sem conectores de cisalhamento e aparato de ensaio.

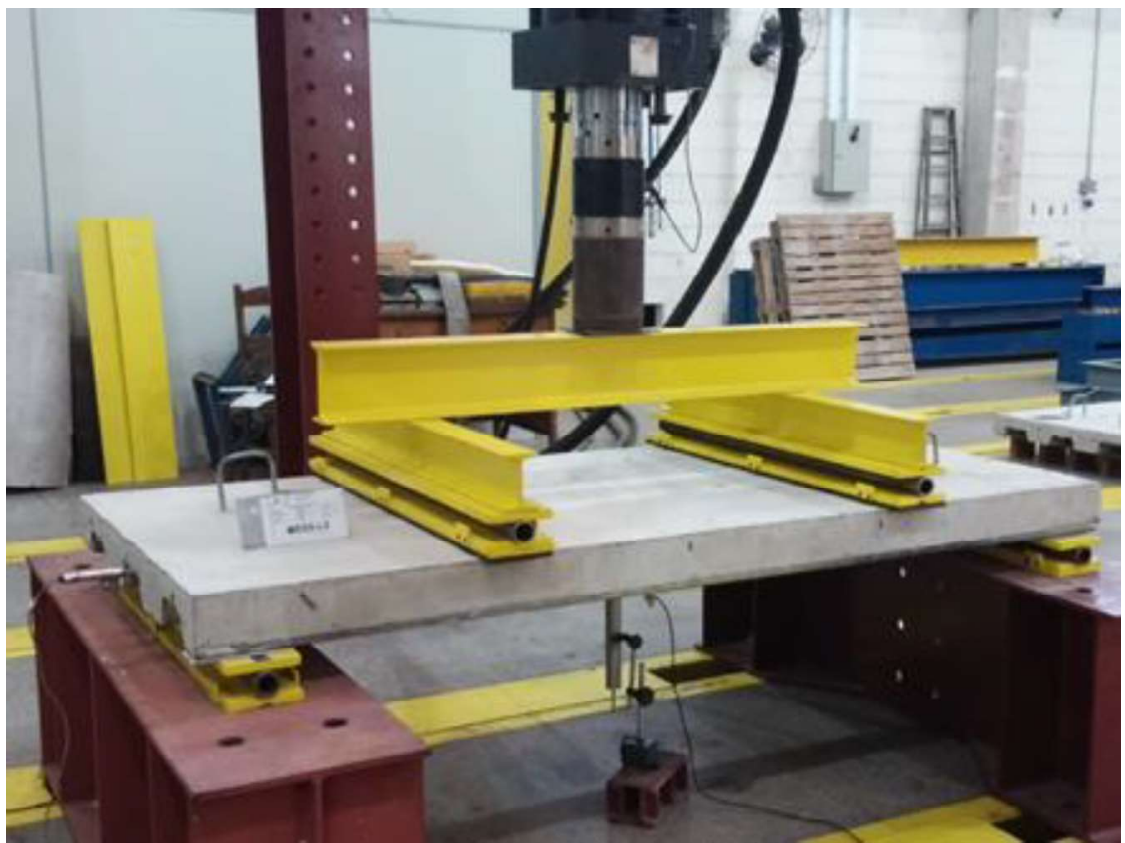

Fonte: Autora (2020)

Figura 4. 13. Vista geral do protótipo com conectores de cisalhamento e aparato de ensaio.

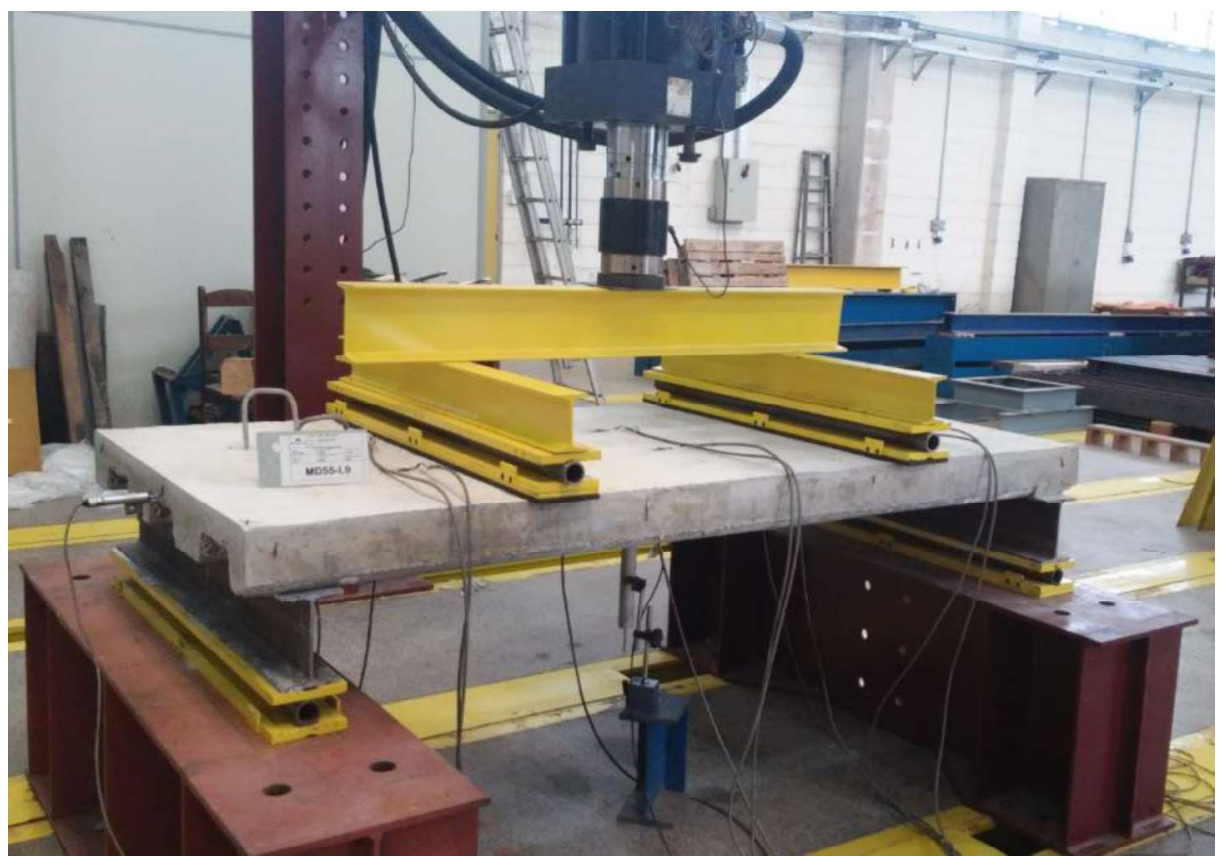

Fonte: Autora (2020) 
Todos os ensaios foram conduzidos com controle de deslocamento do pistão do atuador (taxa variando de $0,01 \mathrm{~mm} / \mathrm{s}$ a $0,05 \mathrm{~mm} / \mathrm{s}$ ). Foi inicialmente aplicada uma força de $4 \mathrm{kN}$, seguida de descarregamento, para acomodação do protótipo e aparato de ensaio, bem como verificação dos instrumentos de medição. Em seguida, as leituras foram zeradas e foi realizado o ensaio propriamente dito, até o esgotamento da capacidade do sistema. A força, os deslocamentos e as deformações específicas foram registrados automaticamente via sistema de aquisição de dados, a uma taxa de um registro por segundo.

Os resultados obtidos dos ensaios, bem como a análise da influência dos conectores de cisalhamento no comportamento das lajes mistas são apresentados no capítulo a seguir. 


\section{RESULTADOS EXPERIMENTAIS: INFLUENCIA DOS CONECTORES DE CISALHAMENTO}

Este capítulo apresenta os resultados provenientes dos ensaios detalhados no capítulo anterior.

Será analisado o comportamento do sistema de lajes mistas com e sem conectores de cisalhamento do tipo pino com cabeça, nos apoios, por meio das curvas força $\mathrm{x}$ flecha, força $\mathrm{x}$ deslizamento relativo de extremidade, força $\mathrm{x}$ deformação no aço e força $\mathrm{x}$ deformação no concreto. As curvas referentes a todos os protótipos ensaiados encontram-se no apêndice B.

Além disso, comparações serão feitas entre os resultados oriundos dos protótipos com e sem ancoragem de extremidade.

\subsection{PROPRIEDADES MECÂNICAS DOS MATERIAIS}

As propriedades mecânicas do aço das fôrmas foram determinadas com base em ensaios de tração, seguindo os procedimentos da ASTM A370-14 (2014), em nove corpos de prova, extraídos de três amostras da bobina empregada na fabricação das fôrmas fornecidas pela Modular Sistema Construtivo. Conforme informado por esta empresa, as chapas são de especificação ABNT NBR 7008 - ZAR 280 e espessura nominal de $0,80 \mathrm{~mm}$.

A Tabela 5.1 contém os valores da resistência ao escoamento $\left(f_{y}\right)$, da resistência à ruptura $\left(f_{u}\right)$ e do alongamento na ruptura $(A)$. O valor do módulo de elasticidade do aço $\left(\mathrm{E}_{\mathrm{a}}\right)$ adotado foi o convencional de $200.000 \mathrm{MPa}$.

Tabela 5. 1. Propriedades mecânicas do aço das fôrmas

\begin{tabular}{c|c|c|c}
\hline Corpo de prova & $\mathbf{f}_{\mathbf{y F}}(\mathbf{M P a})^{\mathbf{a}}$ & $\mathbf{f}_{\mathbf{u F}} \mathbf{( M P a}^{\mathbf{b}}$ & \multicolumn{2}{|c}{ Alongamento (\%) ${ }^{\mathbf{c}, \mathbf{d}}$} \\
\hline 1 & \multicolumn{3}{|c}{ Falha na aquisição de dados } \\
\hline 2 & 328 & 431 & 32 \\
\hline 3 & 332 & 440 & 32 \\
\hline 4 & 326 & 439 & 32 \\
\hline 5 & 328 & 439 & 32 \\
\hline 6 & 328 & 440 & 32 \\
\hline 7 & 334 & 441 & 32 \\
\hline 8 & 330 & 440 &
\end{tabular}




\begin{tabular}{c|c|c|c}
\hline 9 & 328 & 439 & Ruptura fora da base de medida \\
\hline Média & $\mathbf{3 2 9}$ & $\mathbf{4 3 9}$ & $\mathbf{3 1 , 7}$ \\
\hline
\end{tabular}

${ }^{a}$ Segundo a ABNT NBR 7008-3 (2012), $\mathrm{f}_{\mathrm{yF}} \geq 280 \mathrm{Mpa}$;

${ }^{\text {b }}$ Segundo a ABNT NBR 7008-3 (2012), $\mathrm{f}_{\mathrm{uF}} \geq 380 \mathrm{Mpa}$;

${ }^{\mathrm{c}}$ Base de medida: $50 \mathrm{~mm}$;

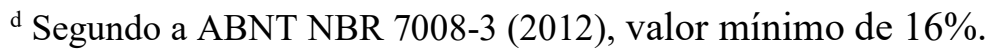

Fonte: Autora (2020)

O concreto utilizado em todos os protótipos foi dosado e misturado em usina, com resistência característica à compressão especificada $f_{c k}=25 \mathrm{MPa}$.

As propriedades mecânicas foram determinadas com base em ensaios de compressão em corpos-de-prova cilíndricos $10 \times 20(\mathrm{~cm})$. A resistência à compressão $\left(f_{c}\right)$ e o módulo de elasticidade inicial $\left(E_{c i}\right)$ foram determinados seguindo às especificações da ABNT NBR 5739 (2007) e ABNT NBR 8522 (2008), respectivamente.

$\mathrm{Na}$ Tabela 5.2 são apresentados os valores da resistência à compressão $\left(f_{c}\right)$ e dos módulos de elasticidade inicial $\left(E_{c i}\right)$ e secante $\left(E_{c}\right)$.

Tabela 5. 2. Propriedades mecânicas do concreto ${ }^{\mathrm{a}}$.

\begin{tabular}{c|c|c|c}
\hline Corpo de prova & $\boldsymbol{f}_{\boldsymbol{c}}(\mathbf{M P a})$ & $\boldsymbol{E}_{\boldsymbol{c} \boldsymbol{i}}(\mathbf{M P a})^{\mathbf{b}}$ & $\boldsymbol{E}_{\boldsymbol{c}}(\mathbf{M P a})^{\mathbf{c}}$ \\
\hline 1 & 35,90 & 21.968 & 18.892 \\
\hline 2 & 40,44 & 19.264 & 16.567 \\
\hline 3 & 38,14 & 21.627 & 18.599 \\
\hline 4 & 37,02 & 18.760 & 16.133 \\
\hline 5 & 34,98 & 18.764 & 16.137 \\
\hline 6 & 32,23 & 21.916 & 18.847 \\
\hline Média & 36,45 & 20.383 & 17.529 \\
\hline
\end{tabular}

${ }^{\text {a }}$ Idade do concreto no dia dos ensaios de compressão: 40 dias

${ }^{\mathrm{b}}$ Módulo de elasticidade inicial. Segundo a ABNT NBR 8522 (2008), refere-se ao módulo cordal entre $0,5 \mathrm{MPa}$ e $0,3 f_{c}$

${ }^{\mathrm{c}}$ Módulo de deformação secante. Segundo a ABNT NBR 6118 (2014), pode ser obtido por $\mathrm{E}_{\mathrm{c}}=\alpha_{\mathrm{i}} \mathrm{E}_{\mathrm{ci}}$, sendo $\alpha_{\mathrm{i}}=0,86$ para concretos classe $\mathrm{C} 25$ 


\subsection{COMPORTAMENTO DAS LAJES MISTAS SEM CONECTORES DE CISALHAMENTO}

Na Tabela 5.3 apresentam-se os valores de força de todos os protótipos sem conectores de cisalhamento e suas respectivas classificações como dúctil ou frágil.

Tabela 5. 3. Resultados experimentais dos protótipos sem conectores de cisalhamento.

(continua)

\begin{tabular}{c|c|c|c|c|c|c}
\hline Protótipo & $\begin{array}{c}\mathbf{F}_{\text {des }}{ }^{\mathbf{2}} \\
(\mathbf{k N})\end{array}$ & $\begin{array}{c}\mathbf{F}_{\mathbf{m a x}}{ }^{\mathbf{b}} \\
(\mathbf{k N})\end{array}$ & $\begin{array}{c}\mathbf{F}_{\text {total }} \mathbf{c}^{\mathbf{c}} \\
\mathbf{( k N )}\end{array}$ & $\mathbf{F}_{\mathbf{m a x}} / \mathbf{F}_{\text {des }} \mathbf{d}^{\mathbf{d}}$ & Comportamento & $\begin{array}{c}\mathbf{V}_{\mathbf{t}}{ }^{\mathbf{e}} \\
(\mathbf{k N})\end{array}$ \\
\hline MD55-L1 & 39,4 & 39,4 & 44,7 & 1,0 & Frágil & $\mathbf{1 7 , 8 8}$ \\
\hline MD55-L2 & 48,2 & 48,2 & 53,5 & 1,0 & Frágil & $\mathbf{2 1 , 4 0}$ \\
\hline MD55-L3 & 51,3 & 51,3 & 56,6 & 1,0 & Frágil & $\mathbf{2 2 , 6 4}$ \\
\hline MD55-L4 & 51,5 & 51,5 & 56,8 & 1,0 & Frágil & $\mathbf{2 2 , 7 2}$ \\
\hline
\end{tabular}

Tabela 5.3. Resultados experimentais dos protótipos sem conectores de cisalhamento.

(conclusão)

\begin{tabular}{c|c|c|c|c|c|c}
\hline Protótipo & $\begin{array}{c}\mathbf{F}_{\text {des }}{ }^{\mathbf{a}} \\
(\mathbf{k N})\end{array}$ & $\begin{array}{c}\mathbf{F}_{\mathbf{m a x}}{ }^{\mathbf{b}} \\
\mathbf{( k N )}\end{array}$ & $\begin{array}{c}\mathbf{F}_{\text {total }}{ }^{\mathbf{c}} \\
\mathbf{( k N )}\end{array}$ & $\mathbf{F}_{\mathbf{m a x}} / \mathbf{F}_{\text {des }}{ }^{\mathbf{d}}$ & Comportamento & $\begin{array}{c}\mathbf{V}_{\mathbf{t}}{ }^{\mathbf{e}} \\
(\mathbf{k N})\end{array}$ \\
\hline MD55-L5 & 34,6 & 34,6 & 49,3 & 1,0 & Frágil & $\mathbf{1 9 , 7 2}$ \\
\hline MD55-L6 & 36,4 & 36,4 & 51,1 & 1,0 & Frágil & $\mathbf{2 0 , 4 4}$ \\
\hline MD55-L7 & 18,5 & 22,4 & - & - & - & - \\
\hline MD55-L8 & 29,0 & 29,0 & 43,7 & 1,0 & Frágil & $\mathbf{1 7 , 4 8}$ \\
\hline
\end{tabular}

${ }^{a} F_{\text {des }}$ é a força associada ao início de deslizamento relativo entre a fôrma de aço e o concreto nas extremidades.

${ }^{\mathrm{b}} \mathrm{F}_{\max }$ é a máxima força aplicada (peak load);

${ }^{\mathrm{c}} \mathrm{F}_{\text {total }}$ é a máxima força aplicada acrescida do peso próprio do protótipo $\left(\mathrm{P}_{\text {prot }}\right)$ e dos 


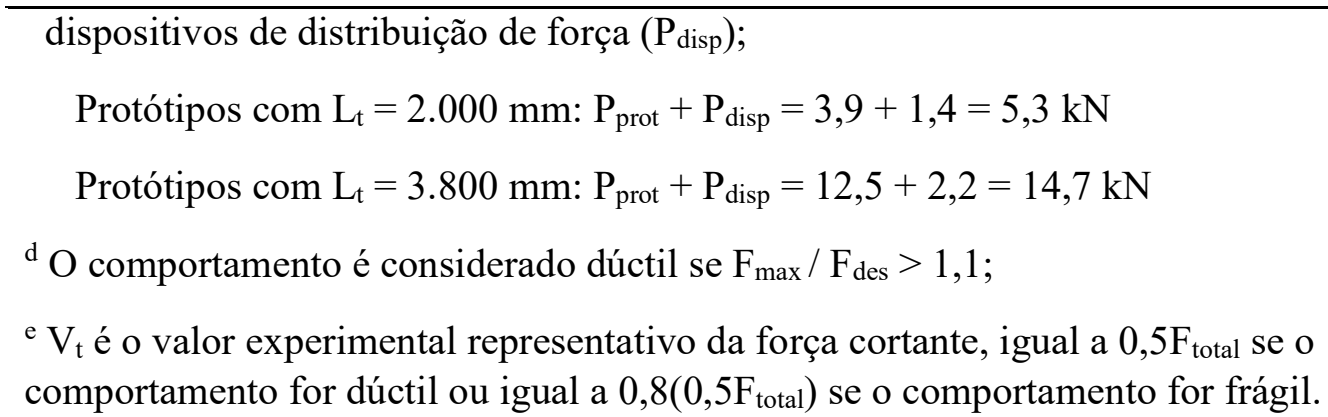

Fonte: Autora (2020)

Do protótipo MD55-L1 ao MD55-L6, o comportamento estrutural apresentado foi o comportamento geral das lajes mistas sob flexão descrito no item 3.4. Assim, ocorreu brusco deslizamento relativo entre a fôrma de aço e o concreto em uma das extremidades, precedido por fissuras iniciadas na região de aplicação de força e do lado em que ocorreu o deslizamento.

Ao ocorrer o deslizamento relativo (Figura 5.1), a força aplicada pelo atuador apresentou queda significativa, e as fissuras se propagaram rapidamente até a posição da tela soldada (Figura $5.2)$.

Figura 5. 1. Deslizamento relativo entre o concreto e a fôrma de aço na extremidade.

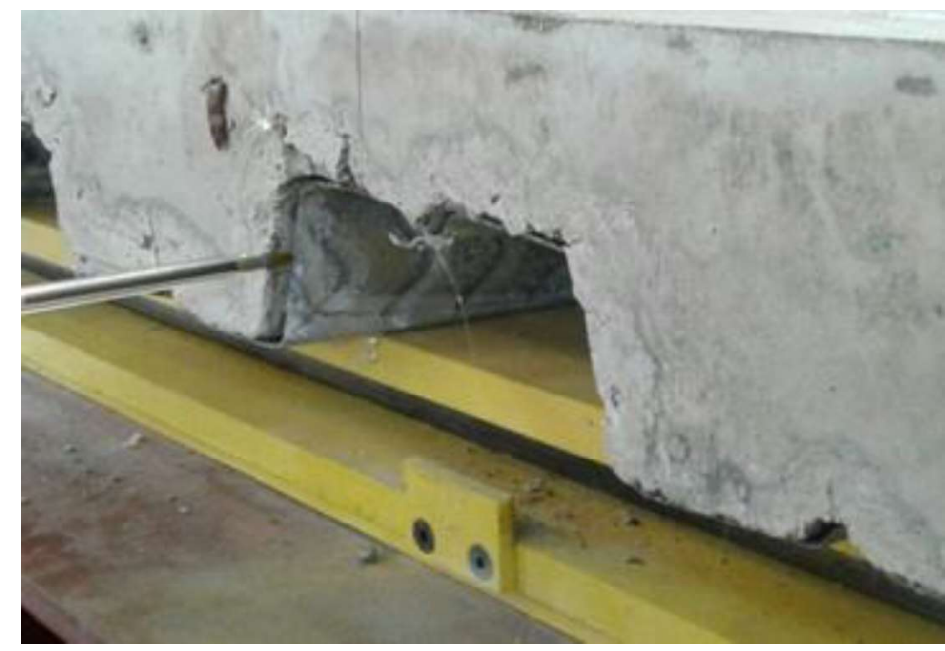

Fonte: Autora (2020) 
Figura 5. 2. Aspecto da fissura na região da força aplicada após o deslizamento.

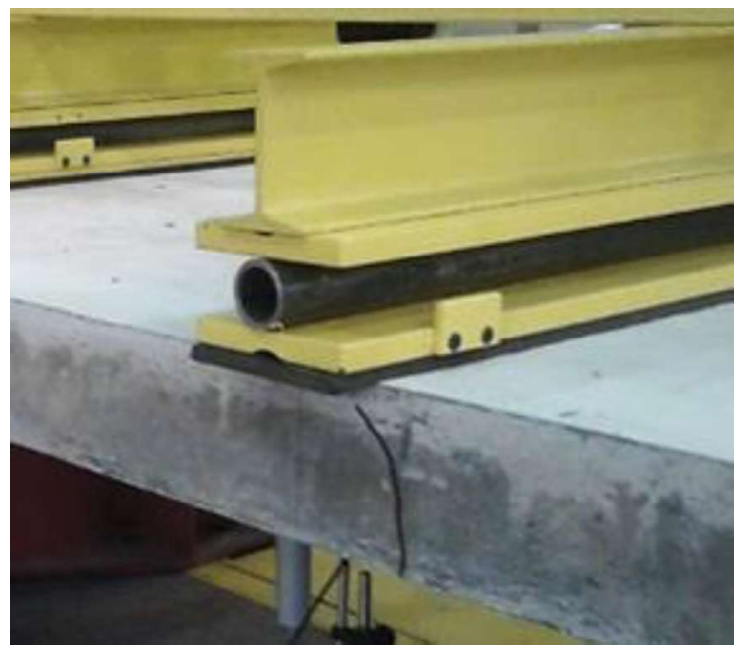

Fonte: Autora (2020)

Os protótipos MD55-L7 e MD55-L8 apresentaram comportamento atípico com a fissura tendo início no meio do vão. Nesses protótipos, após investigação, foi identificado que parte da fôrma de aço, ao longo de uma das faces laterais, apresentava descolamento (Figura 5.3), comportando-se nessa região possivelmente como laje de concreto sem armadura. Como consequência, a laje perdeu capacidade, precipitando o início de deslizamento.

Figura 5. 3. Fôrma descolada na lateral do protótipo MD55-L7.

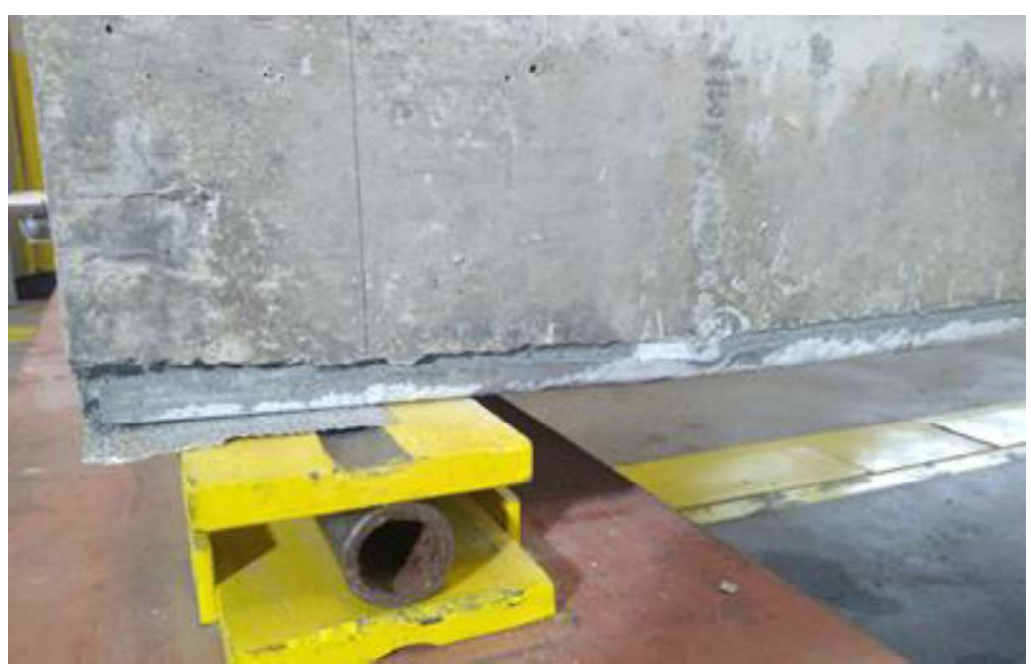

Fonte: Autora (2020) 
Todos os protótipos sem ancoragem de extremidade apresentaram comportamento frágil, uma vez que a força máxima alcançada no ensaio foi aquela que gerou o deslizamento relativo.

O apêndice A apresenta um relatório fotográfico dos ensaios.

Comportamento Força x Deslizamento Relativo de Extremidade

Os gráficos das Figuras 5.4 e 5.5 mostram as curvas força $\mathrm{x}$ deslizamento relativo de extremidade dos protótipos MD55-L2 e MD55-L5, respectivamente, representando todos os protótipos sem conectores de cisalhamento para a análise do comportamento feita a seguir.

Figura 5. 4. Curva Força x Deslizamento Relativo do protótipo MD55-L2.

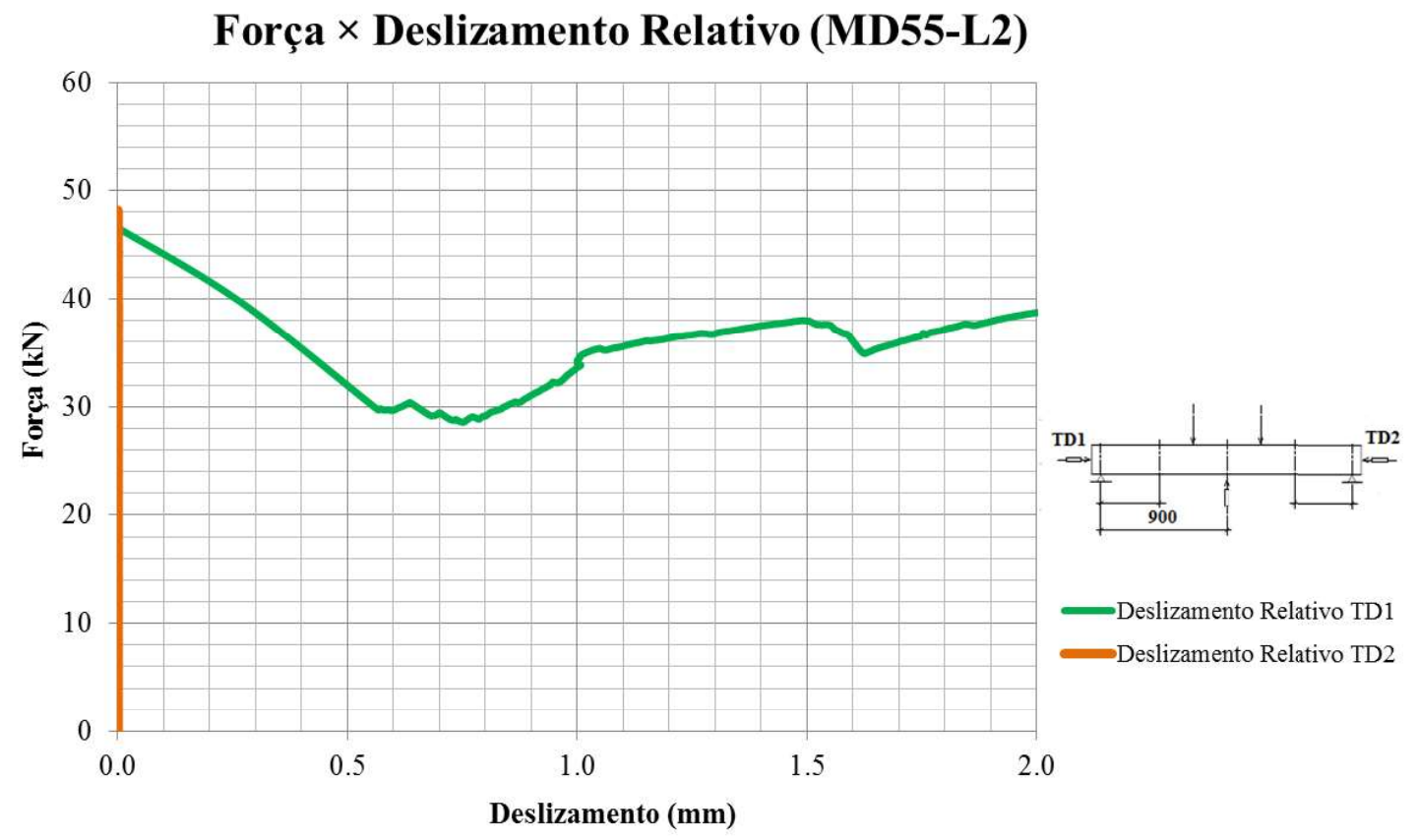

Fonte: Autora (2020) 
Figura 5. 5. Curva Força x Deslizamento Relativo do protótipo MD55-L5.

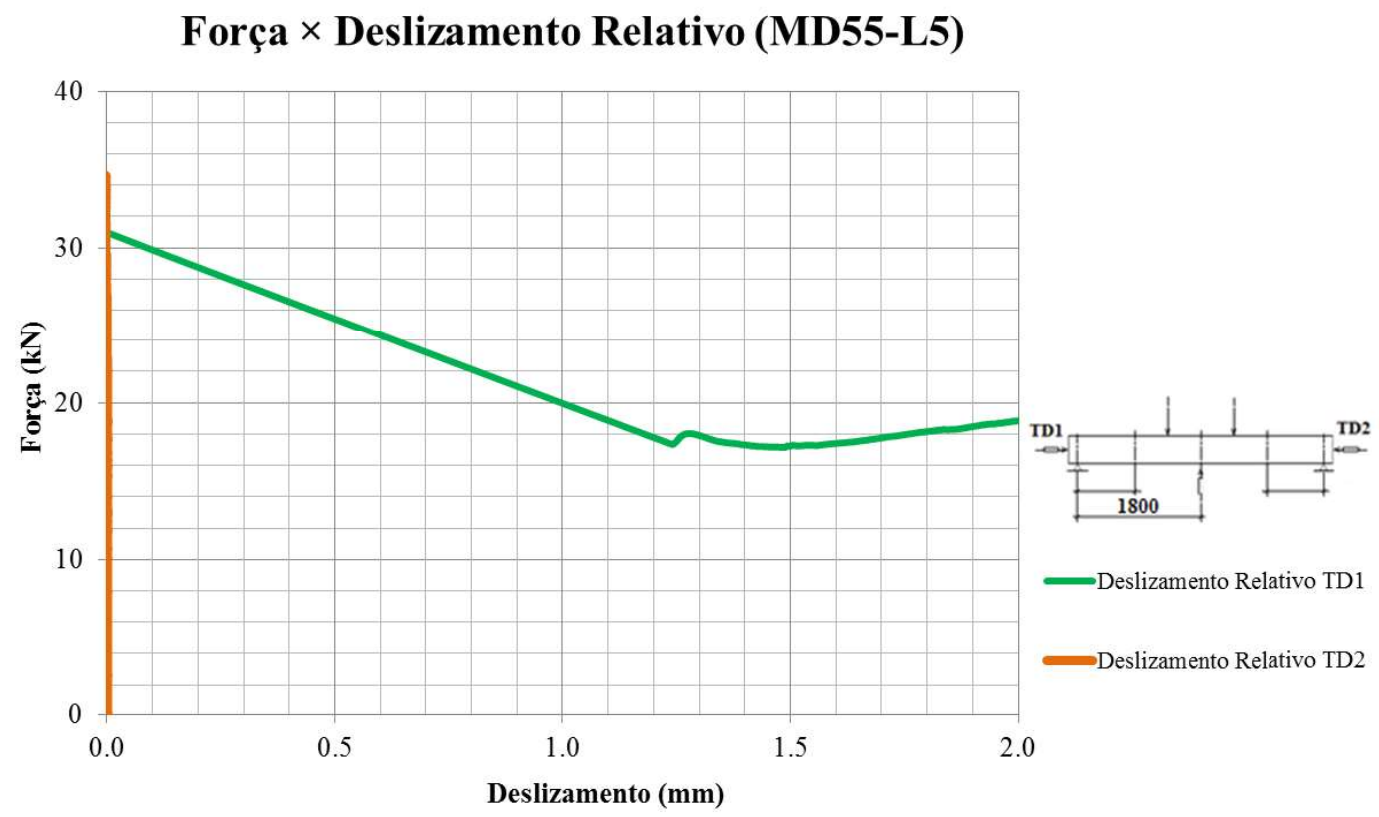

Fonte: Autora (2020)

De acordo com os gráficos das Figuras 5.4 e 5.5, inicialmente, o deslizamento relativo de extremidade é praticamente inexistente, uma vez que a fôrma de aço e o concreto encontram-se em interação completa. Neste estágio, o principal fator responsável por este comportamento é a ligação química proveniente da aderência natural entre os materiais, a qual ao ser rompida, origina fissuras na região de aplicação da força, acarretando na perda da ação composta entre o concreto e a fôrma de aço no vão de cisalhamento e a queda significativa da força aplicada pelo atuador. Neste novo estágio, a interação ao cisalhamento longitudinal passa a ser parcial, sendo as mossas e o atrito nos apoios os mecanismos responsáveis pela resistência ao deslizamento relativo entre a fôrma de aço e o concreto.

Comportamento Força x Flecha

O gráfico da Figura 5.6 apresenta as curvas força $\mathrm{x}$ flecha experimental para todos os protótipos sem conectores de cisalhamento. 
Figura 5. 6. Curvas Força x Flecha Experimental de todos os protótipo sem conectores de cisalhamento.

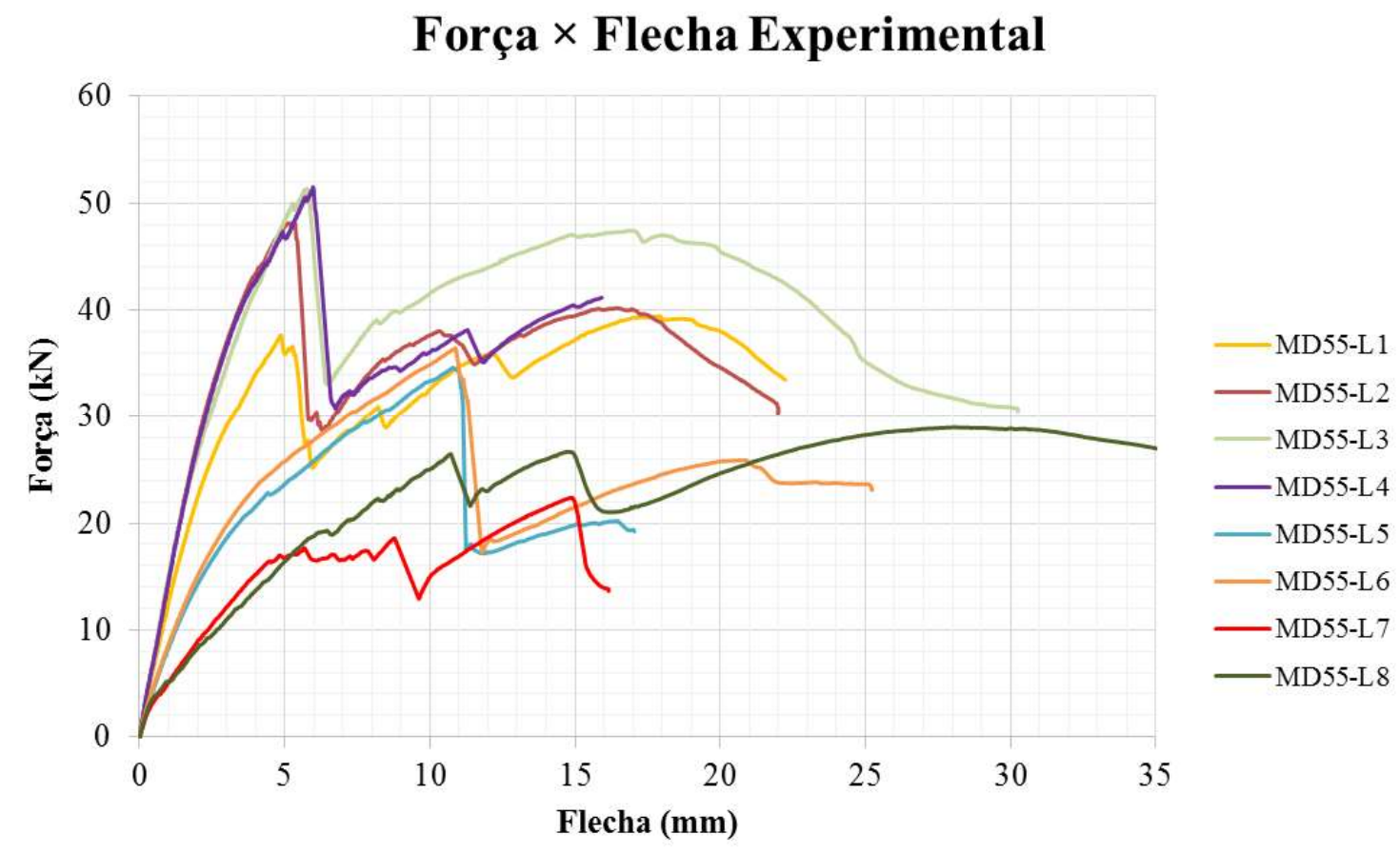

Fonte: Autora (2020)

Os gráficos das Figuras 5.7 e 5.8 referem-se as curvas força $\mathrm{x}$ flecha dos protótipos representativos MD55-L2 e MD55-L5 para a análise do comportamento. 
Figura 5. 7. Curva Força x Flecha do protótipo MD55-L2.

\section{Força x Flecha (MD55-L2)}

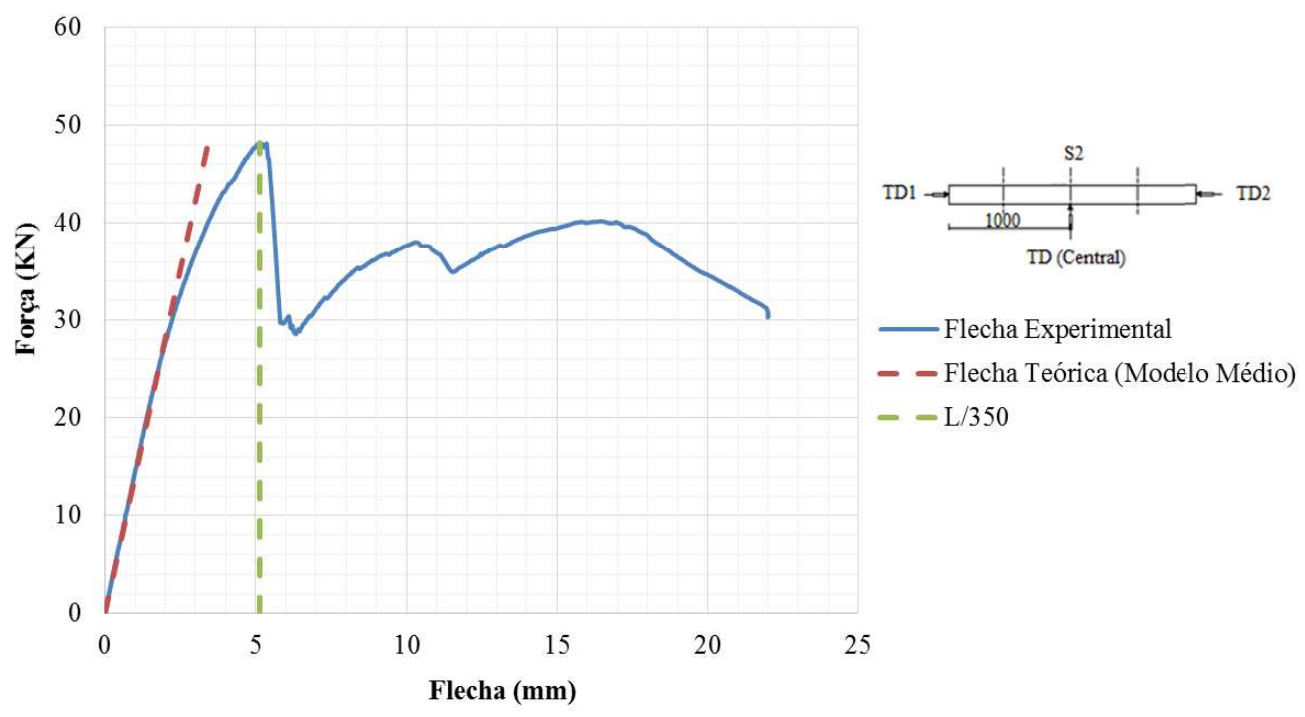

Fonte: Autora (2020)

Figura 5. 8. Curva Força x Flecha do protótipo MD55-L5.

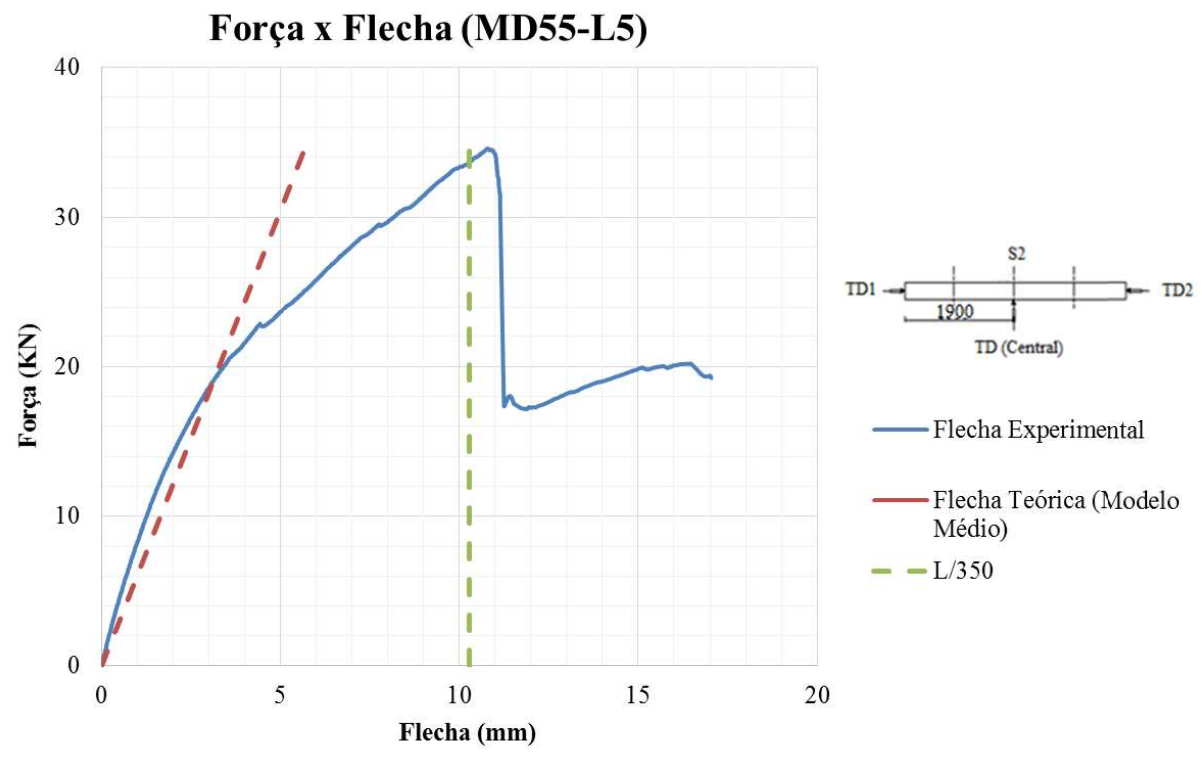

Fonte: Autora (2020)

A ABNT NBR 8800 (2008) é omissa no que diz respeito ao cálculo do momento de inércia da seção mista necessário para a determinação dos deslocamentos verticais teóricos. Neste trabalho, 
as flechas teóricas, expostas nas curvas dos gráficos das Figuras 5.7 e 5.8, foram calculadas com base na média dos momentos de inércia considerando o concreto não fissurado e concreto fissurado, por meio da equação 5.1 .

$$
\delta=\frac{11 L_{F}^{3}}{768 E I_{m}}(F)
$$

O apêndice B mostra as expressões e valores encontrados para todos os protótipos. Todas as expressões aqui utilizadas podem ser encontradas no ANSI/ASCE 3-91 e no CSSBI S2-2008 e em Grossi (2016). Além disso, os Gráficos mostram a reta referente ao limite imposto pela ABNT NBR 8800 (2008) para o máximo deslocamento vertical das lajes mistas de aço e concreto, considerando somente as ações variáveis: $\delta_{\text {máx }} \leq L_{F} / 350$, sendo $L_{F}$ o vão teórico.

Observa-se no comportamento das curvas força $\mathrm{x}$ flecha, representadas nos gráficos das Figuras 5.7 e 5.8, que à medida que a força foi aumentada foram identificados os estágios não fissurado e fissurado. No primeiro, não há o aparecimento de fissuras visíveis no concreto e os resultados teóricos se aproximam dos resultados experimentais. Neste estágio, a seção permaneceu com interação total. Com o surgimento da fissura inicial, identifica-se a mudança de rigidez do protótipo e a curva força $\mathrm{x}$ flecha deixa de ser linear. Desta forma, os valores teóricos deixam de ter uma boa correlação com os valores experimentais. Devido a presença dos mecanismos de transferência de cisalhamento (mossas e atrito), as curvas apresentaram um ajuste após a queda da força aplicada, indicando a mudança de interação total para parcial.

De acordo com o EUROCODE 4 (2004), o comportamento do sistema de laje mista pode ser classificado em dúctil ou frágil por meio da curva força x flecha. O comportamento é classificado como dúctil se a força última excede a força que causa o deslizamento de extremidade inicial de $0,1 \mathrm{~mm}$ em mais que $10 \%$. Todos os protótipos ensaiados apresentaram um comportamento frágil, o que pode ser verificado pelos resultados mostrados na Tabela $5.3 \mathrm{e}$ observando-se as curvas força $\mathrm{x}$ flecha contidas no apêndice $\mathrm{B}$. 
Comportamento Força x Deformação no aço e Força x Deformação no concreto

Todas as curvas força $\mathrm{x}$ deformação referentes aos protótipos instrumentados encontramse no apêndice B.

Os gráficos das Figuras 5.9 e 5.11 apresentam as curvas força x deformação no aço para os protótipos MD55-L1 e MD55-L5, respectivamente, relativas à seção contida na região onde ocorreu o deslizamento relativo. Os gráficos das Figuras 5.10 e 5.12 apresentam as deformações no concreto referentes à mesma seção. Os valores positivos indicam tração e os valores negativos indicam compressão.

Figura 5. 9. Curvas Força x Deformação na fôrma de aço na seção S3 do protótipo MD55-L1.

\section{Força x Deformação na Fôrma de Aço: Seção S3}

(MD55-L1)

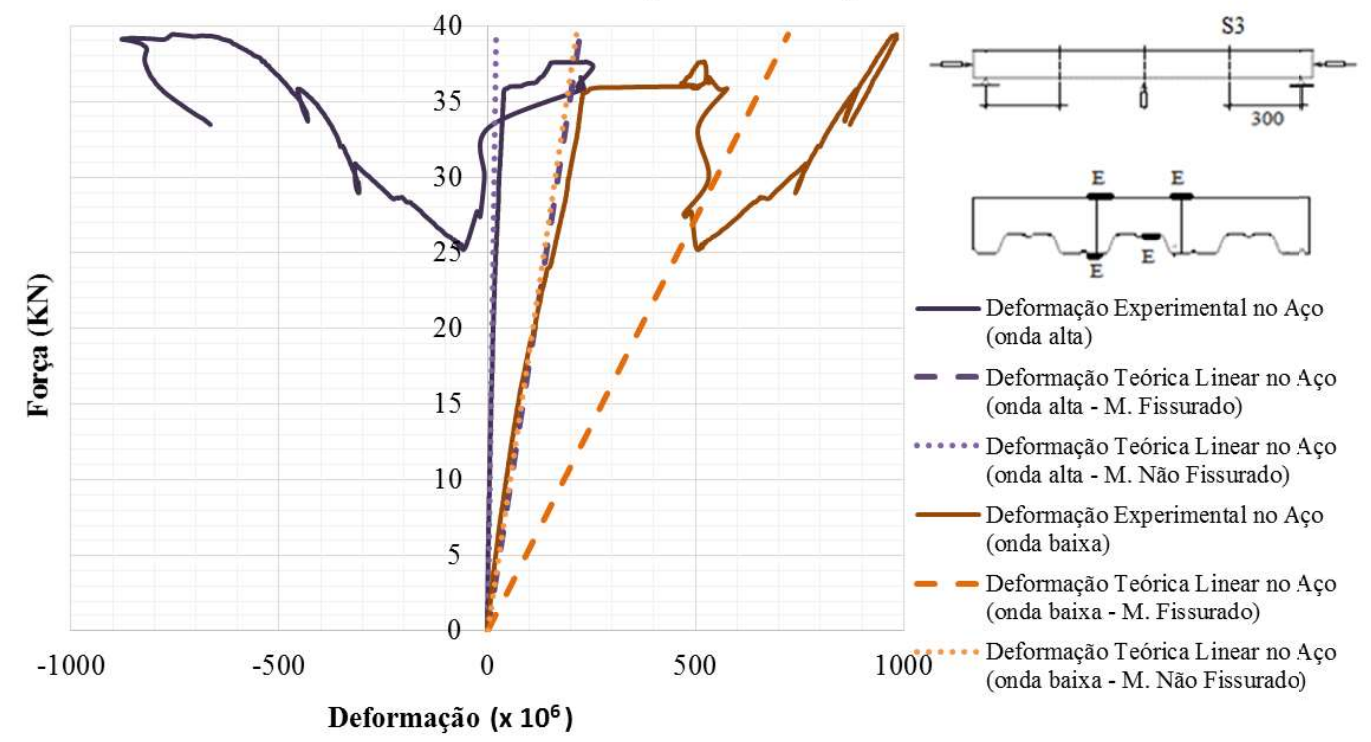

Fonte: Autora (2020) 
Figura 5. 10. Curvas Força x Deformação no concreto na seção S1 do protótipo MD55-L1.

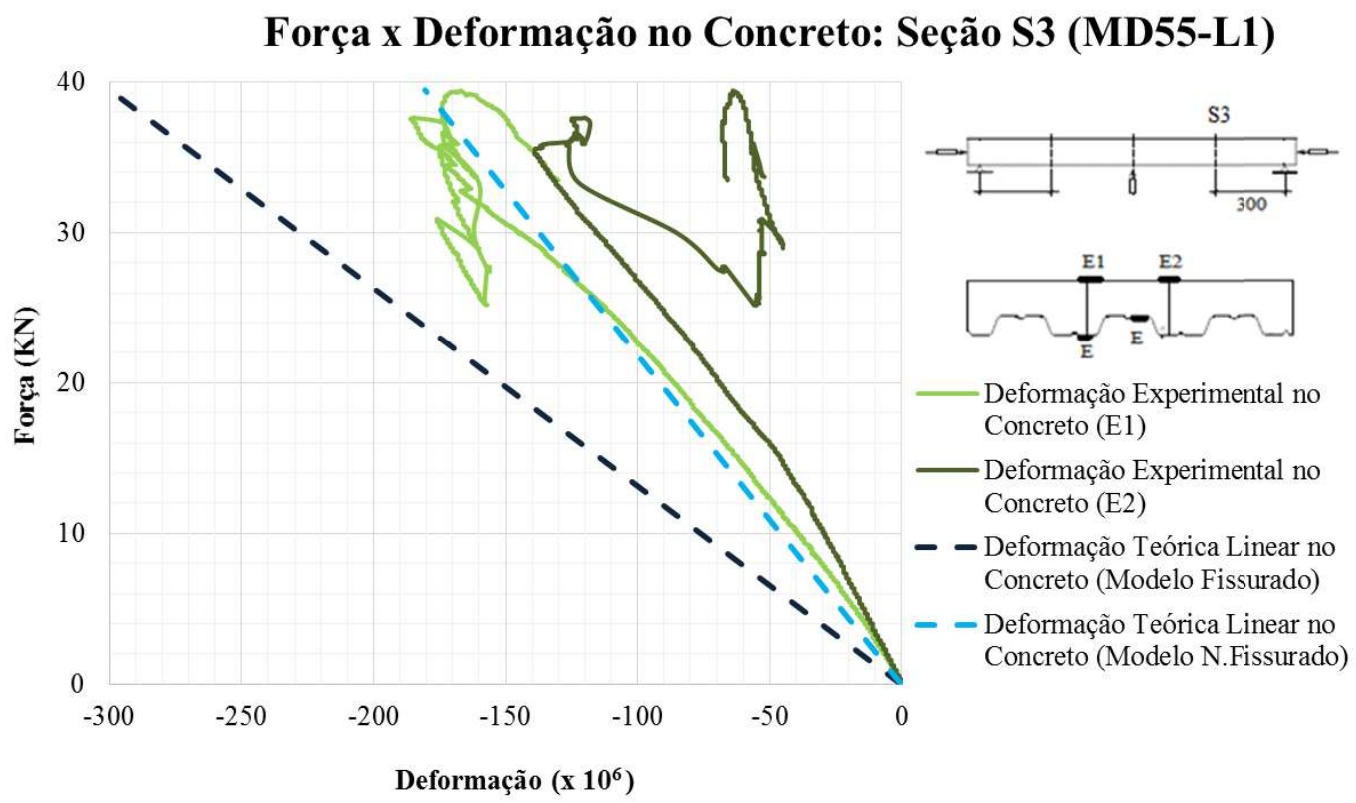

Fonte: Autora (2020)

Figura 5. 11. Curvas Força x Deformação na fôrma de aço na seção S1 do protótipo MD55-L5.

\section{Força x Deformação na Fôrma de Aço: Seção S1}

\section{(MD55-L5)}

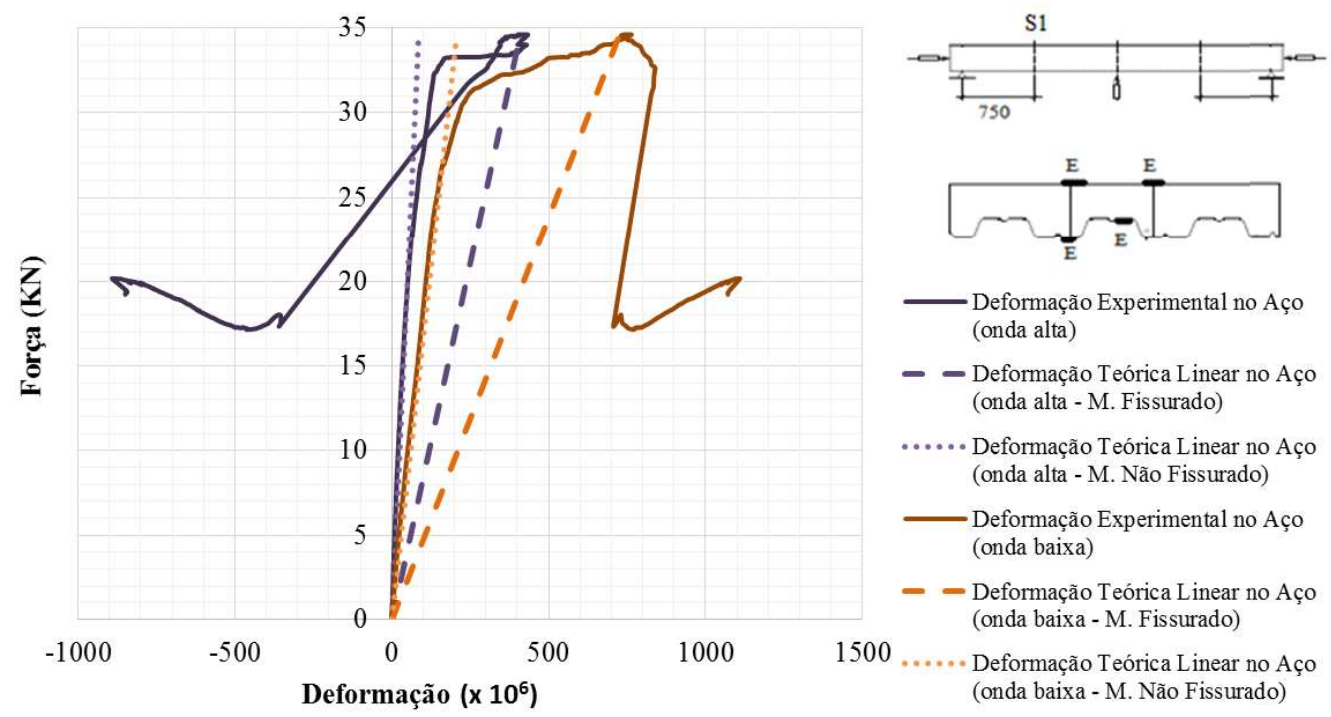

Fonte: Autora (2020) 
Figura 5. 12. Curvas Força x Deformação no concreto na seção S1 do protótipo MD55-L5.

\section{Força x Deformação no Concreto: Seção S1 \\ MD55-L5}
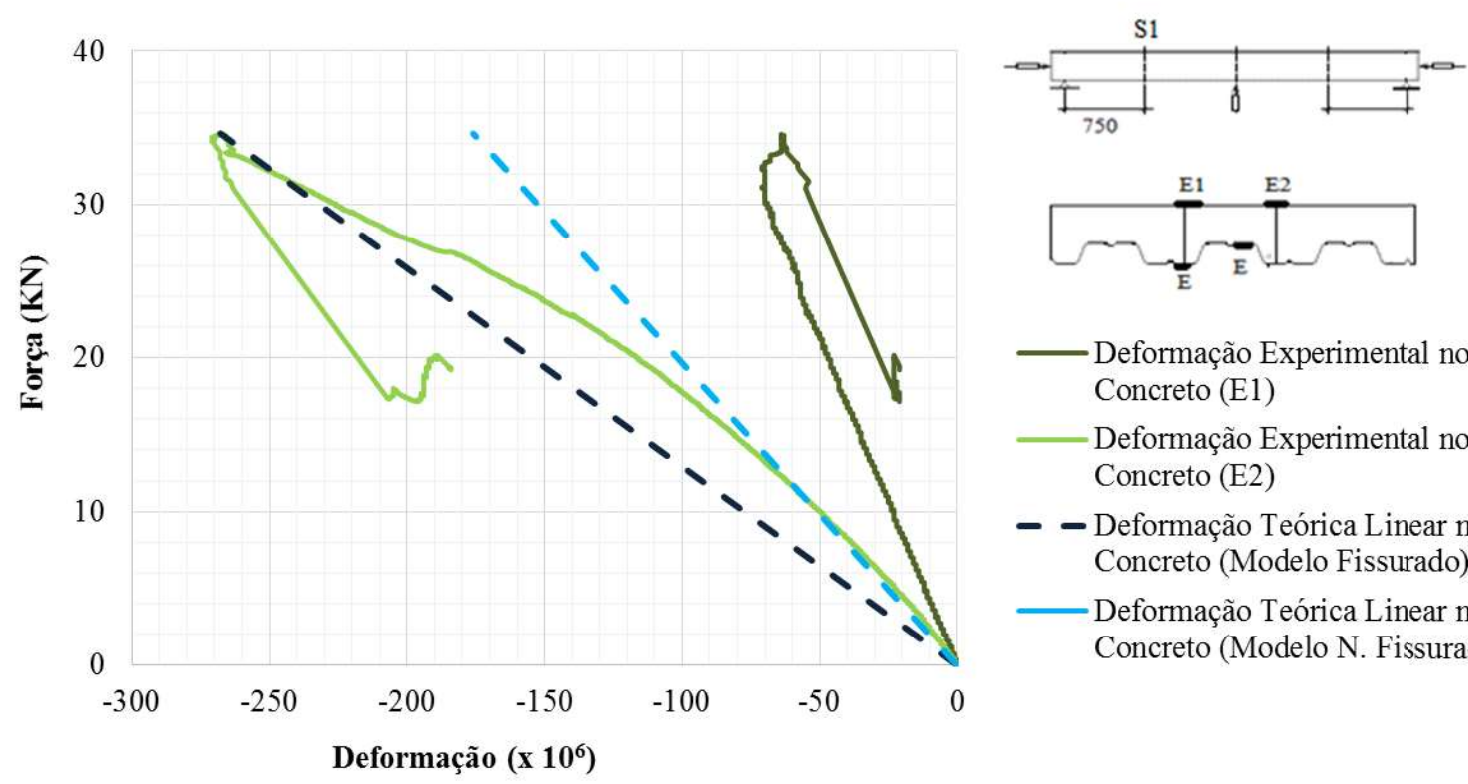

- Deformação Experimental no Concreto (E1)

- Deformação Experimental no Concreto (E2)

- - Deformação Teórica Linear no Concreto (Modelo Fissurado)

- Deformação Teórica Linear no Concreto (Modelo N. Fissurado)

Fonte: Autora (2020)

Pode-se observar que a fôrma de aço resultou completamente tracionada antes do aparecimento da fissura inicial. Isso indica a existência de uma linha neutra única na seção passando pela laje de concreto e a interação entre a fôrma de aço e o concreto é total. Ao atingir a força capaz de gerar o deslizamento relativo, a interação passa a ser parcial e observa-se que a deformação na onda alta tende a se tornar negativa, e, portanto, comprimida, indicando a existência de duas linhas neutras na seção mista.

A deformação teórica correspondente ao início do escoamento foi calculada por meio da equação 5.2.

$$
\sigma_{e}=E_{a} \varepsilon_{e}
$$

O escoamento total da fôrma de aço não foi observado em nenhum dos protótipos instrumentados sem conectores de cisalhamento. 


\subsection{LAJES MISTAS COM CONECTORES DE CISALHAMENTO}

Os resultados dos ensaios dos protótipos com conectores de cisalhamento encontram-se na Tabela 5.4.

Tabela 5. 4. Resultados experimentais dos protótipos com conectores de cisalhamento.

\begin{tabular}{l|c|c|c|c|c|c}
\hline Protótipo & $\begin{array}{c}\mathbf{F}_{\text {des }}{ }^{\mathbf{a}} \\
(\mathbf{k N})\end{array}$ & $\begin{array}{c}\mathbf{F}_{\max }{ }^{\mathbf{b}} \\
\mathbf{( k N )}\end{array}$ & $\begin{array}{c}\mathbf{F}_{\text {total }}{ }^{\mathbf{c}} \\
\mathbf{( k N )}\end{array}$ & $\mathbf{F}_{\max } / \mathbf{F}_{\text {des }}{ }^{\mathbf{d}}$ & Comportamento & $\begin{array}{c}\mathbf{V}_{\mathbf{t}}{ }^{\mathbf{~}} \\
(\mathbf{k N})\end{array}$ \\
\hline MD55-LC1 & 46,1 & 67,7 & 73,9 & 1,47 & dúctil & $\mathbf{3 7 , 0}$ \\
\hline MD55-LC2 & 32,8 & 45,1 & 60,7 & 1,38 & dúctil & $\mathbf{3 0 , 4}$ \\
\hline
\end{tabular}

${ }^{a} F_{\text {des }}$ é a força associada ao início de deslizamento relativo entre a fôrma de aço e o concreto nas extremidades. Segundo o EUROCODE 4 (2004), corresponde ao deslizamento relativo de $0,1 \mathrm{~mm}$;

${ }^{\mathrm{b}} \mathrm{F}_{\max }$ é a máxima força aplicada (peak load);

${ }^{\mathrm{c}} \mathrm{F}_{\text {total }}$ é a máxima força aplicada acrescida do peso próprio do protótipo $\left(\mathrm{P}_{\text {prot }}\right)$ e dos dispositivos de distribuição de força $\left(\mathrm{P}_{\text {disp }}\right)$;

Protótipos com $\mathrm{L}_{\mathrm{t}}=2.000$

$\mathrm{mm}: \mathrm{P}_{\text {prot }}+\mathrm{P}_{\mathrm{disp}}=4,8+1,4=6,2 \mathrm{kN}$

Protótipos com $\mathrm{L}_{\mathrm{t}}=3.800 \mathrm{~mm}: \mathrm{P}_{\text {prot }}+\mathrm{P}_{\mathrm{disp}}=13,4+2,2=15,6 \mathrm{kN}$

${ }^{\mathrm{d}} \mathrm{O}$ comportamento é considerado dúctil se $\mathrm{F}_{\max } / \mathrm{F}_{\text {des }}>1,1$;

${ }^{\mathrm{e}} \mathrm{V}_{\mathrm{t}}$ é o valor experimental representativo da força cortante, igual a $0,5 \mathrm{~F}_{\text {total }}$ se o comportamento for dúctil ou igual a $0,8\left(0,5 \mathrm{~F}_{\text {total }}\right)$ se o comportamento for frágil. 


\subsection{INFLUENCIA DOS CONECTORES DE CISALHAMENTO NO COMPORTAMENTO} DAS LAJES MISTAS

A comparação entre o comportamento dos protótipos sem e com conectores de cisalhamento, com as mesmas dimensões, serão feitas por meio das curvas força $\mathrm{x}$ flecha, força $\mathrm{x}$ deslizamento relativo e força $\mathrm{x}$ deformação no aço. As curvas referentes a todos os protótipos ensaiados encontram-se no apêndice B deste trabalho.

\section{$\underline{\text { Força x Deslizamento Relativo de Extremidade }}$}

Os gráficos das Figuras 5.13 e 5.14 apresentam as curvas força x deslizamento relativo dos protótipos MD55-L2 e MD55-LC1 (menor vão de cisalhamento) e MD55-L5 e MD55-LC2 (maior vão de cisalhamento), respectivamente, para as comparações feitas a seguir.

Figura 5. 13. Curvas força x deslizamento relativo dos protótipos MD55-L2 e MD55-LC1 (menor vão de cisalhamento).

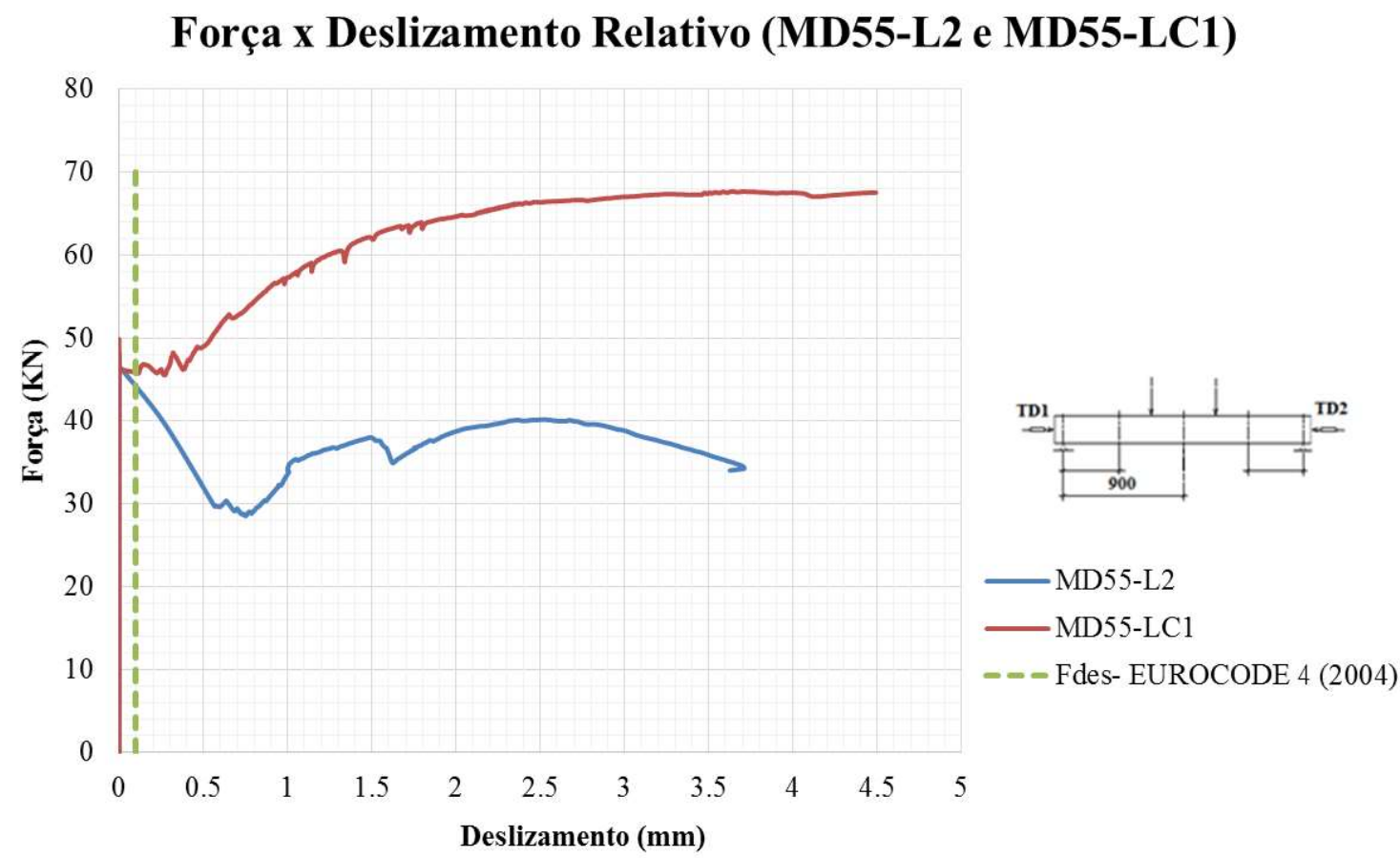

Fonte: Autora (2020) 
Figura 5. 14. Curvas força $\mathrm{x}$ deslizamento relativo dos protótipos MD55-L5 e MD55-LC2 (maior vão de cisalhamento).

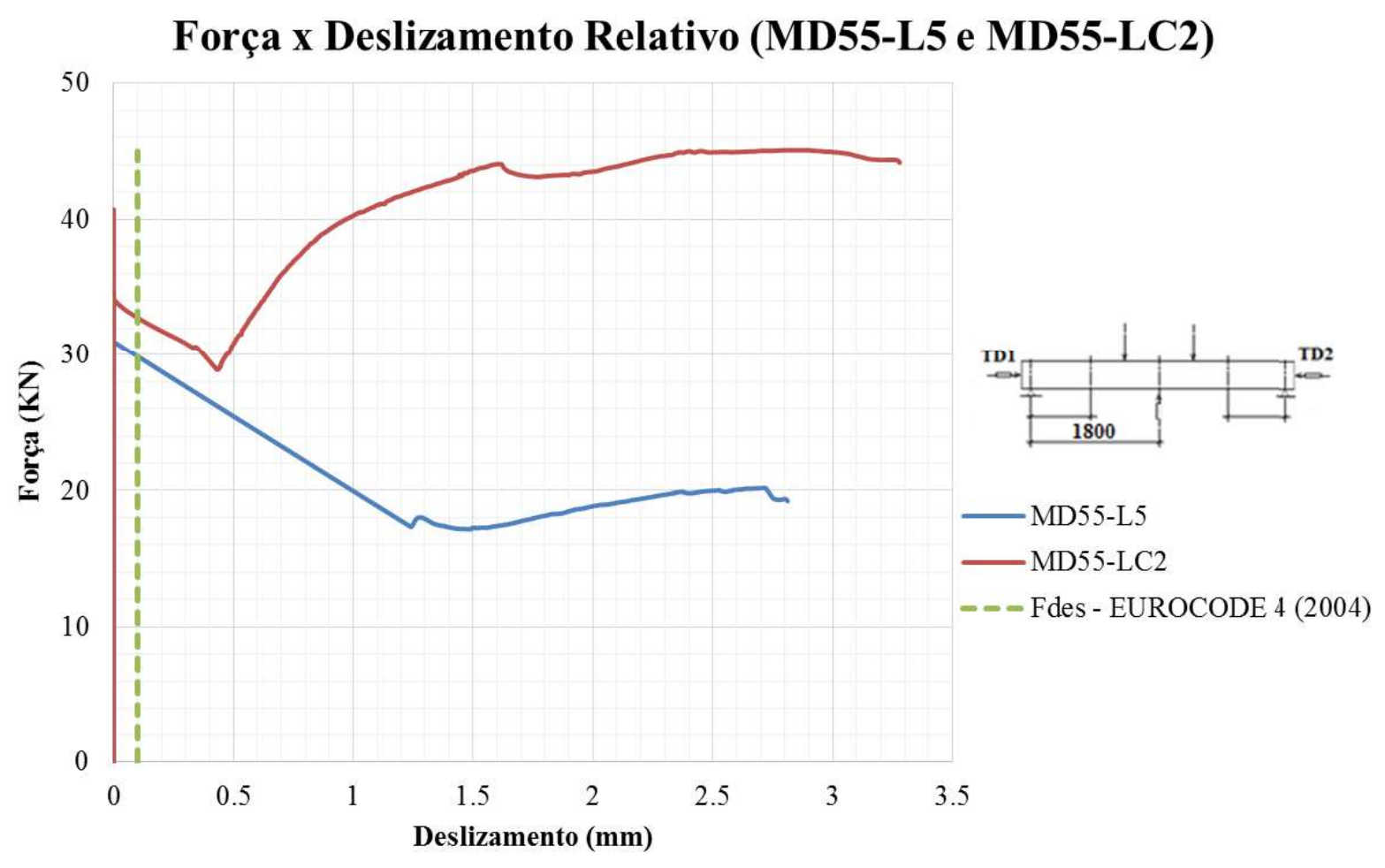

Fonte: Autora (2020)

A partir das curvas dos gráficos das Figuras 5.13 e 5.14 pode-se observar que a força que causa o deslizamento de extremidade dos protótipos com e sem conectores de cisalhamento são próximas. Isso se deve ao fato de que a força necessária para romper a aderência química na interface aço-concreto não é influenciada pela existência da ancoragem de extremidade.

Os protótipos com conectores de cisalhamento apresentam maior restrição ao deslizamento horizontal em relação aos protótipos sem ancoragem de extremidade, após a força de deslizamento ser atingida, uma vez que além da ligação mecânica entre as mossas da fôrma de aço e o concreto e o atrito nos apoios, os conectores de cisalhamento também passam a ser responsáveis pela resistência ao deslizamento relativo, provocando um aumento de força última.

\section{Força x Flecha}

Os gráficos das Figuras 5.15 e 5.16 mostram as curvas força $\mathrm{x}$ flecha para os protótipos MD55-L2 e MD55-LC1 e MD55-L5 e MD55-LC2, respectivamente. 
Figura 5. 15. Curvas força x flecha dos protótipos MD55-L2 e MD55-LC1.

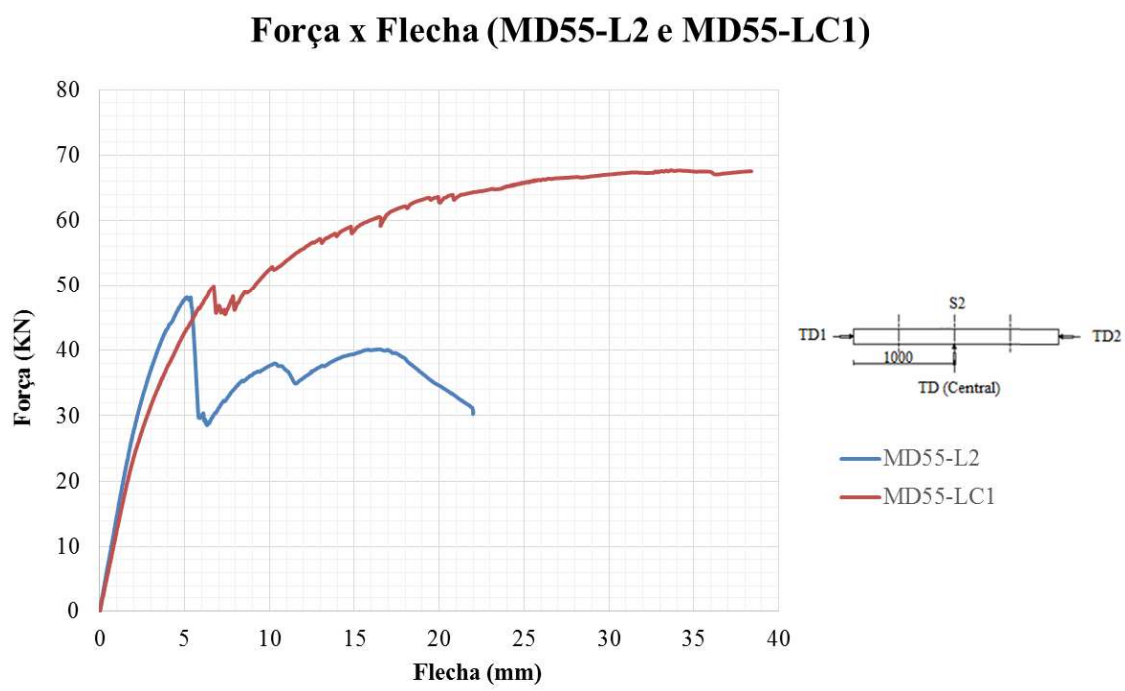

Fonte: Autora (2020)

Figura 5. 16. Curvas força $x$ flecha dos protótipos MD55-L5 e MD55-LC2.

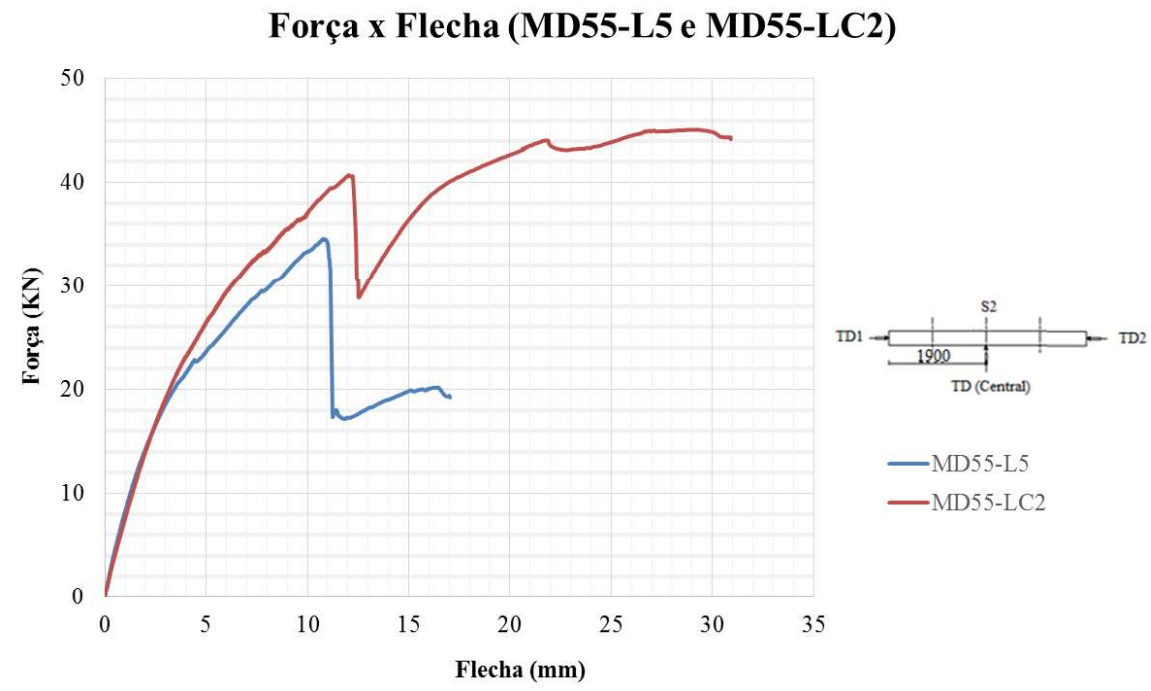

Fonte: Autora (2020)

De acordo com as figuras, pode-se observar uma redução brusca na rigidez dos protótipos sem conectores de cisalhamento. Para os protótipos com conectores de cisalhamento, as curvas mostram um comportamento contínuo do protótipo MD55-LC1 e uma queda de força 
consideravelmente menor para o protótipo MD55-LC2 quando comparado ao protótipo com as mesmas dimensões e sem ancoragem de extremidade (MD55-L5).

Ao contrário dos protótipos sem ancoragem de extremidade que apresentaram um comportamento frágil, para os protótipos com conectores de cisalhamento, a força última excedeu à força que levou a um deslizamento relativo de $0,1 \mathrm{~mm}$ em mais de $10 \%$, caracterizando um comportamento dúctil, como mostram os valores da Tabela 5.4. Esse aumento no nível de força aplicada além do estágio da fissura inicial também pode ser observado nas curvas das figuras 5.15 e 5.16 .

\section{Força x Deformação no Aço}

Os gráficos das Figuras 5.17 e 5.18 apresentam as curvas força x deformação no aço dos protótipos com as mesmas dimensões com e sem conectores de cisalhamento.

Figura 5. 17. Curvas força x deformação na fôrma de aço dos protótipos MD55-L1 e MD55-LC1.

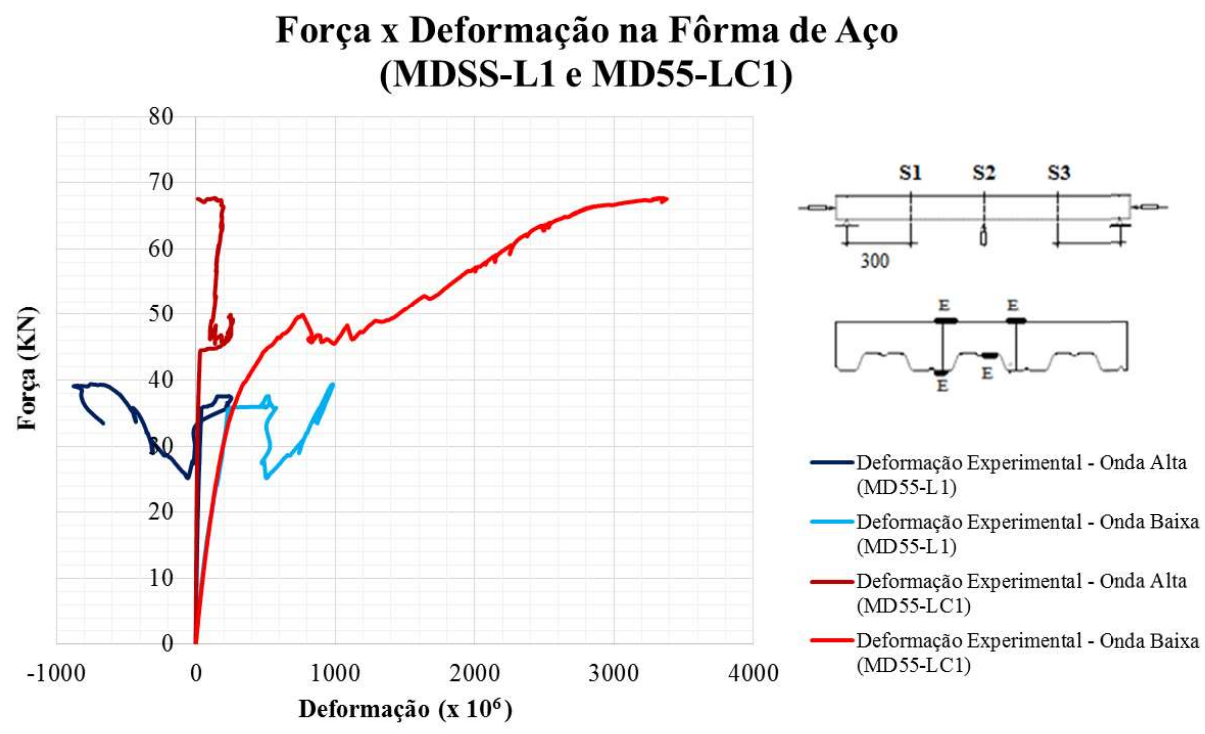

Fonte: Autora (2020) 
Figura 5. 18. Curvas força x deformação na fôrma de aço dos protótipos MD55-L5 e MD55-LC2.

\section{Força x Deformação no Aço (MD55-L5 e MD55-LC2)}

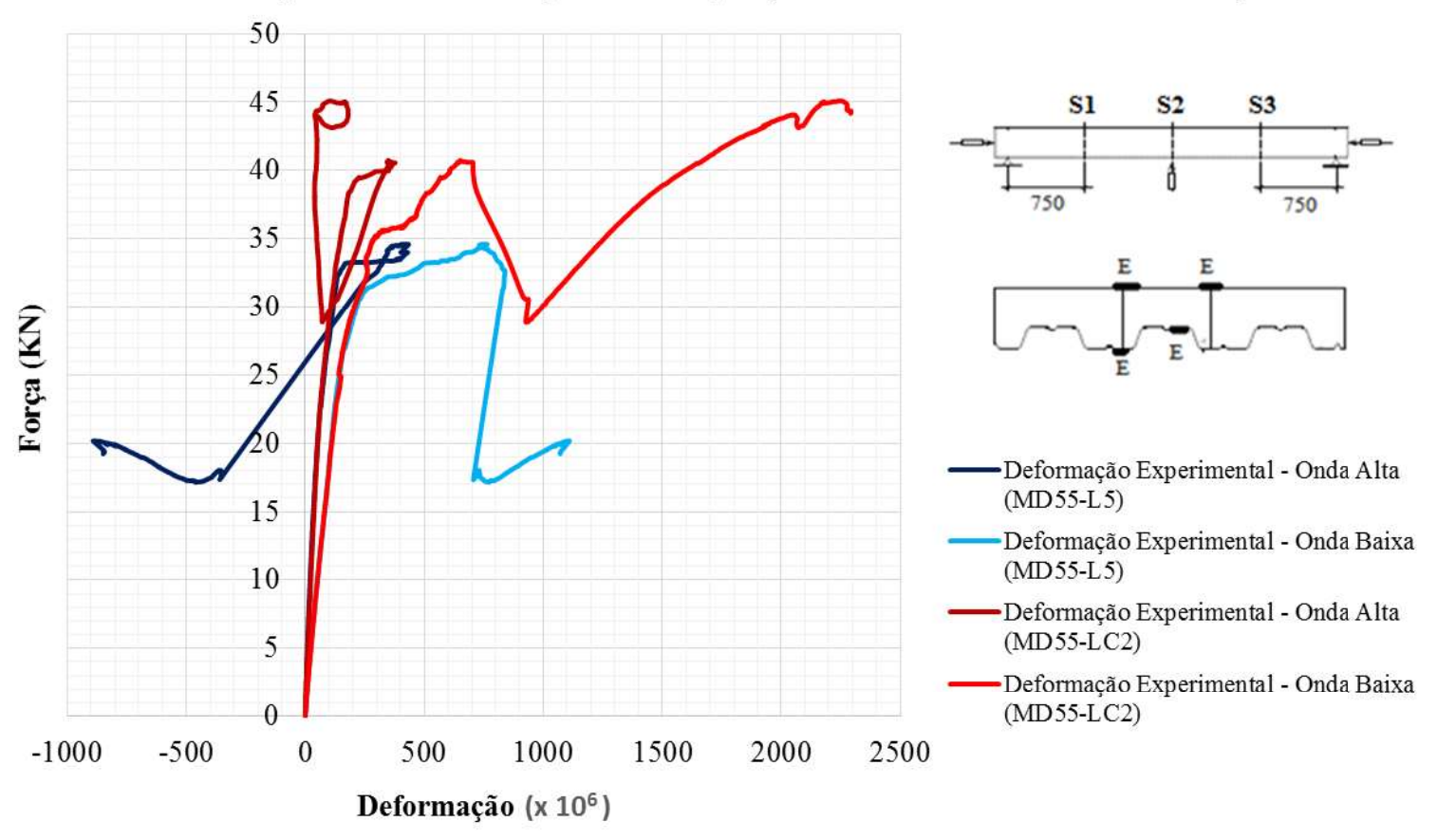

Fonte: Autora (2020)

De acordo com as curvas apresentadas, pode-se observar que a presença dos conectores de cisalhamento aumentou a interação entre a fôrma de aço e o concreto, uma vez que enquanto a onda alta dos protótipos ancorados na extremidade se manteve tracionada, os protótipos sem conectores apresentaram duas linhas neutras na seção identificadas pela compressão da onda alta que no estágio inicial encontrava-se tracionada, caracterizando a interação parcial entre os materiais.

Além disso, observa-se que a onda baixa dos protótipos com conectores de cisalhamento atingiu maiores níveis de deformação quando comparados aos protótipos não ancorados, chegando a alcançar o limite de escoamento.

Apresendados os resultados dos ensaios e discutido o comportamento estrutural das lajes mistas com e sem conectores de cisalhamento, determina-se, no capítulo a seguir, a resistência ao cisalhamento longitudinal das lajes mistas por meio do método $m-k$ e da interação parcial para os protótipos sem e com conectores, respectivamente. 


\section{CÁLCULO DA RESISTÊNCIA AO CISALHAMENTO LONGITUDIAL}

Conforme mencionado anteriormente, a ABNT NBR 8800 (2008) apresenta dois métodos para a determinação da resistência ao cisalhamento longitudinal das lajes mistas: o método $m-k$ e o método da interação parcial. O EUROCODE 4 (2004), o CSSBIS2-2008 (2008) e o ANSI/ASCE 3-91 (1992) são citados pela norma brasileira para a aplicação do método $m$ - $k$ e o EUROCODE 4 (2004) para a aplicação do método da interação parcial.

Neste capítulo, o cálculo da resistência ao cisalhamento longitudinal dos protótipos sem ancoragem de extremidade foi feito por meio da aplicação do método m-k e para os protótipos com conectores de cisalhamento, o método da interação parcial, ambos seguindo as prescrições do EUROCODE 4 (2004). O método da interação parcial pode ser aplicado apenas em lajes dúcties e de acordo com QUEIROZ et. al. (2001) ele permite que se incluam na análise armaduras adicionais para auxiliar na resistência ao momento positivo, bem como tirar proveito da presença de conectores de cisalhamento nas extremidades dos vãos da fôrma utilizados pelas vigas mistas.

\subsection{APLICAÇÃO DO MÉTODO $M-K$}

Neste tópico, será apresentado o procedimento de determinação das constantes $m$ e $k$ para as lajes mistas ensaiadas, por meio da Tabela 6.1, seguindo as recomendações do Eurocode 4 (2004).

Tabela 6. 1. Cálculo e análise estatística das constantes empíricas m e k (Unidades: $\mathrm{N}$ e mm).

(continua)

\begin{tabular}{|c|c|c|c|c|}
\hline Protótipo & $V_{t}(N)$ & $\frac{A_{F, e f L}}{b_{L} L_{s}}\left(x 10^{3}\right)$ & $\begin{array}{c}\frac{V_{t}}{b_{L} d_{F}} \\
\left(\mathbf{N} / \mathbf{m m}^{2}\right)\end{array}$ & Análise estatística de $\frac{V_{t}}{b_{L} d_{F}}$ \\
\hline MD55-L1 ${ }^{\mathrm{b}}$ & 17.880 & 2,17 & 0,278 & \multirow{4}{*}{$\begin{array}{l}\text { Média: } \mathrm{v}_{\mathrm{m}}=0,286 \mathrm{~N} / \mathrm{mm}^{2} \\
\text { Desvio-padrão: } \mathrm{s}=0,0094 \mathrm{~N} / \mathrm{mm}^{2} \\
\text { a Valor característico: } \mathrm{v}_{\mathrm{k}}=0,270 \mathrm{~N} / \mathrm{mm}^{2}\end{array}$} \\
\hline MD55-L2 & 21.400 & 2,17 & 0,278 & \\
\hline MD55-L3 & 22.640 & 2,17 & 0,294 & \\
\hline MD55-L4 & 22.720 & 2,17 & 0,295 & \\
\hline MD55-L5 & 19.720 & 1,08 & 0,148 & \multirow{3}{*}{$\begin{array}{l}\text { Média: } \mathrm{v}_{\mathrm{m}}=0,153 \mathrm{~N} / \mathrm{mm}^{2} \\
\text { Desvio-padrão: } \mathrm{s}=0,0047 \mathrm{~N} / \mathrm{mm}^{2} \\
{ }^{a} \text { Valor característico: } \mathrm{v}_{\mathrm{k}}=0,145 \mathrm{~N} / \mathrm{mm}^{2}\end{array}$} \\
\hline MD55-L6 & 20.440 & 1,08 & 0,153 & \\
\hline MD55-L7 & - & - & - & \\
\hline
\end{tabular}




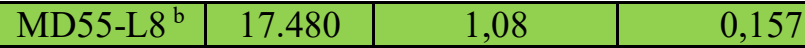

$\mathrm{t}_{\mathrm{n}}=0,80 \mathrm{~mm}$

$\mathrm{A}_{\mathrm{F}, \mathrm{efL}}=912 \mathrm{~mm}^{2}$

$\mathrm{d}_{\mathrm{F}}=82,5 \mathrm{~mm}$ de L1 a L4

$\mathrm{d}_{\mathrm{F}}=142,5 \mathrm{~mm}$ de L5 a L8

${ }^{a}$ Valor característico inferior correspondente ao quantil de 5\% (distribuição normal): $v_{k}=v_{m}-1,65 \mathrm{~s}$

${ }^{b}$ Devido ao descolamento lateral de parte da fôrma foi admitido $A_{F, e f}=760 \mathrm{~mm}^{2}$ e b $=779,2 \mathrm{~mm}$ (redução de 1 semionda)

-Cálculo de $m$ e $k$ para valores médios:

$V_{l, R m}=b_{L} d_{F}\left[\left(\frac{m A_{F, e f L}}{b_{L} L_{s}}\right)+k\right]$

$m=122 \mathrm{~N} / \mathrm{mm}^{2}$

$k=0,021 \mathrm{~N} / \mathrm{mm}^{2}$

-Cálculo de $m$ e $k$ para valores característicos:

$m=114,68 \mathrm{~N} / \mathrm{mm}^{2}$

$k=0,021 \mathrm{~N} / \mathrm{mm}^{2}$

- Cálculo da força cortante para valores de projeto:

$V_{l, R d}=\frac{b_{L} d_{F}}{\gamma_{s l}}\left[\left(\frac{114,68 A_{F, e f L}}{b_{L} L_{s}}\right)+0,021\right]$

$\gamma_{s l}=1,25$

Fonte: Autora (2020)

A reta correspondente a expressão da força cortante determinada por meio do método $m$ $k$, com base em valores de projeto, é representada no gráfico da Figura 6.1. 
Figura 6. 1. Reta m-k determinada com base em valores de projeto.

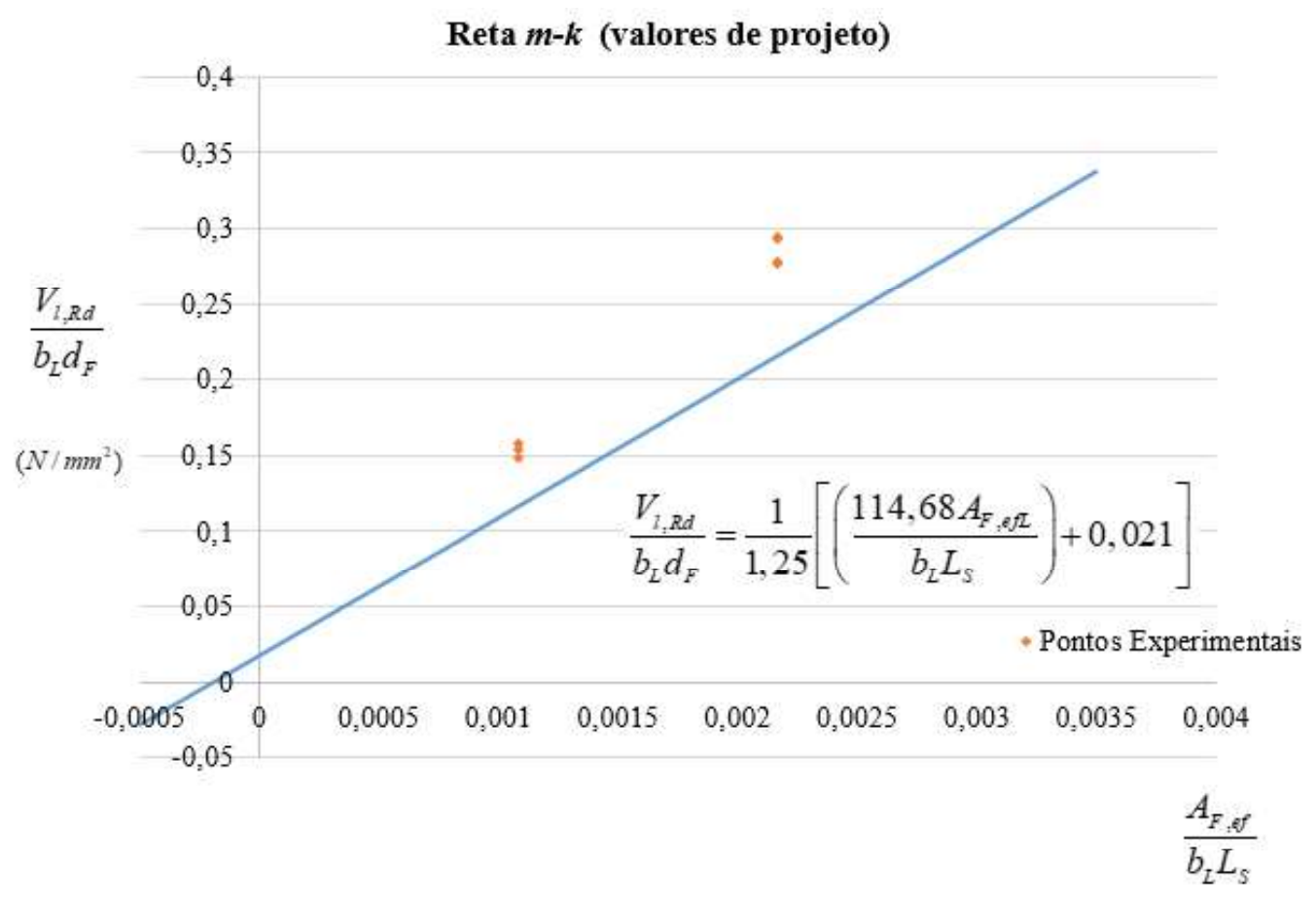

Fonte: Autora (2020)

A Tabela 6.2 apresenta a comparação entre os valores experimentais da força cortante $\left(V_{t}\right)$ e os valores médios teóricos calculados pela aplicação do método $m-k$.

Tabela 6. 2. . Análise comparativa entre as forças cortantes experimentais (Vt) e as obtidas pelo método $m-k\left(V_{l, R m}\right)$ com base em valores médios.

\begin{tabular}{|c|c|c|c|c|}
\hline Protótipo & $\begin{array}{c}\text { Experimental } \\
\mathrm{V}_{\mathrm{t}}(\mathrm{kN})\end{array}$ & $\begin{array}{c}\text { Teórico } \\
\text { Médio } \\
\text { (método } \boldsymbol{m} \text {-k) } \\
V_{\ell, R m}(\mathrm{kN})\end{array}$ & $\begin{array}{c}\text { Teórico de } \\
\text { Projeto } \\
\text { (método } \boldsymbol{m} \text {-k) } \\
V_{\ell, R d}(\mathrm{kN})\end{array}$ & $\begin{array}{c}\text { Experimental / } \\
\text { Teórico }\end{array}$ \\
\hline MD55-L1 & 17,88 & 18,35 & 13,86 & 0,974 \\
\hline MD55-L2 & 21,40 & 22 & 16,63 & 0,973 \\
\hline MD55-L3 & 22,64 & 22 & 16,63 & 1,03 \\
\hline MD55-L4 & 22,72 & 22 & 16,63 & 1,03 \\
\hline MD55-L5 & 19,72 & 20,4 & 15,49 & 0,967 \\
\hline MD55-L6 & 20,44 & 20,4 & 15,49 & 1,00 \\
\hline MD55-L7 $^{a}$ & - & & - & - \\
\hline MD55-L8 & 17,48 & 17 & 12,9 & 1,03 \\
\hline
\end{tabular}

Fonte: Autora (2020) 


\subsection{MOMENTO FLETOR RESISTENTE CORRESPONDENTE À INTERAÇÃO COMPLETA}

A Tabela 6.3 apresenta a relação entre o máximo momento fletor solicitante $\left(\mathrm{M}_{\exp }\right)$ e o momento fletor resistente admitindo interação completa $\left(\mathrm{M}_{\mathrm{pRm}}\right)$. Para efeito de comparação com os resultados experimentais, o momento fletor resistente foi determinado desconsiderando-se os coeficientes de ponderação da resistência, bem como o fator de modificação da resistência à compressão do concreto $(0,85)$.

Tabela 6. 3. Momento fletor solicitante experimental versus momento fletor resistente.

\begin{tabular}{|c|c|c|c|}
\hline Protótipo & $\mathbf{M}_{\exp }(\mathrm{kN} . \mathrm{cm})^{a}$ & $\mathrm{M}_{\mathrm{pRm}}(\mathrm{kN} . \mathrm{cm})^{\mathrm{b}}$ & $\mathbf{M}_{\exp } / \mathbf{M}_{\mathrm{pRm}}$ \\
\hline MD55-L1 & 1.006 & 1.953 & 0,52 \\
\hline MD55-L2 & 1.204 & \multirow{3}{*}{2.343} & 0,51 \\
\hline MD55-L3 & 1.274 & & 0,54 \\
\hline MD55-L4 & 1.278 & & 0,55 \\
\hline MD55-L5 & 2.219 & \multirow{3}{*}{4.144} & 0,54 \\
\hline MD55-L6 & 2.300 & & 0,55 \\
\hline MD55-L7 & - & & - \\
\hline MD55-L8 & 1.967 & 3.453 & 0,57 \\
\hline \multicolumn{4}{|c|}{${ }^{\mathrm{a}} \mathrm{M}_{\text {exp }}$ é o máximo valor do momento fletor solicitante, dado por $0,5 \mathrm{~F}_{\text {total }} \mathrm{L}_{\mathrm{s}}$} \\
\hline
\end{tabular}

Fonte: Autora (2020)

\subsection{APLICAÇÃO DO MÉTODO DA INTERAÇÃO PARCIAL}

Para cada protótipo ensaiado será determinada a tensão de cisalhamento média na interface entre o aço e o concreto. O processo de cálculo do método da interação parcial aplicado neste tópico foi descrito anteriormente no item 4.2.2.2.

Inicialmente serão determinadas as seguintes propriedades geométricas da fôrma de aço Steel Deck Modular MD55: área efetiva $\left(A_{F, e f_{n}}\right)$, altura do centro geométrico $\left(e_{n}\right)$, altura do eixo de igual área $\left(e_{p_{n}}\right)$. O subíndice $\mathrm{n}$ indica que as propriedades foram calculadas para uma única nervura. Para o cálculo das propriedades geométricas, o perfil foi linearizado mantendo o valor da área efetiva da fôrma $\left(A_{F, \text { efL }}\right)$ de $912 \mathrm{~mm}^{2}$. As Figuras 6.2 e 6.3 apresentam, respectivamente, as 
dimensões do perfil do MD55 para uma única nervura e para o perfil completo com três nervuras iguais.

Figura 6. 2. Dimensões, em mm, linearizadas de uma nervura do MD55.

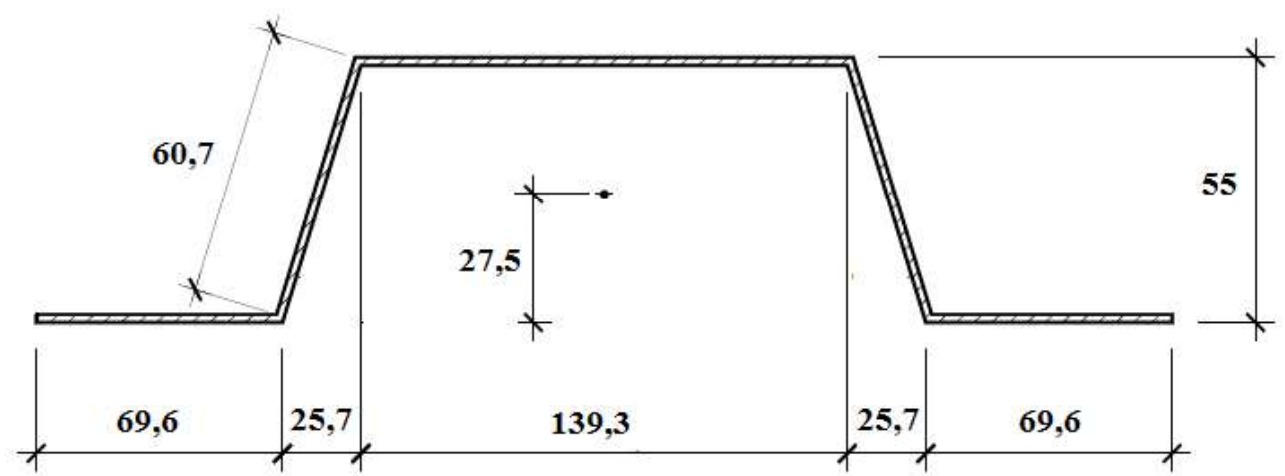

Fonte: Autora (2020)

Figura 6. 3. Perfil completo do MD55 linearizado com dimensões em mm.

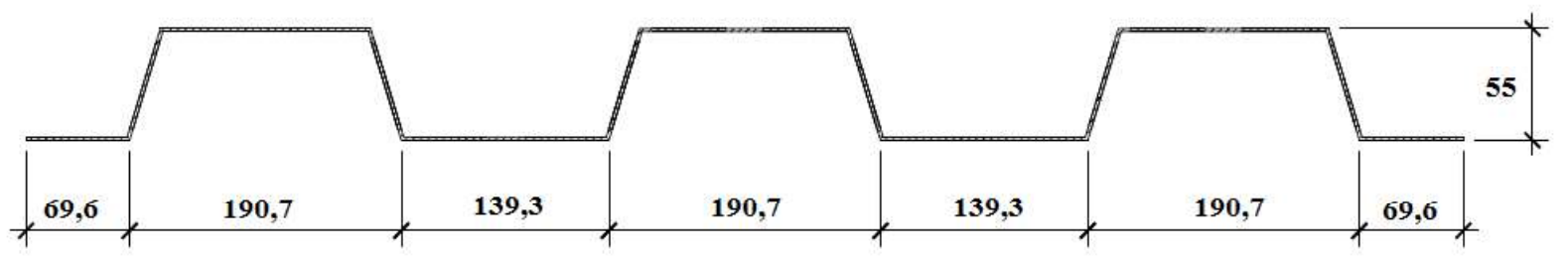

Fonte: Autora (2020)

As propriedades geométricas da fôrma foram calculadas de acordo com as dimensões apresentadas nas Figuras 6.2 e 6.3 , sendo $A_{F, e f_{n}}=304 \mathrm{~mm}^{2}, e_{n}=e_{p_{n}}=27,5 \mathrm{~mm}$. Além das propriedades geométricas já determinadas, o método da interação parcial requer os valores das seguintes propriedades mecânicas da fôrma: momento de plastificação $\left(M_{p a_{L}}\right)$ e a força normal no aço $\left(N_{p a_{L}}\right)$, calculadas a partir das equações 6.1 e 6.2

$$
N_{p a_{L}}=A_{F, e f_{L}} f_{y F}=912 \times 329=300 \mathrm{KN}
$$




$$
M_{p a_{L}}=T_{p a}\left(2 y_{c g_{p a}}\right)
$$

O $y_{c g_{p a}}$ é a altura do centro geomético da parte da fôrma acima ou abaixo da linha de igual área em relação a essa mesma linha, sendo seguinte o valor obtido: $y_{c g_{p a}}=23,3 \mathrm{~mm}$. $T_{p a}$ refere-se a resultante das tensões de plastificação de tração na parte da fôrma abaixo da linha de igual área dada pela equação 6.3 .

$$
T_{p a}=\frac{N_{p a_{L}}}{2}=150 \mathrm{KN}
$$

A Tabela 6.4 apresenta os valores de $N_{p a_{L}}$ e $M_{p a_{L}}$.

Tabela 6. 4. Valores das $N_{p a_{L}}$ e $M_{p a_{L}}$ do perfil MD55.

\begin{tabular}{c|c}
\hline$N_{p a_{L}}(\mathbf{k N})$ & $M_{p a_{L}}(\mathbf{k N . c m})$ \\
\hline 300 & 699 \\
\hline
\end{tabular}

Fonte: Autora (2020)

Antes de apresentar o equacionamento do método da interação parcial, é necessária a determinação da força normal no concreto para interação completa $\left(N_{c f}\right)$ e do momento fletor correspondente à falha por cisalhamento longitudinal na seção de aplicação da força $\left(M_{\text {exp }}\right)$, calculados respectivamente, pelas equações 6.4 e 6.5 .

$$
\begin{aligned}
& N_{c f}=0,85 f_{c d} a b=N_{p a} \\
& M_{\text {exp }}=0,5 F_{\text {total }} L_{S}
\end{aligned}
$$

Além disso, de posse dos valores da resultante de compressão no concreto para que toda laje acima da forma esteja plastificada $\left(\bar{N}_{c}\right)$, determinada pela equação 6.6 , e de $N_{p a_{L}}$, pode-se determinar se a linha neutra plástica encontra-se acima ou abaixo da face superior da fôrma de aço. 


$$
\bar{N}_{c}=f_{c d} b t_{c}
$$

Os valores de $\bar{N}_{c}$ encontrados para os protótipos MD55-LC1 e MD55-LC2 foram, respectivamente, iguais a $1961,7 \mathrm{KN}$ e $3915 \mathrm{KN}$. Como $\bar{N}_{c}>N_{p a_{L}}$, para ambos os protótipos, então a linha neutra plástica encontra-se acima da face superior da fôrma de aço.

A Tabela 6.5 apresenta os resultados para os protótipos MD55-LC1 e MD55-LC2. O presente procedimento de cálculo utiliza valores médios, sendo descartado, portanto, o coeficiente 0,85

Tabela 6. 5. Valores da força normal no concreto para interação completa $\left(N_{c f}\right)$ e do momento fletor correspondente à falha por cisalhamento longitudinal na seção de aplicação da força

$$
\left(M_{\text {exp }}\right) \text {. }
$$

\begin{tabular}{c|c|c}
\hline Protótipo & $\begin{array}{c}\boldsymbol{N}_{\boldsymbol{c f}} \\
(\mathbf{K N})\end{array}$ & $\begin{array}{c}M_{\exp } \\
\text { (KN.cm) }\end{array}$ \\
\hline MD55-LC1 & 300 & 1665 \\
\hline MD55-LC2 & 300 & 2736 \\
\hline \multicolumn{2}{|c}{ Fonte: Autora (2020) }
\end{tabular}

De acordo com o equacionamento descrito na seção 3.2.2.2, determina-se a força normal no concreto dada pela equação 6.7 .

$$
N_{c}=\frac{-b \pm \sqrt{b^{2}-4 a c}}{2 a} \text { com a } \neq 0 \text { e } 0 \leq N_{c} \leq N_{c f}
$$

Onde, os coeficientes a, b e c são calculados, respectivamente, pelas equações 6.8, 6.9 e 6.10 .

$$
\begin{aligned}
& a=\frac{0,5}{f_{c} b_{L}}-\frac{e_{p}-e}{N_{p a_{L}}} \\
& b=e_{p}-h_{t}+1,25 \frac{M_{p a_{L}}}{N_{p a_{L}}}
\end{aligned}
$$




$$
c=M_{\text {exp }}-1,25 M_{p a_{L}}
$$

Aplicando as equações 6.8, 6.9 e 6.10 obtemos os seguintes valores de a, b e c para a laje MD55-LC1:

$$
\begin{aligned}
& a=\frac{0,5}{3,645 \times 93,3}=1,47 \times 10^{-3} \mathrm{~cm} / \mathrm{KN} \\
& b=2,75-11,35+1,25 \times \frac{699}{300}=-5,69 \mathrm{~cm} \\
& c=1665-1,25 \times 699=791,25 \mathrm{KNcm}
\end{aligned}
$$

Aplicando a equação a equação 6.7 obtemos: $N_{c}^{\prime}=3726,3 \mathrm{KN}$ e $N_{c}^{\prime \prime}=144,5 \mathrm{KN}$

Pela condição de existência da equação $6.70 \leq N_{c} \leq 300 \mathrm{KN}$, assim:

$$
\mathrm{N}_{\mathrm{c}}=144,5 \mathrm{KN}
$$

Deve-se verificar se para o valor encontrado de $N_{c}$ é valida a condição $M_{p r} \leq M_{p a}$. Sendo $\mathrm{M}_{\mathrm{pr}}$ dado pela equação 6.14.

$$
\begin{gathered}
M_{p r}=1,25 M_{p a_{L}}\left(1-\frac{N_{c}}{N_{p a_{L}}}\right)=1,25 \times 699 x\left(1-\frac{144,5}{300}\right)=452,9 \mathrm{KNcm}< \\
M_{p a_{L}}=699 \mathrm{KNcm}(\mathrm{OK})
\end{gathered}
$$

Com o valor de $\mathrm{N}_{\mathrm{c}}$ calculado e verificadas as condições descritas, pode-se determinar o valor da tensão de cisalhamento média na interface aço-concreto $\left(\tau_{u}\right)$ por meio da equação 6.15 .

$$
\tau_{u}=\frac{N_{c}}{b_{L}\left(L_{S}+L_{0}\right)}=\frac{144.500}{933(450+100)}=0,28 \mathrm{MPa}
$$

Aplicando as equações 6.8, 6.9 e 6.10 obtemos os seguintes valores de a, b e c para a laje MD55-LC2:

$$
a=\frac{0,5}{3,645 \times 94,07}=1,46 \times 10^{-3} \mathrm{~cm} / \mathrm{KN}
$$




$$
\begin{gathered}
b=2,75-17,175+1,25 \times \frac{699}{300}=-11,51 \mathrm{~cm} \\
c=2736-1,25 \times 699=1862,25 \mathrm{KNcm}
\end{gathered}
$$

Aplicando a equação 6.7 obtém-se:

$$
N_{c}^{\prime}=7718,3 \mathrm{KN} \text { e } N_{c}^{\prime \prime}=165,3 \mathrm{KN}
$$

Pela condição de existência da equação $6.70 \leq N_{c} \leq 300 \mathrm{KN}$, assim:

$$
N_{c}=165,3 \mathrm{KN}
$$

Verificando a desigualdade $M_{p r} \leq M_{p a_{L}}$ :

$$
\begin{gathered}
M_{p r}=1,25 M_{p a}\left(1-\frac{N_{c}}{N_{p a}}\right)=1,25 \times 699 x\left(1-\frac{165,3}{300}\right)=392,3 \mathrm{KNcm}< \\
M_{p a_{L}}=699 \mathrm{KNcm}(\mathrm{OK})
\end{gathered}
$$

Por fim, pode-se calcular o valor de $\tau_{u}$ aplicamos a equação 6.20.

$$
\tau_{u}=\frac{N_{c}}{b_{L}\left(L_{S}+L_{0}\right)}=\frac{165,3 \times 1000}{940,7(900+100)}=0,176 \mathrm{MPa}
$$

A Figura 6.4 apresenta as forças que atuam em um trecho da laje, onde a força de compressão $\mathrm{N}_{\mathrm{c}}$ é dada pela equação 6.21. sendo $\mathrm{L}_{\mathrm{x}}=\mathrm{L}_{\mathrm{s}}$ 
Figura 6. 4. Representação das forças que atuam em um trecho de comprimento $L_{x}$ a partir do apoio da laje mista.

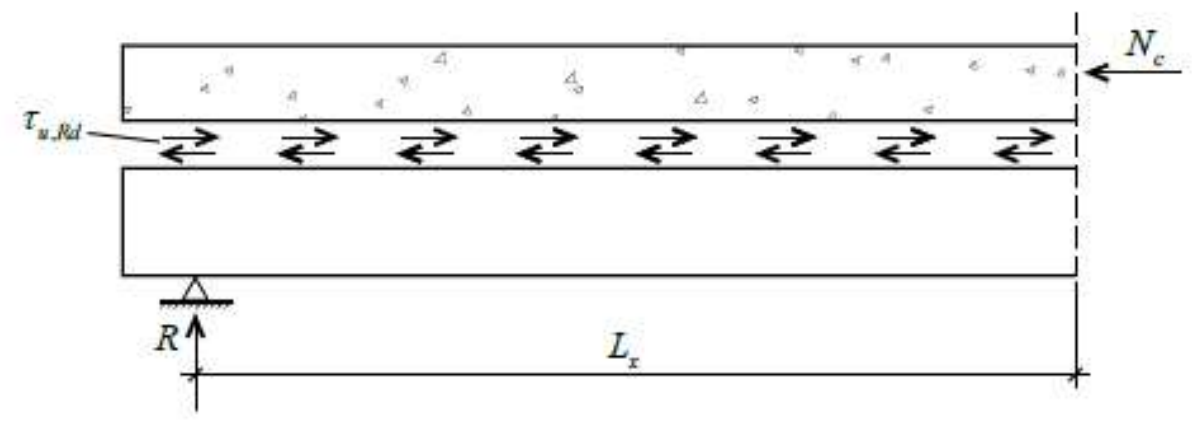

Fonte: Grossi (2016)

De acordo com a Figura 6.4, pelo equilíbrio de forças obtem-se a equação 6.21.

$$
N_{c}=\tau_{u} b_{L} L_{x} \leq N_{c f}
$$

Utilizando o valor médio da tensão cisalhante calculado para os protótipos MD55-LC1 e MD55-LC2 $\left(\tau_{u, m}=0,228 \mathrm{MPa}\right)$ e plicando a equação 6.21 obtem-se os seguintes resultados:

\section{$\underline{\text { MD55-LC1 }}$}

$$
N_{c}=0,228 x 933 \times 450=95.725,8 N \rightarrow 95,73 K N
$$

Verificando a desigualdade $M_{p r} \leq M_{p a_{L}}$ :

$$
M_{p r}=1,25 x 699 x\left(1-\frac{95,73}{300}\right)=594,9 \mathrm{KN} . \mathrm{cm}<M_{p a_{L}}=699 \mathrm{KN} . \mathrm{cm}(\mathrm{OK})
$$

Calcula-se o momento resistente médio $\left(M_{l, R m}\right)$ por meio equação 6.24.

$$
\begin{gathered}
M_{l, R m}=N_{c}\left[h_{t}-0,5 \frac{N_{c}}{f_{c} b_{L}}-e_{p}+\left(e_{p}-e\right) \frac{N_{c}}{N_{p a}}\right]+M_{p r} \\
M_{l, R m}=95,73 x\left[11,35-0,5 \frac{95,73}{3,645 x 93,3}-2,75\right]+594,9=1.404,7 \mathrm{KN} . \mathrm{cm}
\end{gathered}
$$


Finalmente, o valor $V_{l, R m}$ é determinado pela equação 6.26.

$$
V_{l, R m}=\frac{M_{l, R m}}{L_{S}}=\frac{1.404,7}{45}=31,2 K N
$$

\section{MD55-LC2}

$$
N_{c}=0,228 x 940,7 \times 900=193.031,6 N \rightarrow 193 K N
$$

Verificando a desigualdade $\mathrm{M}_{\mathrm{pr}} \leq M_{p a_{L}}$ :

$$
M_{p r}=1,25 x 699 x\left(1-\frac{193}{300}\right)=311,64 K N . c m<M_{p a_{L}}=699 \mathrm{KN} . \mathrm{cm}(\mathrm{OK})
$$

Calculando-se o momento resistente médio $\left(M_{l, R m}\right)$ :

$$
M_{l, R m}=193 x\left[17,18-0,5 \frac{193}{3,645 \times 94,7}-2,75\right]+311,64=3.042,7 \mathrm{KN} . \mathrm{cm}
$$

Finalmente, o valor $V_{l, R m}$ é determinado por:

$$
V_{l, R m}=\frac{M_{l, R m}}{L_{S}}=\frac{3.042,7}{90}=33,8 \mathrm{KN}
$$

Com o objetivo de validar a tensão cisalhante média $\left(\tau_{u, m}\right)$ determinada pela aplicação do método da interação parcial, a Tabela 6.6 apresenta uma análise comparativa entre os valores das forças cortantes útimas obtidos experimentalmente $\left(V_{t}\right)$ e pelo método em questão $\left(V_{l, R m}\right)$.

Tabela 6. 6. Análise comparativa entre as forças cortantes útimas experimentais (Vt) e as obtidas pelo método da interação parcial $\left(\mathrm{V}_{1, \mathrm{Rm}}\right)$.

\begin{tabular}{|c|c|c|c}
\hline Protótipo & $\begin{array}{c}\text { Experimental } \\
\mathrm{V}_{\mathrm{t}}(\mathrm{kN})\end{array}$ & $\begin{array}{c}\text { Teórico } \\
\text { (Interação Parcial) } \\
V_{l, R m}(\mathrm{kN})\end{array}$ & $\begin{array}{c}\text { Experimental / } \\
\text { Teórico }\end{array}$ \\
\hline MD55-LC1 & 37,0 & 31,2 & 1,18 \\
\hline MD55-LC2 & 30,4 & 33,8 & 0,90 \\
\hline \multicolumn{3}{|c|}{ Fonte: Autora (2020) }
\end{tabular}

Pode-se notar que os valores teóricos obtidos pela aplicação do método da interação parcial ficaram próximos dos valores experimentais. 


\subsection{INFLUÊNCIA DO CONECTOR DE CISALHAMENTO NA RESISTÊNCIA DE LAJES MISTAS}

Ao considerar os efeitos da presença dos conectores de cisalhamento, verifica-se um ganho na resistência ao cisalhamento longitudinal devido ao aumento da interação na interface açoconcreto. As Tabelas 6.7 e 6.8 apresentam, respectivamente, a análise comparativa entre os valores da relação entre o momento fletor solicitante experimental e o momento fletor resistente para interação total e dos valores experimentais e teóricos da força cortante resistente.

Tabela 6. 7. Momento fletor solicitante experimental versus momento fletor resistente para interação total das lajes sem e com conectores de cisalhamento.

\begin{tabular}{|c|c|c|c|}
\hline Protótipo & $\frac{M_{\text {exp }}}{M_{p R m}}$ (Médio) & Protótipo & $\frac{M_{\exp }}{M_{p R m}}$ \\
\hline MD55-L1 & \multirow{4}{*}{0,53} & \multirow{4}{*}{ MD55-LC1 } & \multirow{4}{*}{0,68} \\
\hline MD55-L2 & & & \\
\hline MD55-L3 & & & \\
\hline MD55-L4 & & & \\
\hline MD55-L5 & \multirow{3}{*}{0,55} & \multirow{3}{*}{ MD55-LC2 } & \multirow{3}{*}{0,65} \\
\hline MD55-L6 & & & \\
\hline MD55-L8 & & & \\
\hline
\end{tabular}

Fonte: Autora (2020)

Tabela 6. 8. Análise comparativa experimental e teórica da força cortante resistente.

\begin{tabular}{|c|c|c|c|c|c|c|c|}
\hline \multirow{2}{*}{ Protótipo } & \multirow{2}{*}{$\begin{array}{c}\text { Exp. } \\
\text { Vt }_{t} \\
\text { (Médio) }\end{array}$} & \multirow{2}{*}{$\begin{array}{c}\text { Teórico } \\
\text { (método } \\
\boldsymbol{m}-\boldsymbol{k} \text { ) } \\
V_{l, R m} \\
\text { (Médio) }\end{array}$} & \multirow{2}{*}{ Protótipo } & \multirow{2}{*}{$\begin{array}{c}\text { Exp. } \\
\text { Vt }_{\text {t }} \\
\text { (Médio) }\end{array}$} & \multirow{2}{*}{$\begin{array}{c}\text { Teórico } \\
\text { Interação } \\
\text { Parcial } \\
V_{l, R m}\end{array}$} & \multicolumn{2}{|c|}{$\begin{array}{c}\text { Com } \\
\text { conectore/Sem } \\
\text { conectores } \\
\end{array}$} \\
\hline & & & & & & Exp. & Teórico \\
\hline $\begin{array}{l}\text { MD55-L1 } \\
\text { MD55-L2 } \\
\text { MD55-L3 } \\
\text { D55-L4 }\end{array}$ & 21,16 & 21,09 & $\begin{array}{l}\text { MD55- } \\
\text { LC1 }\end{array}$ & 37,0 & 31,2 & 1,75 & 1,48 \\
\hline $\begin{array}{l}\text { MD55-L5 } \\
\text { MD55-L6 } \\
\text { MD55-L8 }\end{array}$ & 19,21 & 19,27 & $\begin{array}{c}\text { MD55- } \\
\text { LC2 }\end{array}$ & 30,4 & 33,8 & 1,58 & 1,75 \\
\hline
\end{tabular}


Fonte: Autora (2020)

De acordo com os valores apresentados na Tabela 6.7, pode-se constatar um aumento da interação na interface aço-concreto, uma vez que os valores de momento fletor solicitante experimental das lajes com conectores de cisalhamento apresentaram valores mais próximos do momento fletor resistente para interação total. Além disso, os valores apresentados na Tabela 6.8 mostram um aumento significativo na resistência ao cisalhamento longitudinal tanto na análise experimental quanto teórica. 


\section{CONCLUSÕES E PROPOSTAS PARA TRABALHOS FUTUROS}

O objetivo deste trabalho foi avaliar a influência dos conectores de cisalhamento nas lajes mistas a. Para atingir esse objetivo foram realizados ensaios de flexão de lajes mistas de acordo com as prescrições do EUROCODE 4 (2004) em dez protótipos, sendo oito sem conectores de cisalhamento e dois com conectores, variando-se a altura e o vão. Desta forma, foi possível analisar e comparar os resultados obtibos para as duas séries.

A análise do comportamento estrutural dos protótipos foi realizada com base nas curvas força $\mathrm{x}$ deslizamento relativo de extremidade, força $\mathrm{x}$ flecha, força $\mathrm{x}$ deformação no aço e força $\mathrm{x}$ deformação no concreto obtidas das medições realizadas durante os ensaios. Foram instrumentados dois protótipos sem conectores e dois com conetores com dimensões respectivamente iguais.

Os resultados revelaram que os protótipos apresentaram interação completa nos níveis iniciais de força aplicada e brusco deslizamento relativo entre a fôrma de aço e o concreto em uma das extremidades, precedido por fissuras iniciadas na região de aplicação de força e do lado em que ocorreu o deslizamento, caracterizando a ruptura por cisalhamento longitudinal. No entanto, os protótipos MD55-L7 e MD55-L8 apresentaram comportamento atípico, sendo o MD55-L7 desconsiderado nas análises e o MD55-L8 utilizado com valor reduzido da área efetiva da fôrma.

De acordo com as curvas apresentadas pôde-se observar que a força necessária para romper a aderência química na interface aço-concreto não foi influenciada pela existência da ancoragem de extremidade, uma vez que os valores obtidos para os protótipos com e sem conectores são próximos. Após a força de deslizamento ser atingida, os conectores de cisalhamento contribuem com resistência ao deslizamento relativo, provocando um aumento de força última.

A análise do comportamento estrutural mostrou que a presença dos conectores de cisalhamento gerou um aumento na ductibilidades dos protótipos. Os oito protótipos sem ancoragem de extremidade apresentaram comportamento frágil e os dois protótipos com conectores apresentaram comportamento dúctil. Além disso, os níveis de deformação da fôrma de aço dos protótipos com conectores foram superiores àqueles sem conectores.

Com o objetivo de verificar o aumento da resistência ao cisalhamento longitudinal foi realizada uma análise comparativa dos valores experimentais e teóricos com base nos valores médios. Tanto os valores obtidos experimentalmente quanto aqueles obtidos pela aplicação do 
método $m-k$ e da interação parcial demonstraram que a força cortante resistente aumentou devido à presença dos conectores nos apoios.

A fim de ampliar os conhecimentos acerca do comportamento e da resistência das lajes mistas com conectores de cisalhamento nos apoios, são apresentadas algumas propostas para trabalhos futuros:

- Influência do número e do dâmetro dos conectores de cisalhamento no comportamento e na resistência das lajes mistas;

- Estudo do comportamento e da resistência do sistema de lajes mistas com continuidade e conectores de cisalhamento nos apoios;

- Análise da influência dos conectores de cisalhamento no estado-limite de serviço das lajes mistas;

- Estudo experimental do comportamento e da resistência de lajes mistas com conectores de cisalhamento nos apoios com base em ensaios em escala reduzida;

- Estudo do comportamento e da resistência do sistema de lajes mistas com conectores de cisalhamento sob altas temperaturas;

- Desenvolvimento de modelos numéricos via MEF para analisar o comportamento e a resistência de um sistema de laje mista considerando a contribuição dos conectores de cisalhamento nos apoios;

- Proposição de uma formulação para o cálculo da resistência de um sistema de laje mista considerando a contribuição dos conectores de cisalhamento nos apoios. 


\section{REFERÊNCIAS BIBLIOGRÁFICAS}

Alva, G. M. S. Sobre o projeto de edifícios em estrutura mista aço-concreto. 2000. 296p. Dissertação (Mestrado em Engenharia de Estruturas) - Escola de Engenharia de São Carlos, Universidade de São Paulo, São Carlos, 2000.

AMERICAN NATIONAL STANDARDS INSTITUTE/AMERICAN SOCIETY OF CIVIL ENGINEERS. ANSI/ASCE 3-91: Standard for the structural design of composite slabs. New York, 1992.

AMERICAN NATIONAL STANDARDS INTITUTE/STEEL DECK INSTITUTE. ANSI/SDI C2011: Standard for composite steel floor deck-slabs. Ohio, 2011.

AMERICAN IRON AND STEEL INSTITUTE. North American Specification for the Design of ColdFormed Steel Structural Members. AISI-S100. Washington, 2007.

AMERICAN SOCIETY FOR TESTING AND MATERIALS. ASTM A370-14: Standard methods and definitions for mechanical testing of steel products. West Conshohocken, Pennsylvania, United States of America, $2014.50 \mathrm{p}$.

ASSOCIAÇÃO BRASILEIRA DE NORMAS TÉCNICAS. NBR 14323: Dimensionamento de Estruturas de Aço de Edifícios em Situação de Incêndio — Procedimento. Rio de Janeiro, 2013.

ASSOCIAÇÃO BRASILEIRA DE NORMAS TÉCNICAS. NBR 6118: Projeto de estruturas de concreto - procedimento. Rio de Janeiro, 2014.

ASSOCIAÇÃO BRASILEIRA DE NORMAS TÉCNICAS. NBR 8522: Determinação dos módulos estáticos de elasticidade e de deformação à compressão. Rio de Janeiro, 2017.

ASSOCIAÇÃO BRASILEIRA DE NORMAS TÉCNICAS. NBR 8800: Projeto de estruturas de aço e de estruturas mistas de aço e concreto de edifícios. Rio de Janeiro, 2008.

ASSOCIAÇÃO BRASILEIRA DE NORMAS TÉCNICAS. NBR 14762: Dimensionamento de estruturas de aço constituídas por perfis formados a frio. Rio de Janeiro, 2010. 
ASSOCIAÇÃO BRASILEIRA DE NORMAS TÉCNICAS. NBR 5739: Concreto - Ensaio de compressão de corpos-de-prova cilíndricos. Rio de Janeiro, 2007.

ASSOCIAÇÃO BRASILEIRA DE NORMAS TÉCNICAS. NBR 7008-3: Chapas e bobinas de aço revestidas com zinco ou liga zinco-ferro pelo processo contínuo de imersão a quente. Parte 3: Aços estruturais. Rio de Janeiro, 2012.

BELTRÃO, A. J. N. Comportamento Estrutural de Lajes-mistas com Corrugações na Alma de Perfis de Chapa Dobrada. 2003. 124p. Dissertação (Mestrado) - Departamento de Engenharia Civil, Pontifícia Universidade Católica do Rio de Janeiro, Rio de Janeiro, 2003.

CAMPOS, P. C. Efeito da continuidade no comportamento e na resistência de lajes mistas com fôrma de aço incorporada. 2001. 143 p. Dissertação (Mestrado em Engenharia de Estruturas) - Escola de Engenharia, Universidade Federal de Minas Gerais, Belo Horizonte, 2001.

CHEN, L. Z. Load carrying capacity of composite slabs with various constraints. In: Journal of Constructional Steel Research. p.385-403, 2003.

CHEN, L. Z.; RANZI, G.; JIANG, S. C. TAHMASEBINIA, F.; LI, G. Q. Behaviour and design of shear connectors in composite slabs at elevated temperatures. In: Journal of Constructional Steel Research. p.387$397,2015$.

CORDEIRO, L. C. S. Sobre as lajes mistas de aço e concreto em situação de incêndio. 2014. 262p. Dissertação (Mestrado em Engenharia de Estruturas) - Escola Politécnica de São Paulo, Universidade de São Paulo, São Paulo, 2014.

COSTA, R. S. Análise de um sistema de lajes mistas considerando a influência do atrito dos apoios e a avaliação do momento de inercia efetivo. 2009. 217p. Dissertação (Mestrado em Engenharia de Estruturas) - Escola de Engenharia, Universidade Federal de Minas Gerais, Belo Horizonte, 2009.

CANADIAN SHEET STEEL BUILDING INSTITUTE. CSSBI S3-2008: Criteria for the design of composite slabs. Cambridge, Ontario, 2008. 
DEGTYAREV, V. V. Strength of composite slabs with end anchorages. Part I: Analytical model. In: Journal of Constructional Steel Research. p.150-162, 2014.

DEGTYAREV, V. V. Strength of composite slabs with end anchorages. Part II: Parametric studies. In: Journal of Constructional Steel Research. p.163-175, 2014.

DIAS, L. A. M. Estruturas híbridas e mistas de aço e concreto. 1. Ed. Editora São Paulo. São Paulo, 2014.

EUROPEAN COMMITTEE FOR STANDARDIZATION. EN 1994-1-1: Eurocode 4 - Design of composite steel and concrete structures - Part 1-1: General rules for buildings. Bruxelas, Bélgica, 2004.

FRIBERG, B. F. Combined form and reinforcement for concrete slabs. American Concrete Institute Journal, Denver, Colorado, United States of America, v. 25, n. 9, p. 697-716, 1954.

FRIEDRICH, J. T. Análise teórico-experimental de pisos de pequena altura. 2012. 128p. Dissertação (Mestrado em Engenharia de Estruturas) - Escola de Engenharia de São Carlos, Universidade de São Paulo, São Carlos, 2012.

GOMES, L. C. Estudo do sistema de lajes mistas com fôrma de aço incorporada empregando concreto estrutural leve. 2001. 165p. Dissertação (Mestrado em Engenharia de Estruturas) Universidade Federal de Minas Gerais, Belo Horizonte, 2001.

GROSSI, L. G. F. Sobre o comportamento estrutural e o dimensionamento de lajes mistas de aço e concreto com armadura adicional. 2016. 279p. Dissertação (Mestrado em Engenharia de Estruturas) - Escola de Engenharia de São Carlos, Universidade de São Paulo, São Carlos, 2016.

HEAGLER, R. B. The steel deck institute method for designing composite slabs. Thin-Walled Structures, Great Britain, v. 16, n. 1-4, p. 319-326, 1993.

JOHNSON, R. P. Composite structures of steel and concrete: Volume 1 -beams, slabs, columns, and frames for buildings. $2^{\mathrm{a}}$ ed. Oxford: BlackwellScientific Publications, 1994. 
MELO, C. B. Análise do comportamento e da resistência do sistema de lajes mistas. 1999. 168p. Dissertação (Mestrado em Engenharia de Estruturas) - Escola de Engenharia, Universidade Federal de Minas Gerais, Belo Horizonte, 1999.

MIRZA, O.; UY, B. Experimental Studies on Short and Long Term Behaviour for Composite SteelConcrete Slabs. In: Proceedings of the $10^{\text {th }}$ International Conference on Advances in Steel Comcrete Composites and Hybrid Structures. p.485-492, 2012.

MODULAR. (Catálogo) Modular Sistemas Construtivos: Modular Deck MD 55. 2014.

MORAIS OLIVEIRA, L. A. Comportamento em serviço de lajes mistas de aço e concreto ao longo do tempo. 2019. 250p. Dissertação (Mestrado em Engenharia de Estruturas) - Escola de Engenharia de São Carlos, Universidade de São Paulo, São Carlos, 2019.

QUEIROZ, G.; PIMENTA, R.; J; MARTINS, A. G. Estruturas mistas. v.1, 68p. Rio de Janeiro: Instituto Aço Brasil/Centro Brasileiro da Construção em Aço (CBCA), 2012.

QUEIROZ, G.; PIMENTA, R. J.; DA MATA, L. A. C. Elementos das estruturas mistas aço-concreto. 336p. Belo Horizonte: O Lutador, 2001.

RANA, M. M.; UY, B.; MIRZA, O. Experimental and numerical study of end Anchorage in composite slabs. In: Journal of Constructional Steel Research. p.372-386, 2015.

SANTOS, D. B. R. Modelagem numérica de lajes mistas de aço e concreto em situação de incêndio. 2014. 243p. Dissertação (Mestrado em Engenharia de Estruturas) - Escola de Engenharia de São Carlos, Universidade de São Paulo, São Carlos, 2014.

SCHUSTER, R. M. Strength and behaviour of cold-rolled steel-deck reinforced concrete floor slabs. 1970. 229p. Ph. D. Thesis (Structural Engineering) - Iowa State University of Science and Technology, Amess, Iowa, United States of America, 1970. 
SCHUSTER, R. M.; LING, W. C. Mechanical interlocking capacity of composite slabs. $\mathbf{5}^{\text {th }}$ International Specialty Conference on Cold-Formed Steel Structures, Saint Louis, Missouri, United States of America, p. 387-407, 1980.

SCHUSTER, R. M.; SELEIM, S. S. Shear-bond capacity of composite slabs. $6^{\text {th }}$ International Specialty Conference on Cold-Formed Steel Structures, Saint Louis, Missouri, United States of America, p. $511-531,1982$.

SIEG, A. P. A. Estudo de um sistema de laje com fôrma de aço incorporada. 2015. 143p. Dissertação (Mestrado em Engenharia de Estruturas) - Escola de Engenharia de São Carlos, Universidade de São Paulo, São Carlos, 2015.

SILVA, H. J. F. Análise do sistema de laje mista com fôrma incorporada aplicado a estruturas prediais em concreto armado. 1999. 149p. Dissertação (Mestrado em Engenharia de Estruturas) Escola de Engenharia, Universidade Federal de Minas Gerais, Belo Horizonte, 1999.

SOUZA NETO, A. S. Análise do comportamento e da resistência de um sistema de lajes mistas com ancoragem de extremidade com considerações sobre a fôrma de aço isolada e atrito nos apoios. 2001. 211 p. Dissertação (Mestrado em Engenharia de Estruturas) - Universidade Federal de Minas Gerais, Belo Horizonte, 2001.

TAKEY, T. H. Sistemas de Laje Mista para Edificações com uso de Perfis de Chapa Metálica. 2001. 181p. Dissertação (Mestrado) - Departamento de Engenharia Civil, Pontifícia Universidade Católica do Rio de Janeiro, Rio de Janeiro, 2001.

TRISTÃO, G. A. Comportamento de conectores de cisalhamento em vigas mistas aço-concreto com análise da resposta numérica. 2002. 146p. Dissertação (Mestrado em Engenharia de Estruturas) - Escola de Engenharia de São Carlos, Universidade de São Paulo, São Carlos, 2002.

VIANNA, J. C. Sistema de laje-mista para edificações residenciais com o uso de perfis embossados de chapa dobrada. 2005. 189p. Dissertação (Mestrado) - Departamento de Engenharia Civil, Pontifícia Universidade Católica do Rio de Janeiro, Rio de Janeiro, 2005. 
VIEIRA, J. D. Estudo teórico-experimental do comportamento de lajes mistas com perfis incorporados de aço. Rio de Janeiro. 2003. 121p. Dissertação (Mestrado) - Departamento de Engenharia Civil, Pontifícia Universidade Católica do Rio de Janeiro, Rio de Janeiro, 2003.

WIDJAJA, B. R. Analysis and design of steel deck concrete composite slabs. 1997. 96p. Ph. D.

Thesis (Civil Engineering) - Virginia Polytechnic Institute and State University, Blacksburg, Virginia, United States of America, 1997. 
APÊNDICE A - RELATÓRIO FOTOGRÁFICO

Figura A. 1. Protótipos preparados para concretagem.

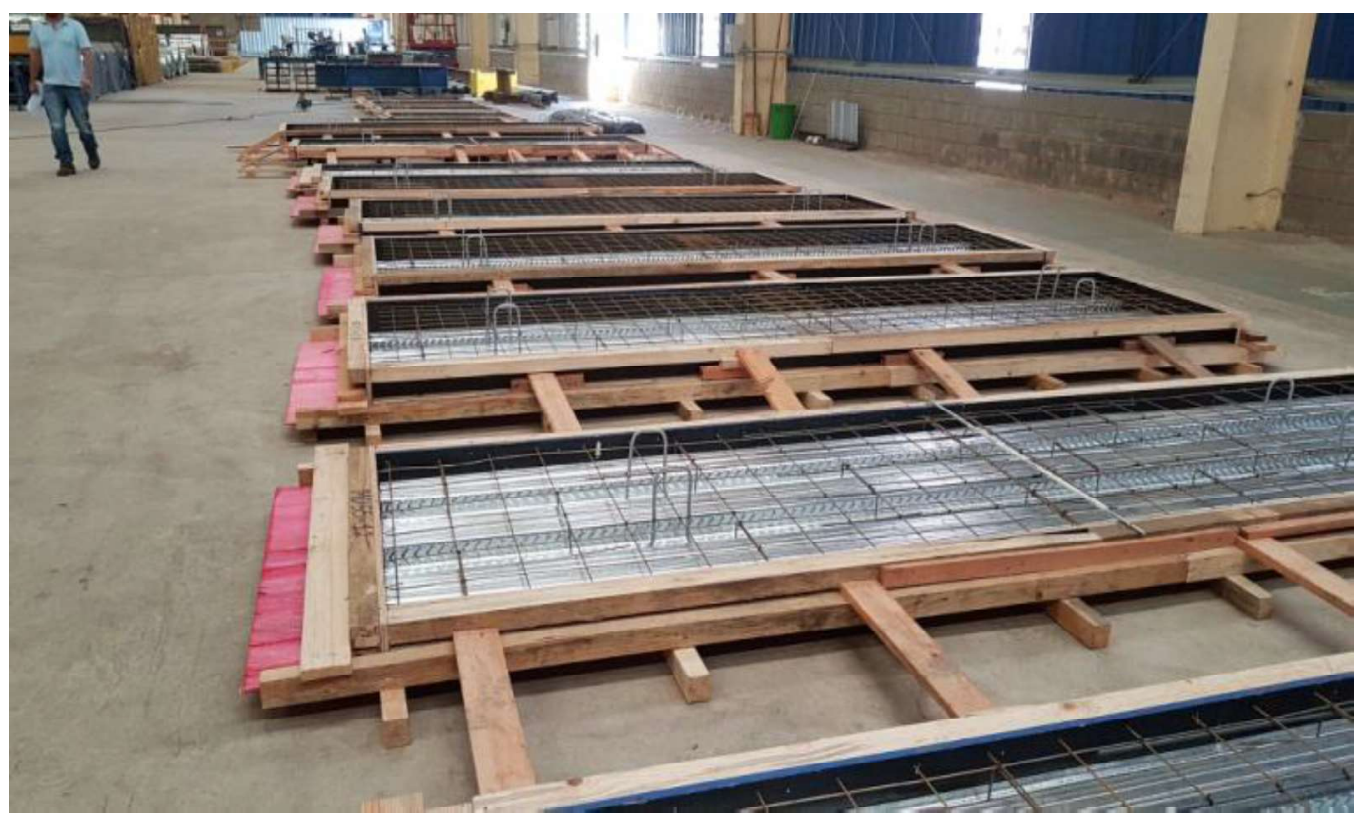

Fonte: Modular (2018)

Figura A. 2. Concretagem dos protótipos.

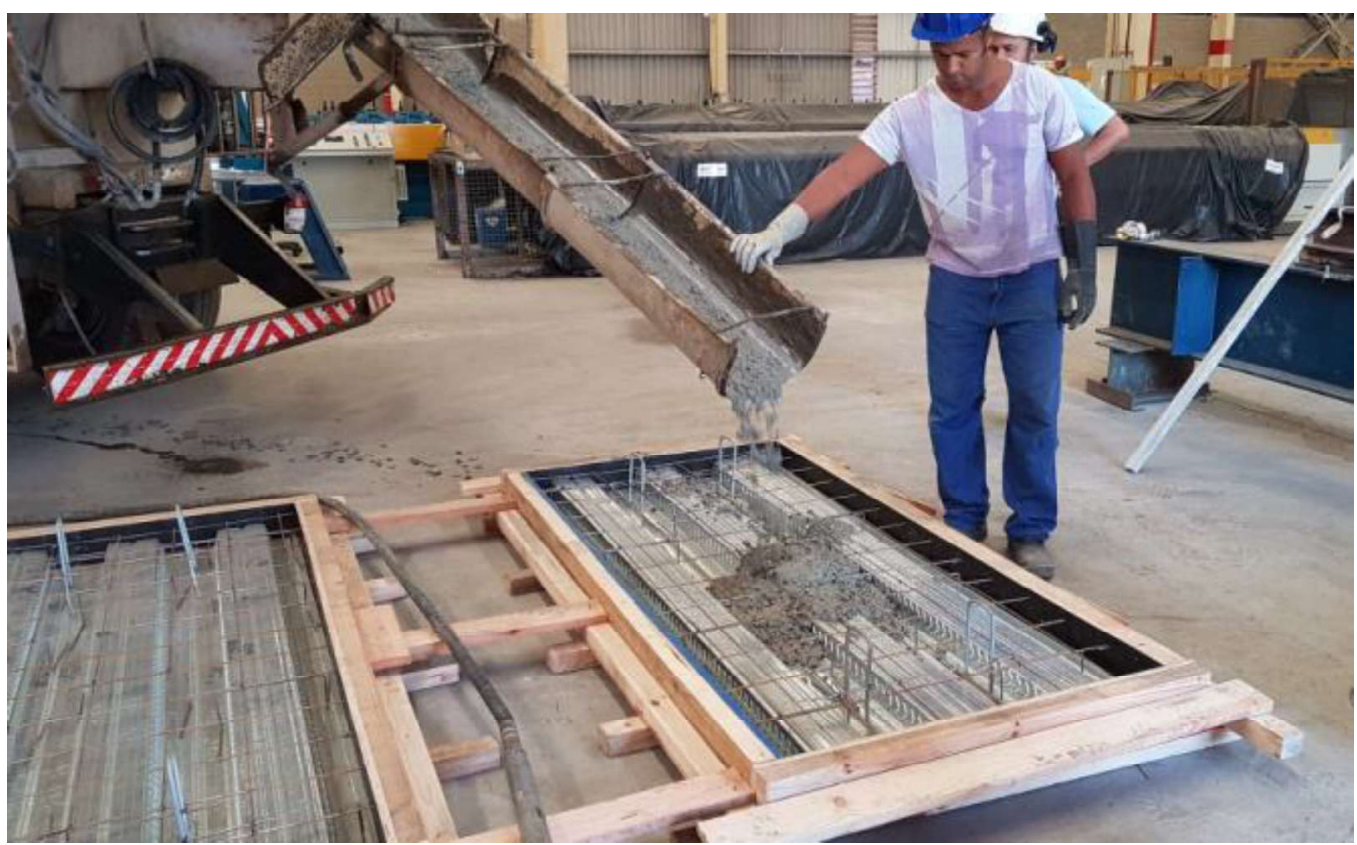

Fonte: Modular (2018) 
Figura A. 3. Vista geral do ensaio: protótipo sem conectores de cisalhamento com vão teórico de $1.800 \mathrm{~mm}$.

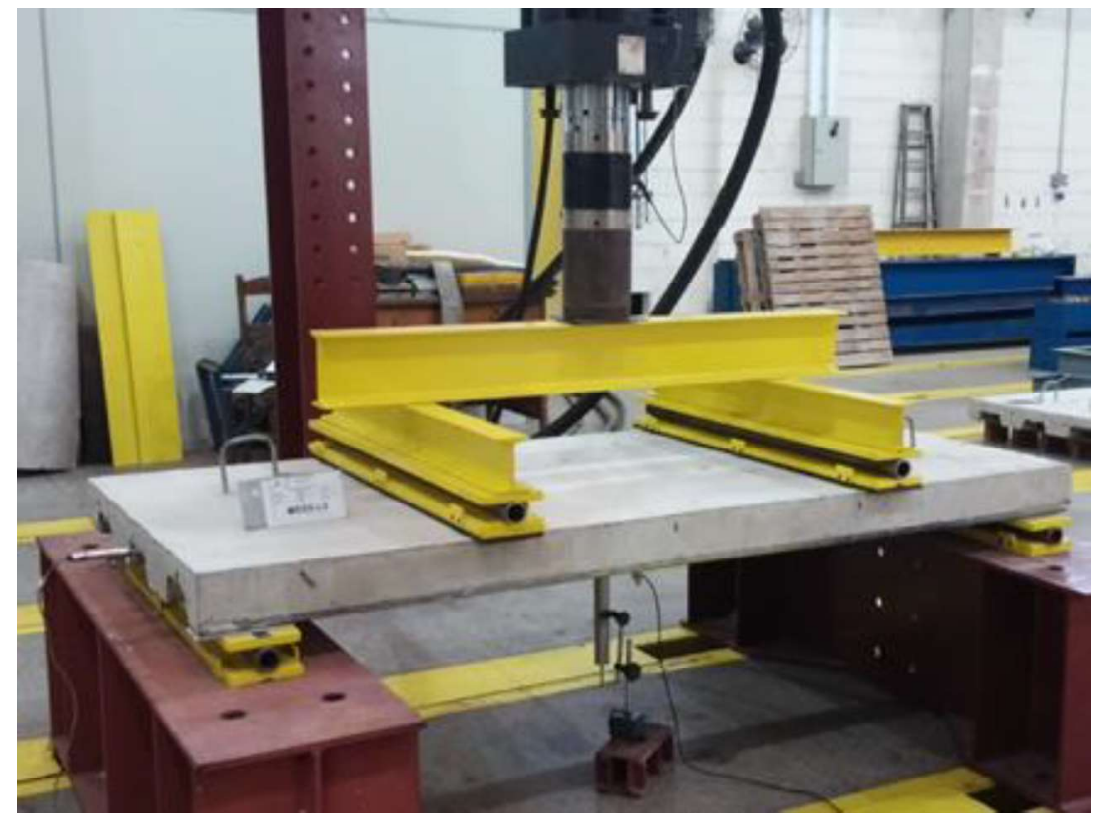

Fonte: Autora (2020)

Figura A. 4. Vista geral do ensaio: protótipo sem conectores de cisalhamento com vão teórico de $3.600 \mathrm{~mm}$.

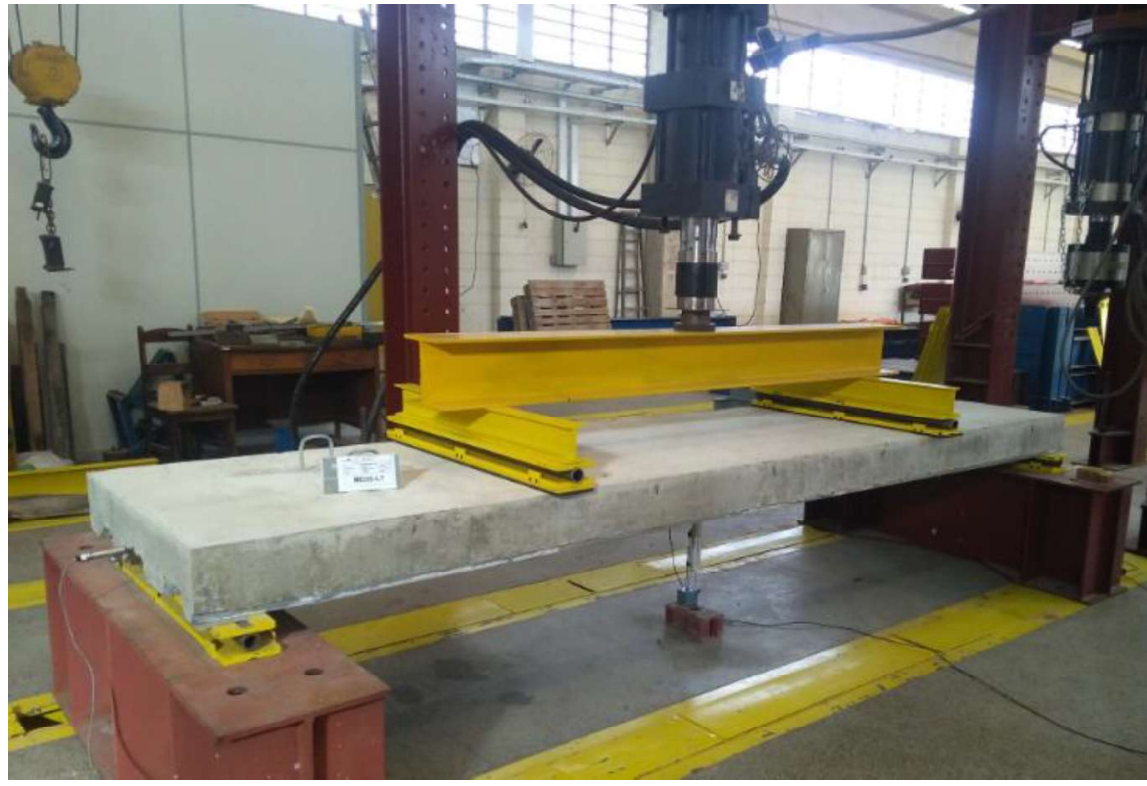

Fonte: Autora (2020) 
Figura A. 5. Vista geral do ensaio: protótipo com conectores de cisalhamento com vão teórico de $1.800 \mathrm{~mm}$.

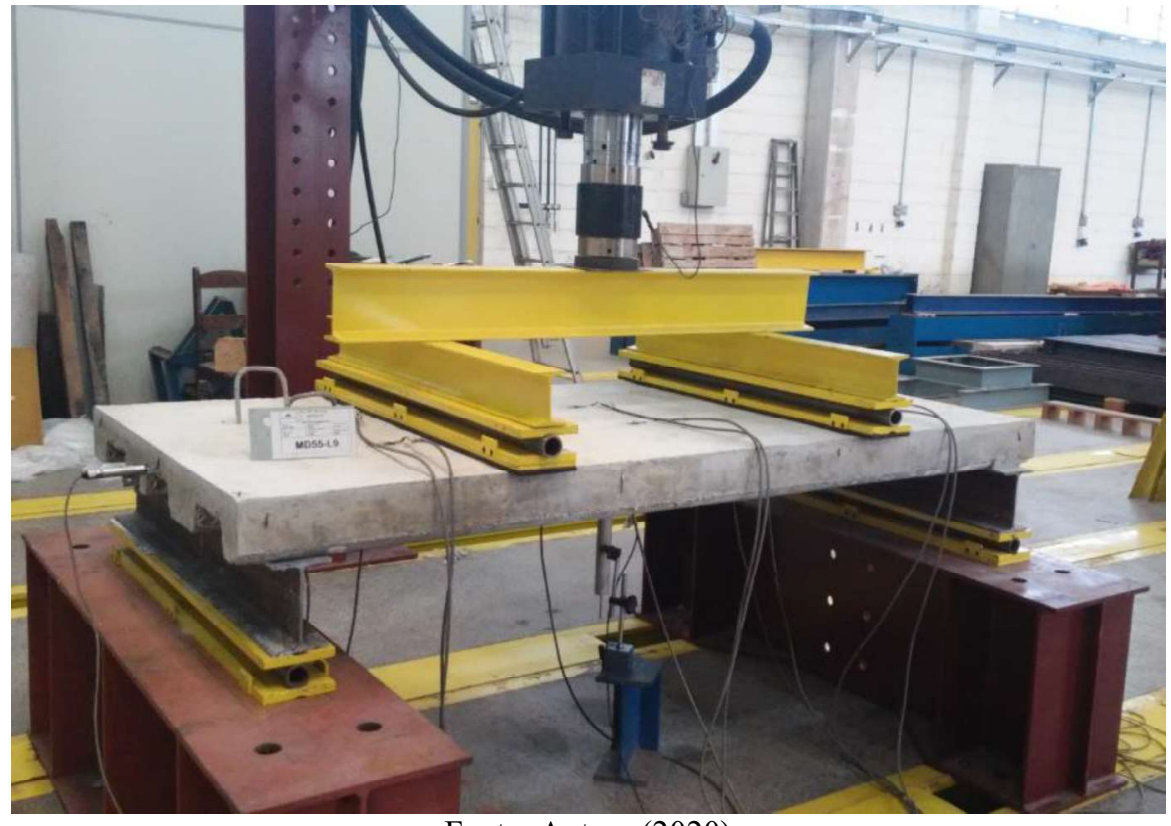

Fonte: Autora (2020)

Figura A. 6. Vista geral do ensaio: protótipo com conectores de cisalhamento com vão teórico de $3.600 \mathrm{~mm}$.

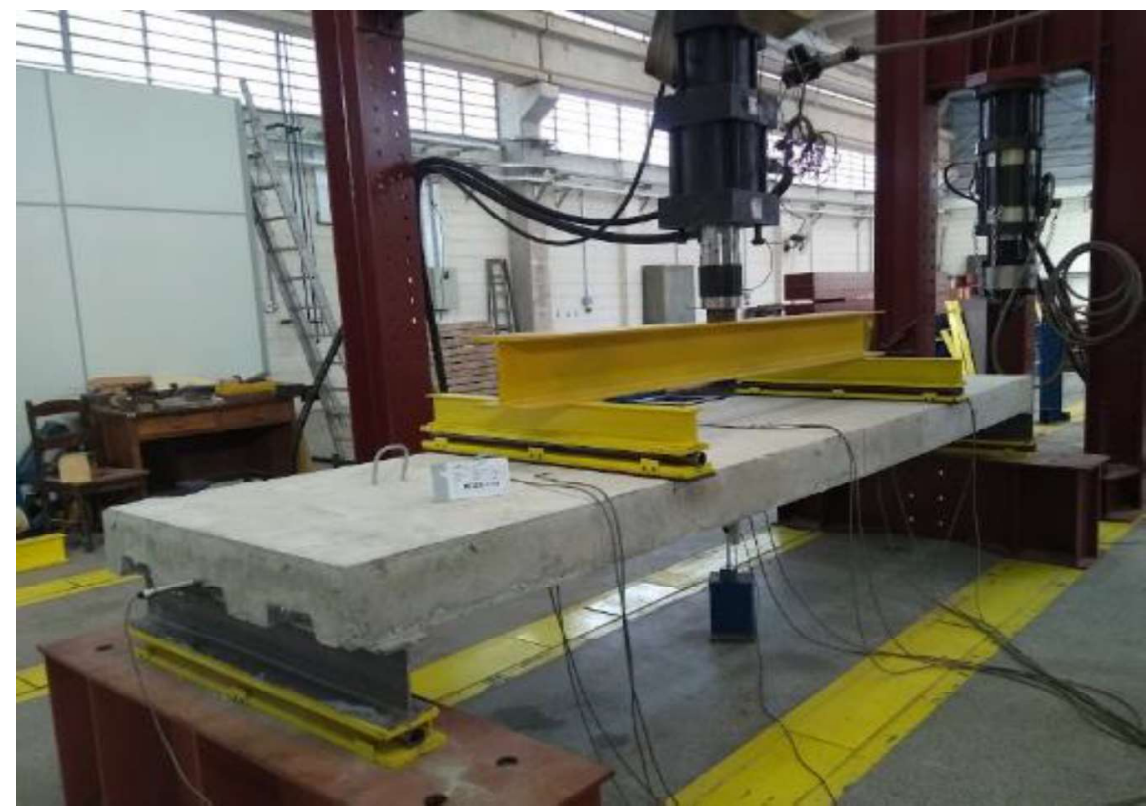

Fonte: Autora (2020) 
Figura A. 7. Detalhe do apoio fixo.

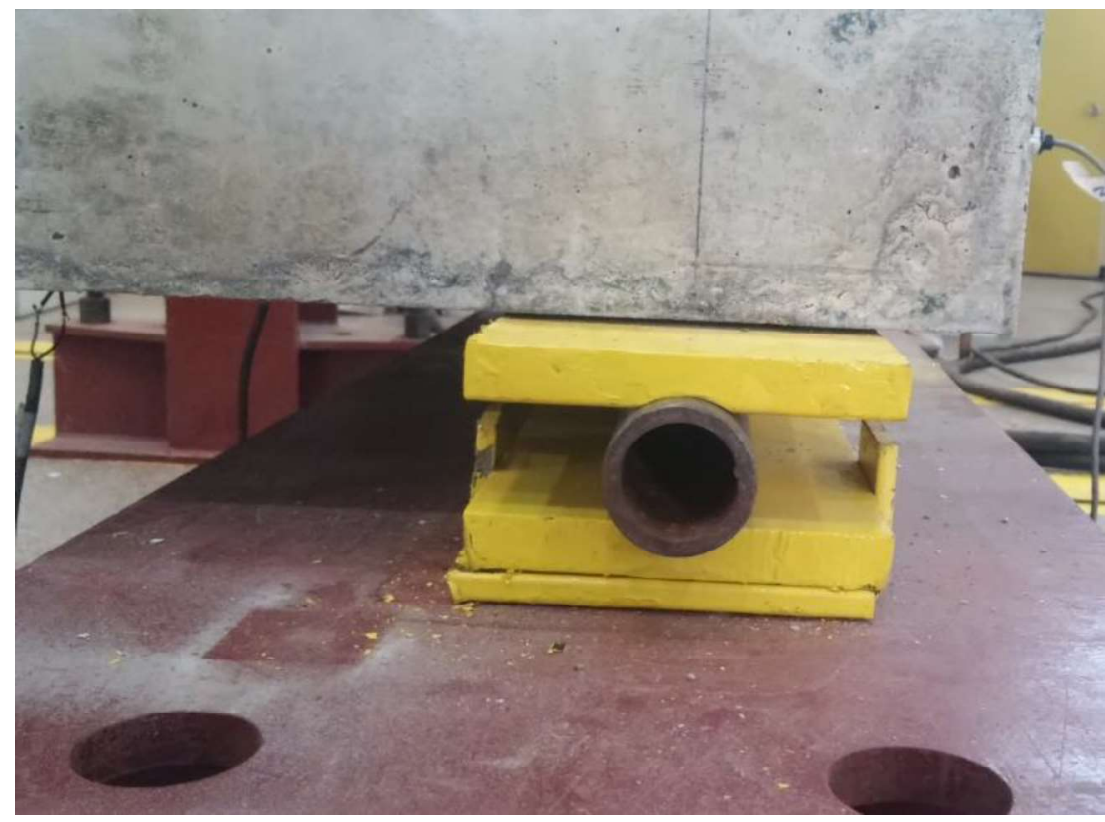

Fonte: Autora (2020)

Figura A. 8. Detalhe do apoio móvel.

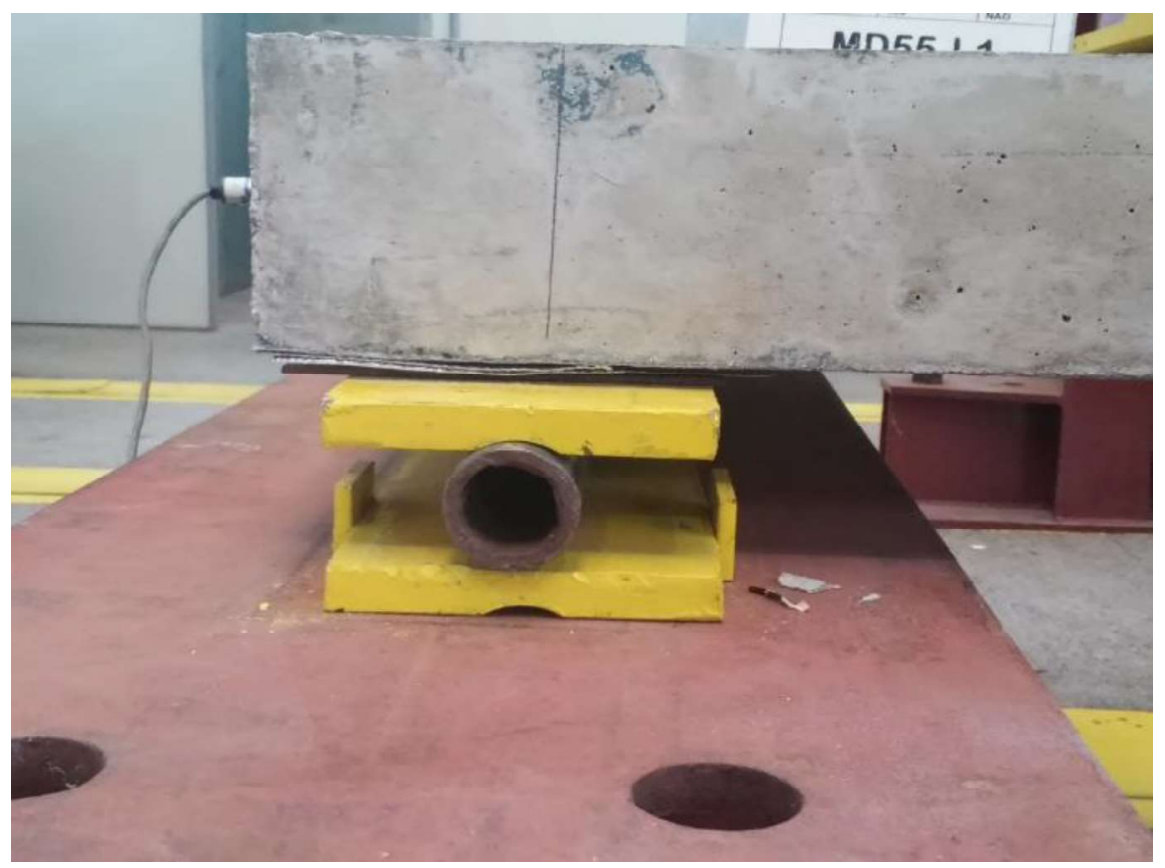

Fonte: Autora (2020) 
Figura A. 9. Transdutor para medição do deslizamento relativo de extremidade.

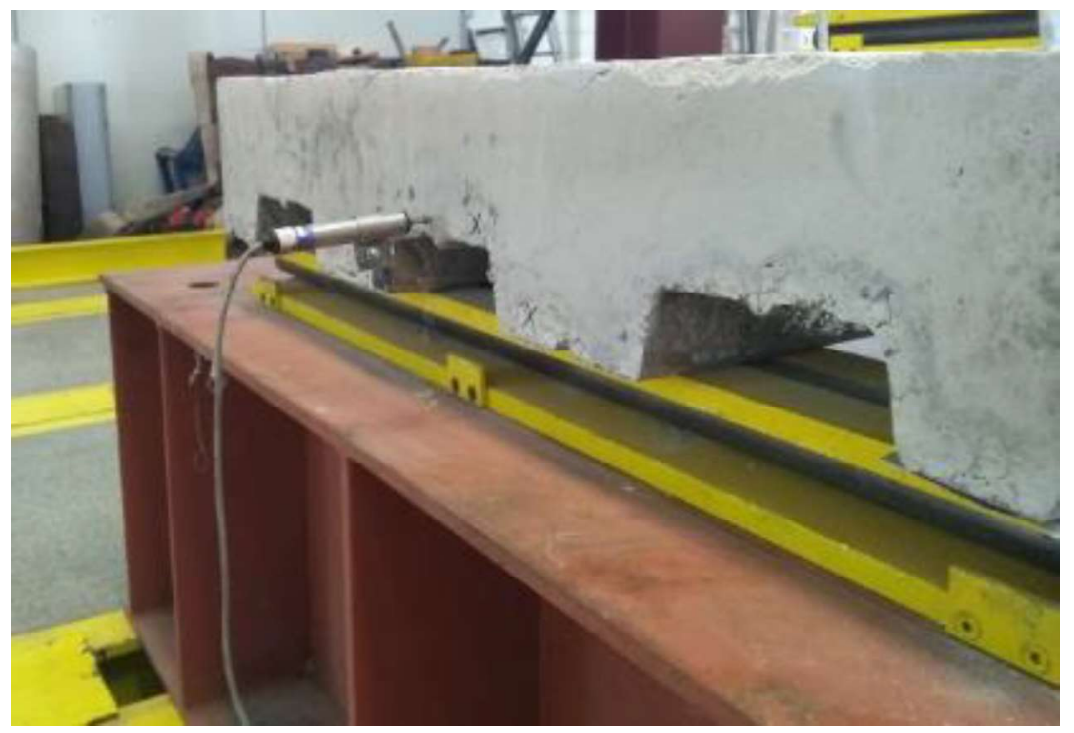

Fonte: Autora (2020)

Figura A. 10. Transdutor para medição da flecha.

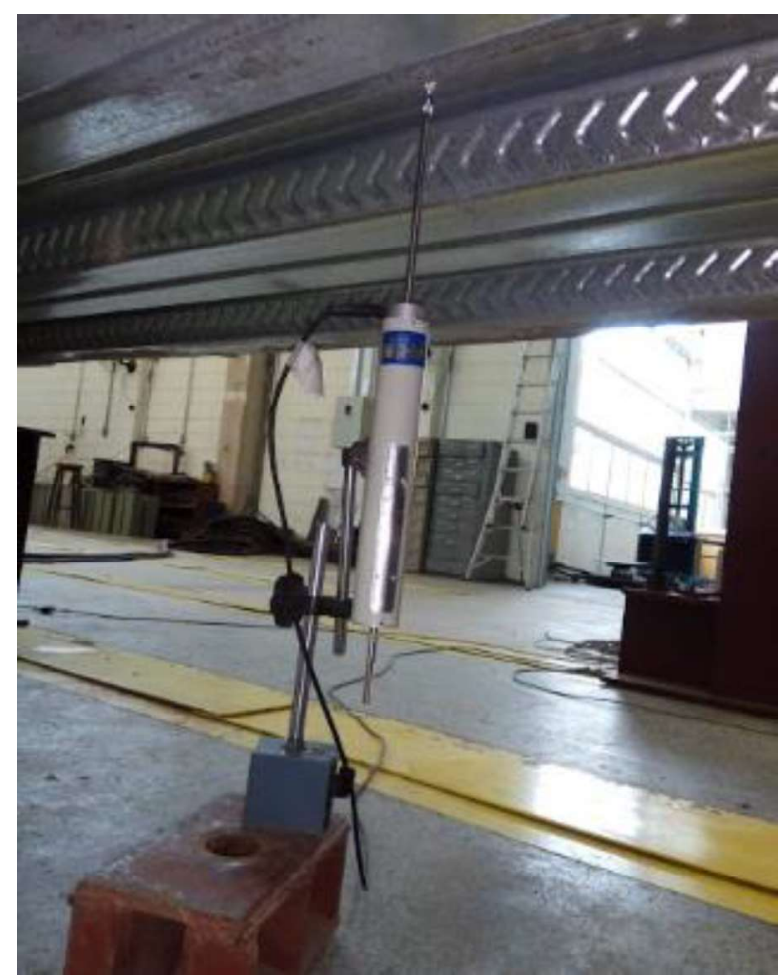

Fonte: Autora (2020) 
Figura A. 11. Extensômetros eléticos na face superior da laje.

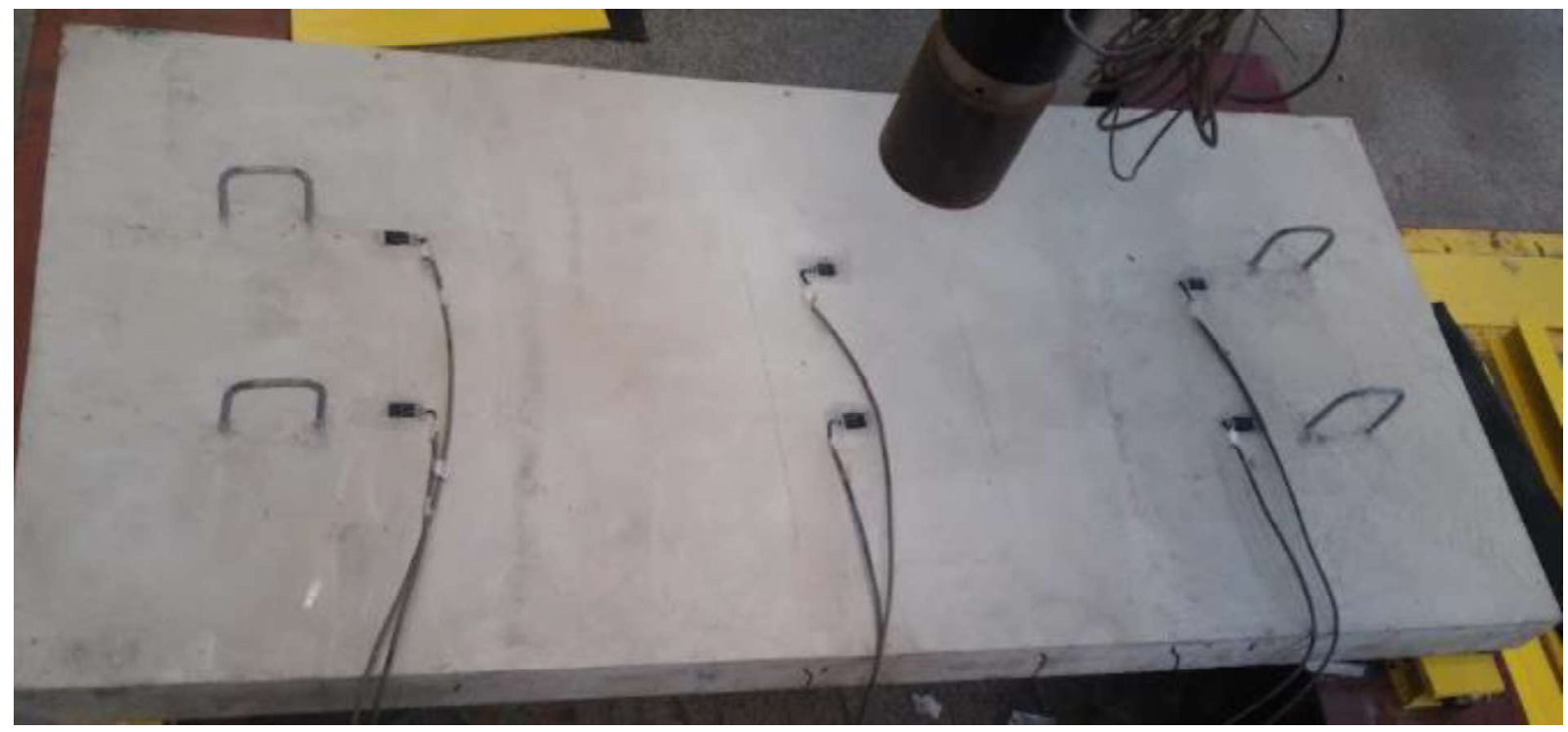

Fonte: Autora (2020)

Figura A. 12. Extensômetros elétricos uniaxiais na fôrma de aço (onda alta e onda baixa).

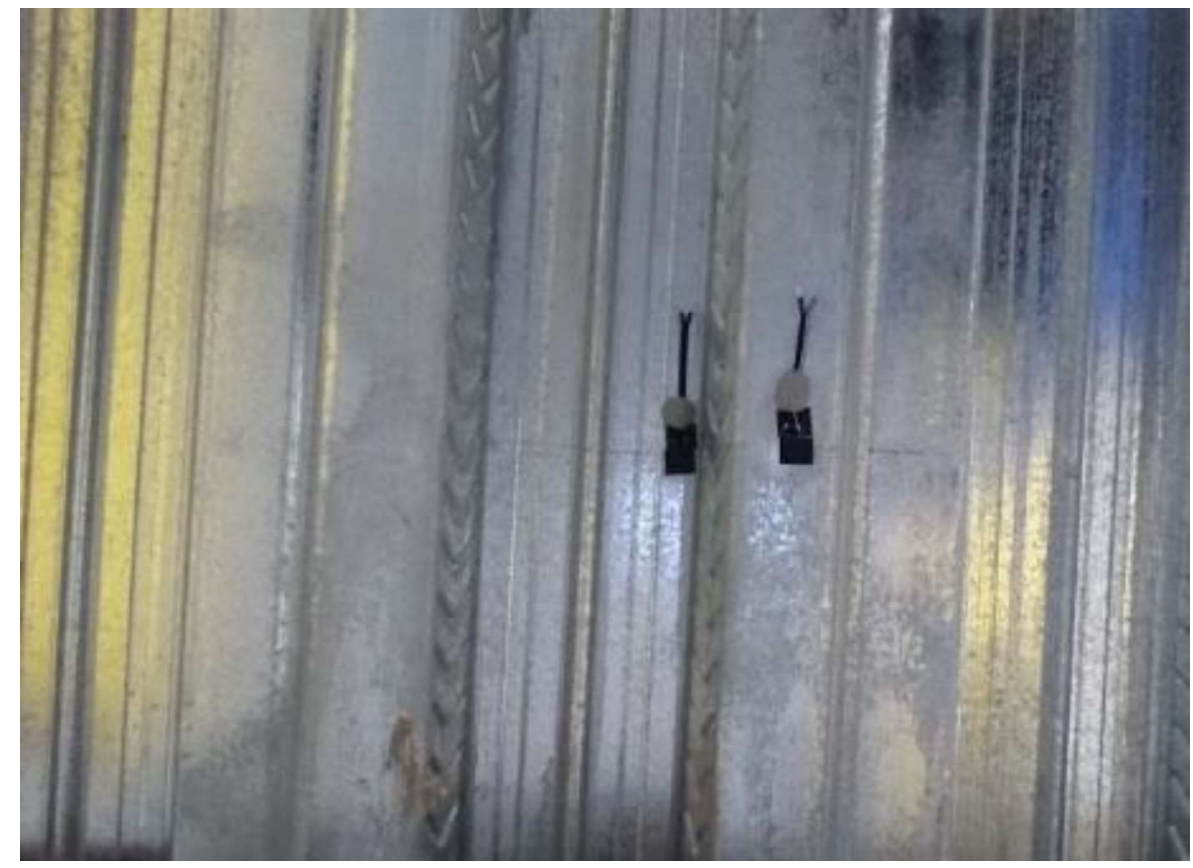

Fonte: Autora (2020) 
Figura A. 13. Aspecto típico da fissura na região da força aplicada, após o deslizamento.

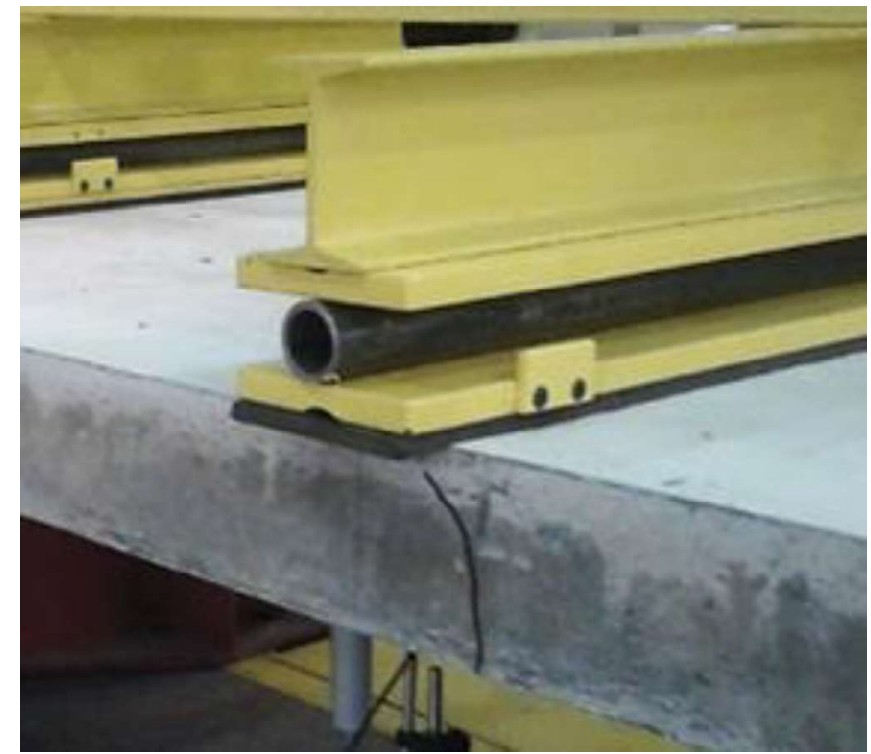

Fonte: Autora (2020)

Figura A. 14. Deslizamento relativo entre o concreto e a fôrma de aço na extremidade.

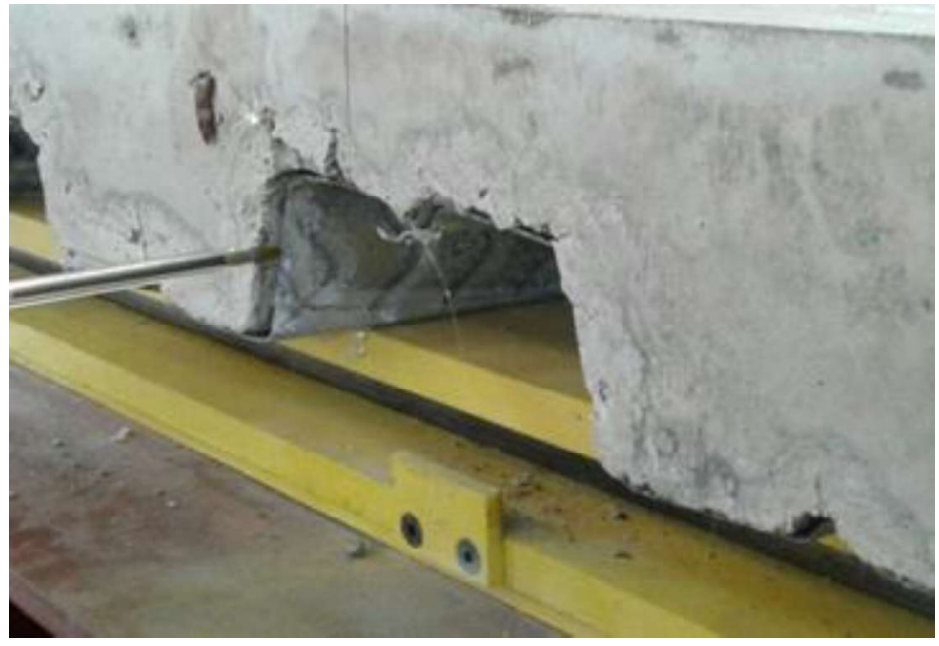

Fonte: Autora (2020) 


\section{APÊNDICE B - CÁLCULO DOS DESLOCAMENTOS E DEFORMAÇÕES ESPECÍFICAS}

A Tabelas B.1 apresenta as expressões utilizadas pas a determinação teórica da flecha elástica. Nas Tabelas B.2 e B.3 estão expostas as expressões das deformações específicas baseadas no modelo elástico fissurado e não fissurado, respectivamente.

Tabela B. 1. Relações Força (KN) x Flecha (mm).

\begin{tabular}{c|c|c}
\hline Hipótese & MD55-L1 a MD55-L4 e MD55-LC1 & MD55-L5 a MD55-L8 e MD55-LC2 \\
\hline $\begin{array}{c}\text { Concreto } \\
\text { Tracionado } \\
\text { Fissurado }\end{array}$ & $\delta=\left(\frac{11 \times 1.800^{3}}{768 \times 200.000 \times 3.252 .769}\right)(1.000 F)$ & $\delta=\left(\frac{11 \times 3.600^{3}}{768 \times 200.000 \times 11.288 .885,74}\right)(1.000 F)$ \\
\hline $\begin{array}{c}\text { Concreto } \\
\text { Tracionado } \\
\text { Não } \\
\text { Fissurado }\end{array}$ & $\delta=\left(\frac{11 \times 1.800^{3}}{768 \times 200.000 \times 8.449 .624}\right)(1.000 F)$ & $\delta=\left(\frac{11 \times 3.600^{3}}{768 \times 200.000 \times 29.391 .870,97}\right)(1.000 F)$ \\
\hline $\begin{array}{c}\text { Momento de } \\
\text { Inércia } \\
\text { Médio }\end{array}$ & $\delta=\left(\frac{11 \times 1.800^{3}}{768 \times 200.000 \times 5.851 .196,5}\right)(1.000 F)$ & $\delta=\left(\frac{11 \times 3.600^{3}}{768 \times 200.000 \times 20.340 .378,36}\right)(1.000 F)$ \\
\hline \multicolumn{2}{|c|}{ Fonte: Autora (2020) }
\end{tabular}

Tabela B. 2. Relações Força (KN) x Deformação específica considerando o concreto tracionado fissurado.

(continua)

\begin{tabular}{c|c|c}
\hline Seção & MD55-L1 a MD55-L4 e MD55-LC1 & MD55-L5 a MD55-L8 e MD55-LC2 \\
\hline & $\varepsilon_{c}=\frac{\left(\frac{1.000 F}{2}\right) \times 300}{200.000 \times 3.252 .769}(-33,35) \times 10^{6}$ & $\varepsilon_{c}=\frac{\left(\frac{1.000 F}{2}\right) \times 750}{200.000 \times 11.288 .885,74}(-46,58) \times 10^{6}$ \\
\cline { 2 - 3 } $\begin{array}{c}\text { Seções } \\
\text { S1 e } \\
\text { S3 }\end{array}$ & $\varepsilon_{a i}=\frac{\left(\frac{1.000 F}{2}\right) \times 300}{200.000 \times 3.252 .769}(79.65) \times 10^{6}$ & $\varepsilon_{a i}=\frac{\left(\frac{1.000 F}{2}\right) \times 750}{200.000 \times 11.288 .885,74}(126,17) \times 10^{6}$ \\
\cline { 2 - 3 } & $\varepsilon_{a s}=\frac{\left(\frac{1.000 F}{2}\right) \times 300}{200.000 \times 3.252 .769}(24.64) \times 10^{6}$ & $\varepsilon_{a s}=\frac{\left(\frac{1.000 F}{2}\right) \times 750}{200.000 \times 11.288 .885,74}(71,17) \times 10^{6}$ \\
\hline
\end{tabular}


Tabela B. 2. Relações Força (KN) x Deformação específica $(\varepsilon)^{a}$ considerando o concreto tracionado fissurado (conclusão)

\begin{tabular}{|c|c|c|}
\hline Seção & MD55-L1 a MD55-L4 e MD55-LC1 & MD55-L5 a MD55-L8 e MD55-LC2 \\
\hline \multirow{3}{*}{$\begin{array}{c}\text { Seção } \\
\text { S2 }\end{array}$} & $\varepsilon_{c}=\frac{\left(\frac{1.000 F}{2}\right) \times 450}{200.000 \times 3.252 .769}(-33.35) \times 10^{6}$ & $\varepsilon_{c}=\frac{\left(\frac{1.000 F}{2}\right) \times 900}{200.000 \times 11.288 .885,74}(-46,58) \times 10^{6}$ \\
\hline & $\varepsilon_{a i}=\frac{\left(\frac{1.000 F}{2}\right) \times 450}{200.000 \times 3.252 .769}(79.65) \times 10^{6}$ & $\varepsilon_{a i}=\frac{\left(\frac{1.000 F}{2}\right) \times 900}{200.000 \times 11.288 .885,74}(126,17) \times 10^{6}$ \\
\hline & $\varepsilon_{a s}=\frac{\left(\frac{1.000 F}{2}\right) \times 450}{200.000 \times 3.252 .769}(24.65) \times 10^{6}$ & $\varepsilon_{a s}=\frac{\left(\frac{1.000 F}{2}\right) \times 900}{200.000 \times 11.288 .885,74}(71,17) \times 10^{6}$ \\
\hline $\begin{array}{l}{ }^{a} \varepsilon_{c}: \operatorname{def} \\
\varepsilon_{a i}: \operatorname{def}\end{array}$ & $\begin{array}{l}\text { mação longitudinal específica na face superior } \\
\text { mação longitudinal específica na onda baixa da } \\
\text { mação longitudinal específica na onda alta da } f\end{array}$ & $\begin{array}{l}\text { a capa de concreto; } \\
\text { ôrma de aço; } \\
\text { rma de aço. }\end{array}$ \\
\hline
\end{tabular}

Fonte: Autora (2020)

Tabela B. 3. Relações Força (KN) x Deformação específica considerando o concreto tracionado não fissurado.

(continua)

\begin{tabular}{c|c|c}
\hline Seção & MD55L1-MD55L4 & MD55L5-MD55L8 \\
\hline & $\varepsilon_{c}=\frac{\left(\frac{1.000 F}{2}\right) \times 300}{200.000 \times 8.449 .624}(-33,35) \times 10^{6}$ & $\varepsilon_{c}=\frac{\left(\frac{1.000 F}{2}\right) \times 750}{200.000 \times 29.391 .870,97}(-46,58) \times 10^{6}$ \\
\cline { 2 - 3 } $\begin{array}{c}\text { Seções } \\
\text { S1 e } \\
\text { S3 }\end{array}$ & $\varepsilon_{a i}=\frac{\left(\frac{1.000 F}{2}\right) \times 300}{200.000 \times 8.449 .624}(79.65) \times 10^{6}$ & $\varepsilon_{a i}=\frac{\left(\frac{1.000 F}{2}\right) \times 750}{200.000 \times 29.391 .870,97}(126,17) \times 10^{6}$ \\
\cline { 2 - 3 } & $\varepsilon_{a s}=\frac{\left(\frac{1.000 F}{2}\right) \times 300}{200.000 x 8.449 .624}(24.64) \times 10^{6}$ & $\varepsilon_{a s}=\frac{\left(\frac{1.000 F}{2}\right) \times 750}{200.000 \times 29.391 .870,97}(71,17) \times 10^{6}$ \\
\hline
\end{tabular}


Tabela B. 3. Relações Força (KN) x Deformação específica $(\varepsilon)^{a}$ considerando o concreto tracionado não fissurado (conclusão)

\begin{tabular}{c|c|c}
\hline Seção & MD55L1-MD55L4 & MD55L5-MD55L8 \\
\hline & $\varepsilon_{c}=\frac{\left(\frac{1.000 F}{2}\right) \times 450}{200.000 \times 8.449 .624}(-33.35) \times 10^{6}$ & $\varepsilon_{c}=\frac{\left(\frac{1.000 F}{2}\right) \times 900}{200.000 \times 29.391 .870,97}(-46,58) \times 10^{6}$ \\
\cline { 2 - 3 } $\begin{array}{c}\text { Seção } \\
\text { S2 }\end{array}$ & $\varepsilon_{a i}=\frac{\left(\frac{1.000 F}{2}\right) \times 450}{200.000 \times 8.449 .624}(79.65) \times 10^{6}$ & $\varepsilon_{a i}=\frac{\left(\frac{1.000 F}{2}\right) \times 900}{200.000 \times 29.391 .870,97}(126,17) \times 10^{6}$ \\
\cline { 2 - 3 } & $\varepsilon_{a s}=\frac{\left(\frac{1.000 F}{2}\right) \times 450}{200.000 \times 8.449 .624}(24.65) \times 10^{6}$ & $\varepsilon_{a s}=\frac{\left(\frac{1.000 F}{2}\right) \times 900}{200.000 \times 29.391 .870,97}(71,17) \times 10^{6}$ \\
\hline
\end{tabular}

${ }^{a} \varepsilon_{c}$ : deformação longitudinal específica na face superior da capa de concreto;

$\varepsilon_{a i}$ : deformação longitudinal específica na onda baixa da fôrma de aço;

$\varepsilon_{a s}:$ deformação longitudinal específica na onda alta da fôrma de aço. 


\section{APÊNDICE C - RESULTADOS DOS ENSAIOS}

Neste apêndice são apresentadas as curvas Força x Deslizamento Relativo, Força x Flecha, Força x Deformação no Concreto e Força x Deformação na Fôrma de Aço obtidas da análise teórica e experimental de todos os protótipos.

\section{C.1 CURVAS DO PROTÓTIPO MD55-L1}

Figura C. 1. Curva Força x Deslizamento Relativo do protótipo MD55-L1.

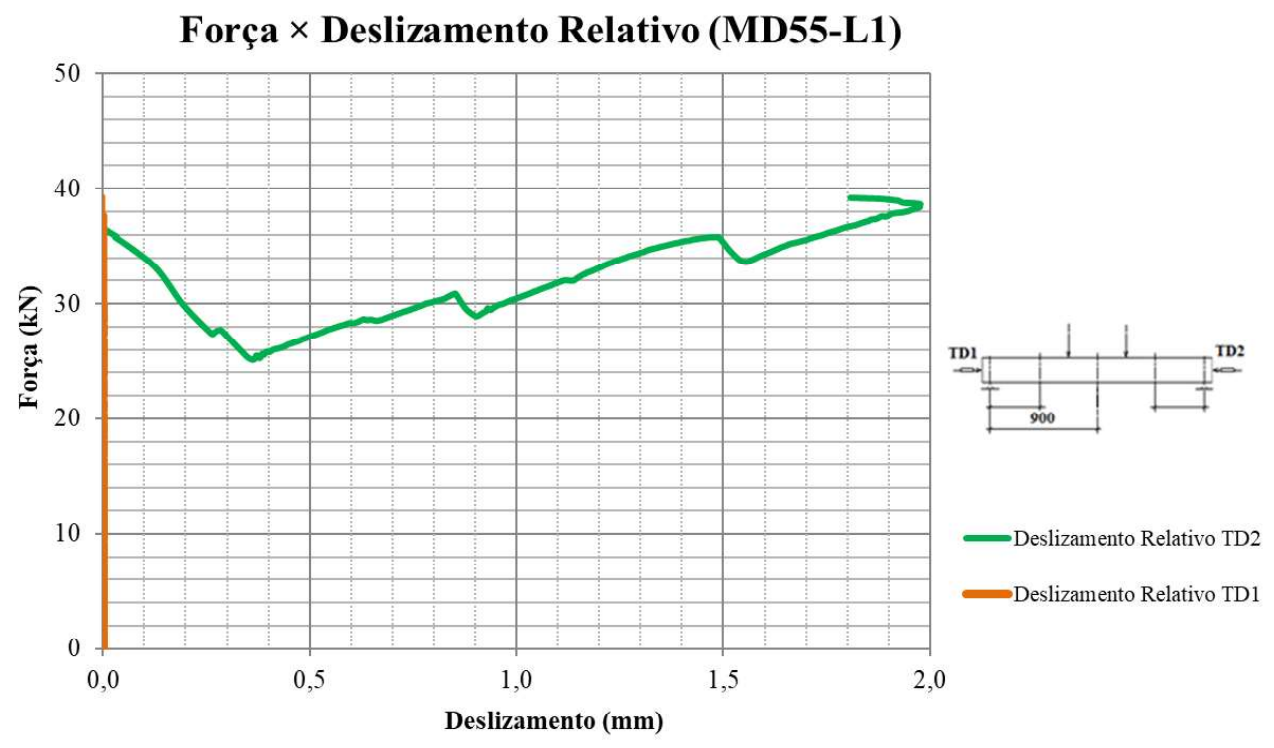

Fonte: Autora (2020) 
Figura C. 2. Curva Força x Flecha do protótipo MD55-L2.

\section{Força x Flecha (MD55-L1)}

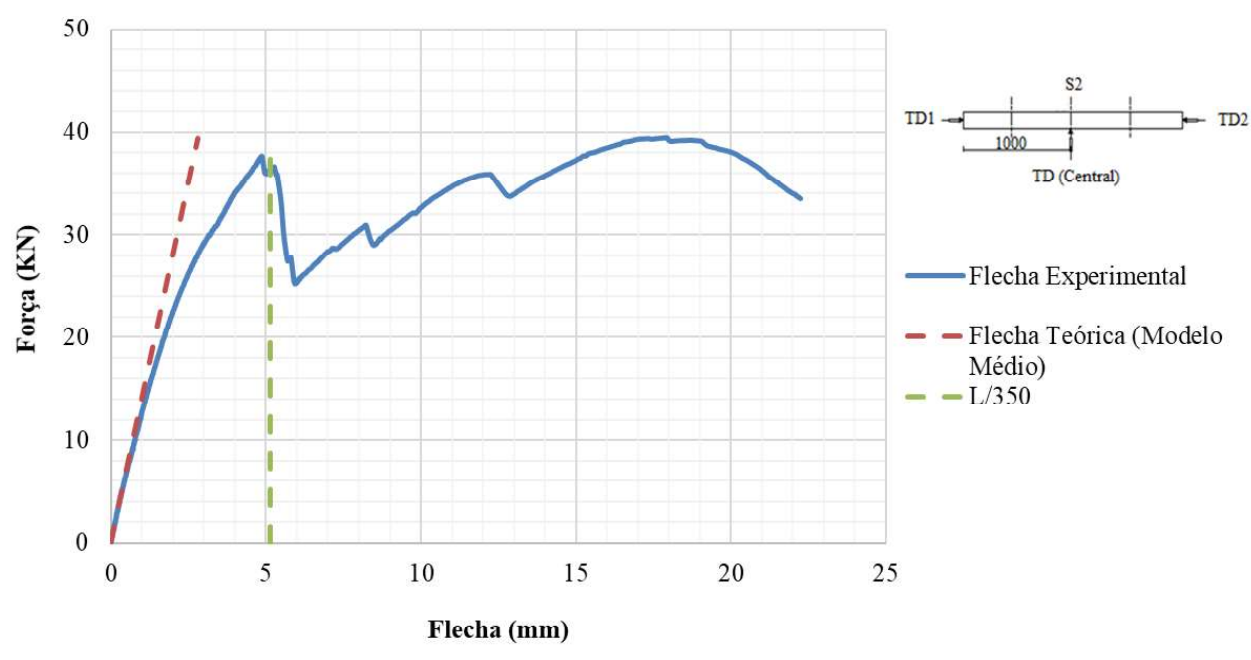

Fonte: Autora (2020)

Figura C. 3. Curvas Força x Deformação no concreto na seção S1 do protótipo MD55-L1.

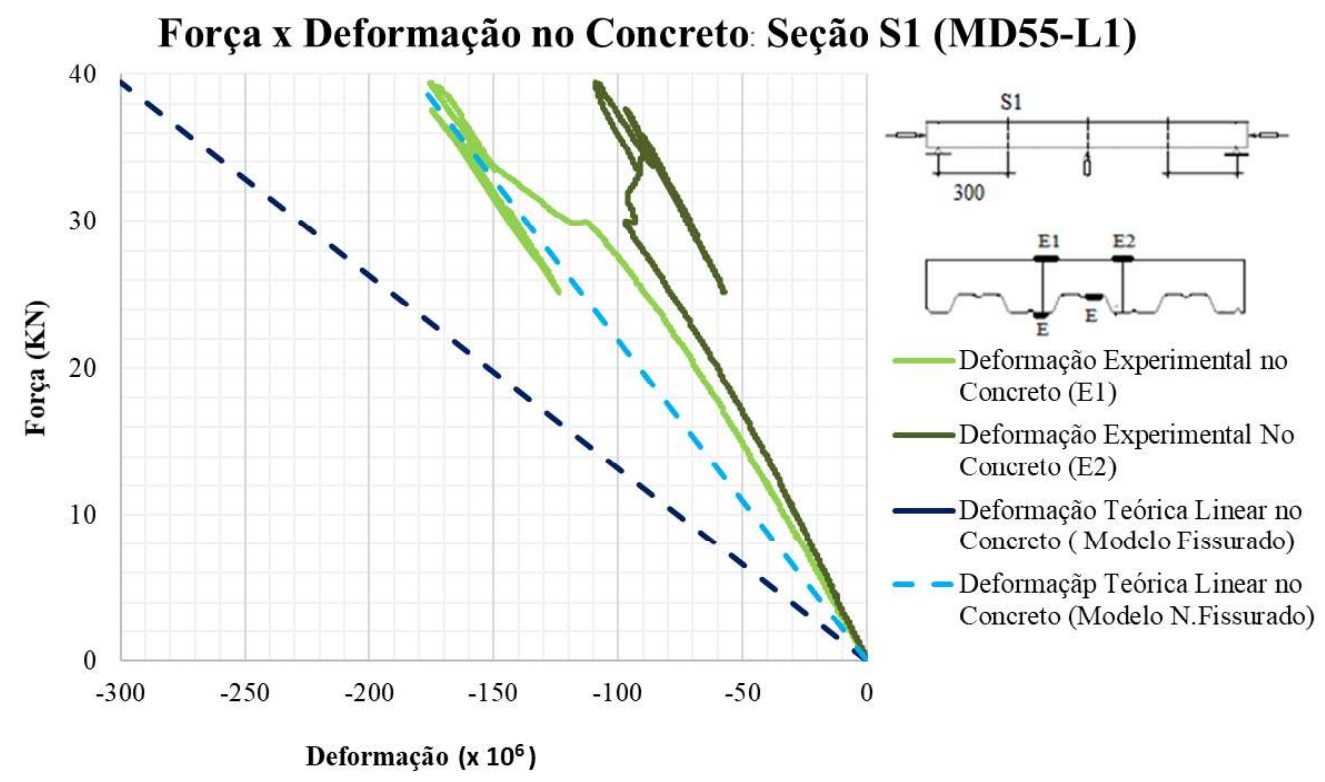

Fonte: Autora (2020) 
Figura C. 4. Curvas Força x Deformação no concreto na seção S2 do protótipo MD55-L1.

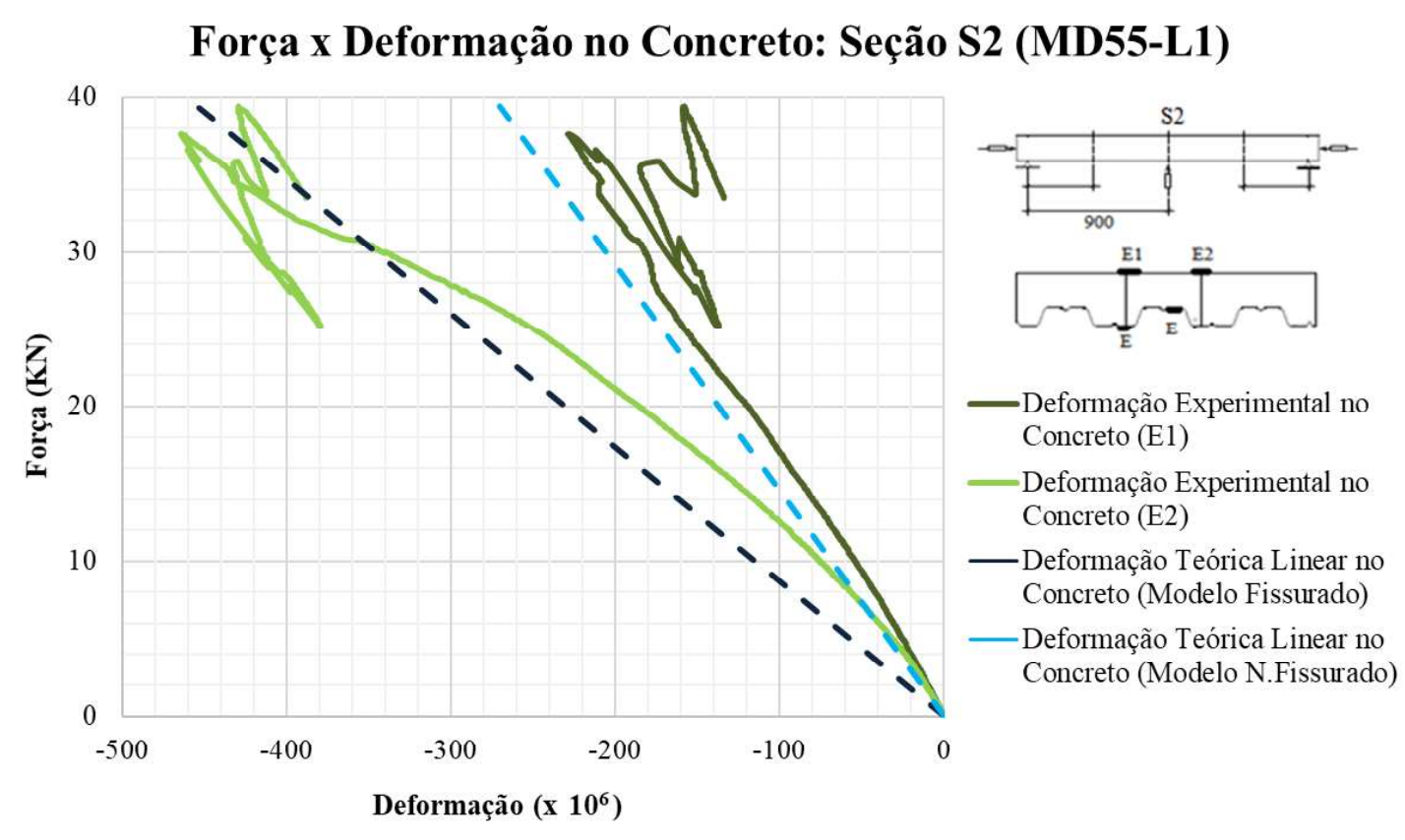

Fonte: Autora (2020)

Figura C. 5. Curvas Força x Deformação no concreto na seção S3 do protótipo MD55-L1.

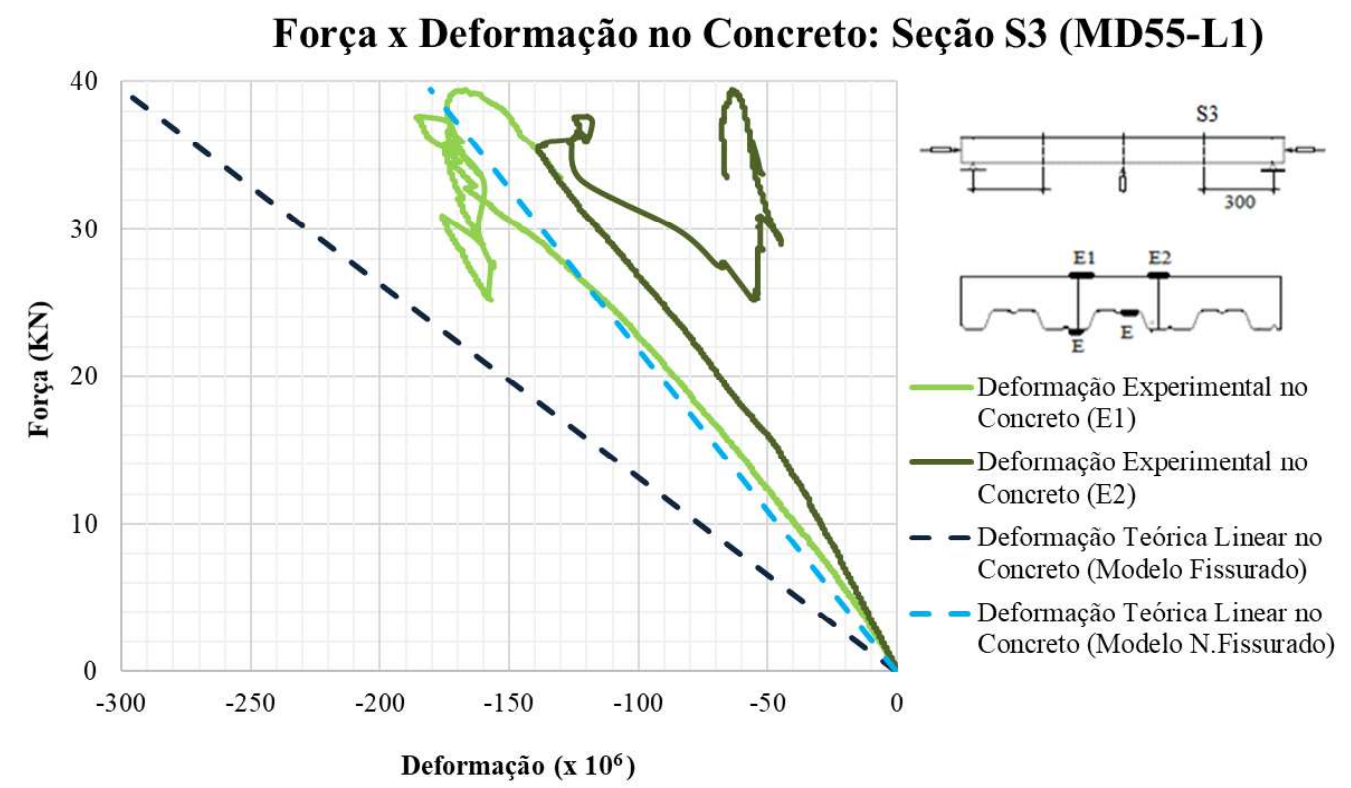

Fonte: Autora (2020) 
Figura C. 6. Curvas Força x Deformação na fôrma de aço naa seção S1 do protótipo MD55-L1.

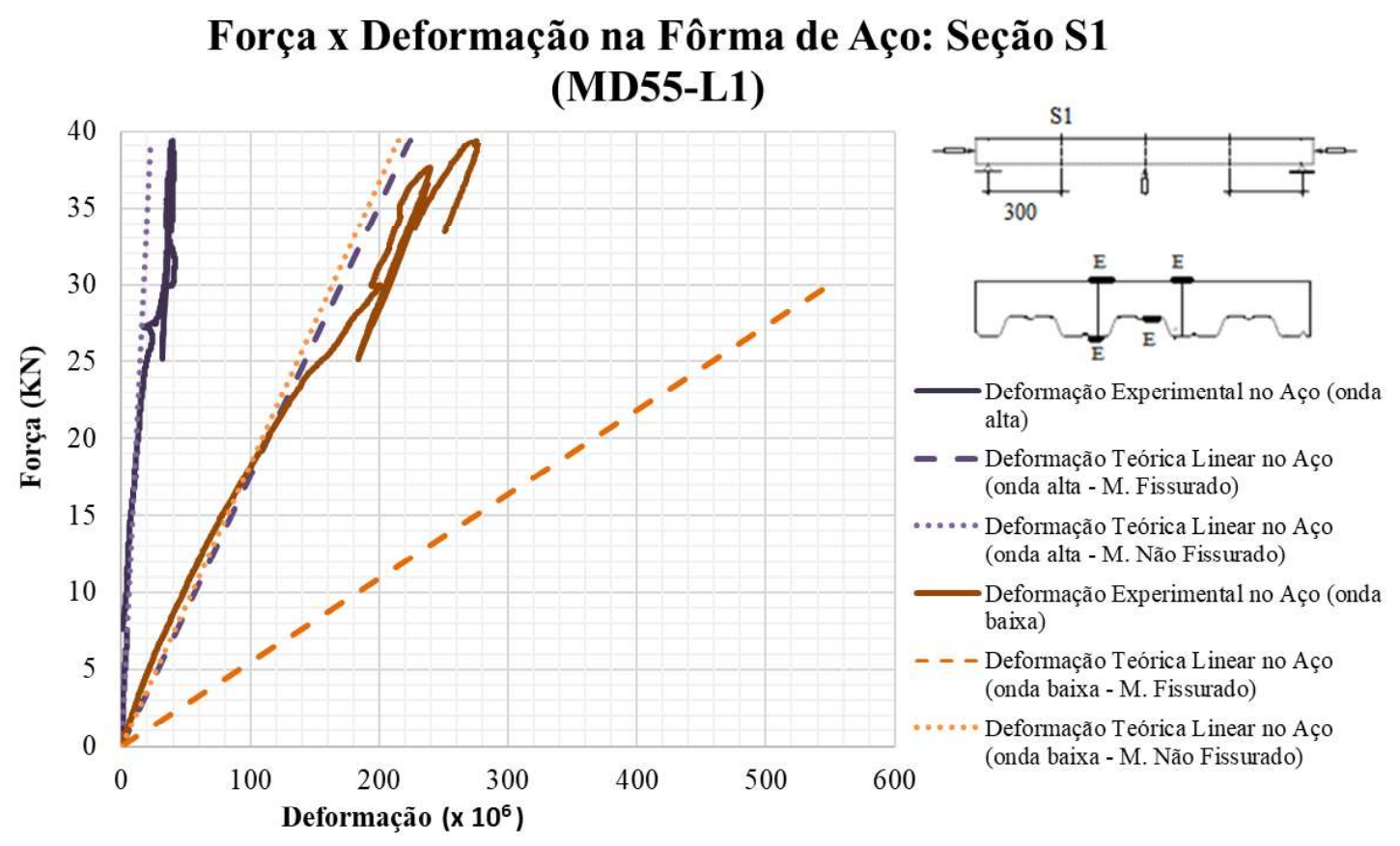

Fonte: Autora (2020)

Figura C. 7. Curvas Força x deformação na fôrma de aço na seção S2 do protótipo MD55-L1.

\section{Força x Deformação na Fôrma de Aço: Seção S2}

(MD55-L1)
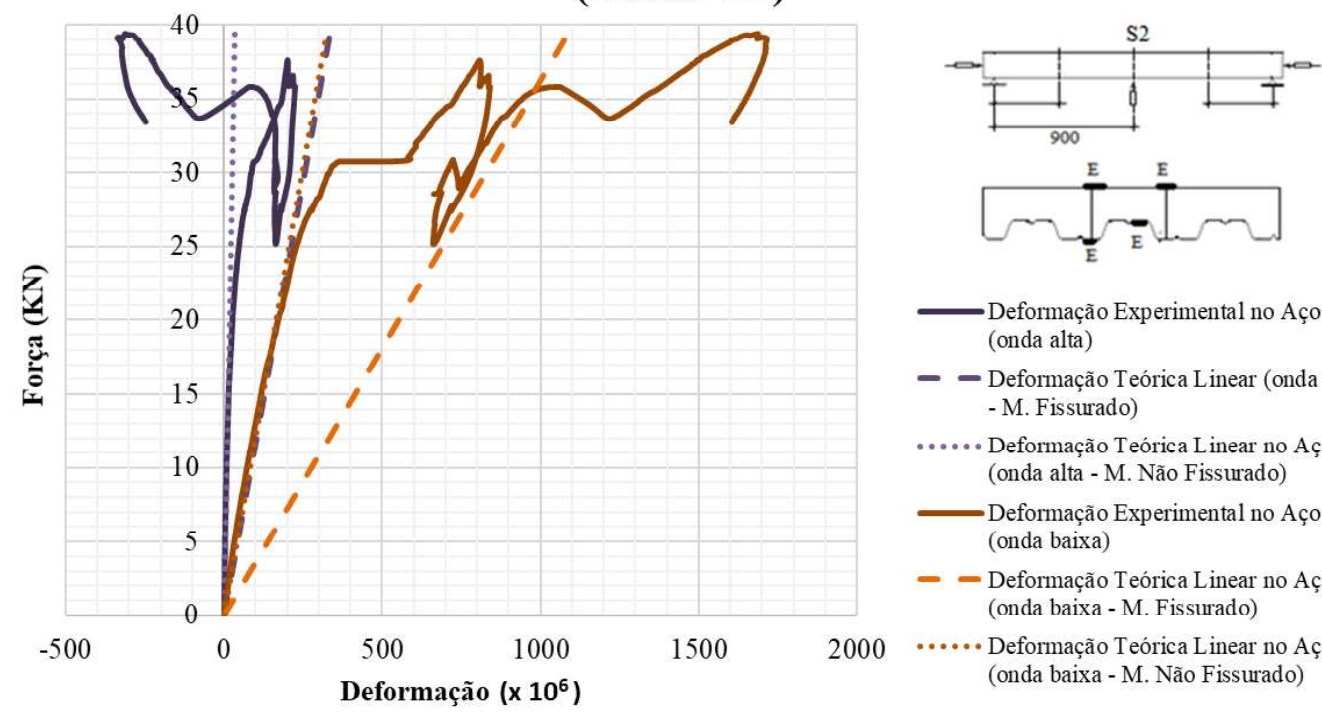

——Deformação Experimental no Aço (onda alta)

- Deformação Teórica Linear (onda alta - M. Fissurado)

..... Deformação Teórica Linear no Aço (onda alta - M. Não Fissurado)

Deformação Experimental no Aço (onda baixa)

- Deformação Teórica Linear no Aço (onda baixa - M. Fissurado)

... Deformação Teórica Linear no Aço (onda baixa - M. Não Fissurado)

Fonte: Autora (2020) 
Figura C. 8. Curvas Força x Deformação na fôrma de aço na seção S3 do protótipo MD55-L1.

\section{Força x Deformação na Fôrma de Aço: Seção S3}

(MD55-L1)

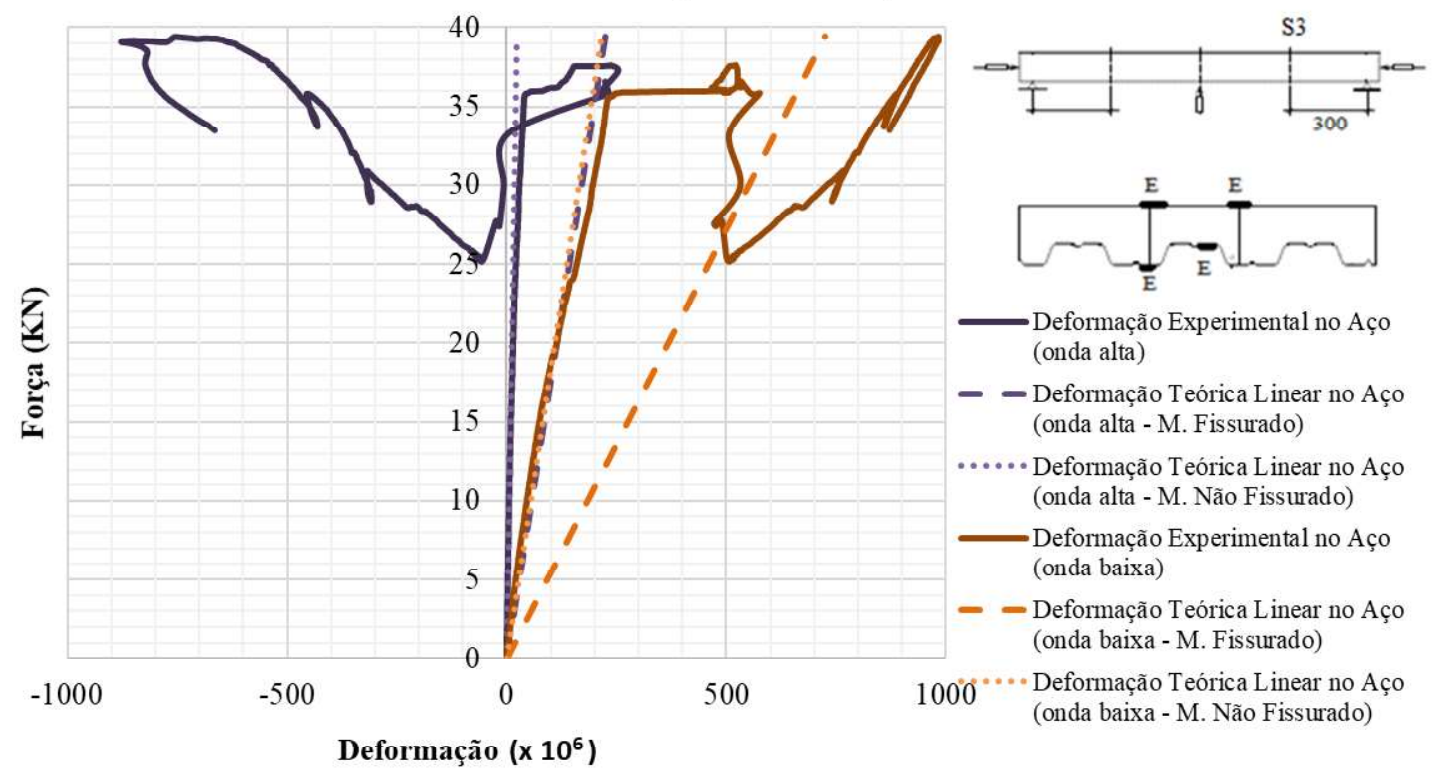

Fonte: Autora (2020) 


\section{C.2 CURVAS DO PROTÓTIPO MD55-L2}

Figura C. 9. Curva Força x Deslizamento relativo do protótipo MD55-L2.

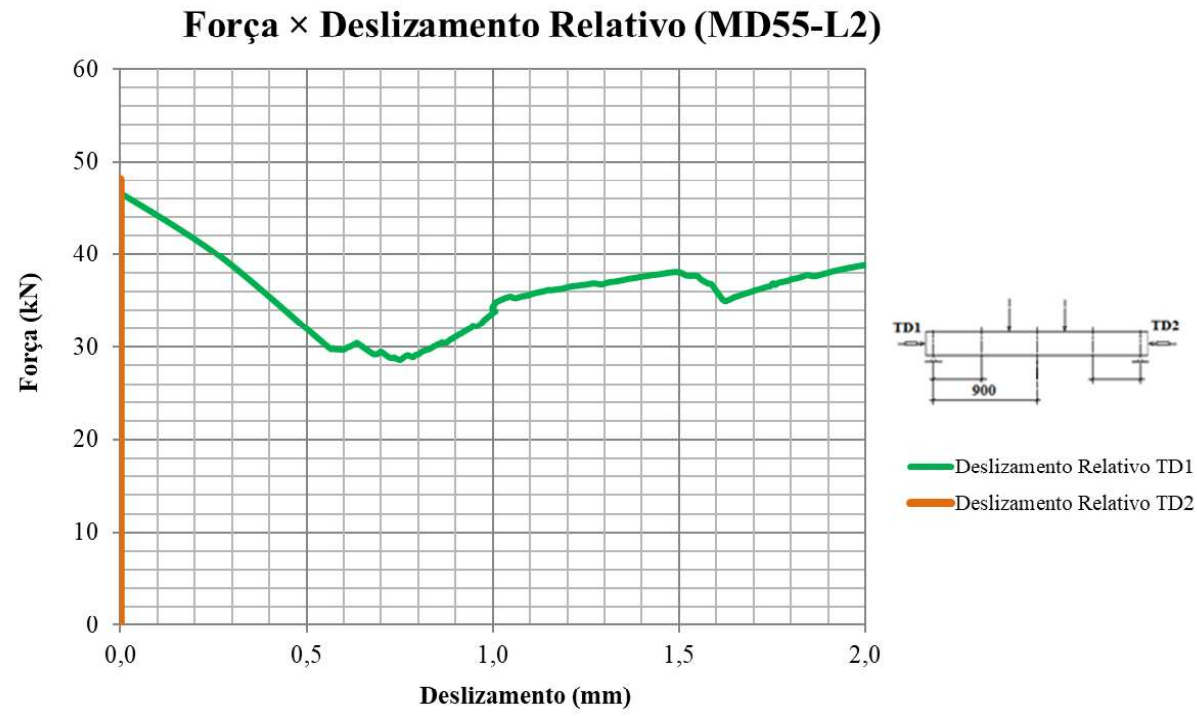

Fonte: Autora (2020)

Figura C. 10. Curva Força x Flecha do protótipo MD55-L2.

\section{Força x Flecha (MD55-L2)}

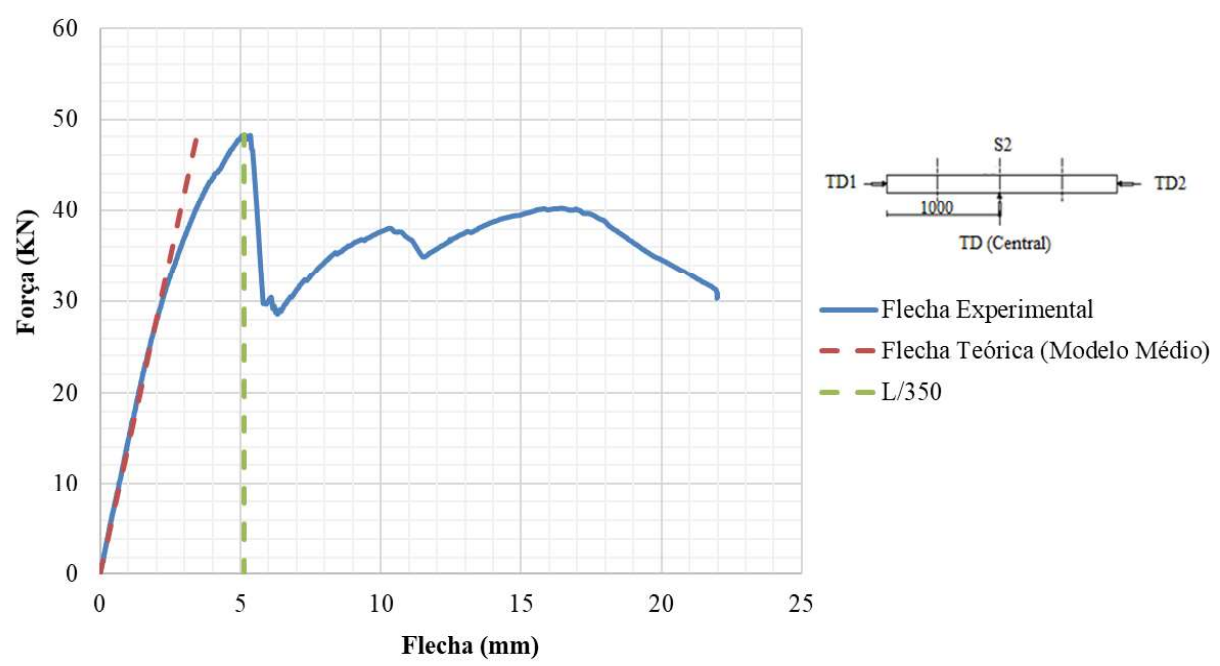

Fonte: Autora (2020) 


\section{C.3 CURVAS DO PROTÓTIPO MD55-L3}

Figura C. 11. Curva Força x Deslizamento relativo do protótipo MD55-L3.

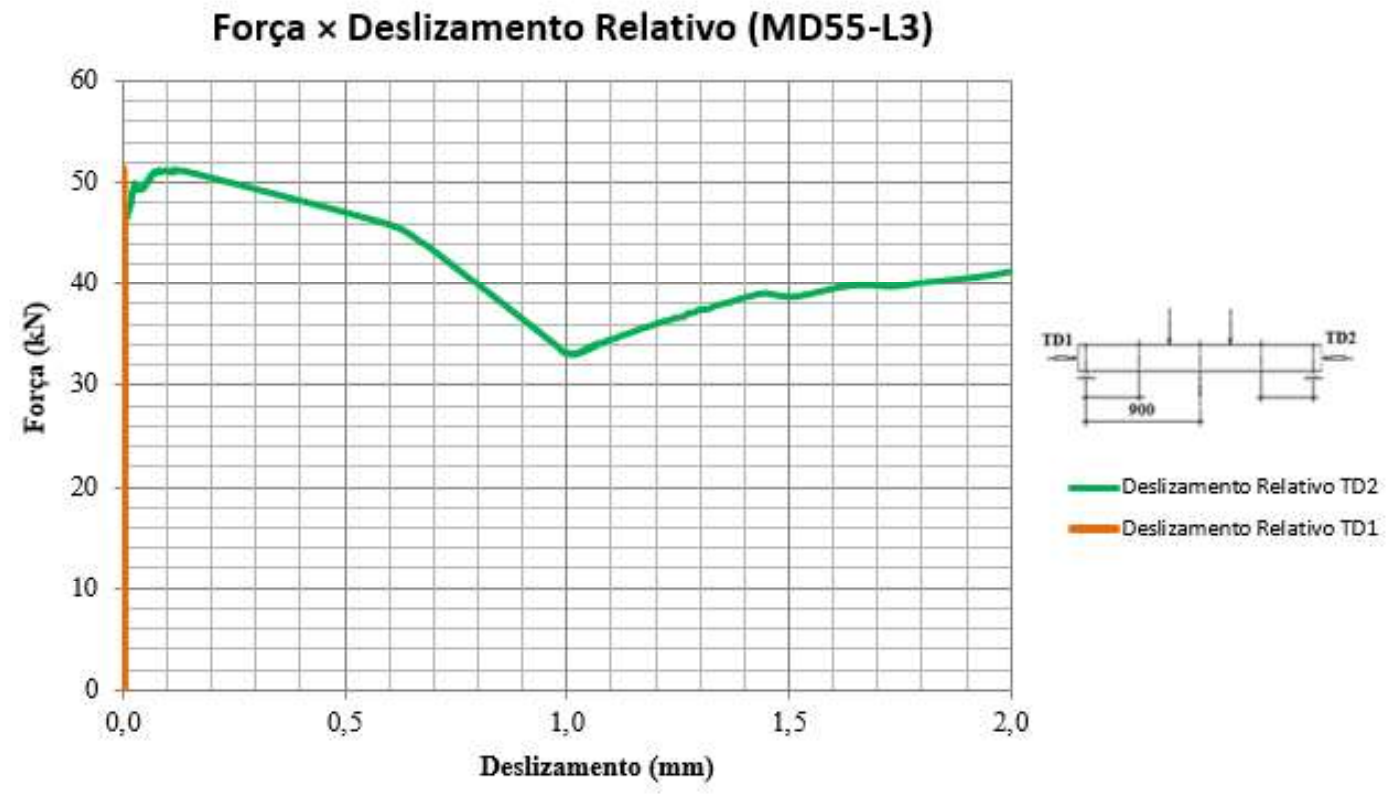

Fonte: Autora (2020)

Figura C. 12. Curva Força x Flecha do protótipo MD55-L3.

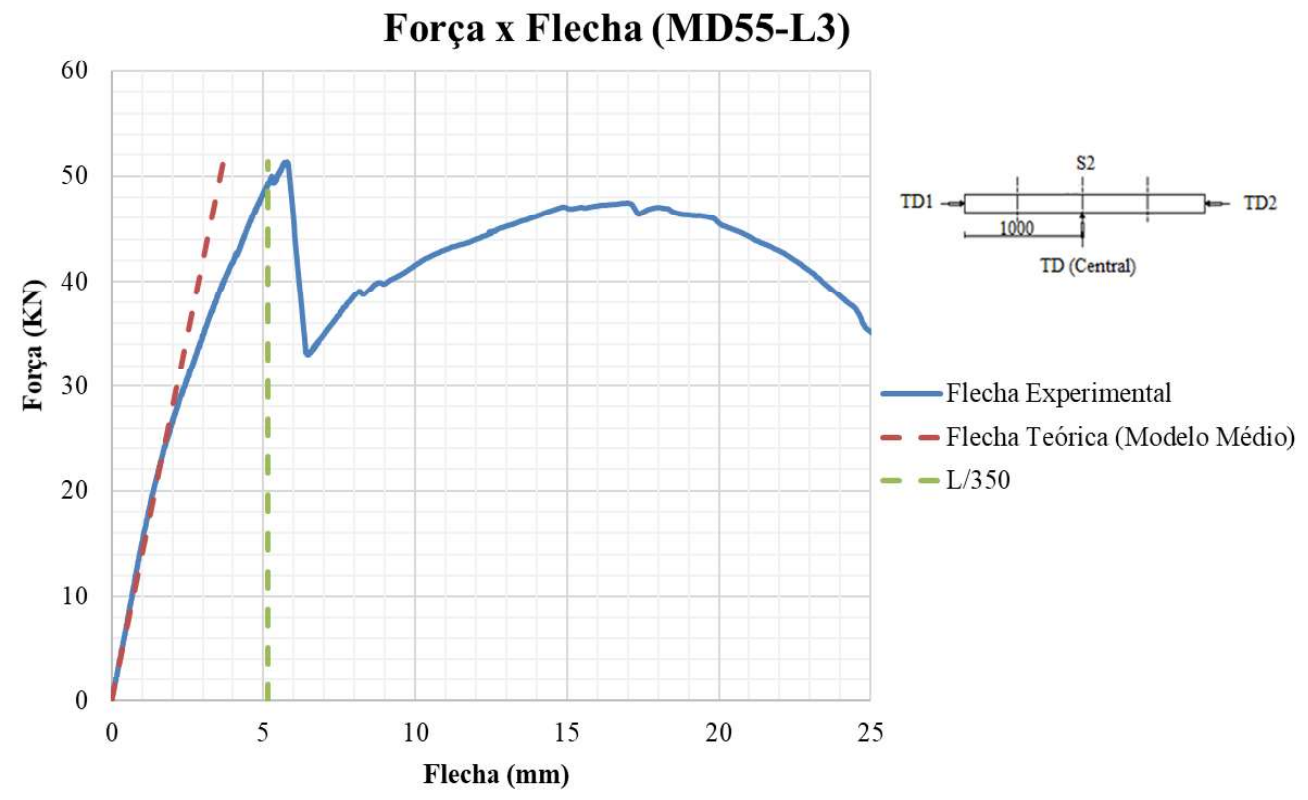

Fonte: Autora (2020) 


\section{C.4 CURVAS DO PROTÓTIPO MD55-L4}

Figura C. 13. Curva Força x Flecha do protótipo MD55-L4.

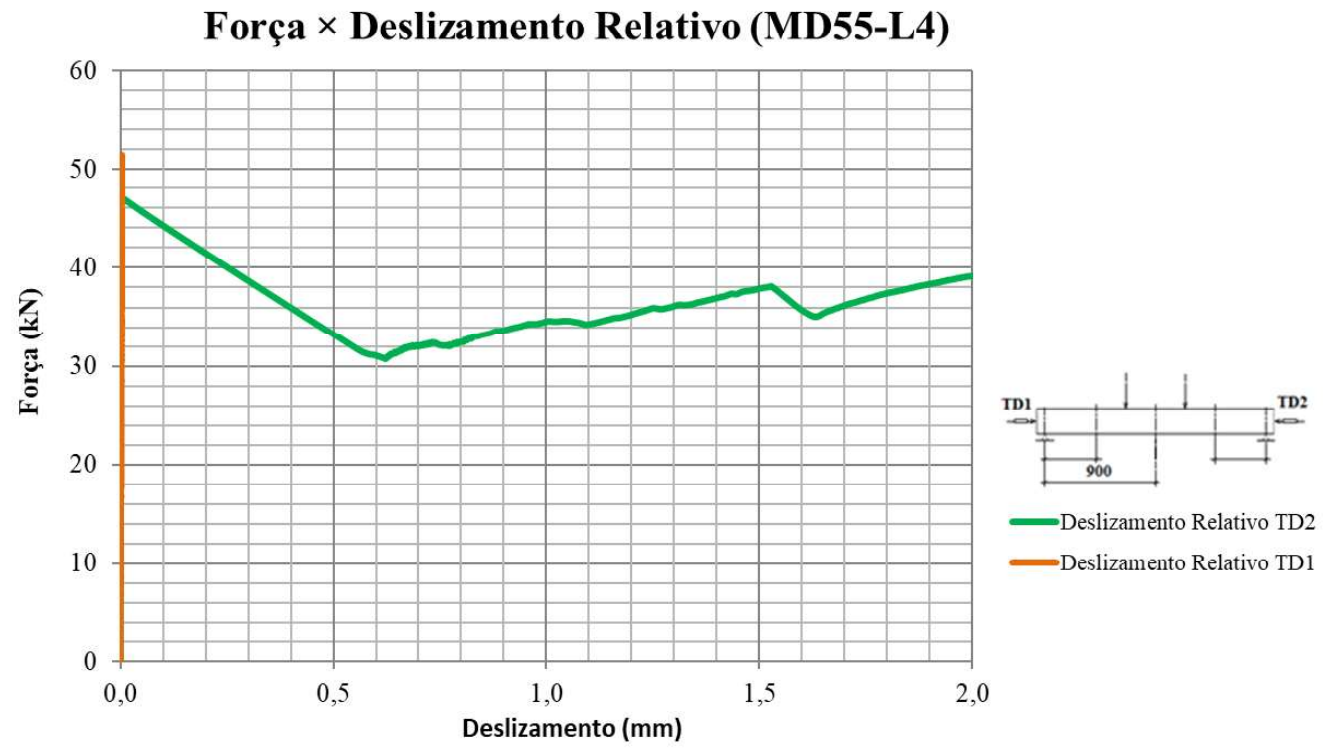

Fonte: Autora (2020)

Figura C. 14. Curva Força x Flecha do protótipo MD55-L4.

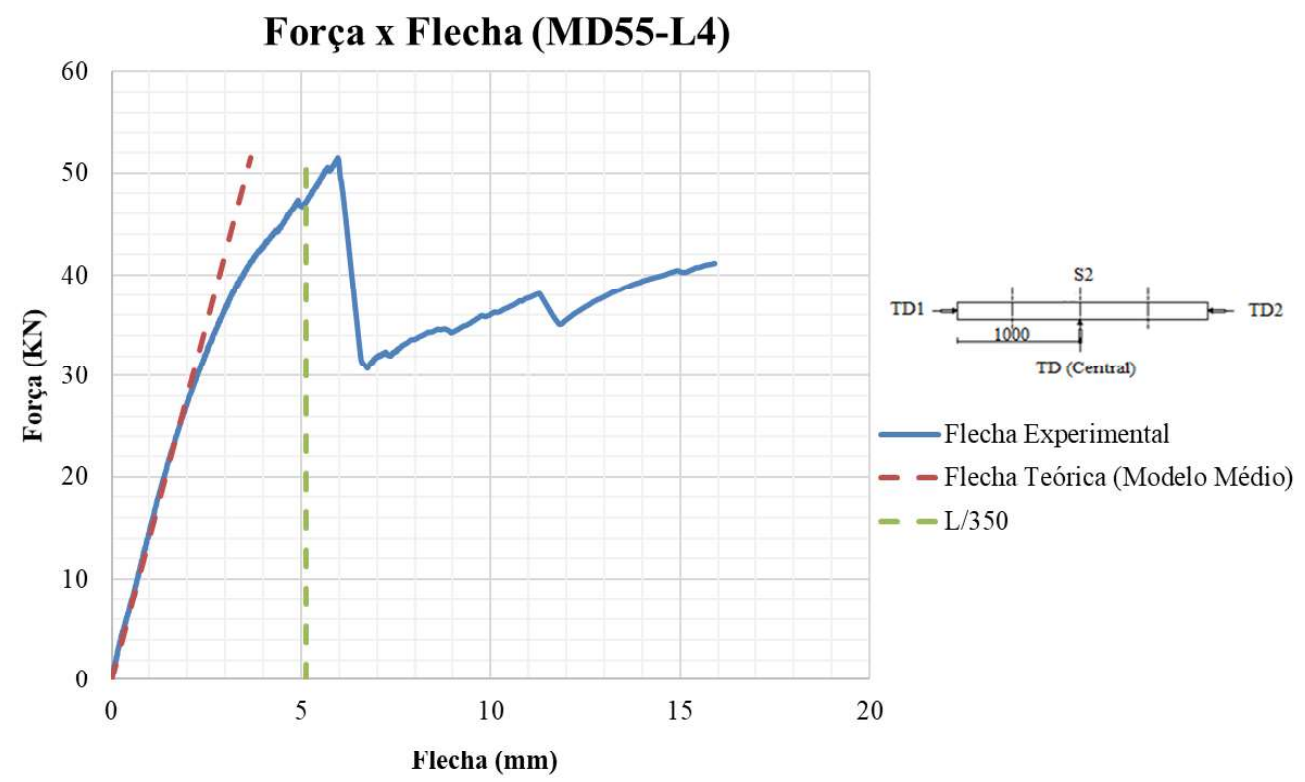

Fonte: Autora (2020) 


\section{C.5 CURVAS DO PROTÓTIPO MD55-L5}

Figura C. 15. Curva Força x Deslizamento relativo do protótipo MD55-L5.

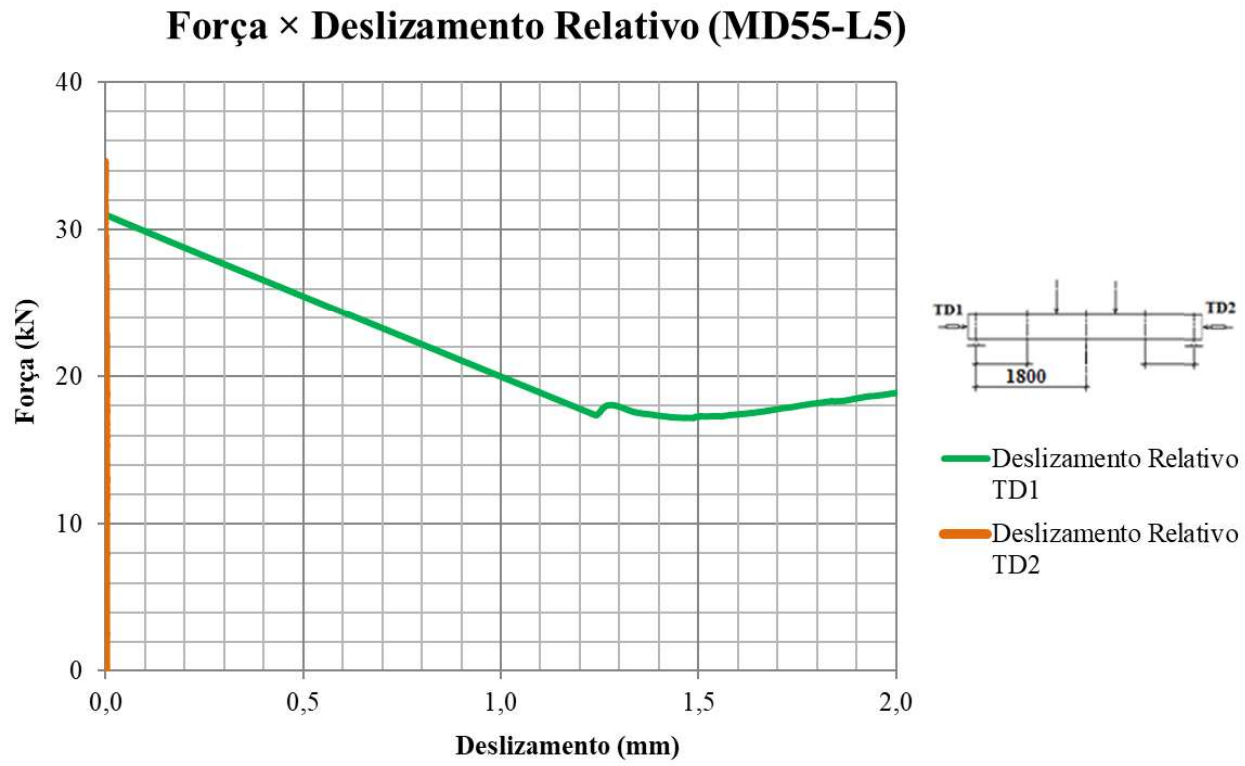

Fonte: Autora (2020)

Figura C. 16. Curva Força x Flecha do protótipo MD55-L5.

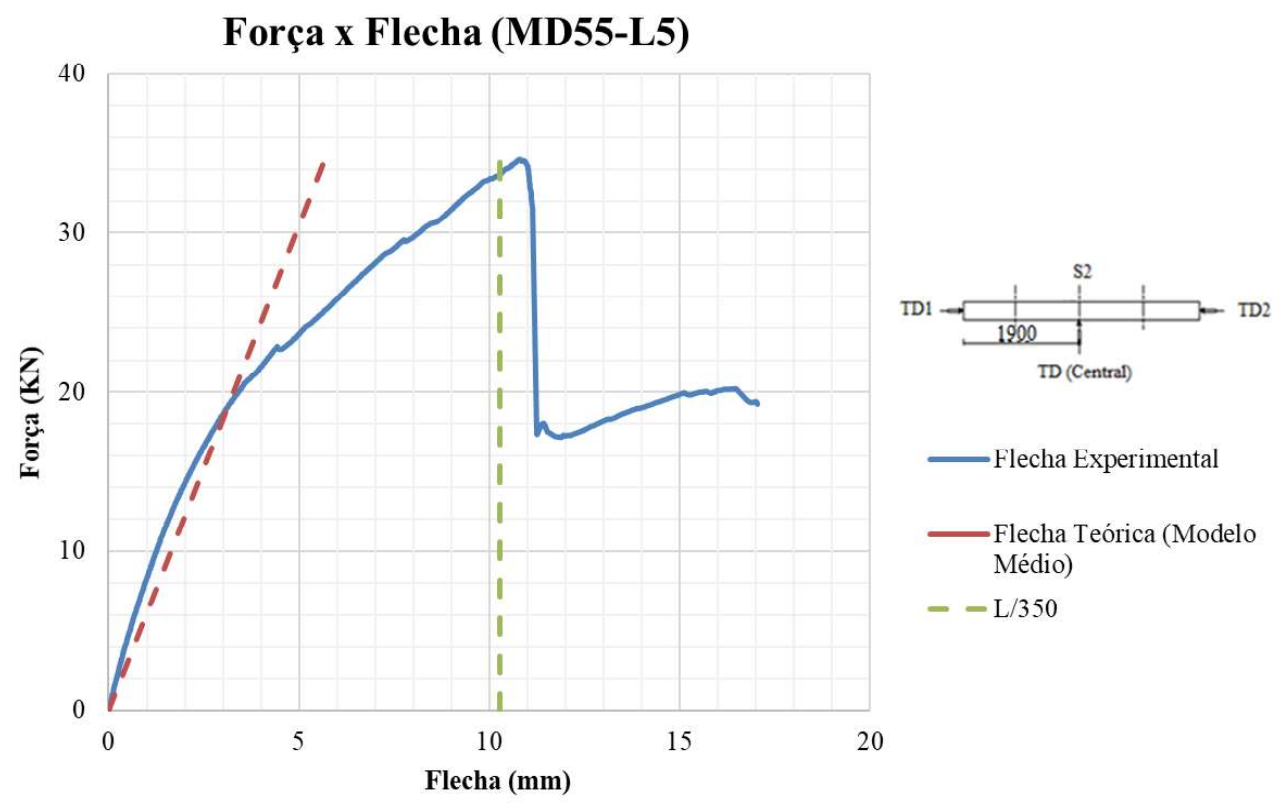

Fonte: Autora (2020) 
Figura C. 17. Curvas Força x Deformação no concreto na seção S1 do protótipo MD55-L5.

Força x Deformação no Concreto: Seção S1
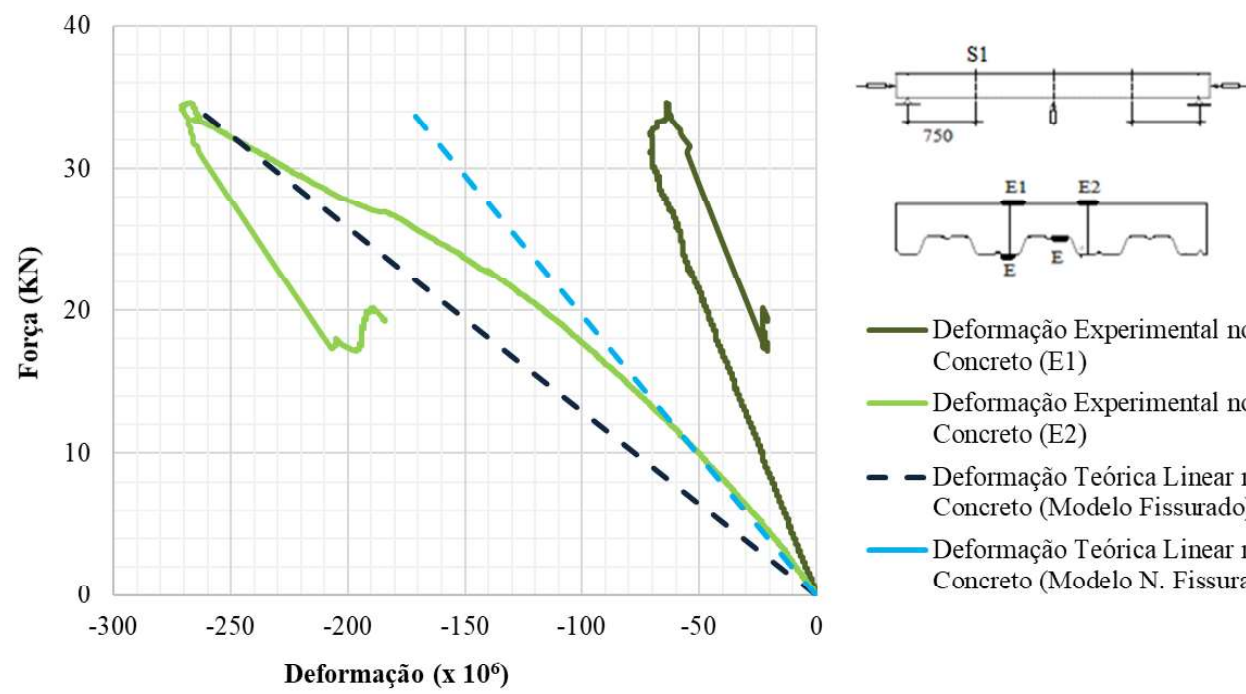

Deformação Experimental no Concreto (E1)

-Deformação Experimental no Concreto (E2)

- - Deformação Teórica Linear no Concreto (Modelo Fissurado)

—Deformação Teórica Linear no Concreto (Modelo N. Fissurado)

Fonte: Autora (2020)

Figura C. 18. Curvas Força x Deformação no concreto na seção S2 do protótipo MD55-L5.

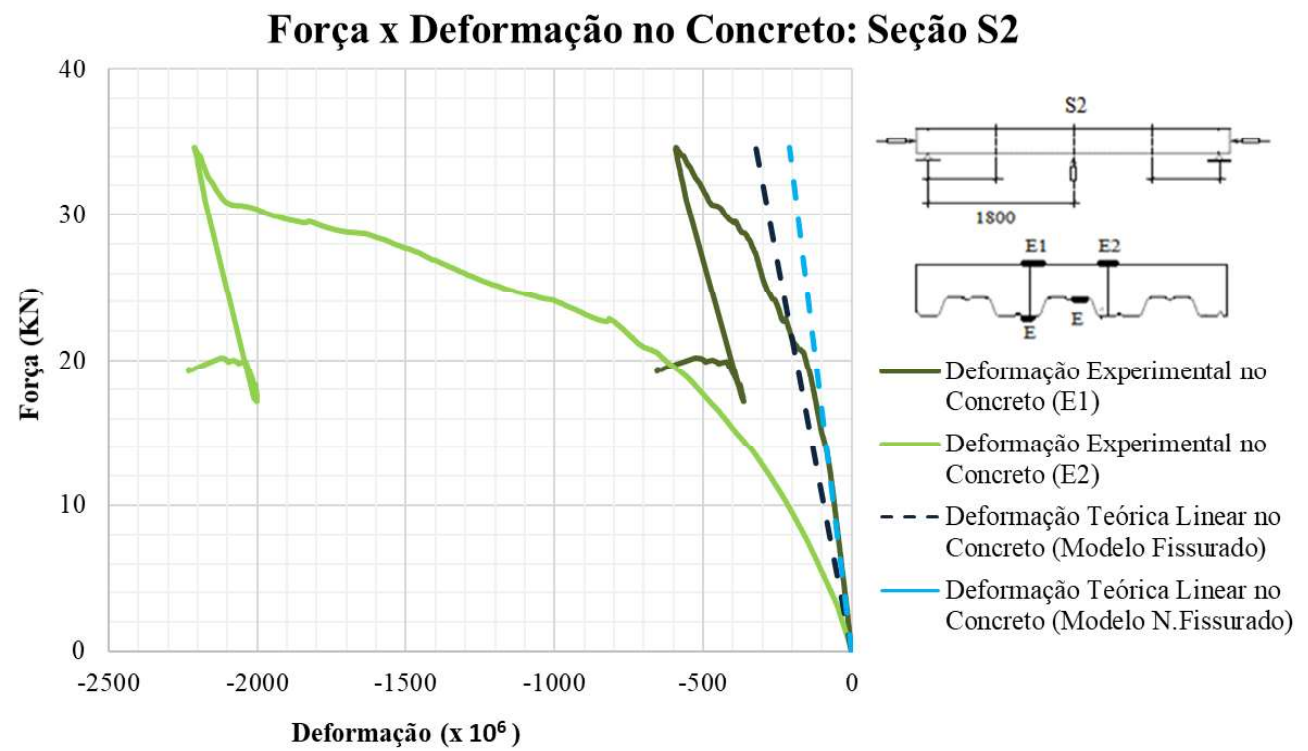

Fonte: Autora (2020) 
Figura C. 19. Curvas Força x Deformação no concreto na seção S3 do protótipo MD55-L5.

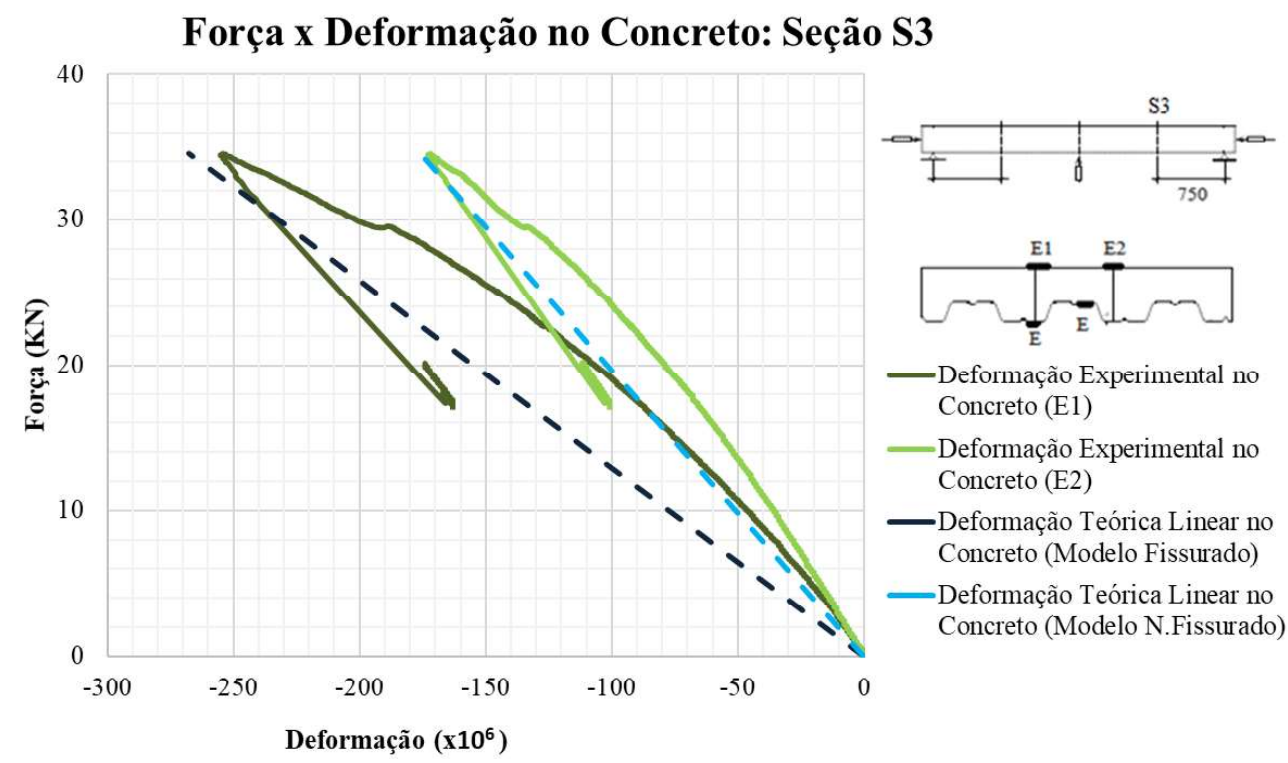

Fonte: Autora (2020)

Figura C. 20. Curvas Força x Deformação na fôrma de aço na seção S1 do protótipo MD55-L5.

\section{Força x Deformação na Fôrma de Aço: Seção S1}

(MD55-L5)
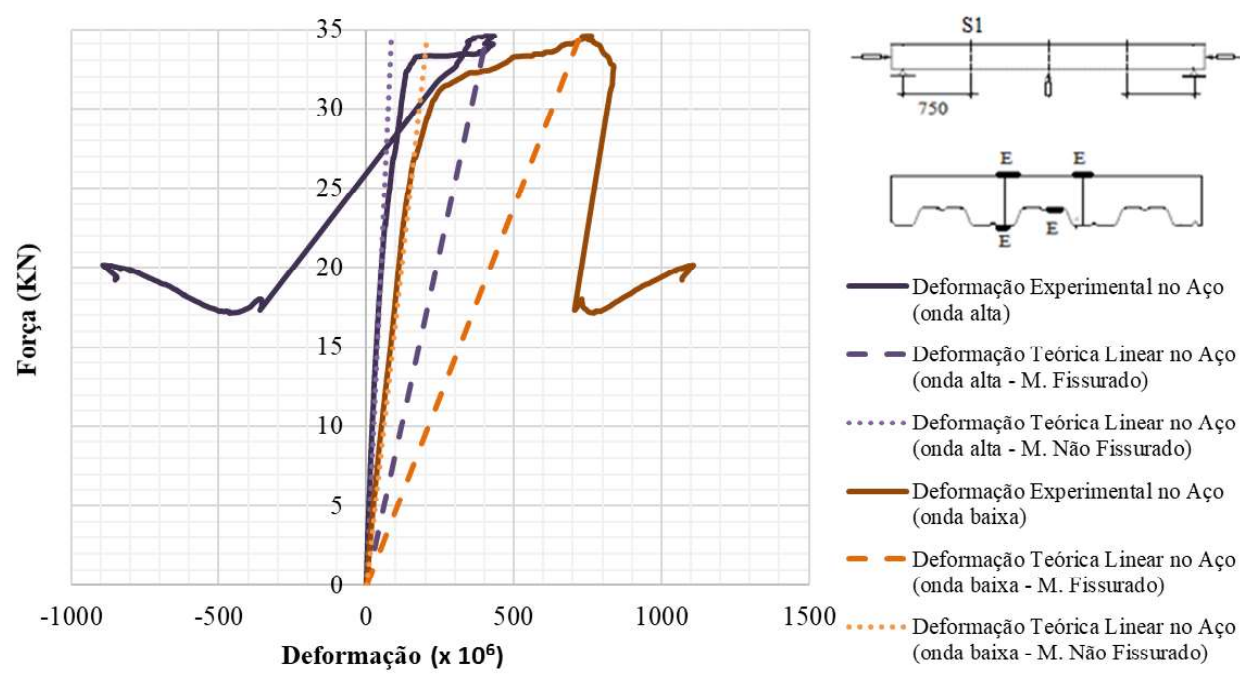

Deformação Experimental no Aço (onda alta)

- Deformação Teórica Linear no Aço (onda alta - M. Fissurado)

...... Deformação Teórica Linear no Aço (onda alta - M. Não Fissurado)

—Deformação Experimental no Aço (onda baixa)

- Deformação Teórica Linear no Aço (onda baixa - M. Fissurado)

- Deformação Teórica Linear no Aço (onda baixa - M. Não Fissurado)

Fonte: Autora (2020) 
Figura C. 21. Curvas Força x Deformação na fôrma de aço na seção S2 do protótipo MD55-L5.

\section{Força x Deformação na Fôrma de Aço: Seção S2}

(MD55-L5)
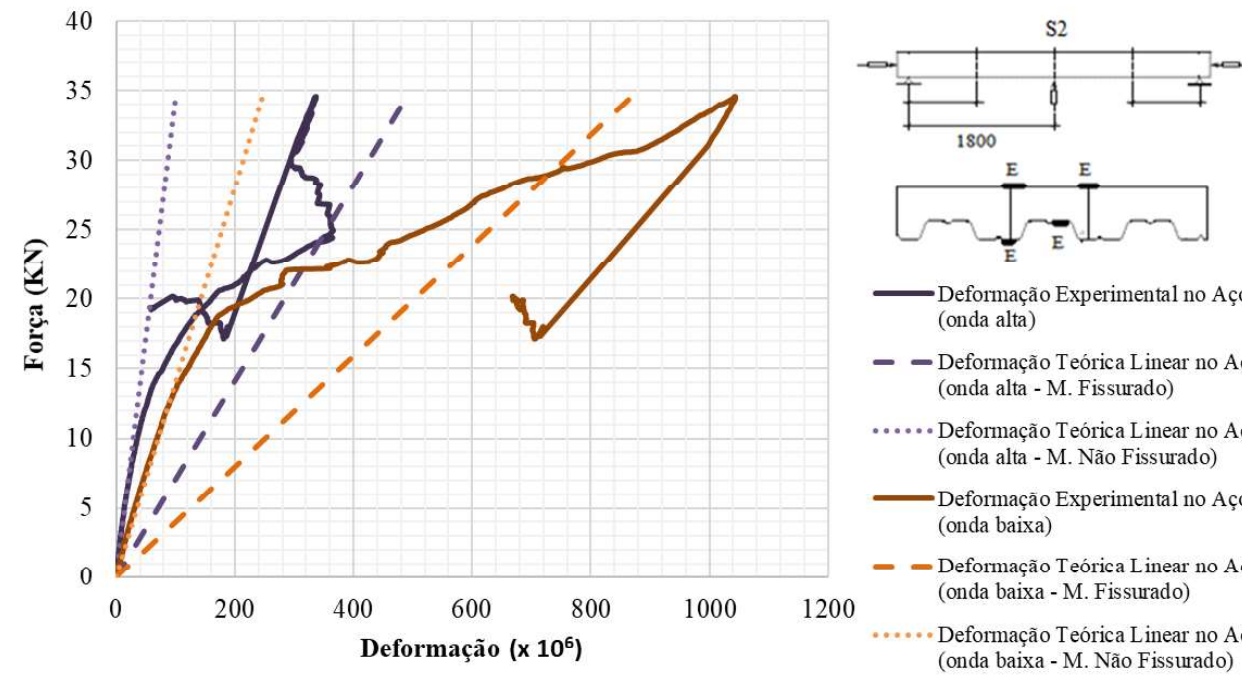

Deformação Experimental no Aço (onda alta)

- Deformação Teórica Linear no Aço (onda alta - M. Fissurado)

-..... Deformação Teórica Linear no Aço (onda alta - M. Não Fissurado)

—Deformação Experimental no Aço (onda baixa)

- Deformação Teórica Linear no Aço (onda baixa - M. Fissurado)

- Deformação Teórica Linear no Aço (onda baixa - M. Não Fissurado)

Fonte: Autora (2020)

Figura C. 22. Curvas Força x Deformação na fôrma de aço na seção S3 do protótipo MD55-L5.

\section{Força x Deformação na Fôrma de Aço: Seção S3}

(MD55-L5)
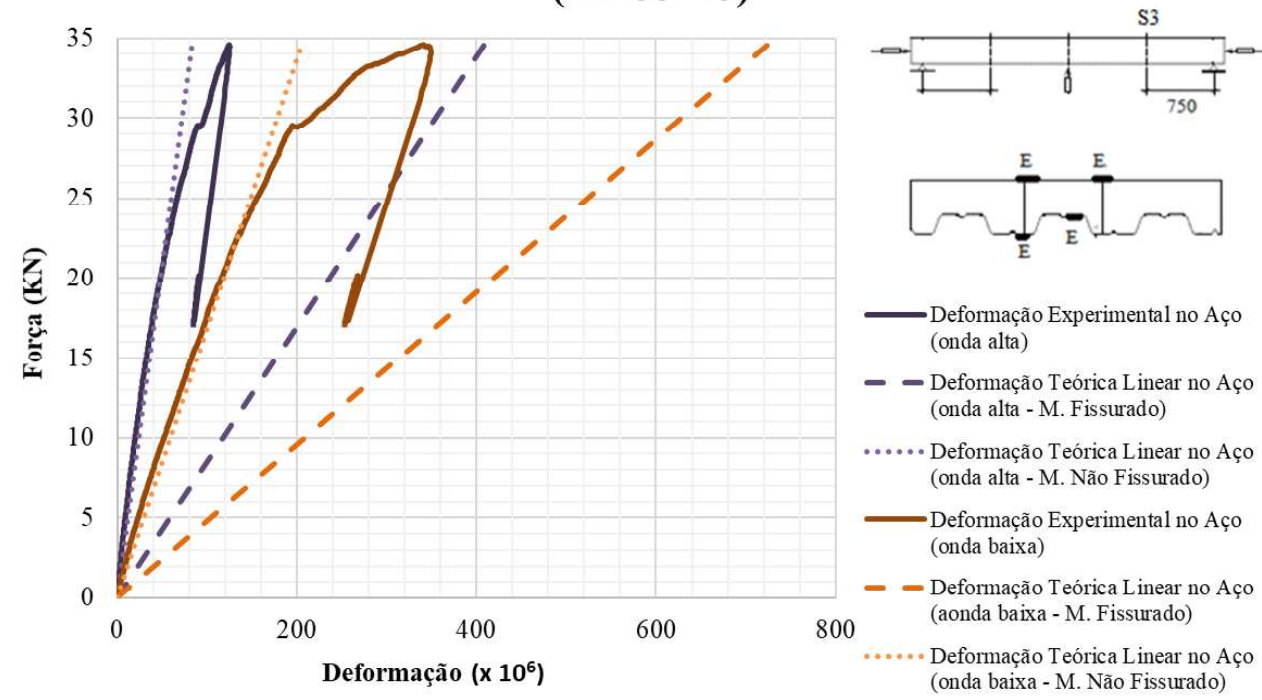

Fonte: Autora (2020) 
C.6 CURVAS DO PROTÓTIPO MD55-L6

Figura C. 23. Curva Força x Deslizamento Relativo do protótipo MD55-L6.

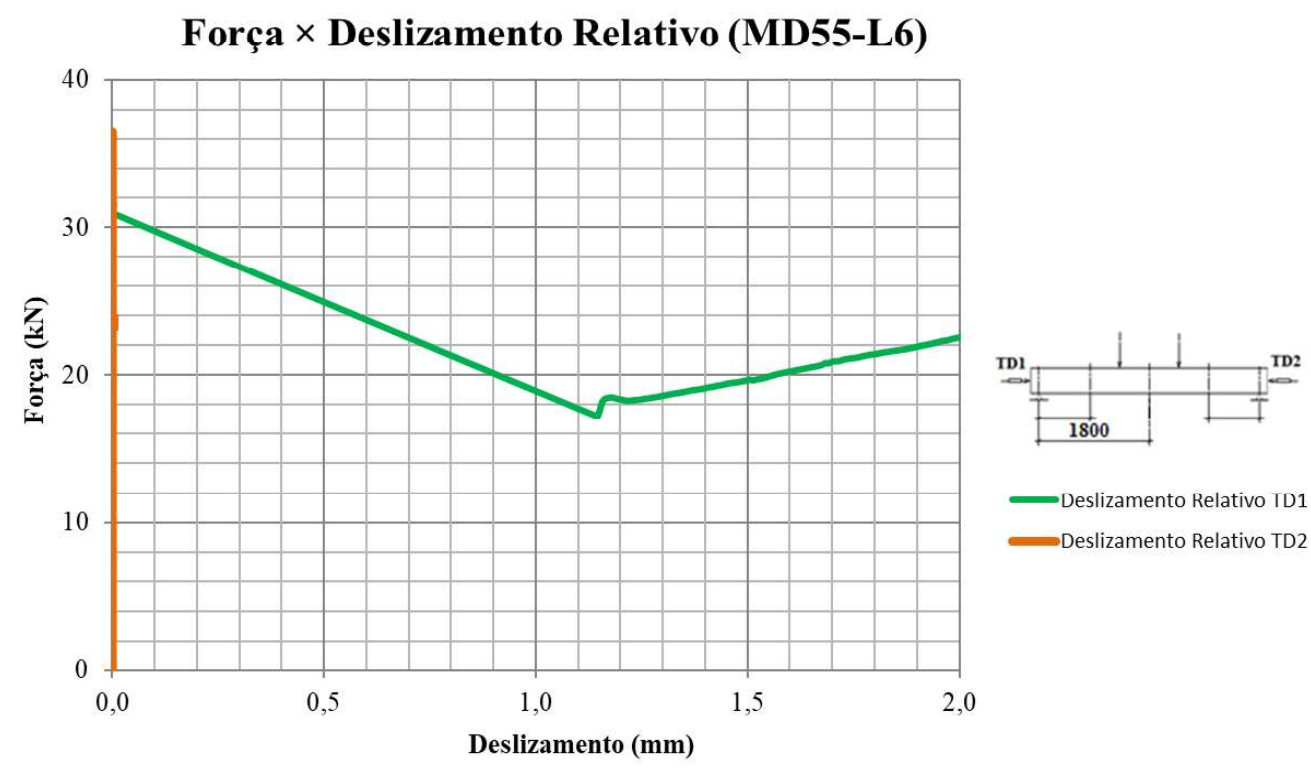

Fonte: Autora (2020)

Figura C. 24. Curva Força x Flecha do protótipo MD55-L6.

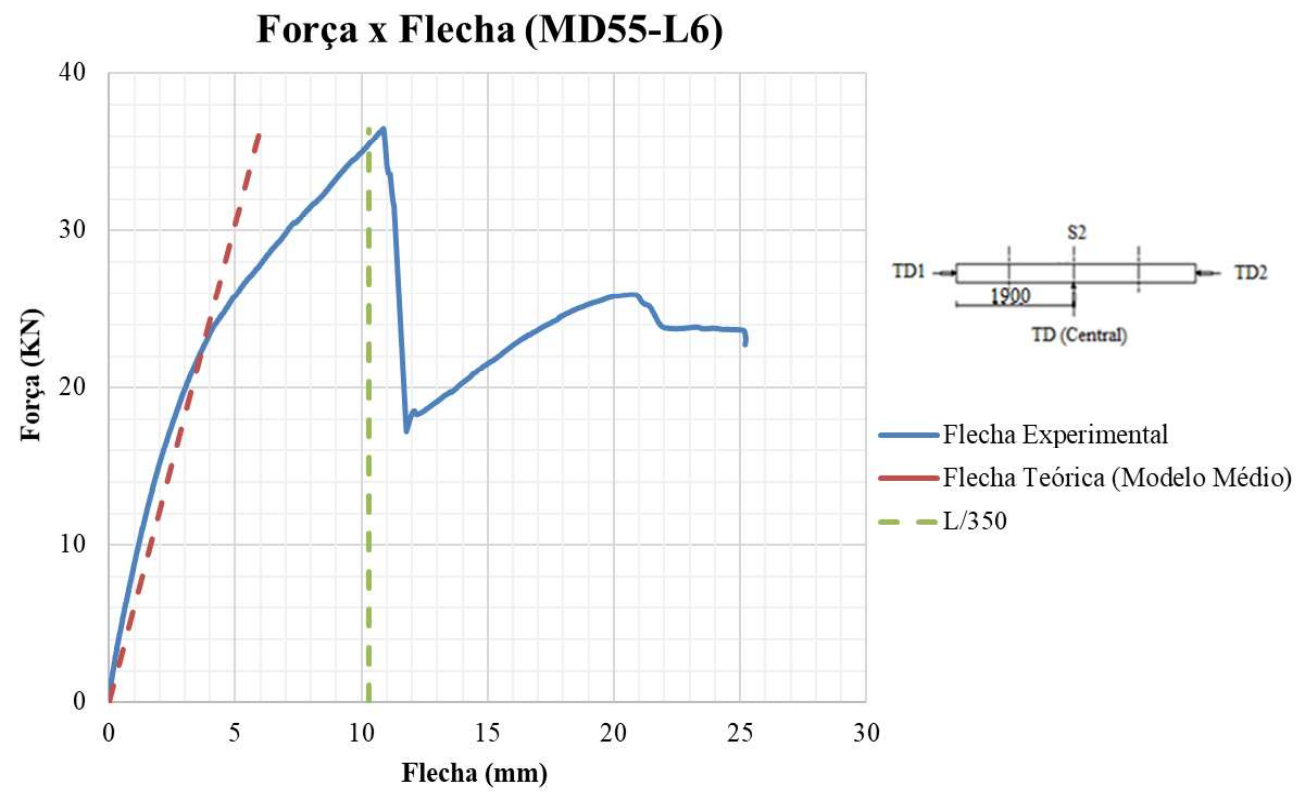

Fonte: Autora (2020) 
C.7 CURVAS DO PROTÓTIPO MD55-L7

Figura C. 25. Curva Força x Delizamento Relativo do protótipo MD55-L7.

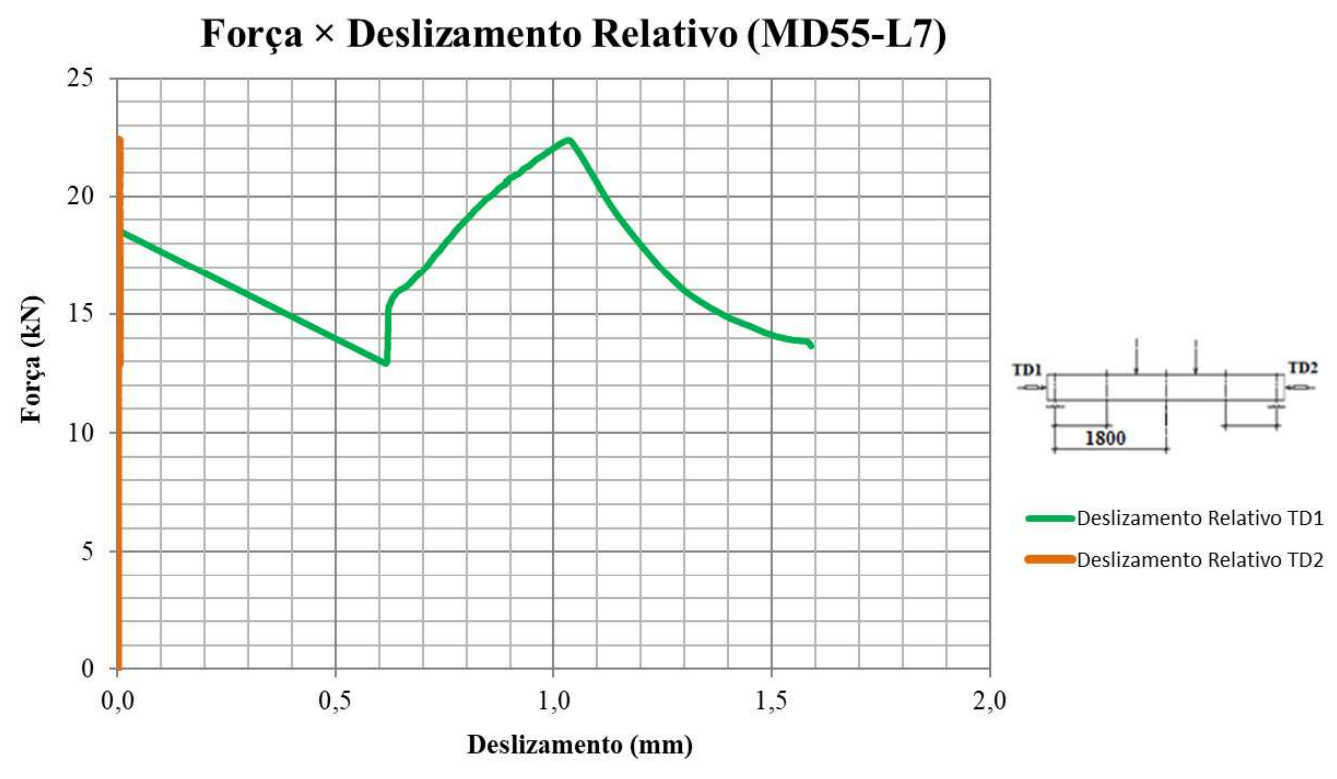

Fonte: Autora (2020)

Figura C. 26. Curva Força x Flecha do protótipo MD55-L7.

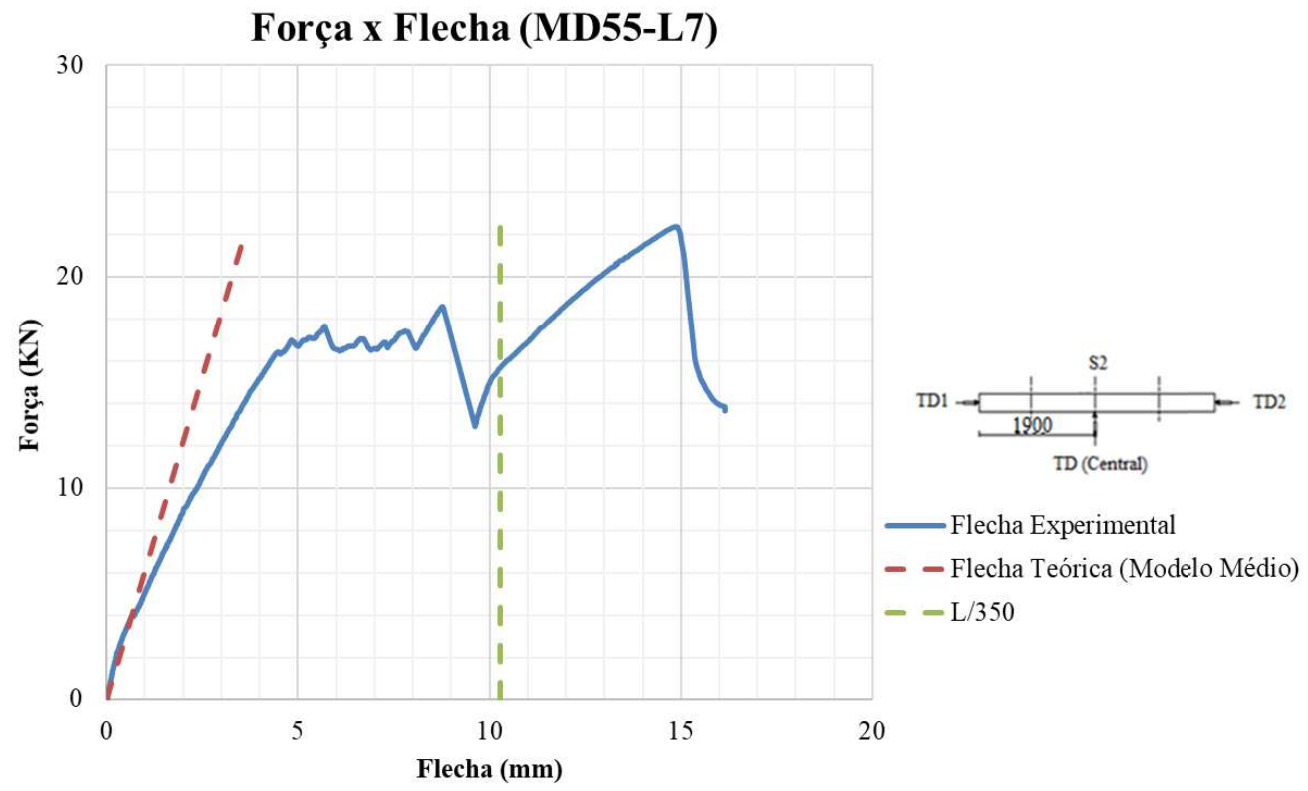

Fonte: Autora (2020) 


\section{C.8 CURVAS DO PROTÓTIPO MD55-L8}

Figura C. 27. Curva Força x Deslizamento Relativo do protótipo MD55-L8.

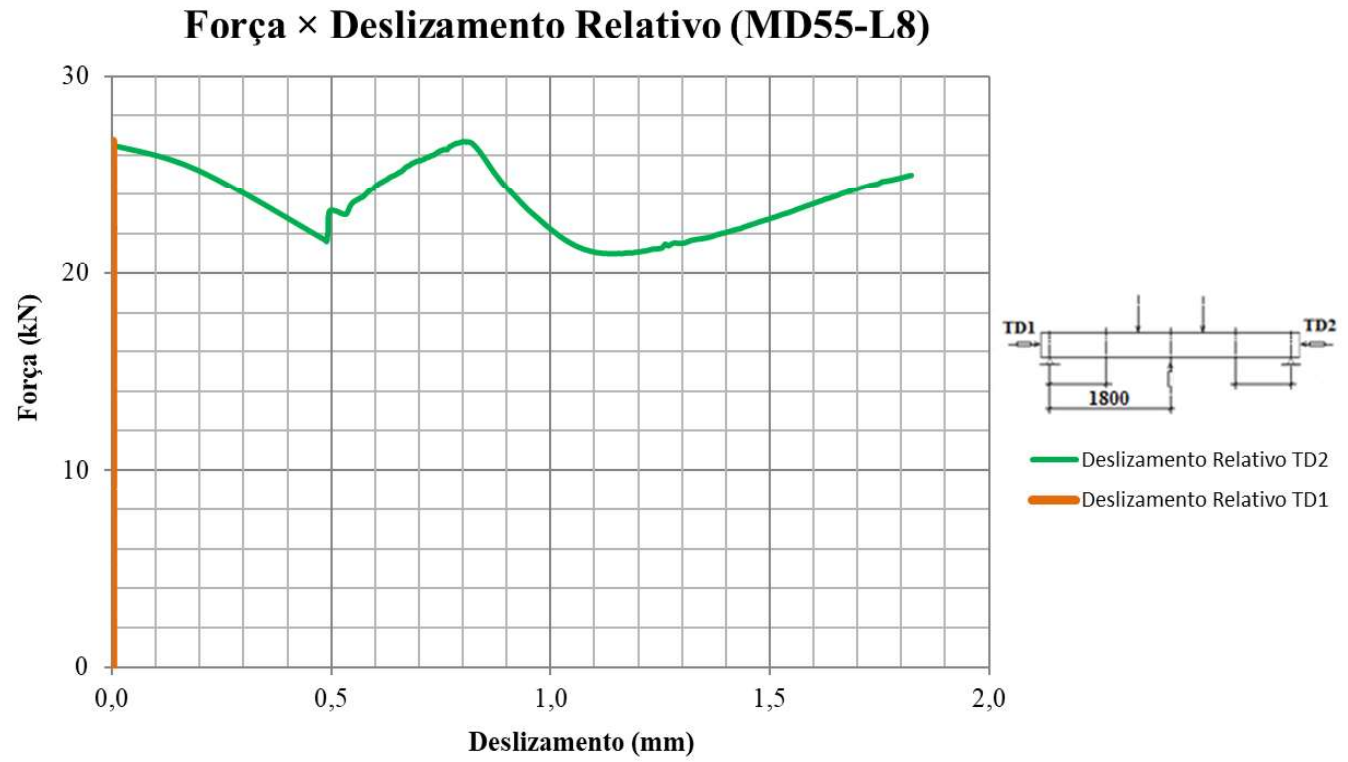

Fonte: Autora (2020)

Figura C. 28. Curva Força x Flecha do protótipo MD55-L8.

Força x Flecha (MD55-L8)

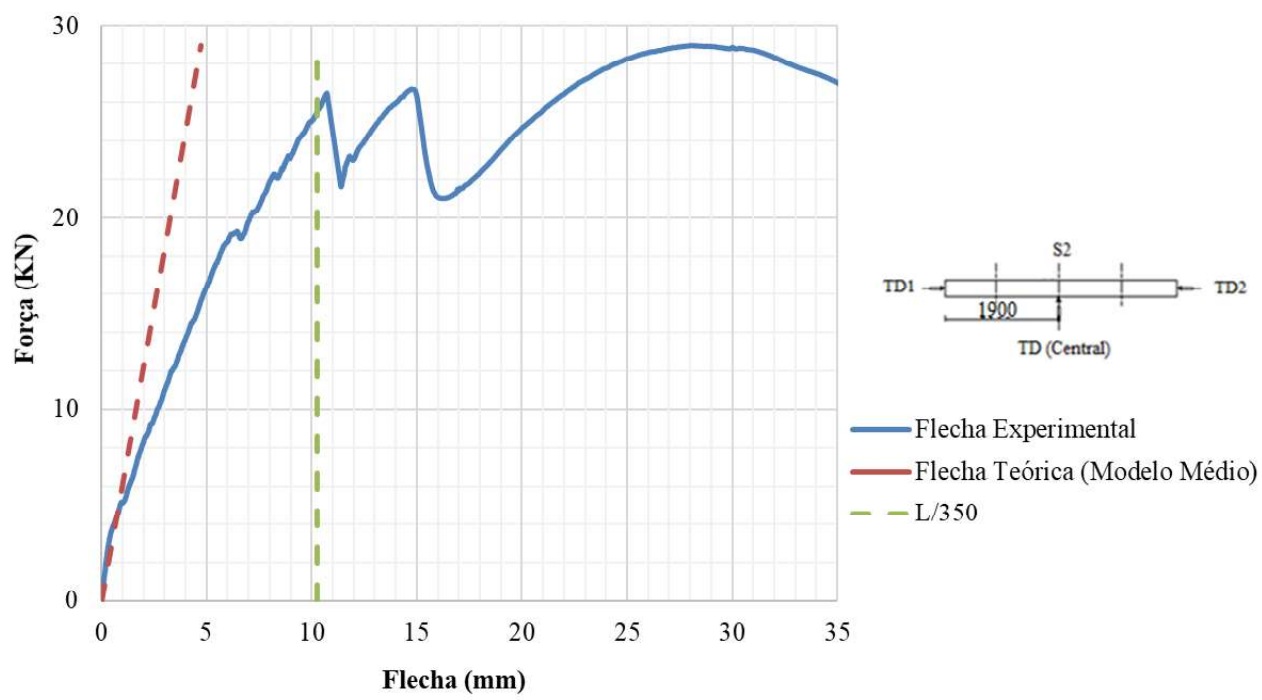

Fonte: Autora (2020) 


\section{C.9 CURVAS DO PROTÓTIPO MD55-LC1}

Figura C. 29. Curva Força x Deslizamento Relativo do protótipo MD55-LC1.

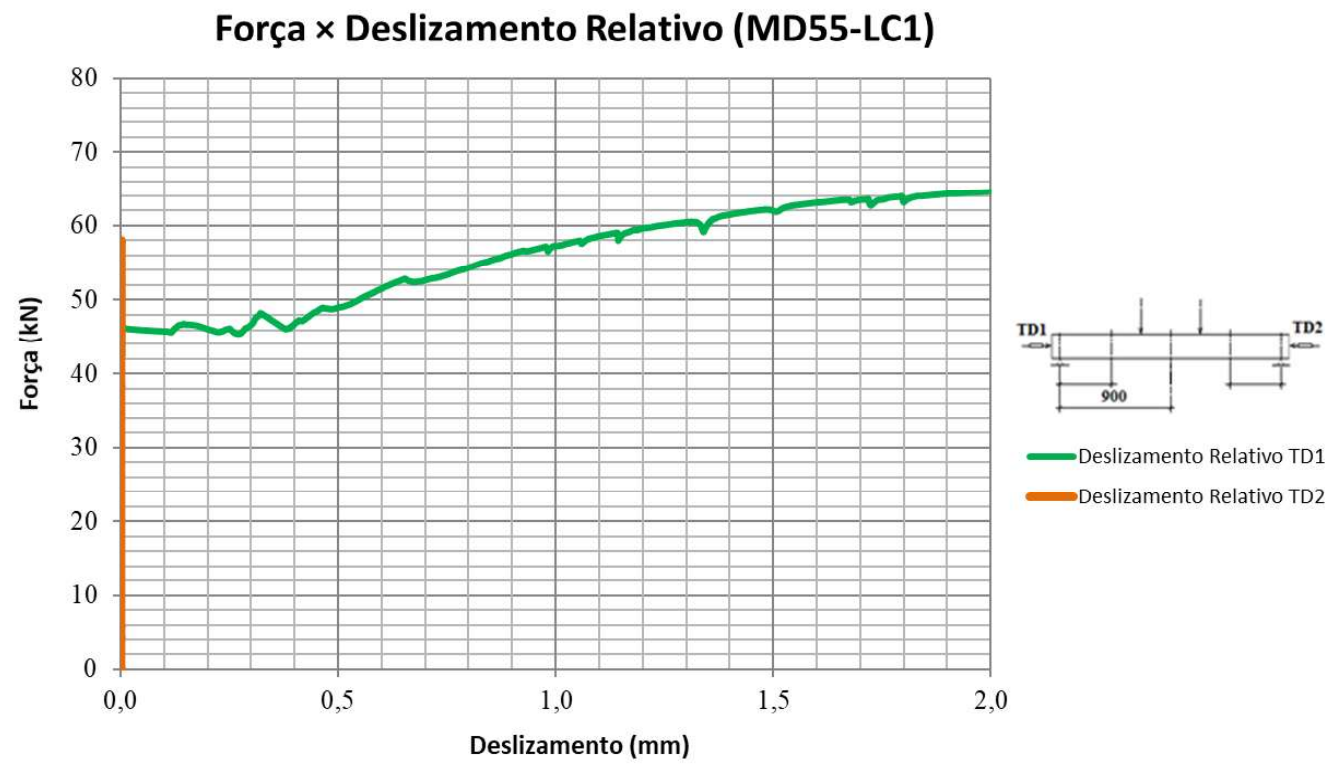

Fonte: Autora (2020)

Figura C. 30. Curva Força x Flecha do protótipo MD55-LC1.

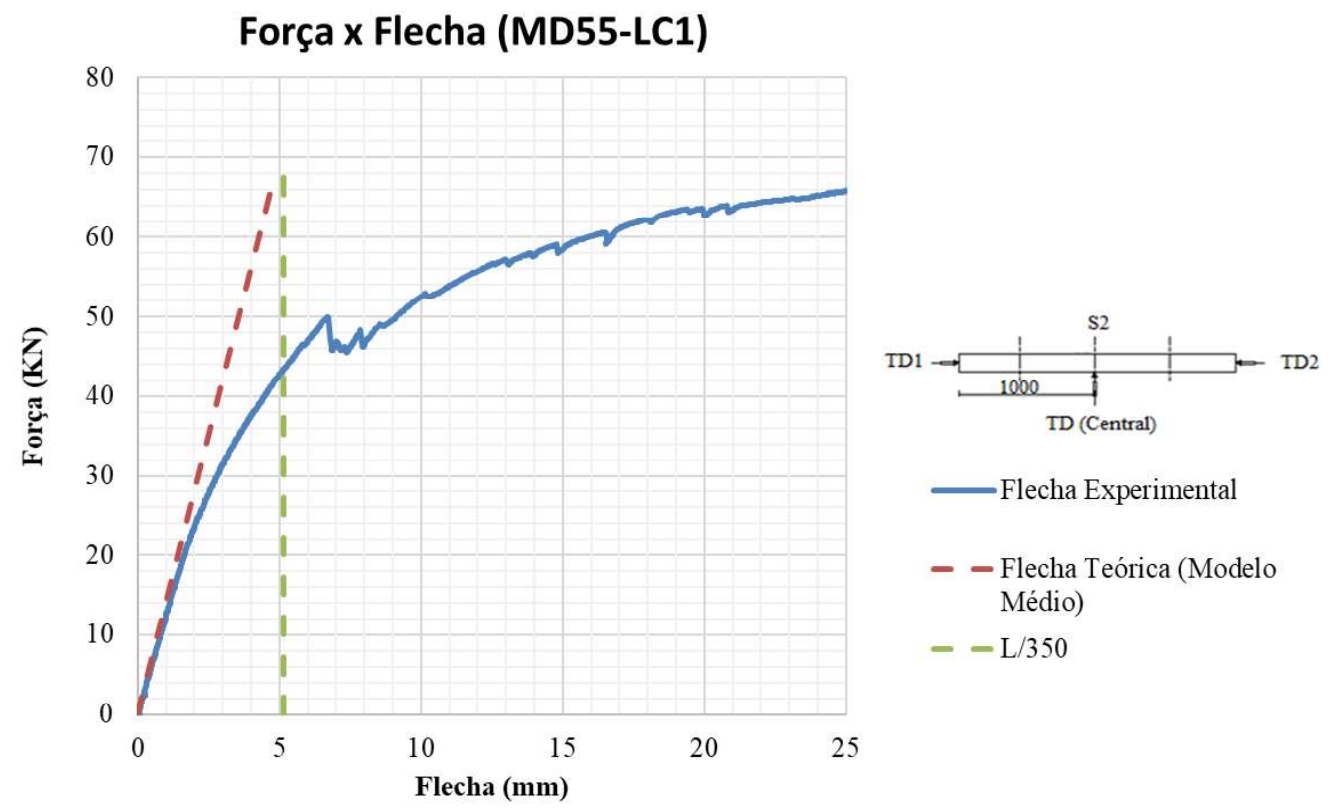

Fonte: Autora (2020) 
Figura C. 31. Curvas Força x Deformação no concreto na seção S1 do protótipo MD55-LC1.

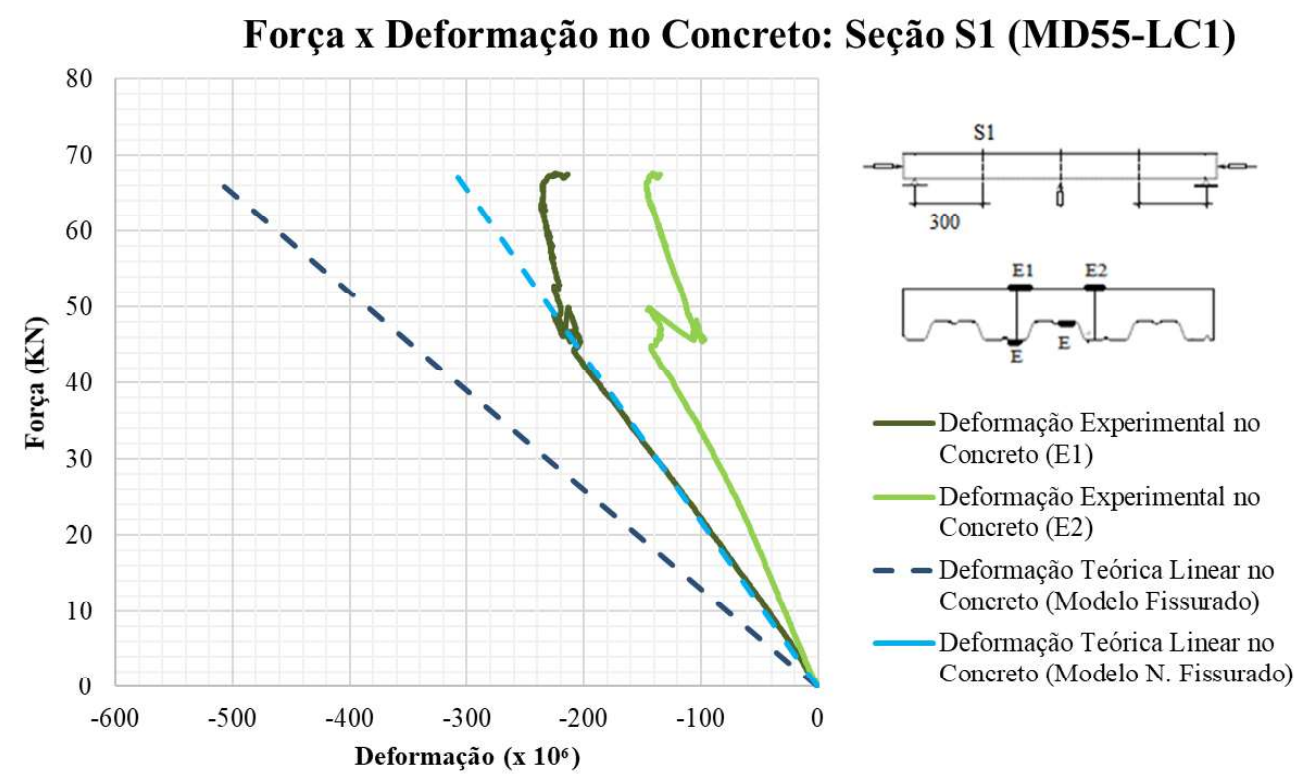

Fonte: Autora (2020)

Figura C. 32. Curvas Força x Deformação no concreto na seção S2 do protótipo MD55-LC1.

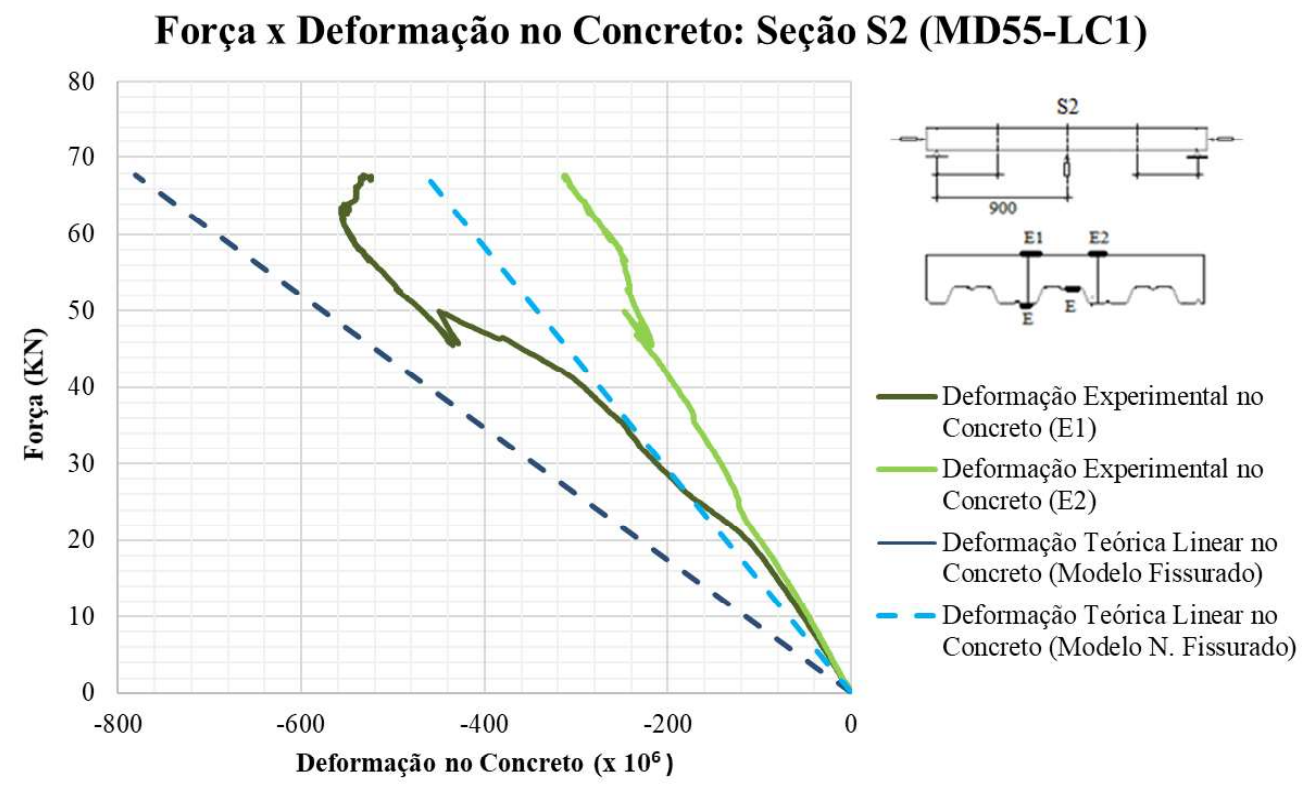

Fonte: Autora (2020) 
Figura C. 33. Curvas Força x Deformação no concreto na seção S3 do protótipo MD55-LC1.

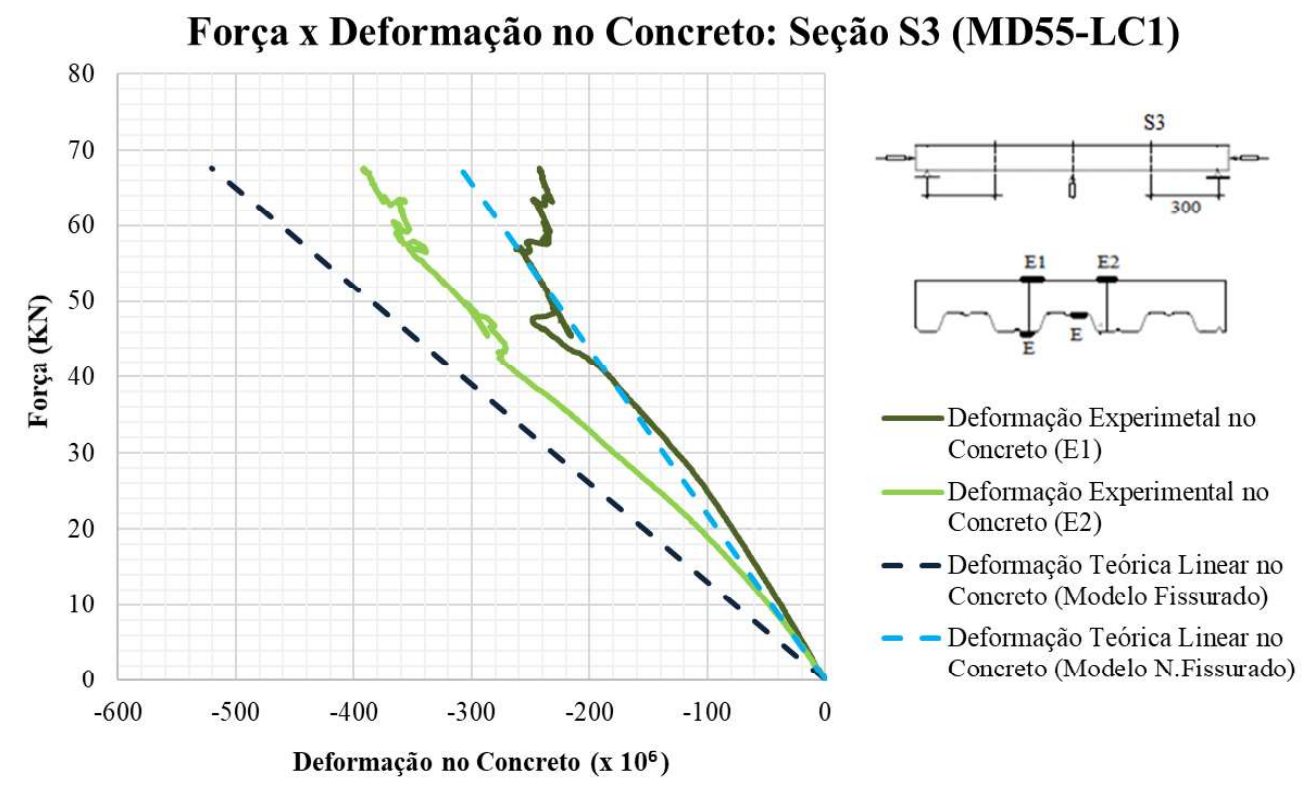

Fonte: Autora (2020)

Figura C. 34. Curvas Força x Deformação na fôrma de aço na seção S1 do protótipo MD55-LC1.

\section{Força x Deformação na Fôrma de Aço: Seção S1}

(MD55-LC1)
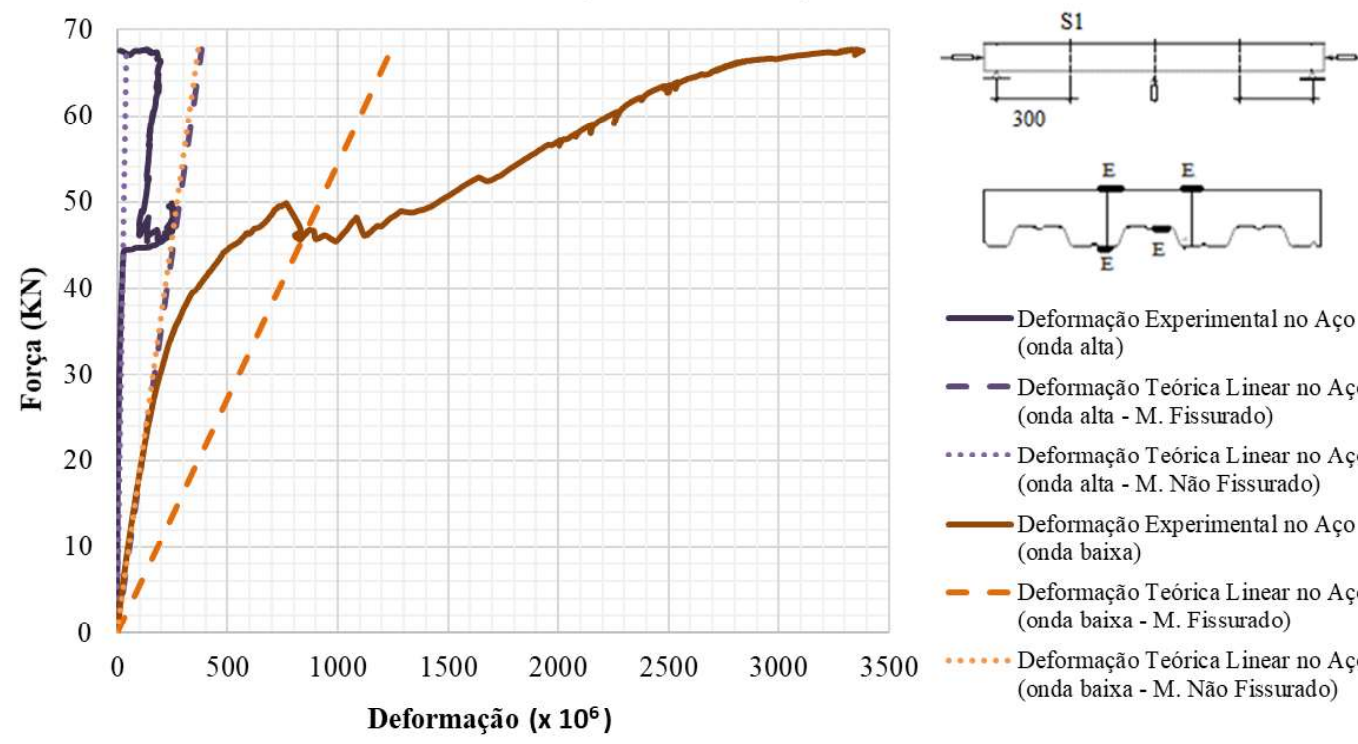

—Deformação Experimental no Aço (onda alta)

- Deformação Teórica Linear no Aço (onda alta - M. Fissurado)

..... Deformação Teórica Linear no Aço (onda alta - M. Não Fissurado)

—Deformação Experimental no Aço (onda baixa)

- Deformação Teórica Linear no Aço (onda baixa - M. Fissurado)

- Deformação Teórica Linear no Aço (onda baixa - M. Não Fissurado)

Fonte: Autora (2020) 
Figura C. 35. Curvas Força x Deformação na fôrma de aço na seção S2 do protótipo MD55-LC1.

\section{Força x Deformação na Fôrma de Aço Seção S2}

(MD55-LC1)
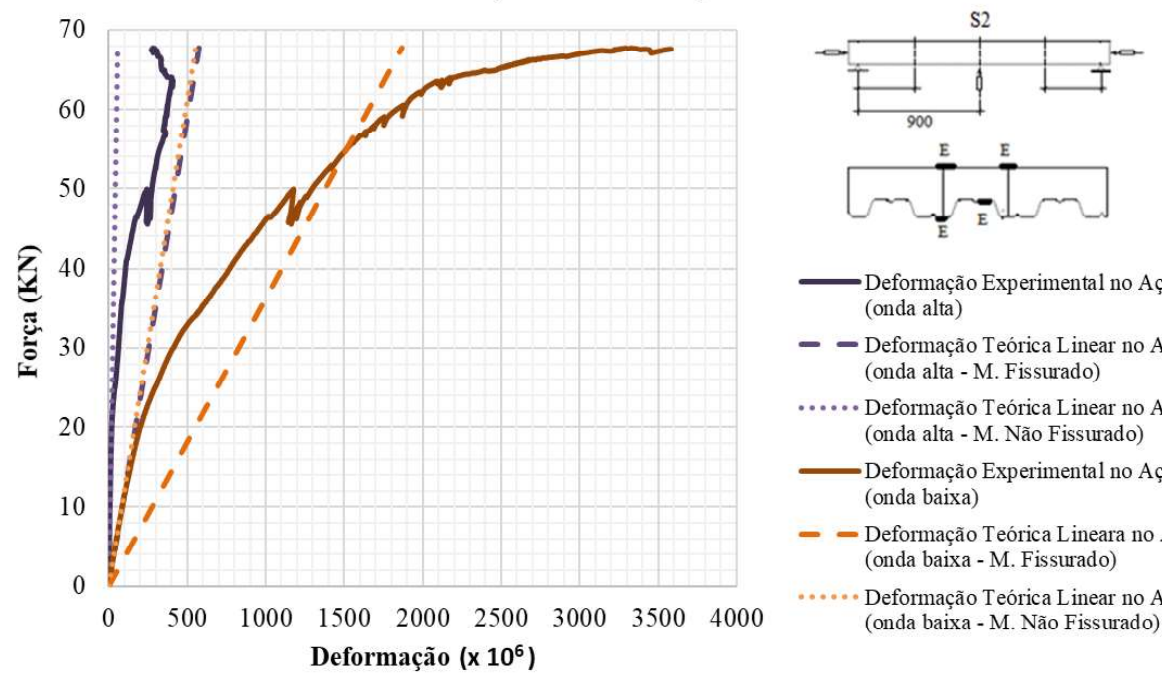

Deformação Experimental no Aço (onda alta)

- - Deformação Teórica Linear no Aço (onda alta - M. Fissurado)

- Deformação Teórica Linear no Aço (onda alta - M. Não Fissurado)

—Deformação Experimental no Aço (onda baixa)

- - Deformação Teórica Lineara no Aço (onda baixa - M. Fissurado)

...... Deformação Teórica Linear no Aço (onda baixa - M. Não Fissurado)

Fonte: Autora (2020)

Figura C. 36. Curvas Força x Deformação na fôrma de aço na seção S1 do protótipo MD55-LC1.

\section{Força x Deformação na Fôrma de Aço: Seção S3}

(MD55-LC1)
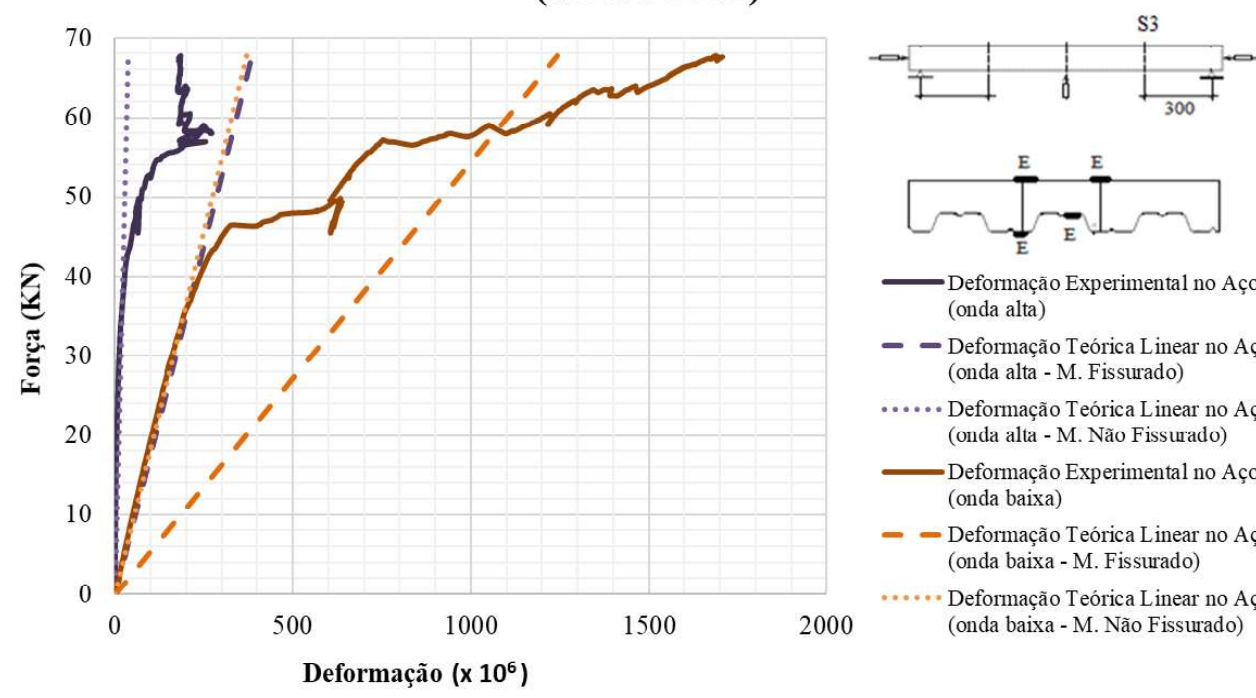

Deformaçao Experimental no Aço (onda alta)

- Deformação Teórica Linear no Aço (onda alta - M. Fissurado)

..... Deformação Teórica Linear no Aço (onda alta - M. Não Fissurado)

—Deformação Experimental no Aço (onda baixa)

- - Deformação Teórica Linear no Aço (onda baixa - M. Fissurado)

..... Deformação Teórica Linear no Aço (onda baixa - M. Não Fissurado)

Fonte: Autora (2020) 


\section{C.10 CURVAS DO PROTÓTIPO MD55-LC2}

Figura C. 37. Curva Força x Deslizamento Relativo do protótipo MD55-LC2.

\section{Força $\times$ Deslizamento Relativo (MD55-LC2)}

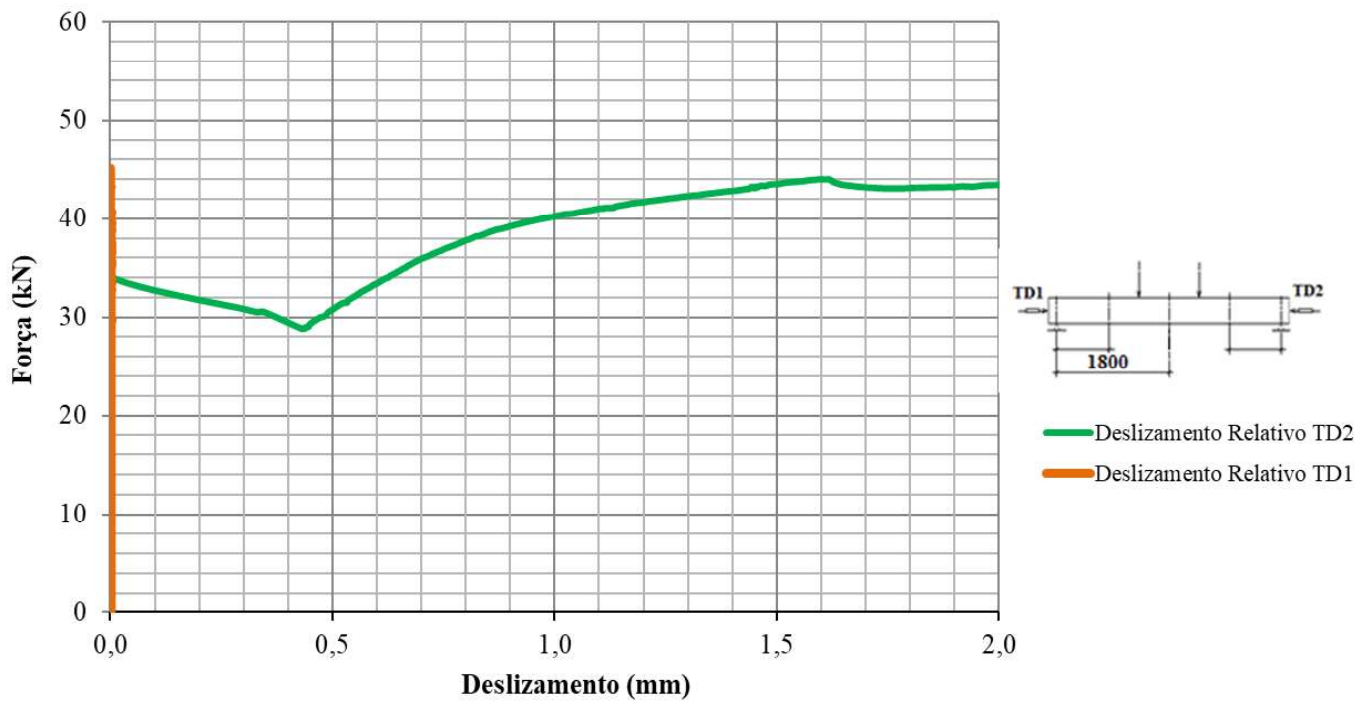

Fonte: Autora (2020)

Figura C. 38. Curva Força x Flecha do protótipo MD55-LC2.

Força x Flecha (MD55-LC2)

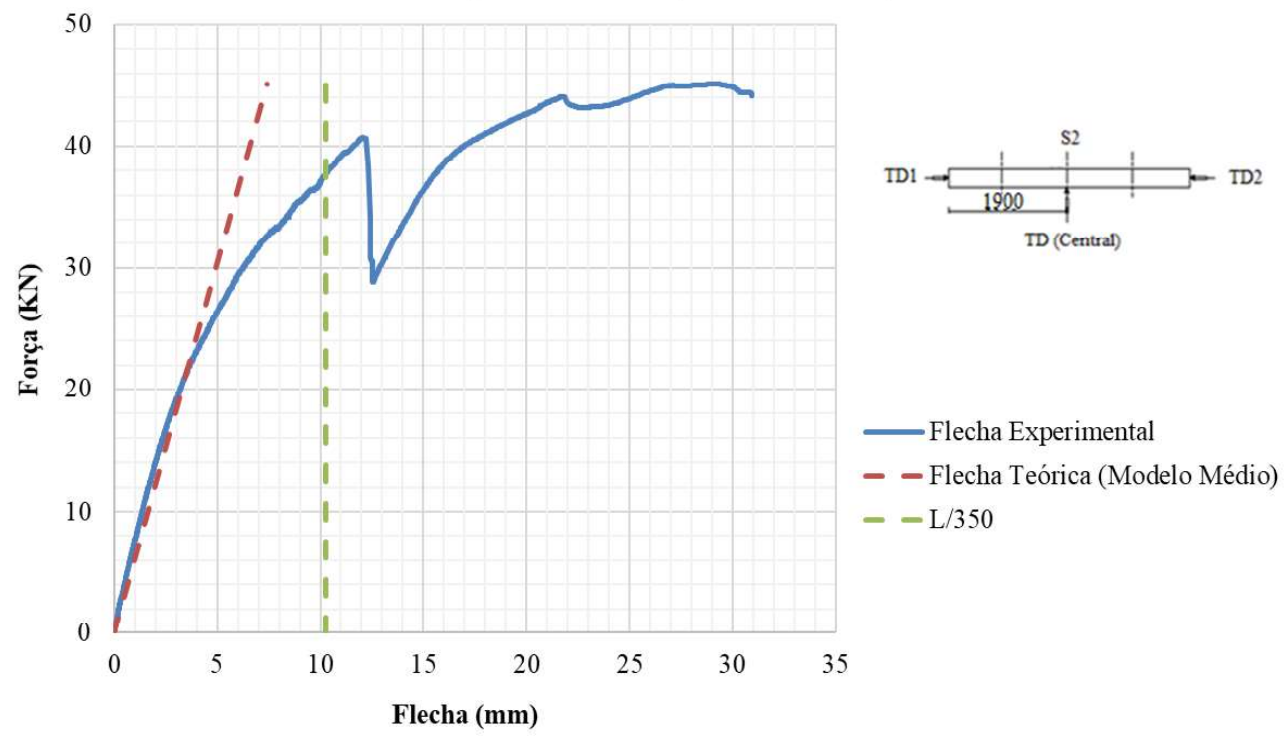

Fonte: Autora (2020) 
Figura C. 39. Curvas Força x Deformação no concreto na seção S1 do protótipo MD55-LC2.

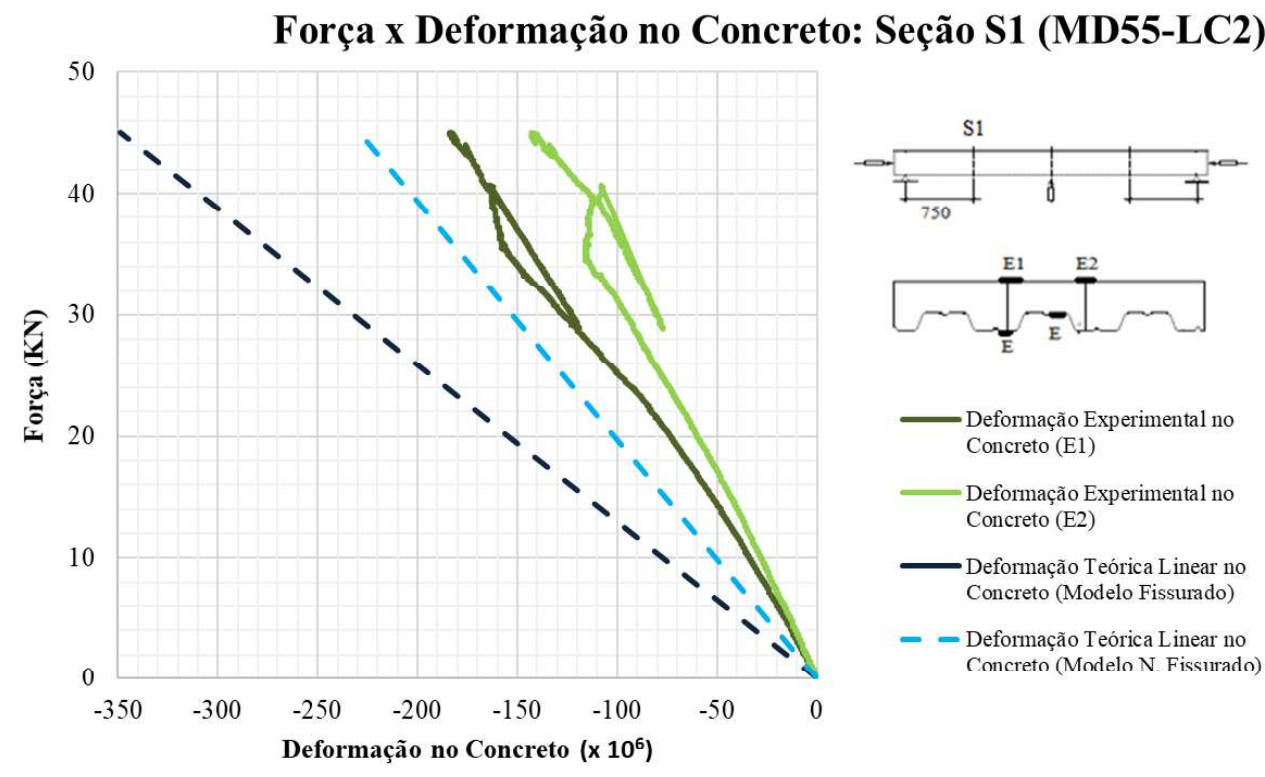

Fonte: Autora (2020)

Figura C. 40. Curvas Força x Deformação no concreto na seção S2 do protótipo MD55-LC2.

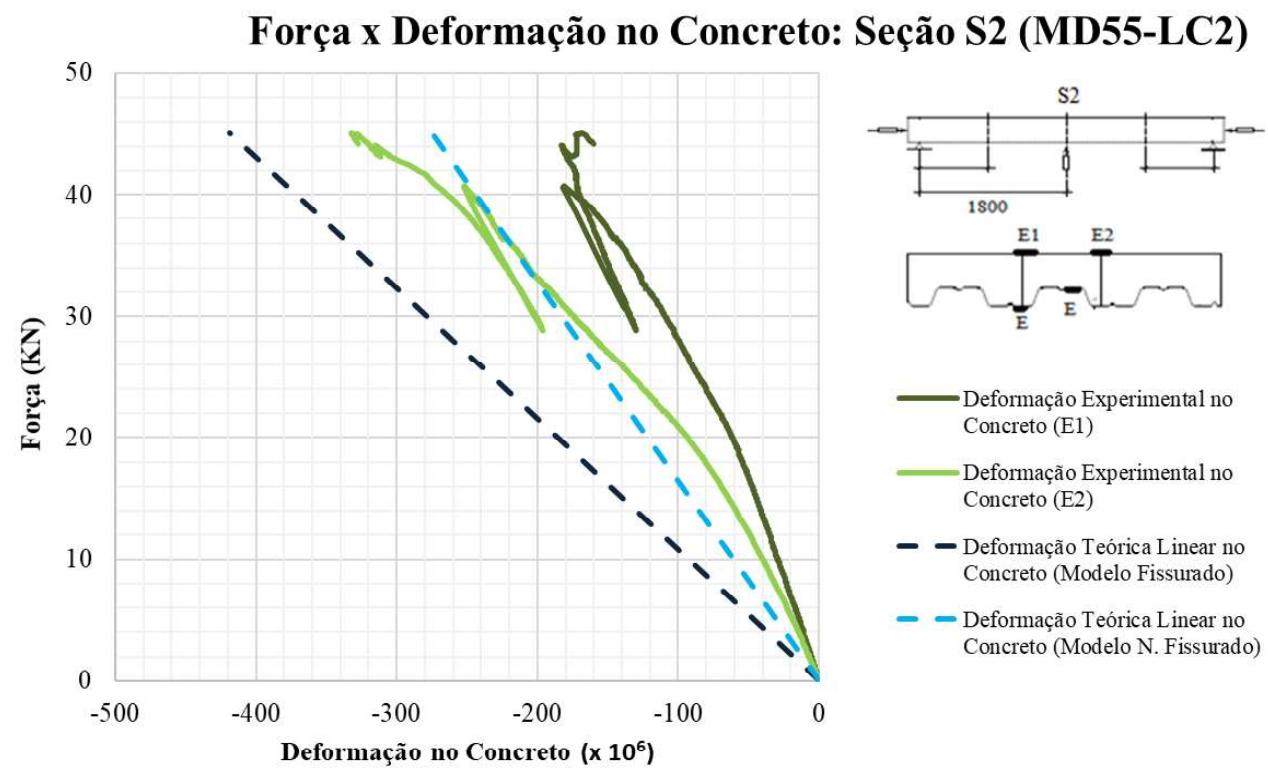

Fonte: Autora (2020) 
Figura C. 41. Curvas Força x Deformação no concreto na seção S3 do protótipo MD55-LC2.

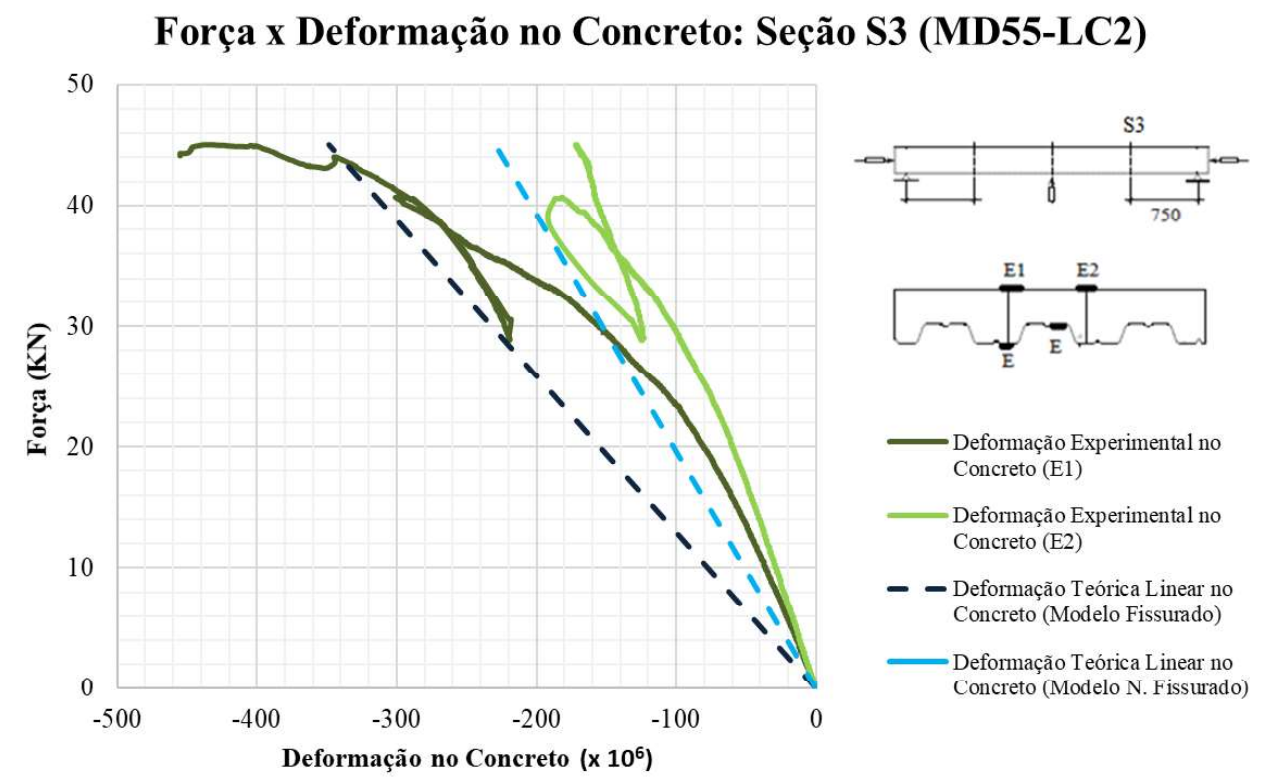

Fonte: Autora (2020)

Figura C. 42. Curvas Força x Deformação no fôrma de aço na seção S1 do protótipo MD55-LC2.

\section{Força x Deformação na Fôrma de Aço: Seção S1}

(MD55-LC2)
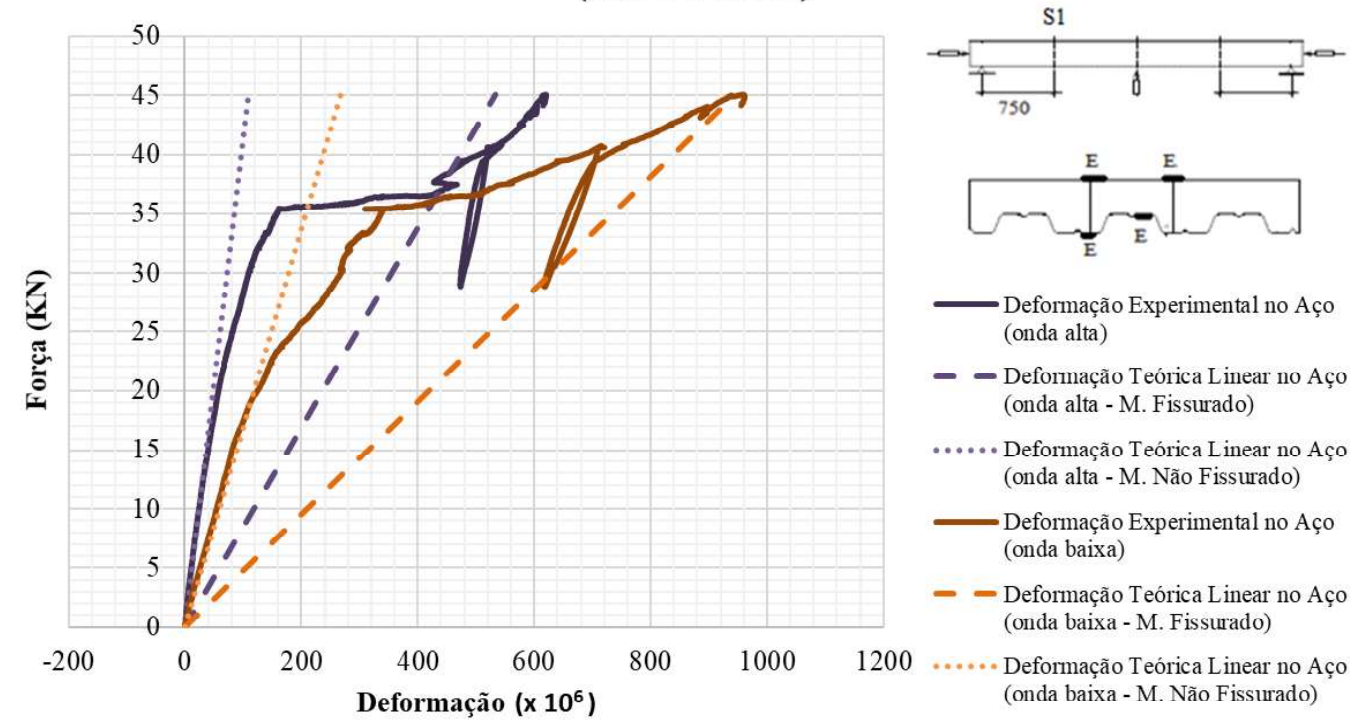

(onda alta - M. Fissurado)
(oformac̃o Teórica Line

-..... Deformação Teórica Linear no Aço (onda alta - M. Não Fissurado)

Deformação Experimental no Aço (onda baixa)

- - Deformação Teórica Linear no Aço (onda baixa - M. Fissurado)

- Deformação Teórica Linear no Aço (onda baixa - M. Não Fissurado)

Fonte: Autora (2020) 
Figura C. 43. Curvas Força x Deformação no fôrma de aço na seção S2 do protótipo MD55-LC2.

\section{Força x Deformação na Fôrma de Aço: Seção S2}

(MD55-LC2)
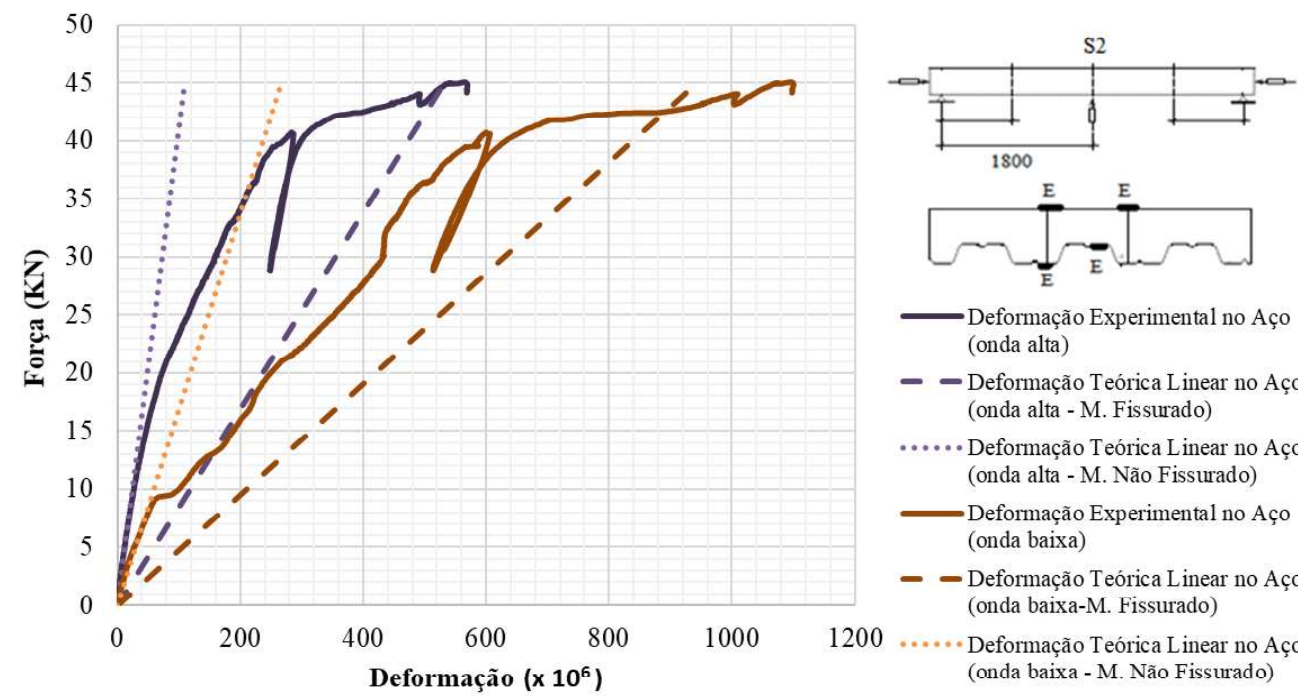

- Deformação Experimental no Aço (onda alta)

- - Deformação Teórica Linear no Aço (onda alta - M. Fissurado)

-..... Deformação Teórica Linear no Aço (onda alta - M. Não Fissurado)

Deformação Experimental no Aço (onda baixa)

- - Deformação Teórica Linear no Aço (onda baixa-M. Fissurado) .... Deformação Teórica Linear no Aço (onda baixa - M. Não Fissurado)

Fonte: Autora (2020)

Figura C. 44. Curvas Força x Deformação no fôrma de aço na seção S3 do protótipo MD55-LC2.

\section{Força x Deformação na Fôrma de Aço: Seção S3}

(MD55-LC2)
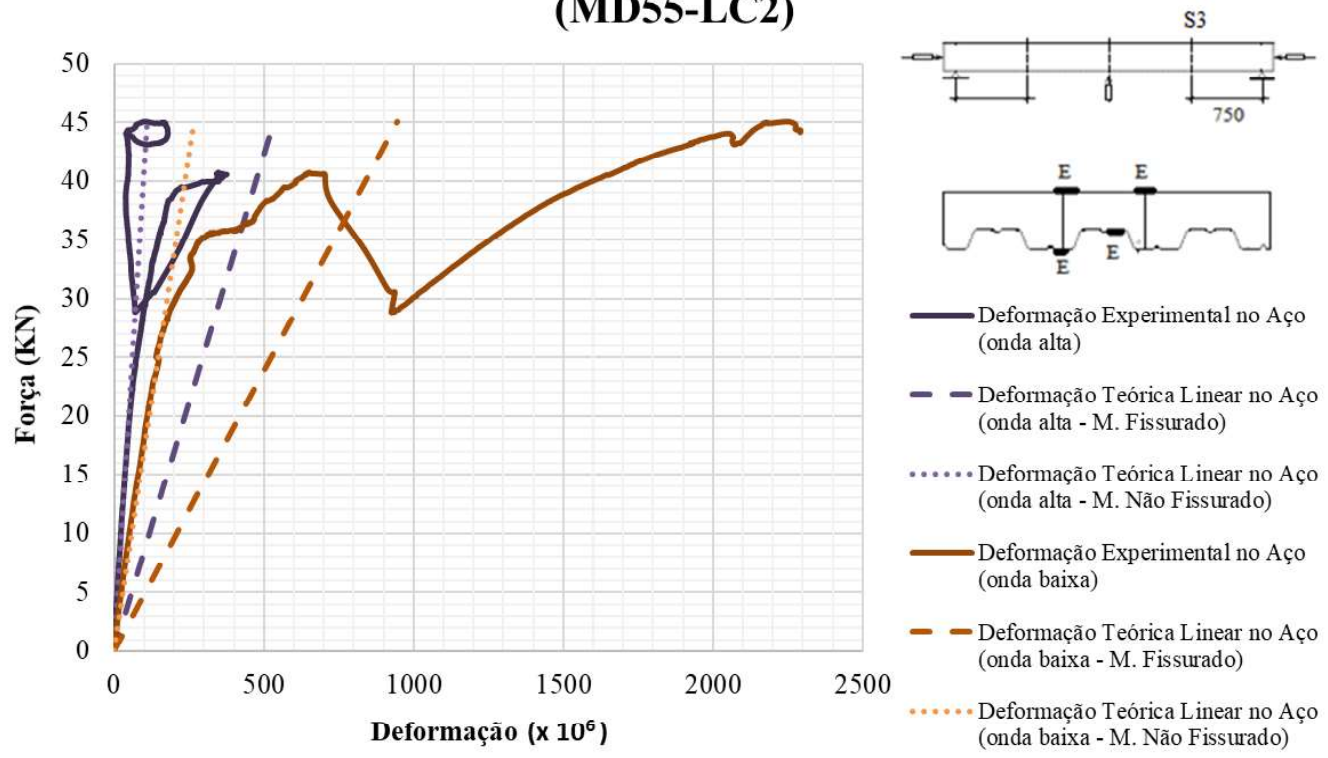

Fonte: Autora (2020) 